FLÁVIO MARQUES PROL

\title{
DIREITO E MACROECONOMIA: UM ESTUDO DO REGIME JURÍDICO DA POLÍTICA FISCAL NO BRASIL
}

ORIENTADOR: PROFESSOR JEAN PAUL CABRAL VEIGA DA ROCHA

\author{
Dissertação de Mestrado
}

Faculdade de Direito da Universidade de São Paulo

SÃo Paulo

2014 


\title{
FLÁVIO MARQUES PROL
}

\section{DIREITO E MACROECONOMIA: UM ESTUDO DO REGIME JURÍDICO DA POLÍTICA FISCAL NO BRASIL}

\begin{abstract}
Dissertação apresentada à Faculdade de Direito da Universidade de São Paulo, sob a orientação do Professor Jean Paul Cabral Veiga da Rocha, como requisito parcial para a obtenção do título de Mestre, na área de concentração de Filosofia e Teoria Geral do Direito.
\end{abstract}

Faculdade de Direito da Universidade de São Paulo

São Paulo 


\title{
FLÁVIO MARQUES PROL
}

\section{DIREITO E MACROECONOMIA: UM ESTUDO DO REGIME JURÍDICO DA POLÍTICA FISCAL NO BRASIL}

\begin{abstract}
Dissertação apresentada à Faculdade de Direito da Universidade de São Paulo, sob a orientação do Professor Jean Paul Cabral Veiga da Rocha, como requisito parcial para a obtenção do título de Mestre, na área de concentração de Filosofia e Teoria Geral do Direito.
\end{abstract}

Aprovada em:

Banca examinadora:

Prof.:

Julgamento:

Prof.:

Julgamento:

Prof.:

Julgamento:
Instituição

Assinatura:

Instituição

Assinatura:

Instituição

Assinatura: 


\section{AGRADECIMENTOS}

Ao longo desta pesquisa, incomodei muitas pessoas com discussões sobre suas principais ideias.

Em primeiro lugar, gostaria de agradecer ao meu orientador, professor Jean Paul. Desde os primeiros contatos, no Programa de Educação Tutorial, sua orientação tem sido fundamental para meu desenvolvimento intelectual. Nossas interações ao longo de todos esses anos são um verdadeiro estímulo para a tentativa de desenvolver uma reflexão motivada sobre as principais questões da democracia brasileira.

O desenho do projeto desta pesquisa se consolidou após a realização da disciplina de pós-graduação "Direito e Desenvolvimento", ministrada pelo professor Diogo Coutinho, no segundo semestre de 2012. Agradeço ainda aos seus comentários e os da professora Mariana Mota Prado, apresentados durante a conferência CGLAD The conference on Global Law and Development -, em junho de 2013, quando tive a oportunidade de discutir uma primeira versão do projeto. Agradeço também a Pedro Fortes, Alberto Barbosa Jr. e Raquel Pimenta.

As palavras de incentivo e orientação dos professores Mário Schapiro e Diogo Coutinho, além do professor Jean Paul, na banca de qualificação, também foram essenciais. Elas orientaram o aprimoramento do projeto e me apoiaram para seguir em frente.

No segundo semestre de 2013 e no primeiro semestre de 2014, tive a oportunidade única de aprofundar esta pesquisa no exterior, por meio do Programa Fox Fellowship, que a Universidade de Yale mantém com a Universidade de São Paulo. Agradeço a Joseph Fox e sua família por terem criado esse programa.

Durante a minha estadia no exterior, pude conviver com um grupo de pesquisadoras e pesquisadores, dos mais diferentes campos, que contribuíram não só com a pesquisa, mas também com uma acolhida familiar e calorosa em um rigoroso inverno. Agradeço a Aaron Bartels-Swindells, Marisol Celorio, Ashkhen Kazaryan, Mayumi Shimizu, Philile Nonhlanhla Mbatha, Salvador Santino Regilme Jr., Lwando Scott, Anastasia, Idan Barir, Asaf Ziderman, Aysen Eren, Hannah Ishikawa, Amrita Nandy, Yundi You, Siming Yu, Elise Roumeas, Nina Di Bosco, Francesca Amerio, Michael Rom, Roma Zinigrad, Gisela Mation, Thomaz Pereira, Juliana Pondé e Julia Muravnik. Agradeço ainda ao bibliotecário David Gary. O agradecimento também se estende aos professores Julia Adams e Jerry Mashaw, os quais gentilmente se 
dispuseram a criticar versões resumidas do projeto. Devo um agradecimento especial a Michael Blaakman, que discutiu por diversas vezes versões em inglês do projeto desta pesquisa e de artigos que reproduziram suas principais ideias.

Uma versão resumida e apresentada em forma de artigo dos capítulos 2 e 4 foi discutida na 50 Conferência Anual da Associação Law and Society e na conferência realizada pelo Programa Fox Fellowship. Agradeço os comentários críticos de Fernando Rugitsky, Ivan de Franco, Iagê Miola, Pedro de Paula, Osny da Silva Filho, Gisela Mation, Rafael Zanatta, Francisco Brito Cruz, Thomaz Pereira, Juliana Pondé, Elise Roumeas, Nina Di Bosco, Philile Mbatha, Idan Barir, Mayumi Shimizu, Aldair Carlos Rodrigues e Daniel Oliveira.

Uma versão do capítulo 3 foi discutida na conferência da Sociedade de Direito Econômico Internacional (3rd Conference of the Postgraduate and Early Professionals/Academics Network of the Society of International Economic Law), realizada na Escola de Direito da Fundação Getúlio Vargas, na qual recebi comentários extremamente valiosos do professor Bruno Salama, da professora Camila Duran e de Gabriel Lochagin.

Agradeço por todos os comentários que recebi ao longo da pesquisa por parte do professor Ben Cashore. Ben leu e criticou detalhadamente uma versão resumida do projeto e cada uma das versões dos textos apresentadas nessas conferências.

Devo também um agradecimento a Pedro Salomon, quem revisou atentamente uma das últimas versões desta dissertação, e a Humberto Caetano de Sousa e Adonis Tarallo, servidores públicos do Ministério da Justiça, que me auxiliaram no levantamento dos materiais de discussões legislativas e jurisprudenciais.

Tenho uma dívida especial com José Rodrigo Rodriguez, quem representa para mim não somente um dos melhores exemplos de intelectual engajado com um projeto democrático contrário a qualquer tipo de opressão, como um verdadeiro amigo que escuta pacientemente minhas inquietações acadêmicas. Foi ele também que me convidou a integrar o Núcleo de Direito e Democracia do Centro Brasileiro de Análise e Planejamento, espaço no qual tive a oportunidade de vivenciar discussões acadêmicas de altíssimo nível. Agradeço a todos os colegas do Núcleo, em especial a Marcos Nobre e a Ricardo Terra, por terem me acolhido.

No primeiro ano e no último semestre de elaboração desta pesquisa, compartilhei o trabalho acadêmico com a advocacia e com o serviço público, 
respectivamente. Agradeço a Luiz Armando Badin e a Marivaldo de Castro Pereira pela compreensão e pelo apoio.

Agradeço especialmente a compreensão dos amigos e das amigas nesses três anos de pouco convívio. Agradeço a Camila Rolemberg, Carolina Reinach, Andrea Cruz, Ana Carolina Fama, Bianca Tavolari, Bernardo Mendonça e Henrique Venturelli, além de todos os meus amigos de Santos.

Agradeço ainda a minha família, em particular ao meu pai e ao meu irmão, que nunca deixaram de me apoiar durante o percurso, mesmo quando estive ausente. Por fim, serei eternamente grato à Flávia Annenberg. A paciência com que lê, escuta, comenta e critica cada uma das minhas ideias é um exemplo único de dedicação, tolerância e sabedoria. Seu abraço e seu carinho nas horas mais difíceis foram imprescindíveis para a conclusão desta dissertação. À minha companheira, muito obrigado. 


\section{RESUMO}

A presente dissertação tem o objetivo de analisar os papéis do direito para a política fiscal no Brasil, a partir de um estudo sobre o que esta pesquisa chama de "regime jurídico da política fiscal". Interpreta-se esse regime jurídico como o conjunto de princípios e regras que regulam a gestão do gasto e do endividamento públicos. A pesquisa busca combinar uma análise das funções do regime jurídico para objetivos de política fiscal com um estudo sobre o papel do direito para a própria legitimação social desses objetivos. Assim, argumenta-se que o regime jurídico da política fiscal no Brasil foi reformado na década de 1990 com o propósito de promover a agenda do ajuste fiscal e da sustentabilidade da dívida pública na gestão da política fiscal. Essa reforma implicou mudanças significativas em quatro âmbitos: prerrogativas fiscais foram centralizadas na União, em detrimento de estados e municípios; houve centralização do poder fiscal no Executivo, em relação ao Legislativo; foram instituídos limites legais à gestão da política fiscal, incluindo limitações com despesas com pessoal e com endividamento público; e foram criados novos mecanismos de transparência e prestação de contas da política fiscal. Ao contrário do que normalmente se argumenta na literatura, que enfatiza os fatores domésticos que resultaram na reforma do regime, esta pesquisa propõe uma interpretação que combina fatores domésticos com influências internacionais na explicação das determinantes da reforma. O último capítulo analisa os efeitos da implantação do novo regime jurídico para a política fiscal até o ano de 2014, os quais permitem perceber que, embora as regras e os princípios jurídicos tenham efetivamente reduzido a margem de manobra fiscal de estados e municípios, centralizado competências fiscais no Executivo e criado novos mecanismos de transparência e prestação de contas da política fiscal, é possível defender que ainda existe um considerável espaço de discricionariedade na definição e na gestão da política fiscal no âmbito do Poder Executivo federal.

Palavras-chave: "política fiscal"; "direito e macroeconomia"; "regime jurídico da política fiscal"; "instituições da política fiscal"; "regras fiscais". 


\begin{abstract}
This dissertation aims at analyzing the roles of law in fiscal policy in Brazil, from the study of what this research calls "legal regime of fiscal policy". The legal regime of fiscal policy comprehends legal principles and rules that regulate the management of public expenditure and public debt. The research tries to combine an analysis of the functions of the legal regime for fiscal policy goals with a perspective on the role of law to their democratic legitimacy. It argues that the legal regime of fiscal policy in Brazil was reformed in the 1990s aiming at promoting the fiscal adjustment and public debt sustainability agenda. This reform provoked substantive changes in four different domains: fiscal policy decisions were concentrated in the Union, in comparison with states and municipalities; fiscal power was centralized in the Executive vis a vis the Legislative; fiscal rules establishing legal limits to fiscal policy management were implemented, including limits to public indebtedness and expenditures with payroll; new mechanisms of transparency and accountability were created. This research also advances an interpretation about the relationship between domestic elements and international influences that resulted in the legal reform, while the literature usually focuses on the narrative about the domestic elements. The last part of the dissertation analyzes the implementation of the new legal regime for fiscal policy up to 2014. The research claims that, although legal principles and rules reduced the room for maneuver for fiscal decisions by states and municipalities, centralized fiscal power in the Executive and created new mechanisms of transparency and accountability, it is possible to argue that there is still some discretion for the management of the fiscal policy in the federal Executive.
\end{abstract}

Key words: Fiscal policy; law and macroeconomics; legal regime of fiscal policy; fiscal policy institutions; fiscal rules. 


\section{LISTA DE TABELAS}

Tabela 1: Regras e princípios jurídicos para a política fiscal na década de 1980. .70

Tabela 2: Histórico normativo da desvinculação de receitas da União. 133

\section{LISTA DE GRÁFICOS}

Gráfico 1 - Comparação entre Dívida Consolidada Líquida e Receita Corrente Líquida por

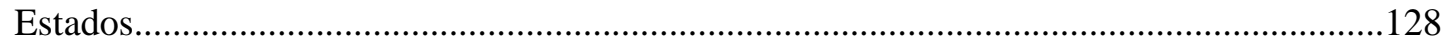

Gráfico 2 - Superávit Primário e Metas de Superávit: 1991-2013 _......................................136

Gráfico 3 - Exceções ao cálculo de superávit primário: 2006-2013 …..................................142

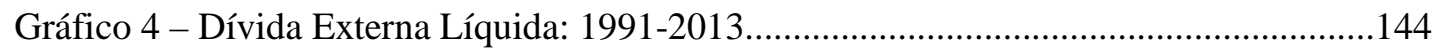




\section{LISTA DE SIGLAS E ABREVIATURAS}

ADI

ARO

ATRICON

$\mathrm{BB}$

$\mathrm{BCB}$

BNDES

CEPAL

CF

CGU

$\mathrm{CMN}$

COMOR

CONAMP

DCD

DCN

DRU

e-SIC

FBO

FEF

FGV

FMI

FSP

IBGE

IBRE

ICMS

INESC

INPC
Ação Direta de Inconstitucionalidade

Antecipação de receita orçamentária

Associação dos membros dos Tribunais de Contas do Brasil

Banco do Brasil

Banco Central do Brasil

Banco Nacional de Desenvolvimento Econômico e Social

Comissão Econômica das Nações Unidas para a América Latina

Constituição Federal

Controladoria-Geral da União

Conselho Monetário Nacional

Comitê interministerial de acompanhamento da execução dos orçamentos públicos

Associação Nacional dos Membros do Ministério Público

Diário da Câmara dos Deputados

Diário do Congresso Nacional

Desvinculação de receitas da União

Sistema eletrônico do serviço de informação ao Cidadão

Fórum Brasil do Orçamento

Fundo de Estabilização Fiscal

Fundação Getúlio Vargas

Fundo Monetário Internacional

Folha de São Paulo

Instituto Brasileiro de Geografia e Estatística

Instituto Brasileiro de Economia

Imposto sobre circulação de mercadorias e serviços

Instituto de Estudos Socioeconômicos

Índice Nacional de Preços ao Consumidor 


\begin{tabular}{|c|c|}
\hline IPEA & Instituto de Pesquisa Econômica Aplicada \\
\hline LCF & Lei de Crimes Fiscais \\
\hline LDO & Lei de Diretrizes Orçamentárias \\
\hline LOA & Lei Orçamentária Anual \\
\hline LRF & Lei de Responsabilidade Fiscal \\
\hline MF & Ministério da Fazenda \\
\hline OCDE & Organização para Cooperação e Desenvolvimento Econômico \\
\hline OPI & Orçamento Plurianual de Investimentos \\
\hline PAC & Programa de Aceleração do Crescimento \\
\hline PCdoB & Partido Comunista do Brasil \\
\hline PEF & Programa de Estabilidade Fiscal \\
\hline PFL & Partido da Frente Liberal \\
\hline PIB & Produto Interno Bruto \\
\hline PLP & Projeto de Lei Complementar \\
\hline PMDB & Partido do Movimento Democrático Brasileiro \\
\hline PPA & Plano Plurianual \\
\hline PROES & $\begin{array}{l}\text { Programa de Incentivo à Redução do Setor Público Estadual na } \\
\text { Atividade Bancária }\end{array}$ \\
\hline PSB & Partido Socialista Brasileiro \\
\hline PSDB & Partido da Social Democracia Brasileira \\
\hline PT & Partido dos Trabalhadores \\
\hline PTB & Partido Trabalhista Brasileiro \\
\hline RSF & Resolução do Senado Federal \\
\hline SIAFI & Sistema Integrado de Administração Financeira do Governo Federal \\
\hline STF & Supremo Tribunal Federal \\
\hline STN & Secretaria do Tesouro Nacional \\
\hline SUMOC & Superintendência da Moeda e do Crédito \\
\hline TCU & Tribunal de Contas da União \\
\hline
\end{tabular}




\section{SUMÁRIO}

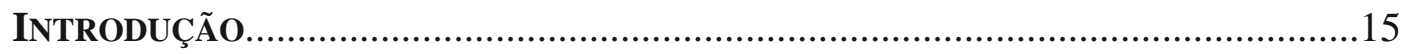

A MACROECONOMIA PARA ALÉM DA CIÊNCIA ECONÔMICA: DIREITO E

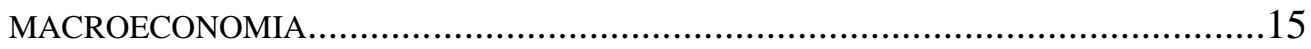

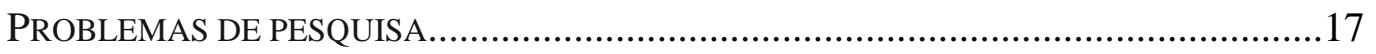

ESTRUTURAÇÃO DO TRABALHO E OBSERVAÇÕES METODOLÓGICAS.........................20

1. Direito E MACROECONOMia: UM ESTUdo DA POLÍtica FISCAL EM UMA

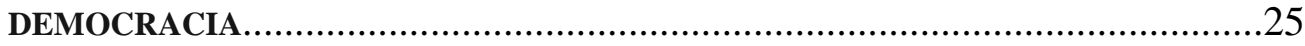

1.1 DisSENSO NA LITERATURA ECONÔMICA SOBRE POLÍTICA

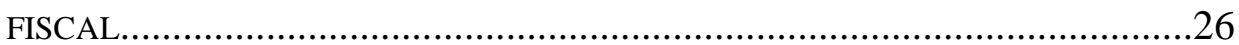

1.2 REGRAS, INSTITUIÇÕES E POLÍTICA FISCAL.....................................................33

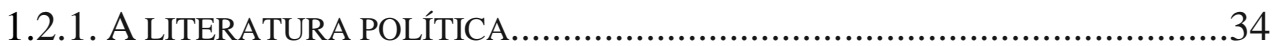

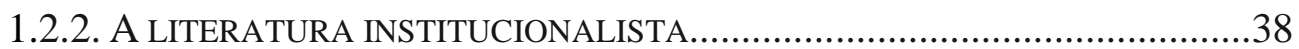

1.3 DIREITO DA MACROECONOMIA EM UMA DEMOCRACIA...................................44

2. UM NOVO REGIME JURÍDICO DA POLÍTICA FISCAL NO BRASIL........................... 51

2.1 AS REFORMAS LEGAIS E INSTITUCIONAIS DA POLÍTICA FISCAL NA DÉCADA DE 1980: CRIAÇÃO SIMULTÂNEA DAS AUTORIDADES FISCAL E MONETÁRIA.............52

2.1.1. O DESENHO DAS FINANÇAS PÚBLICAS NO INÍCIO DA DÉCADA DE 1980....53

2.1.2. DO DIAGNÓSTICO À REFORMA: O EXECUTIVO NA REFORMA DAS FINANÇAS PÚBLICAS.

2.1.3. A CONSTITUINTE E O LEGISLATIVO NA REFORMA.

.63

2.1.4. UM RESUMO DA REFORMA DAS FINANÇAS PÚBLICAS NA DÉCADA DE 1980

2.2 UM NOVO REGIME JURÍDICO DA POLÍTICA FISCAL E A AGENDA DO AJUSTE FISCAL E DA SUSTENTABILIDADE DA DÍVIDA PÚBLICA............................................72

2.2.1. REGRAS E PRINCÍPIOS CENTRALIZANDO O PODER FISCAL NA UNIÃO.........75

2.2.2. REgRAS E PRINCÍPIOS CENTRALIZANDO O PODER FISCAL NO EXECUTIVO. 78

2.2.3. REGRAS E PRINCÍPIOS DEFININDO LIMITES PARA A POLÍTICA FISCAL.........80 
2.2.4. REGRAS E PRINCÍPIOS DE TRANSPARÊNCIA E PRESTAÇÃO DE CONTAS DA POLÍTICA FISCAL

2.3 AS DETERMINANTES DO NOVO REGIME E A INDETERMINAÇÃO DO DIREITO 84

3. A REFORMA do REgIME JURídico dA POLÍtiCA FISCAL NO CONTEXTO DO AJUSTE: FATORES DOMÉSTICOS E INFLUÊNCIAS INTERNACIONAIS. .87

3.1 A CENTRALIDADE DE FATORES DOMÉSTICOS NA APROVAÇÃO DO REGIME. 92

3.2 VETORES DE INFLUÊNCIAS INTERNACIONAIS NA REFORMA DO REGIME JURÍDICO DA POLÍTICA FISCAL 101

3.2.1 CRISE DOS PAÍSES EMERGENTES. 101

3.2.2 EXPERIÊNCIAS INTERNACIONAIS COM REGRAS FISCAIS COMO PADRÃO DE EXCELÊNCIA 105

3.2.3 A LEI DE RESPONSABILIDADE FISCAL COMO UMA REFORMA ESTRUTURAL: O EFEITO DE SINALIZAÇÃO. 106

3.2.4 O DESEJO DOMÉSTICO PELO ACORDO: ALAVANCANDO OS ESFORÇOS DO GOVERNO FEDERAL NA APROVAÇÃO DE REFORMAS ESTRUTURAIS......113

3.3 COMBINANDO “CONSENSO” DOMÉSTICO COM INFLUÊNCIA INTERNACIONAL...116

4. A IMPLEMENTAÇÃO DO REGIME JURÍDICO DA POLÍTICA FISCAL 120

4.1 Centralização DA POLÍtica Fiscal: MudançAs DA RELAÇÃo FEDERATIVA 123

4.2 CENTRALIZAÇÃO DA POLÍTICA FISCAL: PREDOMINÂNCIA DO EXECUTIVO. 130

4.3 A DISCRICIONARIEDADE DA GESTÃO DA POLÍTICA FISCAL DO SETOR PÚBLICO CONSOLIDADO. 135

4.4 NOVOS MECANISMOS DE TRANSPARÊNCIA E DE PRESTAÇÃO DE CONTAS. 147

CONCLUSÃO: LEGITIMIDADE DEMOCRÁTICA, DIREITO E POLÍTICA FISCAL .160

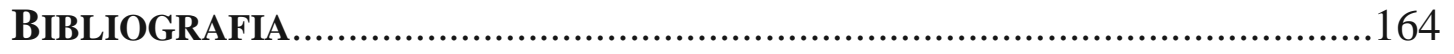
ANEXOS .180 
Suponho que os que estão fortemente apegados àquilo que chamarei de "teoria clássica" flutuarão entre a crença de que estou completamente errado e a crença de que não estou dizendo nada de novo. Cabe a outros determinar se uma dessas duas ou ainda uma terceira alternativa está correta. [...] A esta altura da disputa, o público em geral, embora seja bemvindo ao debate, apenas observará de fora uma tentativa de um economista no sentido de resolver as profundas divergências de opinião entre seus colegas economistas que quase chegaram a destruir a influência prática da teoria econômica e que continuarão, até que sejam resolvidas, a ter esse efeito (John Maynard Keynes, no prefácio do seu livro A Teoria Geral do Emprego, do Juro e da Moeda [1935]. Tradução de Mário R. da Cruz. São Paulo: Abril Cultural, 1983).

It is of vital importance for everybody who believes in the values of democracy that an investigation be made as to whether state capitalism can be brought under democratic control. The social as well as the moral problem with which the democracies are confronted has been formulated as follows: '...How can we get effective use of our resources, yet at the same time preserve the underlying values in our tradition of liberty and democracy? How can we employ our unemployed, how can we use our plant and equipment to the full, how can we take advantage of the best modern technology, yet, in all this make the individual source of value and individual fulfillment in society the basic objective? How can we obtain effective organization of resources, yet at the same time retain the maximum freedom of individual action'? (Friedrich Pollock, State Capitalism: its possibilities and limitations. Studies in Philosophy and Social Sciences vol. IX. Frankfurt: Universität Frankfurt am Main. Institut für Sozialforschung, 1941) 


\section{Introdução}

\section{A macroeconomia para além da ciência econômica: direito e macroeconomia}

Políticas macroeconômicas estão entre os principais instrumentos dos estados modernos para gestão de suas economias. Os estados utilizam essas políticas para influenciar a renda nacional, a taxa de crescimento da economia, os índices de inflação de preços, o nível de desemprego, o endividamento público, entre outros indicadores econômicos. Ao longo do século XX, a importância dessas políticas se tornou reconhecida. No início do século XXI, após a recente crise econômica global, seu lugar no topo das prioridades políticas da maior parte dos países se tornou inquestionável.

Ainda que o New Deal talvez seja o caso mais ilustrativo desse argumento, dois exemplos recentes demonstram a centralidade das políticas macroeconômicas nas sociedades contemporâneas: o "fechamento" (shutdown) do governo estadunidense por algumas semanas no mês de outubro de 2013 e as políticas de austeridade exigidas dos países europeus que compõem a União Europeia.

No caso estadunidense, o presidente Barack Obama vivenciou entre os dias $1^{\circ} \mathrm{e}$ 17 de outubro de 2013 uma situação na qual mais de oitocentos mil servidores foram forçados a sair de licença temporária e mais de um milhão foram obrigados a se apresentar ao trabalho sem saber se iriam ser remunerados, após ter sido incapaz de celebrar um acordo no Congresso sobre a previsão de receitas para despesas públicas e, principalmente, sobre a elevação do limite legal de endividamento público do governo federal. Diversos serviços públicos foram fechados no período. ${ }^{1}$

Embora o fato imediato por trás do fechamento do governo estadunidense tenha sido a ausência de um acordo político no Congresso, uma das principais justificativas para a discórdia era de natureza macroeconômica: congressistas do partido republicano se opunham a financiar as despesas de um governo supostamente endividado acima de suas capacidades e que apoiara a criação de uma ampla política pública de saúde anos antes, a qual provocaria uma elevação nos gastos públicos. Em 2011, o congressista republicano Joe Walsh, opositor do governo de Barack Obama, chegou a afirmar que "o

\footnotetext{
${ }^{1}$ Essa foi a estimativa do jornal Washington Post. Ver: <http://www.washingtonpost.com/blogs/wonkblog/wp/2013/09/30/absolutely-everything-you-need-toknow-about-how-the-government-shutdown-will-work>. Posteriormente, o relatório oficial publicado pela Presidência dos Estados Unidos confirmou os números. O relatório está disponível em: <http://www.whitehouse.gov/sites/default/files/omb/reports/impacts-and-costs-of-october-2013-federalgovernment-shutdown-report.pdf> (último acesso em 30 de setembro de 2014).
} 
país talvez precisasse de uma terapia de choque" para entender os limites dos gastos públicos; o "fechamento" do governo era uma das medidas dessa proposta de terapia. ${ }^{2}$ Em outras palavras, discordâncias sobre a política fiscal resultaram no "fechamento" do governo estadunidense.

O caso europeu talvez seja ainda mais exemplar da centralidade das políticas macroeconômicas. As políticas de austeridade exigidas dos diversos países da União Europeia, em particular dos países do sul como Grécia, Itália, Espanha e Portugal, têm sido objeto de protestos públicos e de críticas por vários movimentos sociais. As medidas de austeridade variam de país para país e representam a ideia de que países com elevados índices de endividamento público devem adotar ações impopulares, como corte de gastos públicos, redução e extinção de benefícios previdenciários, além de corte nos investimentos público, para reduzir o endividamento. Somente na Grécia, entre 2010 e 2011, centenas de milhares de pessoas tomaram as ruas para protestar contra as políticas de austeridade. ${ }^{3}$

Apesar da centralidade das políticas macroeconômicas, que afetam, por exemplo, as taxas de crescimento, de desemprego e de inflação, não é incomum que as controvérsias existentes sobre elas se restrinjam a pequenos grupos e círculos de pessoas. As políticas macroeconômicas são geralmente objeto de interesse de economistas. Discussões sobre políticas monetária, fiscal e cambial são concentradas nas Faculdades de Economia, em centros de pesquisa especializados e nos jornais e periódicos econômicos, que fazem uso de jargões usualmente áridos e pouco compreensíveis.

Entretanto, como os próprios exemplos mencionados sugerem, há um amplo campo de pesquisa a ser explorado que não se restringe a análises econômicas das políticas macroeconômicas. A relação entre demandas sociais e políticas macroeconômicas, o modo como essas políticas são apresentadas e discutidas no debate público democrático e a influência das instituições políticas e de regras jurídicas na delimitação de opções para elas são somente alguns exemplos desse campo mais amplo que ainda pode se desenvolver.

Nesse sentido, esta dissertação apresenta os resultados de uma pesquisa que tenta compreender os papéis que o direito pode ter para políticas macroeconômicas. Ao

\footnotetext{
2 A entrevista está disponível em: <http://foxnewsinsider.com/2011/02/28/rep-walsh-on-spending-thiscountry-may-need-shock-therapy> (último acesso em 30 de setembro de 2014).

${ }^{3}$ As manifestações foram lideradas pelo Movimento dos Indignados (Indignant Citizens Movement). Para mais, ver: <http://indignants11.blogspot.com.br/> (último acesso em 30 de setembro de 2014).
} 
invés de analisar todas as políticas macroeconômicas, escolheu-se pesquisar apenas a relação entre uma delas, a política fiscal, e o direito. Em suma, esta pesquisa se propõe a analisar somente as possíveis relações entre direito e a política fiscal nas últimas décadas no Brasil.

A política fiscal, entendida como a gestão das receitas e despesas do estado e a quantidade de endividamento público, é uma das principais políticas macroeconômicas de qualquer estado contemporâneo. Para se ter uma ideia da dimensão de sua importância no Brasil, a política fiscal diz respeito à gestão pelo governo federal de um orçamento que em 2014 chegou a $\mathrm{R} \$ 2,5$ trilhões, o que corresponde a aproximadamente $50 \%$ do PIB brasileiro, além da gestão de uma dívida bruta do governo geral (o que inclui os governos estaduais e municipais) de mais de $\mathrm{R} \$ 3$ trilhões e de uma dívida líquida de $\mathrm{R} \$ 1,81$ trilhão. ${ }^{4}$ É fácil perceber que qualquer decisão relativa à política físcal tem o potencial de impactar os índices brasileiros de crescimento, desemprego, investimento, inflação e endividamento público.

Neste trabalho, a política fiscal corresponderá apenas à gestão pelo estado da quantidade do gasto e do endividamento para o setor público consolidado, o que envolve o conjunto das finanças públicas municipais, estaduais e federal. O componente da arrecadação da política fiscal, como impostos, taxas e outras receitas, não será objeto da pesquisa. Portanto, o regime jurídico da política fiscal a ser estudado está relacionado ao que a literatura jurídica costuma nomear de "direito financeiro", não incluindo o direito tributário. Como se perceberá, essa delimitação está relacionada ao próprio histórico de reforma do regime jurídico da política fiscal no país em anos recentes.

\section{Problemas de pesquisa}

A partir dessa delimitação do tema, três são os principais problemas desta pesquisa: o que é o regime jurídico da política fiscal no Brasil? Como esse regime foi reformado? Quais são os seus impactos para a política fiscal?

Como se nota, o primeiro problema de pesquisa corresponde à própria definição do seu objeto. A questão "o que é o regime jurídico da política fiscal?" reflete a condição atual da pesquisa acadêmica sobre o tema, em que não existe literatura consolidada a respeito da relação entre direito e uma das principais políticas

\footnotetext{
${ }^{4}$ Para os dados, ver a Lei Orçamentária Anual de 2014 (Lei 12.952, de 20 de janeiro de 2014) e a Nota para a Imprensa sobre política fiscal do Banco Central, publicada em 30 de setembro de 2014 (Banco Central, 2014).
} 
macroeconômicas do estado brasileiro. Caso essa consolidação existisse, o objeto talvez pudesse ser considerado como dado e outras discussões poderiam ser diretamente desenvolvidas.

A responsabilidade por tal lacuna não pode ser imputada exclusivamente aos juristas e tampouco aos economistas, mas, talvez, à precariedade do diálogo entre eles. Ainda assim, acredita-se que um estudo que congregue perspectivas econômicas e jurídicas seja essencial para compreender o desenvolvimento da gestão das políticas macroeconômicas em uma democracia. Daí a importância de ter como um dos problemas de pesquisa a própria definição do objeto a ser pesquisado.

Esta pesquisa se baseia em duas ideias gerais para defender que uma pesquisa de direito e macroeconomia tem o potencial de revelar detalhes da gestão macroeconômica em uma democracia. Essas ideias fornecem uma espécie de estrutura de base a hipóteses específicas sobre o regime jurídico da política fiscal no Brasil, que se apresentam como possíveis respostas aos problemas de pesquisa apresentados.

A primeira é a de que análises de textos legais e constitucionais, de decisões administrativas e judiciais, bem como da própria reflexão doutrinária sobre gasto e endividamento público, devem ser feitas a partir de uma perspectiva que permita o estudo conjunto do contexto histórico de criação de tais institutos e normas, além de seus impactos na economia, nas instituições políticas e jurídicas e no controle social da política fiscal. Nesse sentido, a primeira ideia que orienta esta pesquisa é a de que ela não pode se dedicar somente a uma sistematização lógica de institutos e normas jurídicas, como o que se costuma encontrar nos manuais e cursos de direito financeiro. A despeito da importância desta atividade, principalmente para criar condições para a reprodução de decisões e interpretações administrativas, judiciais e doutrinárias sobre o tema, ela não permite reconhecer e interpretar a dinâmica histórica do direito da política fiscal. Desse modo, este trabalho se propõe a inserir as reflexões jurídicas sobre política fiscal e, em particular, sobre despesas e endividamento público, nos diversos contextos políticos, econômicos e sociais que dão sentido(s) à sua criação e à sua disputa.

A segunda ideia que guia este trabalho é a de que, ao escolher como principal problema de estudo o regime jurídico da política fiscal, sua reforma e seus impactos, no contexto democrático brasileiro, esta pesquisa possui ao menos uma diferença epistemológica relevante em relação às reflexões econômicas e jurídicas mais comuns sobre o tema: ela não precisa se comprometer com nenhum discurso específico sobre política econômica. Em geral, trabalhos jurídicos costumam se filiar - intencionalmente 
ou não e de forma explícita ou não - a certas correntes econômicas de pensamento. Os estudos econômicos, por sua vez, constituem as próprias correntes econômicas existentes. Esta pesquisa, contudo, parte do pressuposto de que o estudo do regime jurídico de qualquer política macroeconômica não precisa ser realizado de uma perspectiva neokeynesiana, novokeynesiana, monetarista, neoclássica ou qualquer outra posição. Ela pode se limitar a descrever como diferentes normas jurídicas e instituições privilegiam certas correntes econômicas em detrimento de outras ao longo do tempo, especialmente explorando o modo como atores sociais mobilizam o direito e diferentes instituições em um contexto democrático para gerir uma política macroeconômica. Isto não significa defender que este trabalho adote uma postura indiferente ao debate econômico em uma democracia. Este tópico será mais explorado a seguir, no capítulo 1.

Em síntese, as duas ideias que motivam este trabalho sugerem que uma pesquisa de direito e macroeconomia consegue colocar no centro das preocupações teóricas questões sobre como o Estado tem gerido políticas macroeconômicas por meio de regras e princípios jurídicos em um contexto democrático, o que envolve discussões sobre relações federativas, separação de poderes, discricionariedade da gestão da política fiscal e mecanismos de controle social dessas políticas. Uma descrição do regime jurídico da política fiscal em um contexto democrático talvez permita compreender aspectos fundamentais da gestão macroeconômica em uma sociedade, que poderiam ficar obscurecidos em debates "puramente" econômicos, principalmente a respeito das opções políticas e jurídicas que têm sido adotadas. Alguns exemplos desses aspectos são as escolhas sobre se política fiscal é definida em âmbito da União ou no âmbito regional, se as principais competências relativas ao tema são atribuídas ao Legislativo ou ao Executivo, sobre quais metas para a política fiscal são ou devem ser priorizadas e sobre mecanismos de transparência da política fiscal. Uma descrição apurada desses elementos "não econômicos" da política fiscal, que normalmente são definidos por regras e princípios jurídicos, talvez possa até mesmo permitir a identificação de suas tendências de desenvolvimento institucional, político e econômico.

É evidente que a mera explicação dessas ideias mais gerais já recoloca os problemas de pesquisa com ainda mais força. Qual a efetiva relevância que o direito tem para uma política macroeconômica? Atores sociais mobilizam o direito para o alcance de determinados fins macroeconômicos? Quais os impactos do direito na gestão de uma política macroeconômica? Não é possível responder a essas perguntas de modo satisfatório sem que antes se caminhe por todo o percurso da pesquisa. Ainda assim, os 
próximos parágrafos apresentam um sumário da organização que a pesquisa adotou e suas hipóteses específicas.

\section{Estruturação do trabalho e observações metodológicas}

A delimitação mais específica de um campo de pesquisa sobre as relações entre política fiscal, direito e democracia será feita no capítulo 1. Para delimitar esse campo de pesquisa, foi realizada uma revisão da bibliografia econômica sobre política fiscal a partir do texto de Bénassi-Quére et al. (2010). É importante salientar, desde já, que o capítulo 1 não tem a intenção de apresentar uma história das ideias econômicas sobre política fiscal, mas somente de expor um panorama sobre as principais posições teóricas a respeito da política fiscal na literatura econômica contemporânea, que permitirão guiar os capítulos posteriores.

$\mathrm{Na}$ sequência do capítulo 1, apresenta-se uma revisão da literatura sobre instituições e política fiscal, que reúne tanto textos de economistas como de cientistas políticos. Desenvolve-se o argumento de que questões jurídicas, políticas e econômicas devem ser analisadas conjuntamente para a compreensão mais ampla do desenvolvimento da política fiscal em uma democracia. Ao final do capítulo 1, define-se com mais clareza a possível contribuição que uma pesquisa de direito e macroeconomia preocupada com questões de legitimidade democrática podem trazer para esse campo de reflexões.

Os demais capítulos da dissertação analisam o regime jurídico da política fiscal no Brasil. Esta pesquisa entende que a análise de qualquer regime jurídico deve se desenvolver em três diferentes níveis: (i) o da delimitação das regras e dos princípios jurídicos $^{5}$ que constituem o referido regime; (ii) o da discussão sobre o contexto de criação ou reforma desse regime; (iii) o da implementação desses princípios e regras. Esses três níveis correspondem aos capítulos 2, 3 e 4 desta dissertação, respectivamente.

O primeiro nível apresenta o regime jurídico da política fiscal que foi reformado no país nas últimas décadas, o que será feito no capítulo 2. As regras e princípios determinam formalmente os objetivos da política fiscal e sua organização define o

\footnotetext{
${ }^{5}$ Adota-se aqui a terminologia de regras e princípios jurídicos na concepção de Robert Alexy, tal como ela foi explicada por Virgílio Afonso da Silva. Ou seja, regras e princípios são normas jurídicas que servem de balizas objetivas para a atividade de interpretação jurídica e que podem ser distinguidas logicamente - não em termos de intensidade. Em síntese, regras devem ser aplicadas integralmente: se uma regra é válida, ou realizamos exatamente o que ela prescreve ou não a aplicamos. Os princípios, por sua vez, são mandamentos de otimização: sua realização pode ser obstada por outros princípios, o que permite o sopesamento de princípios colidentes. Ver: Silva (2003, pp. 607-612).
} 
cenário geral para as discussões seguintes a respeito de como o regime jurídico da política fiscal foi reformado e quais são os seus impactos. Esse capítulo está organizado em duas seções principais, com uma terceira seção que conclui o capítulo, resumindo seus principais argumentos. A primeira seção apresenta as reformas promovidas durante a década de 1980 nas regras e princípios jurídicos da política fiscal. A segunda organiza a reforma do regime jurídico promovida ao longo da década de 1990 em quatro âmbitos, que serão apresentados abaixo.

A hipótese do capítulo 2 é a de que o atual regime jurídico da política fiscal no país se consolidou em 2000, com a aprovação da Lei de Responsabilidade Fiscal. A Lei de Responsabilidade Fiscal define em grande medida as principais características da moldura jurídica da política fiscal no país. Argumenta-se ainda que, enquanto a reforma da década de 1980 não estava explicitamente conectada a uma agenda de ajuste fiscal, a reforma do regime jurídico da política fiscal da década de 1990 tinha uma clara intenção de promover o ajuste das contas públicas do setor público consolidado.

A hipótese de que a reforma do regime jurídico da política fiscal se consolidou com a aprovação da Lei de Responsabilidade Fiscal implica afirmar que o que normalmente se entende por direito - constituição, leis, resoluções, portarias, jurisprudência, acordos internacionais, interpretações administrativas, doutrina - foi considerado por agentes públicos como central para a gestão da política fiscal no país. É esse conjunto de instituiçõos jurídicas que se denomina aqui de regime jurídico da política fiscal, que denota as regras e os princípios jurídicos voltados para a gestão da política fiscal pelas autoridades públicas.

A organização do regime jurídico da gestão da política fiscal em regras e princípios se deu a partir da leitura de pesquisas anteriores sobre o tema e do estudo de decisões judiciais e administrativas, além de leis, emendas constitucionais e resoluções que foram elaboradas no período. A preocupação central desta pesquisa nesse nível é compreender e organizar as regras e princípios jurídicos para a política fiscal oriundos da reforma da década de 1990. Propõe-se que essas regras e princípios alteraram quatro dimensões: (i) centralizaram prerrogativas fiscais na União; (ii) centralizaram prerrogativas fiscais no Executivo, em relação ao Legislativo; (iii) estabeleceram limites legais para despesas e endividamento público, além de metas para a política fiscal; e (iv) criaram novos mecanismos de transparência e prestação de contas.

Para a análise da reforma da década de 1980, foi realizada pesquisa documental nos autos do processo da ação popular de nº 84.20753-0 (número original 230-AD184), 
ajuizada por Élquisson Soares em 1984, à época Deputado Federal, em face do Ministro da Fazenda e Presidente do Conselho Monetário Nacional e do Banco Central do Brasil e seu Presidente, perante a $5^{\text {a }}$ Vara da Justiça Federal de Brasília. A ação reúne diversos documentos relevantes do período, além de ter sido peça-chave na dinâmica da reforma na década de 1980.

A pesquisa ainda fez uso dos anais da constituinte, em especial das reuniões da Comissão do Sistema Tributário, Orçamento e Finanças e da Subcomissão de Orçamento e Fiscalização Financeira, para identificar como o tema do ajuste fiscal foi discutido nas referidas reuniões. ${ }^{6}$

Além desses documentos e da revisão da literatura, para a organização das regras e princípios jurídicos da política fiscal, foram analisadas os diplomas normativos mencionados pelas pesquisas estudadas, o que envolveu um grande número de decretos presidenciais, medidas provisórias, leis ordinárias, leis complementares, resoluções e emendas constitucionais. A literatura mobilizada, os documentos, as decisões judiciais e os diplomas normativos utilizados estão mencionados no capítulo 2.

Também foram incorporadas à pesquisa as decisões do Supremo Tribunal Federal que discutiram a constitucionalidade das regras e dos princípios aprovados durante a reforma, em especial a partir das decisões sobre a constitucionalidade da Lei de Responsabilidade Fiscal, e da única decisão do Supremo Tribunal Federal sobre desvinculação das receitas da União de que se tem conhecimento.

A organização de regras e princípios é geralmente o primeiro passo das pesquisas jurídicas, mas sua mera descrição é insuficiente para a análise de qualquer regime jurídico. As regras podem ser simplesmente ignoradas ou seletivamente implementadas por tribunais inferiores e burocratas, ainda que elas sejam declaradas constitucionais, e o esforço de organizá-las formal e logicamente tende a obscurecer as disputas políticas, culturais e econômicas que antecederam a sua criação.

Desse modo, a segunda etapa da análise da política fiscal proposta neste trabalho é a discussão sobre o contexto de aprovação dessas regras, o que será feito no capítulo 3. Nesse nível de análise, o trabalho busca contribuir com a literatura existente sobre o tema ao explicitar influências internacionais na aprovação do regime jurídico da política fiscal. Ao final do capítulo 3, propõe-se uma nova interpretação sobre o contexto que

\footnotetext{
${ }^{6}$ Para esta pesquisa, foram utilizados os anais da constituinte disponibilizados em meio eletrônico pela Câmara dos Deputados: <http://www2.camara.leg.br/atividadelegislativa/legislacao/Constituicoes_Brasileiras/constituicao-cidada/publicacoes/anais-da-assembleianacional-constituinte> (último acesso em 14 de outubro de 2014).
} 
determinou a aprovação da Lei de Responsabilidade Fiscal no Brasil, que combina fatores domésticos com influências internacionais. Ao final desse capítulo, espera-se que fique claro como o estudo do regime jurídico da política fiscal exige uma pesquisa atenta tanto às demandas domésticas como às internacionais sobre a política fiscal.

A análise do contexto da reforma do regime jurídico da política fiscal foi feita a partir do estudo dos documentos dos acordos entre Brasil e FMI no período entre 19982006, disponibilizados no sítio eletrônico da instituição multilateral, das discussões legislativas que precederam a aprovação das leis apresentadas no capítulo 2, de documentos publicados pelo Poder Executivo federal na promoção de programas de ajuste fiscal ao longo da década de 1990 e do estudo de entrevistas de agentes públicos e de notícias de jornais. ${ }^{7}$

Por fim, o capítulo 4 formula uma resposta à pergunta sobre os impactos do direito na gestão da política fiscal. Entende-se que a reforma impactou significativamente quatro âmbitos da política fiscal: (i) novos mecanismos de transparência e prestação de contas da política fiscal transformaram os instrumentos de controle social da política fiscal e tendem a estruturar o debate público sobre o tema; (ii) a gestão da política fiscal passou a se basear em metas e regras, embora o Executivo federal ainda detenha discricionariedade jurídica e de fato para modificá-la; (iii) o poder fiscal se concentrou no Poder Executivo, em detrimento do Poder Legislativo; (iv) o poder fiscal reduziu a margem de manobra para os governos estaduais perseguirem suas próprias políticas fiscais.

Esse último nível de análise discute a implementação do regime jurídico, buscando identificar como as regras e os princípios jurídicos foram aplicados e interpretados. O estudo de seus efeitos para a política fiscal se deu por meio da revisão de literatura sobre o tema, de interpretação dos dados econômicos do setor público consolidado nas décadas de 1990 e 2000, e dos relatórios publicados pelo governo federal após a publicação da Lei de Responsabilidade Fiscal. Na discussão específica sobre mecanismos de transparência e prestação de contas, foram analisados relatórios de instituições multilaterais e do Tribunal de Contas da União, além de outras pesquisas sobre o tema e de projetos de lei que tentam modificá-los.

\footnotetext{
${ }^{7}$ A pesquisa fez uso dos sítios eletrônicos dos jornais $O$ Estado de São Paulo, Folha de São Paulo e $O$ Globo, pesquisando o seu acervo, no período entre 1998 e 2006, por meio das palavras chaves "Lei de Responsabilidade Fiscal", "Fundo Monetário Internacional" e FMI. Foram selecionadas as entrevistas públicas de atores que representavam o Executivo Federal. As entrevistas serão apresentadas no capítulo 3 , em especial na seção 3.4.
} 
Acredita-se que esse método de análise possa gerar uma melhor compreensão do regime jurídico da política fiscal, o que passará a ser feito nos próximos capítulos. 


\section{Capítulo 1 - Direito e macroeconomia: um estudo da política fiscal em uma democracia}

Este primeiro capítulo tem o objetivo de delimitar a perspectiva que se denomina de direito e macroeconomia para o estudo do regime jurídico da política fiscal no país. O capítulo tem a intenção de indicar um campo de reflexões e pesquisas dentro do qual um estudo sobre o regime jurídico da política fiscal possa se inserir. Esta pesquisa defende que o estudo de políticas macroeconômicas não precisa ser feito somente de uma perspectiva econômica. Análises que levam em consideração elementos políticos e jurídicos também contribuem para compreender tanto o funcionamento quanto a legitimidade democrática de políticas macroeconômicas em qualquer sociedade.

De um lado, argumenta-se que uma pesquisa de direito e macroeconomia deve compreender as funções do direito para a política macroeconômica; no caso desta pesquisa, das funções do regime jurídico para a política fiscal. Essas funções dizem respeito à forma como o direito facilita ou dificulta objetivos para a política fiscal. Uma análise do regime jurídico da política fiscal pode chegar à conclusão, por exemplo, de que o atual regime jurídico dificulta o aumento do gasto e do endividamento público, o que pode ser disfuncional caso o objetivo das autoridades responsáveis pelas decisões fiscais seja aumentar o déficit público. Outra conclusão possível seria constatar que o regime jurídico talvez não dificulte o endividamento público, o que pode ser contrário ao interesse de determinados agentes que entendem que a relação entre dívida pública e o produto interno bruto deveria ser constante. Esses são exemplos de análises de direito e macroeconomia que poderiam ser classificadas como funcionais, uma vez que elas se referem ao impacto do regime jurídico para a política fiscal, dados certos objetivos.

Para além das questões sobre as funções do direito para as políticas macroeconômicas, esta pesquisa entende que o regime jurídico da política fiscal não pode ser compreendido se não se leva em consideração que o direito também estrutura reivindicações sociais sobre a legitimidade democrática dos objetivos da política fiscal. Essa dimensão democrática da análise é central para esta pesquisa sobre os papéis do direito para a política fiscal. A análise do regime jurídico da política fiscal dessa perspectiva pode demonstrar de que maneira diferentes atores sociais defendem certas concepções de política fiscal como democraticamente legítimas por meio do direito. Deve-se deixar claro que não se trata de definir uma concepção específica de democracia antes mesmo de se iniciar a análise do regime jurídico da política fiscal. 
Trata-se, na realidade, de incluir no campo de reflexão de direito e macroeconomia a questão sobre como diferentes atores, ao gerirem a política fiscal, mobilizam o regime jurídico na defesa da legitimidade democrática de suas ações e de seus objetivos.

Com o intuito de esclarecer como esta pesquisa de direito e macroeconomia tenta desenvolver um estudo preocupado ao mesmo tempo com questões funcionais e de legitimidade democrática do regime jurídico da política fiscal, o capítulo está dividido da seguinte maneira: em primeiro lugar, será apresentado um resumo da literatura econômica contemporânea sobre política fiscal (item 1.1.). O objetivo desta primeira subseção não é o de realizar um estudo exaustivo sobre a história das ideias econômicas a respeito da política fiscal, mas tão somente uma exposição sobre diferentes posições teóricas existentes atualmente. A partir do diagnóstico de um amplo desacordo entre economistas a respeito das formas, da relevância e dos objetivos da política fiscal, a sequência do capítulo apresentará a literatura que estuda o modo como diferentes contextos sociais, instituições políticas e regras e princípios jurídicos impactam a política fiscal (item 1.2.). Esta literatura, entretanto, não coloca como centro das preocupações teóricas a questão da relação entre política fiscal e legitimação democrática. Suas principais preocupações tendem a ser com esses aspectos que se chamaram de funcionais. Nesse contexto, o último item deste capítulo apresentará a contribuição que pesquisas guiadas por certa perspectiva de direito e macroeconomia podem trazer na análise de limites e possibilidades da gestão macroeconômica da sociedade em uma democracia (item 1.3.), o que permitirá que a descrição sobre o caso brasileiro prossiga no capítulo 2.

\subsection{Dissenso na literatura econômica sobre política fiscal}

Para economistas, a expressão "política fiscal” designa as práticas de gestão das receitas e das despesas pelo Estado, incluindo a definição do montante de déficits/superávits e da quantidade da dívida pública. A política fiscal é reconhecida como uma das mais importantes políticas macroeconômicas que o Estado emprega para gerir a economia.

O possível consenso sobre a definição do que seja a política fiscal contrasta com a discordância existente entre os economistas a respeito de seus efeitos e sua gestão. $\mathrm{O}$ capítulo três do livro de Bénassi-Quére et al. (2010), Economic Policy, demonstra que as formulações de Keynes sobre o papel da política fiscal na manutenção de um 
determinado nível de demanda agregada suficiente para manter o pleno emprego foram inicialmente criticadas por autores neoclássicos e, posteriormente, pela literatura sobre sustentabilidade da dívida pública. ${ }^{8}$ Os autores demonstram que há amplo desentendimento a respeito da política fiscal, embora concluam que certos avanços de estudos recentes possam fornecer importantes ideias para sua gestão. ${ }^{9}$

Para os autores, as propostas keynesianas sobre elevação da demanda agregada por meio da política fiscal para garantia do pleno emprego e do crescimento econômico foram inicialmente criticadas de três diferentes perspectivas econômicas que podem ser resumidas da seguinte forma: ( $i$ ) a política fiscal é ineficaz porque ela provoca um efeito de deslocamento (crowding out) completo; (ii) as propostas keynesianas se equivocam na análise sobre a rigidez da oferta; (iii) a política fiscal nos termos keynesianos ignora o fenômeno da equivalência ricardiana (BÉNASSI-QUÉRE et al., 2010, pp. 180-196).

De acordo com o primeiro argumento, a política fiscal seria ineficaz porque a expansão fiscal seria acompanhada de uma deterioração das finanças públicas, o que provocaria um aumento das taxas de juros e uma subsequente depressão da demanda privada. Logo, o efeito de deslocamento seria completo após esse ciclo, virtualmente anulando qualquer possível ganho com a expansão fiscal inicial pela depressão final da demanda privada. Pior, o cenário posterior seria mais prejudicial que o cenário inicial, pois acompanharia a deterioração das finanças públicas, o aumento das taxas de juros e a depressão do consumo privado.

No segundo argumento, a hipótese dos críticos é a de que os preços se adaptam rapidamente à expansão da demanda, ao contrário do que supostamente seria esperado pela teoria keynesiana. Ou seja, um aumento da demanda agregada por meio da política fiscal gera um rápido aumento dos preços, o que só implicaria aumento da produção - o único elemento que realmente garantiria o pleno emprego e o crescimento - se os preços subissem significativamente. De qualquer modo, o impacto inflacionário das expansões fiscais seria elevadíssimo, o que provavelmente não compensaria sua utilização.

\footnotetext{
${ }^{8}$ Para uma história sobre a evolução das ideias econômicas a respeito da política fiscal, ver Lopreato (2013, pp. 1 - 75). Não há qualquer pretensão de reproduzir essa exposição aqui.

${ }^{9}$ Nas palavras dos autores: "Décadas de trabalho sobre política fiscal não produziram uma doutrina de uso universal, atemporal, nem conduziram a um conjunto de recomendações "one-size-fits-all". Ao contrário, elas forneceram para nós uma caixa de ferramentas analítica e uma riqueza de dados empíricos que são particularmente relevantes para informar a política, não somente em tempos normais, mas também em tempos históricos, como o da crise econômica de 2008-2009." (2010, pp. 219-220, tradução nossa). No original: "Decades of work on fiscal policy have not produced a universal, atemporal doctrine of use, nor do they lead to a "one-size-fits-all" set of recommendations. Instead, they have provided us with an analytical toolbox and a wealth of empirical studies that are particularly relevant to inform policymaking not only in normal time, but also in historical times such as the 2008-09 economic crisis."
} 
Por fim, o terceiro argumento sugere que o aumento da demanda pública implica redução proporcional imediata do consumo privado. Desta perspectiva, o consumidor racional anteciparia que o aumento corrente dos gastos públicos significa uma elevação correspondente dos impostos no futuro, para compensar o aumento do déficit ou diminuição do superávit corrente. Nesse caso, o consumidor racional interpretaria uma expansão fiscal como um sinal de que se deve parar de consumir e começar a poupar no tempo presente. Como no primeiro argumento, neste terceiro argumento também ocorre o efeito deslocamento (crowding out). Porém, a razão é outra: não é a taxa de juros que é alterada, provocando uma posterior redução da demanda privada; o que muda são as expectativas dos consumidores, que imediata e automaticamente parariam de consumir e compensariam a expansão fiscal na composição da demanda agregada. ${ }^{10}$

Em paralelo a essas três críticas, que, por sua vez, também foram controvertidas por economistas mais próximos do pensamento keynesiano, outra linha de crítica foi apresentada por meio das ideias de solvência e sustentabilidade da dívida pública. A estrutura desta crítica é distinta das três já apresentadas, pois ela duvida da própria capacidade do estado promover uma política fiscal no longo prazo e apresenta objetivos concorrentes que deveriam nortear essa política, para além dos objetivos de crescimento e garantia do pleno emprego, tipicamente keynesianos (BÉNASSI-QUÉRE et al., 2010, pp. 196-202).

A crítica ao pensamento keynesiano a partir das ideias de solvência e sustentabilidade da dívida pública se torna ainda mais relevante em um cenário internacional marcado pela mobilidade do capital dos investidores e no qual os títulos da dívida pública dos diferentes países constituem um dos investimentos mais atrativos. A impossibilidade de qualquer estado financiar suas despesas exclusivamente por meio das receitas oriundas de tributos e de eventuais atividades econômicas correntes cria as condições nas quais os estados devem emitir títulos da dívida pública com frequência. Agentes de mercado tendem a financiar a dívida pública somente caso certas condições a respeito do prêmio de risco dos títulos e da trajetória esperada da dívida pública sejam satisfeitas (SCHAFER e STREECK, 2013) ${ }^{11}$. Nesse cenário, certos atores sociais passam a ter fortes incentivos para criar outros critérios para analisar a gestão das

\footnotetext{
${ }^{10}$ Para as três críticas, ver: BÉNASSI-QUÉRE et al., 2010, pp. 180-196

11 Schafer e Streeck explicam que, após a Segunda Guerra Mundial, houve uma tendência geral de crescimento da dívida pública na maior parte dos países ocidentais. Os autores argumentam que o aumento dos gastos públicos foi acompanhado do aumento da arrecadação de impostos até o final dos anos 1960, mas depois dessa década o aumento da taxação não acompanhou o aumento do endividamento público, que se acelerou. Ver o capítulo 1 do livro organizado por Schafer e Streeck (2013).
} 
receitas e despesas dos estados, além da manutenção do pleno emprego dos recursos econômicos disponíveis (LOPREATO, 2006). ${ }^{12}$ Para investidores supostamente racionais, interessados unicamente em receber o retorno econômico dos seus investimentos, a trajetória da dívida no médio prazo e o prêmio do risco assumido pelo investidor se tornam elementos centrais na definição dos investimentos a serem realizados. As ideias de solvência e sustentabilidade subsidiaram a criação desses critérios.

É possível analisar os conceitos de solvência e de sustentabilidade separadamente, embora eles costumem ser apresentados conjuntamente pela literatura econômica.

O conceito de solvência corresponde à situação em que os recursos disponíveis a um determinado agente permitem que suas obrigações sejam cumpridas. No caso dos estados modernos, em uma primeira análise, seria possível defender que o conceito é inaplicável. Afinal, o estado sempre poderia monetizar a dívida pública ou elevar os impostos para pagamento das dívidas ou financiamento do Estado. Porém, a monetização da dívida tende a provocar outras consequências na economia que nem sempre são politicamente aceitáveis, em especial a inflação. Além disso, qualquer governo, mesmo com amplo apoio nas urnas, enfrenta severas dificuldades de ordem política para elevar impostos com frequência, seja para pagamento dos detentores da dívida pública, seja para financiamento direto.

O conceito de sustentabilidade das finanças públicas, por sua vez, exprime a ideia de que a gestão da política fiscal pode provocar problemas de solvência no médio e no longo prazo. Ou seja, ainda que um país não enfrente problemas imediatos de solvência, a atual gestão das receitas e despesas do estado pode gerar impactos futuros que devem ser considerados na avaliação corrente das finanças públicas.

Em resumo, tanto a solvência do estado como a sustentabilidade da dívida pública se tornam conceitos que fundamentam a criação de critérios para subsidiar decisões sobre investimentos da perspectiva dos agentes privados e públicos que negociam títulos da dívida pública. Do lado dos agentes públicos que emitem os títulos

12 Para Lopreato (2006, p. 6), os principais marcos teóricos da emergência da literatura sobre sustentabilidade da dívida pública são três: (i) a crítica ao pressuposto keynesiano de que os agentes de mercado não alteram seus comportamentos após o anúncio das políticas econômicas; (ii) as abordagens sobre inconsistência intertemporal das políticas econômicas e o seu impacto nas decisões dos agentes; (iii) o surgimento da preocupação sobre a credibilidade das políticas econômicas, que também recoloca a questão sobre regras e discrição, a qual voltará a ser explorada mais a frente neste trabalho (ver capítulos $2,3$ e 4$)$. 
da dívida pública, esse cenário provoca uma mudança na avaliação dos critérios a respeito da política fiscal (LOPREATO, 2006). Afinal, se há o risco de o Estado não ser mais financiado, ou do custo desse financiamento ser constantemente elevado, há motivos para incorporar esses critérios na análise da política fiscal. Este é o contexto mais geral a partir do qual é possível afirmar que as preocupações sobre a política fiscal transitam entre a discussão sobre seus efeitos na manipulação da demanda agregada e a discussão sobre seus impactos na solvência do estado e na sustentabilidade da dívida pública.

Todas as possíveis controvérsias a respeito da política fiscal continuam sem solução no atual estágio de evolução do pensamento econômico, embora talvez seja possível identificar e diferenciar abordagens mais convencionais (mainstream) das menos aceitas (heterodoxas). A título de exemplo, é interessante reproduzir as recentes críticas do ganhador do prêmio Nobel de economia, Paul Krugman, a seus colegas Alesina e Ardagna. Krugman classifica o trabalho dos pares como um "completo ataque à proposição keynesiana de que o corte de gastos em uma economia produz futuras fraquezas" (2013, p. 7, tradução nossa). ${ }^{13}$ Ele conclui: "artigos e economistas que disseram à elite o que ela queria ouvir são celebrados, a despeito da abundância de provas de que eles estavam errados; críticos foram ignorados, não importa quão frequentemente eles estivessem certos" (2013, p. 7, tradução nossa). ${ }^{14}$ No mesmo artigo, Krugman dá tratamento semelhante a um famoso artigo escrito pelos colegas Reinhart e Rogoff.

Alesina e Ardagna haviam escrito um artigo conjuntamente no qual apresentaram estudos de casos de estímulos e ajustes fiscais em países da OCDE no período entre 1970 e 2007. No artigo, os autores argumentaram que cortes de impostos (no caso de estímulos fiscais) e cortes de gastos públicos (em casos de ajustes físcais) são mais indutivos ao crescimento do que o incremento dos gastos ou a elevação de impostos, respectivamente (ALESINA e ARDAGNA, 2010). Reinhart e Rogoff, por sua vez, apresentaram um amplo estudo comparado para concluir que países que alcançam uma dívida pública que exceda $90 \%$ do PIB tendem a cair de um penhasco em termos de crescimento econômico, uma vez que as condições fiscais ficariam tão deterioradas que seria impossível fomentá-lo via política fiscal (REINHART e ROGOFF, 2010).

\footnotetext{
${ }^{13}$ No original: "full front assault on the Keynesian proposition that cutting spending in a weak economy produces further weakness".

${ }^{14}$ No original: "Papers and economists who told the elite what it wanted to hear were celebrated, despite plenty of evidence that they were wrong; critics were ignored, no matter how often they got it right".
} 
Para os fins deste trabalho, essa controvérsia teórica é somente uma expressão do quanto a teoria econômica não apresenta ideias unívocas a respeito da política fiscal. ${ }^{15}$ É importante ressaltar que a controvérsia teórica também acaba se refletindo em controvérsias práticas. ${ }^{16}$ É comum verificar o uso de diferentes teorias para discutir a quantidade de recursos que deveriam ser utilizados para fomentar uma economia em crise; ou sobre se o estímulo deve ocorrer via gastos públicos ou via corte de impostos; ou, ainda, sobre quando a política fiscal de um país deve ser expansiva ou austera.

Nesse contexto de amplo desacordo entre os economistas, outra literatura passou a discutir os impactos de diferentes contextos institucionais, políticos e jurídicos para a política fiscal. Essa literatura permite colocar em segundo plano a discussão sobre as diferentes concepções econômicas a respeito da política fiscal - se a política fiscal deve ser usada como política anticíclica ou como ferramenta de sustentabilidade da dívida pública; se deve ser conduzida por meio de corte de impostos ou aumento de despesas.

Em um polêmico livro, Buchanan e Wagner (1977) talvez possam ser considerados como precursores dessa abordagem. Conectados historicamente à teoria da escolha pública (public choice), eles argumentam que o principal problema da política fiscal não é econômico, mas político. Da perspectiva da teoria da escolha pública, os políticos são agentes auto-interessados. Desse modo, os objetivos econômicos por excelência não teriam espaço na gestão política das finanças públicas. As escolhas sobre política econômica, em especial sobre política fiscal, seriam falhas porque são políticas, não econômicas.

O título do livro da dupla, democracia em déficit: o legado político de Lorde Keynes, resume a principal tese dos autores. Buchanan e Wagner argumentam que, em uma democracia, os agentes públicos responsáveis por definir a política fiscal estão mais interessados em garantir a própria reeleição ou a reeleição de membros do partido do que as boas condições da economia no longo prazo. ${ }^{17}$

\footnotetext{
${ }^{15}$ O conceito chave da discussão atual talvez possa ser expresso por meio da palavra "austeridade". Sobre o tema, ver ainda: Schaffer e Streeck (2013), Schui (2014) e Blyth (2013).

${ }^{16}$ A busca por relações de causalidade entre reflexões teóricas e práticas foge ao escopo desta pesquisa, embora represente uma reflexão essencial para o campo.

${ }^{17}$ A seguinte passagem do livro de Buchanan e Wagner sintetiza essa hipótese: "Os políticos têm, na maior parte das vezes, horizontes de curto prazo. Para a maior parte deles, cada eleição representa um ponto crítico, e o principal problema que eles enfrentam é como passar por esse desafio. [...] Isso não quer dizer que os políticos jamais olhem para além das próximas eleições ao escolherem seus cursos de ação, mas somente que as considerações de curto prazo dominam as ações da maior parte deles. Tais características, é claro, são um atributo inerente e necessário de uma democracia. Mas quando esse atributo necessário é aliado a uma constituição fiscal que não restringe o gasto ordinário e a tendências de geração de déficits, o resultado prenunciado é um desastre. Nós não queremos sugerir que nós rejeitemos
} 
Como se pode presumir, Buchanan e Wagner eram extremamente críticos à utilização da política fiscal pelo estado. A crítica dos autores está baseada em dois diferentes raciocínios: $(i)$ os políticos são responsáveis pela política físcal, mas não se preocupam com a economia, e sim com a própria reeleição; (ii) esse comportamento é prejudicial pois, no médio prazo, gera uma tendência crônica a déficits, o que é difícil de ser combatido. Essa é outra abordagem de crítica às propostas keynesianas, embora compartilhe de semelhanças com as críticas desenvolvidas a partir das ideias de solvência e sustentabilidade da dívida pública. Seria possível diferenciá-las, entretanto, porque Buchanan e Wagner enfatizam a natureza eminentemente política da ação estatal na política fiscal, e não seus aspectos econômicos.

Contudo, a reflexão iniciada por Buchanan e Wagner na década de 1970 não precisa estar necessariamente relacionada a uma corrente econômica específica. Em outras palavras, a pergunta de pesquisa apresentada pelos autores poderia ser reformulada da seguinte maneira: quais são os impactos de determinadas regras e desenhos institucionais na política fiscal, à luz das diferentes teorias macroeconômicas que a discutem? Possíveis respostas a essa pergunta independem das diferentes reflexões sobre os efeitos que o aumento do endividamento ou da poupança teria sobre a economia como um todo e, portanto, não precisariam ser apresentadas como uma crítica a Keynes. $^{18}$

controles públicos e políticos de nossos negócios, mas somente que os políticos sejam colocados uma vez mais em uma efetiva moldura constitucional na qual a manipulação orçamentária por propósitos de assegurar a sobrevivência política no curso prazo seja mais restrita, dando assim o escopo integral para o trabalho das forças de longo prazo, que são tão necessárias para o funcionamento suave de nossa ordem econômica. Assim como um alcoólatra deve aderir aos Alcoólatras Anônimos, uma nação bêbada em déficits e farta com o governo também deve aderir a um orçamento balanceado e à estabilidade monetária". (BUCHANAN e WAGNER, [1977], (2000), p. 166, tradução nossa). "Politicians themselves have, for the most part, short time horizons. For most of them, each election presents a critical point, and the primary problem they face is getting past this hurdle. [...] This is not to say that politicians never look beyond the next election in choosing courses of action, but only that such short-term considerations dominate the actions of most of them. Such features are, of course, an inherent and necessary attribute of a democracy. But when this necessary attribute is mixed with a fiscal constitution that does not restrain the ordinary spending and deficit-creating proclivities, the result portends disaster. We do not suggest that we relinquish political and public control of our affairs, but only that politicians be placed once again in an effective constitutional framework in which budgetary manipulation for purposes of enhancing shortrun political survival is more tightly restrained, thereby giving fuller scope to the working of the longterm forces that are so necessary for the smooth functioning of our economic order. Just as an alcoholic might embrace Alcoholics Anonymous, so might a nation drunk on deficits and gorged with government embrace a balanced budget and monetary stability".

${ }^{18}$ Vale ressaltar que essa reapresentação da pergunta não foi feita por Buchanan e Wagner. Os autores tinham uma explícita agenda de redução do papel do estado na economia e sua reflexão objetivava demonstrar a falência do uso da política fiscal. Eles criticavam o uso da política físcal pelos políticos como instrumento de manipulação da demanda agregada e desconfiavam da capacidade do poder público de estimular a economia e de gerir a dívida pública no longo prazo. Sobre o assunto, além de BénassiQuéri et al. (2010), ver também Lopreato (2006). 
Em um contexto de ampla discordância teórica e prática a respeito da política fiscal, este trabalho não pretende se filiar a nenhuma corrente econômica sobre o tema. Como já mencionado, ele não se alia à corrente keynesiana nem a nenhum de seus críticos, em qualquer de suas versões. Na realidade, o que o trabalho busca fazer é retomar a pergunta que poderia ter sido iniciada na década de 1970, mas tentando evitar a escolha de uma perspectiva única sobre os embates econômicos existentes. Acreditase que a análise das regras e princípios jurídicos permita esclarecer qual das correntes econômicas se tornou hegemônica em determinado momento histórico e quais são os mecanismos jurídicos e políticos que têm sido utilizados para garantir essa hegemonia, independentemente de seu "acerto" econômico.

Para que fique claro, não se trata de dizer que este trabalho adota uma perspectiva indiferente em relação ao debate econômico posto. Pelo contrário, entendendo-se que em uma democracia as cidadãs e os cidadãos devem ter o poder de influenciar todas as políticas governamentais - inclusive as econômicas - este trabalho se propõe a analisar como regras e princípios jurídicos têm estruturado a escolha social entre diferentes opções de política fiscal. Dois são os pressupostos desta afirmação, que serão mais bem explorados na última seção deste capítulo: (i) o primeiro é o de que o debate teórico entre economistas deveria servir para alimentar o embate público mais amplo entre as diferentes opções, mas nunca para dar uma resposta única, definitiva e supostamente técnica à controvérsia; (ii) o segundo é o de que princípios e regras jurídicas têm sido utilizados para promover certas correntes econômicas e que, em tese, seria possível estudá-los da perspectiva de possíveis ganhos ou déficits democráticos. A conclusão deste capítulo discutirá as possíveis contribuições de uma pesquisa que pretende se inserir em um campo de direito e macroeconomia explorando um pouco mais esses pressupostos.

Contudo, antes de passar a essa discussão, é essencial desenvolver a literatura existente a respeito dos impactos de instituições, regras e princípios jurídicos na gestão da política fiscal. A partir de Buchanan e Wagner, é possível identificar um campo de pesquisa que analisa as relações entre instituições, política, direito e política fiscal. Essa literatura traz importantes ideias que podem facilitar a delimitação do campo de uma pesquisa sobre o atual regime jurídico da política fiscal no Brasil.

\subsection{Regras, instituições e política fiscal}


É possível dividir a literatura que debate os efeitos de instituições, regras e princípios jurídicos na política fiscal em dois grandes grupos: (i) o grupo que se preocupa com os impactos de instituições políticas fundamentais de qualquer sistema político moderno na política fiscal - que esta pesquisa chamará de literatura política; e (ii) o grupo que discute como instituições, regras e princípios orçamentários afetam a política fiscal - a literatura institucionalista. ${ }^{19}$ Em relação ao primeiro grupo, a literatura tenta identificar os impactos de variáveis como presidencialismo, parlamentarismo, fragmentação da base de apoio do governo e grau de polarização política sobre a política fiscal. A literatura institucionalista busca discutir se instituições específicas que alteram o procedimento orçamentário têm efeitos sobre a política fiscal.

\subsubsection{A literatura política}

Para simplificar a análise, a literatura política pode ser agrupada em torno de três diferentes linhas de pesquisa: as relações entre ciclos políticos e política fiscal; as relações entre a estrutura do governo e a política fiscal; as relações entre partidos e a política fiscal. É importante ter em mente que essas pesquisas podem contribuir na análise da gestão da política fiscal no Brasil.

A literatura política, que pode ser analisada como um desdobramento direto das reflexões iniciadas por Buchanan e Wagner $(1977)^{20}$, consente sobre a existência de um ciclo político na gestão da política fiscal, seja por meio da expansão dos gastos, seja por meio de uma menor arrecadação de tributos em anos eleitorais. A literatura argumenta que, em anos eleitorais, há geralmente um crescimento de déficits fiscais, com uma política mais expansiva por parte do governo. Quanto aos impactos da estrutura do sistema político e das diferenças ideológicas/partidárias na política fiscal, contudo, a literatura é mais inconclusiva. Há estudos que apontam para resultados diferentes a respeito dos efeitos do presidencialismo e parlamentarismo, de governos uni ou multipartidários e de partidos de esquerda ou direita na política fiscal.

\footnotetext{
${ }^{19}$ Para um sucinto resumo sobre a literatura, ver Correa (2007).

${ }^{20}$ Barro (1979) também é um dos precursores dessa reflexão, mas sua tese é contrária à tese de Buchanan e Wagner. Enquanto estes são pessimistas, pois observam uma tendência crônica de geração de déficits em democracias representativas, Barro é considerado um dos criadores da teoria chamada de "tax smoothing", que basicamente sugere que os impostos em geral são mantidos de forma constante de modo a equalizar eventuais perdas do sistema fiscal. Analisando os casos de Estados Unidos e Grã-Bretanha, Barro afirma que essas tendências parecem se afirmar, principalmente com a análise dos períodos de guerra (deficitário) e paz (superavitário).
} 
As pesquisas que se dedicam à compreender a relação entre ciclo político e política fiscal - também chamada de modelos oportunistas (FRANZESE, 2002) sugerem que os agentes públicos não têm qualquer preferência ideológica sobre a geração de déficits e são impulsionados exclusivamente por motivações eleitorais, o que talvez possa ser interpretado como o desenvolvimento mais direto dos textos de Buchanan e Wagner. A expressão "ciclo político" sugere que os déficits fiscais são maiores em anos eleitorais, como um resultado da busca do governo por maior popularidade em relação ao eleitorado. ${ }^{21}$ Em uma importante distinção, Brender e Drazen (2004) sugerem que a existência desses ciclos políticos é mais frequente em países que são "novas democracias" do que em países que são "democracias consolidadas". 22

A linha de pesquisas sobre a relação entre estrutura do governo e a política fiscal é menos conclusiva. Roubini e Sachs (1989a, 1989b), por exemplo, estudam duas diferentes amostras de países da OCDE, no período entre 1960-1985, para afirmar que governos de coalização, típicos de países com representação proporcional, parlamentaristas e multipartidários, tendem a ter mais dificuldades na hora de realizar ajustes fiscais que governos de representação majoritária, tipicamente presidencialistas. ${ }^{23}$ Os autores sugerem que a diferença de velocidade e do volume da redução de déficits fiscais dos países da OCDE pode ser explicada por dificuldades políticas na gestão de um governo de coalizão. A lógica por trás do argumento é relativamente simples: em um governo de coalizão, os parceiros da coalizão teriam poder de veto para políticas que alterarem o status quo. Além da questão da fragmentação do governo, os autores também apontam que o tempo esperado do governo no poder pode afetar o resultado fiscal.

De Haan e Sturm (1994), entretanto, não encontraram nenhuma significância estatística na relação entre as mesmas variáveis usadas por Roubini e Sachs e a política fiscal. Os autores realizaram uma investigação de países da União Europeia nos anos 1980 e concluíram que não há diferença entre governos de coalizão, governos minoritários e governos unipartidários majoritários no desenvolvimento de déficits

\footnotetext{
${ }^{21}$ Bayar e Smeets (2005), De Haan e Mink (2005) e Persson e Tabellini (2002) apresentam estudos que confirmam essa hipótese. Ver ainda: Schuknecht (2000), para países menos desenvolvidos.

${ }^{22}$ Os autores definem novas democracias como aquelas democracias que aparecem no índice da Polity IV da Universidade de Maryland pela primeira vez no período entre 1960-2001. As democracias são consideradas novas nos quatro primeiros turnos eleitorais no período. As democracias consolidadas são as democracias que já apareciam no índice em 1960 ou a partir do quinto turno eleitoral no período.

${ }^{23}$ Em sentido semelhante, ver Alesina e Perotti (1995) e Persson e Tabellini (2002).
} 
fiscais. Por outro lado, eles encontraram correlações entre maior dívida pública e duas outras variáveis: a maior frequência de mudanças governamentais e a inexistência de procedimentos orçamentários.

Em uma importante distinção sobre a questão da fragmentação, Perotti e Kontopoulos (2002) argumentaram que não somente o tamanho da coalizão governamental, mas também o tamanho do Executivo (size of the cabinet), mensurado pelo número de ministros com competência para realizar gastos, é importante para mensurar a fragmentação que impacta os resultados fiscais. Em outras palavras, para os autores, além da fragmentação da base de apoio do governo no Congresso, o tamanho do governo também é significativo nos resultados fiscais. Woo (2001), por outro lado, confirma a hipótese sobre o tamanho do Executivo, mas não encontra qualquer correlação significativa entre resultados fiscais e o tipo de regime ou o fato do governo ser de coalizão ou não.

Por fim, a linha de pesquisa que discute a relação entre partidos e política fiscal - também chamada de modelo partidário (FRANZESE, 2002) - investiga se as motivações ideológicas influenciam a geração de déficits. As pesquisas realizadas são igualmente inconclusivas. $^{24}$

A literatura, portanto, parece entrar em consenso somente quanto à hipótese sobre a influência do período eleitoral em resultados fiscais. Em geral, conclui-se que, em períodos eleitorais, a tendência é de aumento dos gastos públicos e/ou de corte de impostos, o que dificultaria a obtenção de superávits ou pressionaria os déficits. Mesmo isso, contudo, não é necessariamente verdade para qualquer democracia representativa: pelo menos um estudo aponta que esse efeito só ocorre em "democracias novas", e não em "democracias consolidadas" (BRENDER E DRAZEN, 2004).

As possíveis críticas a esta primeira literatura sobre as instituições políticas e seus resultados sobre a política fiscal não se resumem à impossibilidade de se alcançar (talvez momentaneamente) resultados empíricos conclusivos. Uma crítica mais relevante, frequentemente apresentada na literatura que se discutirá a seguir, é a de que explicações sobre o resultado da política fiscal baseadas nessas "macroinstituições" são incapazes de dar conta das variações encontradas em países que as possuem de modo semelhante e mesmo assim apresentam resultados fiscais bastante distintos

\footnotetext{
${ }^{24}$ Ver, entre outros, Alesina e Roubini (1997), De Haan e Volkerink (2000) e Mulas-Granados (2003), que afirmam que a questão ideológica não afeta os resultados fiscais; Perotti e Kontopoulos (2002) apontam em sentido contrário.
} 
(GYÓRFFY, 2007, p. 27; PER MOLANDER, 2001, p. 23). Em outras palavras, as variáveis independentes (macroinstituições) não dariam conta de determinar satisfatoriamente as variáveis dependentes (resultados fiscais). Alega-se que esse é o motivo que deu origem ao surgimento da literatura institucionalista.

De acordo com a perspectiva adotada por este trabalho, entretanto, a principal lacuna dessa literatura política relaciona-se ao fato de que ela tende a ignorar que instituições políticas têm outros objetivos além da realização de determinados resultados fiscais. Ainda que tais resultados sejam importantes para inserção de um país no capitalismo mundial, as instituições discutidas são definidas e redefinidas em um embate democrático, que envolve disputas a respeito da cultura política compartilhada por uma população.

Em outras palavras, as instituições discutidas pela literatura política - assim como todas as outras que também podem ser relevantes para resultados fiscais - fazem parte do conjunto de instituições democráticas que estrutura um estado democrático de direito. Ainda que seja possível esclarecer quais são seus impactos sobre os resultados da política fiscal, isso não pode ser analisado sem que ao mesmo tempo se reflita tanto sobre as condições nas quais os próprios resultados fiscais são desejados e alcançados por uma determinada sociedade quanto sobre o contexto em que essas instituições foram definidas. Pode-se dizer que uma investigação interessada nessas questões estaria preocupada com a qualidade democrática dessas condições e instituições que definem a gestão da política fiscal.

Um breve exemplo pode facilitar a compreensão dessa observação. Em tese, é possível defender - concordando com a maior parte da literatura discutida até aqui - que seria desejável a um país ter instituições que permitissem ajustes fiscais mais facilmente de serem alcançados do que instituições nas quais os ajustes são mais difíceis e raros. Na prática, contudo, se a realização de tal ajuste fiscal implica desrespeitar direitos de minorias defendidos por um sistema eleitoral multipartidário ou, ainda, implica reduzir salários e pagamento de pensionistas e aposentados protegidos por uma constituição ou por um governo de coalizão, talvez não seja tão fácil decidir qual é o melhor modelo a ser adotado. Este exemplo demonstra as limitações de uma reflexão que simplesmente apresenta correlações e/ou causalidades entre sistemas eleitorais, formas de governo e tipo de governo (coalização, minoria ou unipartidário) e a política fiscal: ela obscurece correlações e causalidades entre as primeiras variáveis e outras que talvez sejam muito 
mais centrais para uma democracia do que a política fiscal. Essa reflexão voltará a ser apresentada na última seção (1.3.) desse capítulo.

De qualquer modo, ainda que as pesquisas discutidas nesta subseção sejam inconclusivas até o momento, elas apresentam sugestões que podem ser incorporadas a um estudo que contemple essas críticas.

\subsubsection{A literatura institucionalista}

O segundo grande grupo de literatura que discute os impactos das instituições, regras e princípios orçamentários sobre a política fiscal apresenta resultados empíricos mais conclusivos e busca explicar as variações encontradas em países que possuem macroinstituições semelhantes e mesmo assim apresentam resultados fiscais diferentes (GYÓRFFY, 2007, p. 27; PER MOLANDER, 2001, p. 23). A chamada literatura institucionalista pode ser interpretada como um desenvolvimento da literatura política, na tentativa de ajustar as variáveis dependentes (resultados fiscais) às variáveis independentes (definição mais precisa das instituições).

É possível dividir a literatura institucionalista em duas grandes linhas de pesquisa: uma de preocupação teórica e outra de preocupação empírica. ${ }^{25}$ Essas linhas de pesquisa se comunicam. A linha teórica desenvolve abstratamente fenômenos hipotéticos que poderiam impactar a natureza do processo orçamentário e a qualidade dos resultados fiscais, assim como busca discutir soluções institucionais hipotéticas que poderiam resolver tais problemas. A linha empírica apresenta índices numéricos que avaliam a relação entre instituições orçamentárias efetivas e resultados físcais encontradas em diversos países, geralmente por meio de estudos comparativos.

Per Molander apresenta um sumário de cinco categorias de problemas teóricos que estariam presentes nas decisões orçamentárias e que foram discutidos na literatura institucionalista (2001, p. 25). Essas categorias de problemas são: (i) agregação de preferências entre indivíduos completamente informados; (ii) situações em que o dilema do prisioneiro está presente - o problema da fonte comum de recursos (common pool); (iii) decisões que devem considerar o horizonte temporal; (iv) decisões em contextos de incerteza; (v) conflitos entre principal-agente. ${ }^{26}$ Molander esclarece que essa lista não é

\footnotetext{
${ }^{25}$ A divisão também é adotada nos trabalhos de Giuberti (2012, p. 158) e Dabla-Norris et al. (2010).

${ }^{26}$ Giuberti (2012) e Dabla-Norris et al. (2010) enfatizam somente dois dos cinco problemas apresentados por Molander, o problema da fonte comum dos recursos e o problema do principal agente. Gyorffy (2007) reproduz as cinco categorias de problemas apresentadas por Per Molander.
} 
exaustiva, mas abrange grande parte das controvérsias teóricas a respeito de decisões coletivas que já foram desenvolvidas.

Para Per Molander, o problema da agregação de preferências entre indivíduos completamente informados decorre do teorema da impossibilidade, que estabelece, em síntese, que, em contextos nos quais decisões envolvam mais de uma alternativa, a regra da maioria não necessariamente garante um resultado estável e situações de não decisão são plenamente possíveis $\left(2001\right.$, p. 26). ${ }^{27}$ No campo das decisões orçamentárias, esse problema se apresenta de modo especialmente claro, uma vez que cada um dos agentes públicos responsáveis por decidir questões orçamentárias pode ter uma preferência distinta de forma que o procedimento de voto afetaria consideravelmente o resultado final, gerando situações de instabilidade. Nesse contexto, regras procedimentais deveriam ser repensadas para evitar tais situações.

Um exemplo bem simples do problema discutido é o de um parlamento hipotético no qual decisões orçamentárias fossem tomadas por maioria simples dos votos de 100 parlamentares. ${ }^{28}$ Imaginando que cada parlamentar tivesse uma preferência distinta a respeito das prioridades orçamentárias, dentre as mais de 1000 opções orçamentárias geralmente disponíveis em um orçamento público, é fácil supor que a agregação dessas preferências individuais seria extremamente complexa, se não impossível.

Per Molander sugere duas soluções institucionais para situações como essa: (i) a redução do número de opções nas decisões orçamentárias; (ii) a imposição de uma ordem de votação que gerará necessariamente uma única alternativa vencedora, o que é feito às custas de dar maior poder àquele que detém o poder de agenda de definição da ordem de votação.

O segundo problema teórico de decisões orçamentárias desenvolvido por Per Molander é o da fonte comum dos recursos. Neste caso, a ideia central é que indivíduos, em certas decisões que também impactam o coletivo, podem ser incentivados a simplesmente buscar a maximização da sua utilidade individual, sem internalizar o custo dessa decisão para as demais pessoas. O raciocínio é semelhante ao do problema das externalidades, muito comum no debate econômico.

\footnotetext{
${ }^{27}$ O teorema da impossibilidade rendeu a Arrow um prêmio Nobel de economia. O teorema, que na realidade é um desenvolvimento de um insight original do Marques de Condorcet, tem diversas implicações, inclusive quanto à teoria democrática e ao desenvolvimento de uma teoria da justiça. Não há necessidade de desenvolvê-lo aqui. Ver: Arrow (1951) para a apresentação do teorema.

${ }^{28}$ Esse exemplo é desta pesquisa e não está desenvolvido no texto de Molander.
} 
A ideia de fonte comum dos recursos é o tipo de situação que talvez seja mais fácil de ser exemplificado em decisões orçamentárias, uma vez que o incentivo ao gasto público quase nunca gera a internalização do seu custo pelos promotores da despesa, em especial porque o orçamento é financiado pela coleta de impostos de todas e todos e pela emissão de títulos da dívida, mas o gasto público tende a beneficiar somente uma parcela da população.

Nesse caso, Per Molander apresenta três soluções logicamente possíveis para o problema da fonte comum de recursos: a situação é tal que os atores passam a considerar seus interesses de longo prazo e começam a cooperar; caso contrário, eles precisam ser forçados a agir contra seus próprios interesses individuais, seja por meio de uma norma que todos devam respeitar na tomada de decisão, seja por meio de uma cooperação forçada. Percebe-se a semelhança entre essas propostas e a história de Ulisses, que teve que se amarrar à haste de seu navio para poder resistir ao canto das sereias e assim prosseguir viagem: uma das ideias defendidas é a criação de normas que ajam contra os interesses individuais dos responsáveis pelas tomadas de decisão fiscal. Esse ponto será aprofundado nos próximos parágrafos e ao longo desta dissertação, uma vez que explicita como o direito pode servir para impor limites às deliberações sociais sobre política fiscal.

O terceiro problema discutido é o do horizonte temporal de decisões. Per Molander afirma que há uma tendência de sobrevalorização de benefícios do curtoprazo e da subestimação dos custos de longo prazo na tomada de decisões individuais. No campo fiscal, essa preocupação é expressa, por exemplo, pelas questões levantadas por Buchanan e Wagner (1977) e apresentadas na seção anterior deste capítulo. O que complicaria ainda mais essa discussão é que as decisões sobre política físcal não afetariam somente decisões futuras de um mesmo indivíduo, mas de indivíduos que sequer estão vivos no tempo presente.

Segundo Per Molander, o problema teórico do horizonte temporal explicita como nenhum outro a questão de que a escolha de regras orçamentárias é uma discussão sobre dilemas de contenção de si mesmo, como no caso de Ulisses e das sereias. Tratase de criar, como nas decisões constitucionais, instituições que impeçam certas opções no caso da política fiscal, opções orçamentárias - que possam afetar decisões futuras (2001, p. 29). Uma das soluções, portanto, seria criar comprometimentos com metas mensuráveis da política fiscal preocupadas com o futuro dessa política (2001, p. 30). 
O quarto problema teórico de decisões orçamentárias apresentado por Per Molander é o das decisões em situações de incerteza ou em situações de ignorância. Per Molander entende que decisões em situações de incerteza geram outros problemas ou erros na tomada de decisão: tendência de superestimar exemplos específicos e não correspondentes à situação enfrentada; dificuldade de interpretar novas situações adaptando o conhecimento existente aos fatos novos, mas antes tentando ancorar os fatos a ideias pré-concebidas; tendência de sobrevalorizar perdas em relação a ganhos, o que privilegia a manutenção do status quo. A situação de ignorância é outra: o agente público que decide pode não ter o conhecimento básico a respeito do tema sobre o qual está decidindo (2001, p. 31).

Para os dois tipos de problema, Per Molander indica que a solução é a informação. Não somente a disponibilização de informação, mas também a criação de procedimentos que forcem os agentes públicos a adquirirem novos conhecimentos e a desenvolverem uma maior compreensão das implicações de várias alternativas de ação. No caso da política fiscal, Per Molander sugere que isso pode ser feito tanto ex ante, com a publicação de informações que considerem diferentes cenários das opções fiscais, como ex post, com instituições que avaliem e auditem informações após as tomadas de decisão.

A última categoria de problema teórico de decisões orçamentárias desenvolvida por Per Molander decorre do modelo principal-agente, segundo o qual, em certas situações, o agente tenderia a agir contra ou a despeito das preferências do principal. Em outras palavras, não são somente as preferências do principal que importam nas tomadas de decisão do agente. $\mathrm{O}$ agente também tem suas próprias preferências, que afetam consideravelmente a tomada de decisão. No campo fiscal, isso é mais do que evidente se considerarmos as diversas cadeias que se formam, desde a preferência dos cidadãos que em tese deveriam ser essenciais nas decisões orçamentárias - até os agentes públicos responsáveis pelas decisões orçamentárias (seja no Executivo, seja no Legislativo).

As soluções propostas para o problema do modelo principal-agente, segundo Per Molander, são amplamente conhecidas: um contrato transparente e completo entre agente e principal, a troca integral de informações - para evitar assimetrias - e mecanismos efetivos de prestação de contas. O suposto contrato entre eleitores e políticos, contudo, é necessariamente incompleto em uma democracia representativa. Ainda assim, Per Molander sugere que sistemas de auditoria e avaliação das decisões, 
eleições periódicas e a possibilidade de demissão dos agentes públicos responsáveis pelas decisões mais importantes são duas soluções possíveis especialmente para facilitar a troca de informações e criar mecanismos mais efetivos de prestação de contas.

A linha de pesquisa empírica da literatura institucional geralmente desenvolve métodos de avaliação das instituições orçamentárias existentes e de seus impactos nas decisões fiscais a partir desses insights teóricos - que são mais ou menos desenvolvidos a depender da pesquisa empírica que se analisa. As ideias precursoras dessa linha empírica podem ser encontradas nos textos de Von Hagen (1992), Von Hagen e Harden (1996) e Alesina e Perotti (1995, 1996).

A questão da literatura institucionalista empírica é diferente da questão da literatura política apresentada na seção anterior porque ela discute em detalhes o processo deliberativo das decisões orçamentárias, com destaque para as regras que o estruturam, e seus efeitos para decisões fiscais. Como consequência do detalhamento, a linha de pesquisa empírica enfatiza discussões sobre regras e princípios orçamentários que definem os procedimentos de elaboração, aprovação, execução e avaliação do orçamento, além de regras e princípios que estabeleçam metas para a gestão das receitas e das despesas do estado como um todo (GIUBERTI, 2012, p. 159). É por esse motivo que alguns autores se referem a essa literatura como "microinstitucionalista" (CORREA, 2007).

A partir de diferentes metodologias e recortes empíricos, a literatura conclui que “instituições orçamentárias mais hierárquicas/centralizadas e mais transparentes resultam em maior disciplina fiscal" (GIUBERTI, 2012, p. 160). ${ }^{29}$ Para os fins deste trabalho, serão apresentados em detalhes os resultados de somente duas pesquisas, que servem como exemplo das conclusões da literatura: Alesina et al. (1999) e DablasNorris et al. (2010) - essa escolha segue Giuberti (2012), que discute e usa as metodologias empregadas pelas duas pesquisas para analisar as instituições orçamentárias brasileiras no período entre 1965-2010.

Alesina et al. concluem que "procedimentos e instituições orçamentárias têm impacto significativo nos resultados fiscais" (ALESINA et al., 1999, p. 4, tradução

\footnotetext{
${ }^{29}$ Além dos dois trabalhos que serão apresentados nesta seção, Hallerberg et al. (2009) estudam os países europeus; Perotti e Kontopoulos (2002) estudam os países da OCDE; Gleich (2003), Fabrizio e Mody (2006) e Mulas-Granados et al. (2009) estudam países do leste europeu; Filc e Scartascini (2007) ampliam o estudo de Alesina et al. para os países da América Latina e Prakash e Cabezón (2008) estudam os países da África subsaariana fortemente endividados.
} 
nossa). ${ }^{30}$ Os autores apresentaram um estudo comparado e qualitativo baseado em 10 questões que foram feitas a servidores públicos de 20 países da América Latina. ${ }^{31}$ Essas questões tinham o mesmo peso e derivavam de três hipóteses dos autores: (i) leis que estabeleciam constrangimentos ex ante nos déficits conduziriam a maior disciplina fiscal; (ii) regras procedimentais hierárquicas conduziriam a maior disciplina fiscal; (iii) procedimentos transparentes levariam a maior disciplina fiscal (1999, p. 4).

Após receberem as respostas, os pesquisadores as analisaram em conjunto com os indicadores econômicos e fiscais disponíveis para os países estudados e concluíram que:

um país com instituições orçamentárias que contenham significativas restrições ao déficit, que sejam hierárquicos e mais transparentes, podem ter a expectativa de gerarem déficits primários 2.9 pontos percentuais mais baixos que países com poucas restrições, não hierárquicos e com procedimentos orçamentários menos transparentes. (1999, p. 15, tradução nossa) ${ }^{32}$.

De modo semelhante a Alesina et al. (1999), Dablas-Norris et al. (2010) também realizaram questões a gestores públicos de diferentes países (nesse caso, de países de baixa e média renda) para análise das instituições orçamentárias. Os autores modificaram e ampliaram o número de questões apresentadas aos servidores públicos de 20 para 35, subdividindo-as conforme uma análise do processo orçamentário em três diferentes etapas: planejamento e negociação; aprovação; implementação - que na visão dos autores abrange a fase de avaliação da política. Em cada uma dessas três fases, os autores avaliam cinco diferentes categorias: existência de procedimentos hierárquicos; a existência de regras e controles; preocupações com sustentabilidade e credibilidade; abrangência do processo orçamentário; transparência.

No nível geral, os autores concluem que há uma relação positiva entre instituições orçamentárias de um país e sua performance fiscal mensurada em termos de disciplina fiscal, ou seja, da capacidade de gerar déficits menores e possuir dívidas também menores. Desagregando os resultados, argumentam que a fase de planejamento

\footnotetext{
${ }^{30}$ No original: "budget procedures and budget institutions have significant impact on fiscal outcomes". Para pesquisas e resultados semelhantes, ver: Filc e Scartascini (2004) e Campos e Pradhan (1996).

${ }^{31}$ Para uma discussão detalhada dessa metodologia em português, ver Giuberti (2012, pp. 162-178).

${ }^{32}$ No original: "on average, a country with budgetary institutions which contain important constraints on the deficit, are more hierarchical and more transparent can be expected to have primary deficits 2.9 percentage points lower than a country with few constraints, and collegial and less transparent budget procedures."
} 
e negociação do orçamento é provavelmente a mais importante em termos de resultados fiscais e que as categorias de abrangência e transparência são as mais relevantes para os resultados primários e para o endividamento público. Os autores também alegam ter encontrado evidências de que as instituições orçamentárias, em especial nas fases iniciais do orçamento, podem ser responsáveis por evitar um comportamento pró-cíclico por parte do governo no enfrentamento de crises.

Esta dissertação não tem a mesma preocupação das pesquisas da literatura institucionalista, seja na vertente empírica ou teórica, porque busca dar centralidade as discussões democráticas por trás das instituições fiscais e dos resultados da política fiscal. Contudo, as conclusões desses estudos não devem ser ignoradas. As pesquisas podem e devem ser levadas em consideração quando for apresentada a reforma do regime jurídico da política fiscal no Brasil, no capítulo três, e em especial na discussão dos impactos da reforma na política fiscal, no capítulo quatro.

O diálogo que pode ser estabelecido entre esta pesquisa e a literatura institucionalista não é somente de intercâmbio de conclusões - como já sugerido na subseção anterior, quando foi discutida a literatura política. O diálogo também pode ser epistemológico e metodológico. As pesquisas discutidas até aqui tendem a ignorar impacto de transformações sociais mais amplas sobre a política fiscal, o papel dessas instituições na legitimação de certos objetivos fiscais e questões sobre a cultura política de uma sociedade e sua relação com decisões orçamentárias e relativas ao endividamento público. Uma pesquisa de direito e macroeconomia como a que propõe este trabalho não pode proceder da mesma maneira.

\subsection{Direito da macroeconomia em uma democracia}

Esta pesquisa pretende incorporar as reflexões e os estudos apresentados até aqui em um projeto que os modifica em dois diferentes sentidos: por um lado, pretende-se inseri-los em um campo de investigação mais amplo, que incorpore questões sobre legitimidade democrática da política fiscal; por outro lado, ela se pretende menos abrangente, porque um estudo que incorpora questões sobre legitimidade democrática de uma política exige do pesquisador a análise aprofundada das dinâmicas política, social e econômica de uma sociedade, o que não parece permitir a produção de pesquisas que envolvam mais de alguns poucos países - em especial em uma pesquisa individual. 
Como já mencionado, entende-se que a análise do regime jurídico de qualquer política estatal em uma democracia permite o acesso a disputas sociais sobre essa política. Ou seja, defende-se que uma pesquisa que tenha por objeto o regime jurídico da política fiscal permite compreender e interpretar ambições normativas compartilhadas socialmente a respeito da gestão das receitas e das despesas do estado, e como tem ocorrido a promoção ou o bloqueio dessas ambições.

A ideia de que o estudo do direito permite acesso a disputas sociais sobre uma política em uma democracia implica sustentar que o direito é a forma por excelência de legitimação democrática das políticas de um estado moderno. Talvez essa ideia seja mais facilmente compreendida no âmbito do direito constitucional. É possível defender, por exemplo, que revoluções modernas bem sucedidas se legitimaram com a elaboração de uma constituição escrita que estabeleceu procedimentos democráticos ou ao menos com o estabelecimento de regras claras - válidas para todas e todos, ainda que não escritas - a respeito da gestão democrática do poder político. Em outras palavras, reivindicações pelo estabelecimento de uma ordem social legítima na modernidade foram geralmente traduzidas em uma forma jurídico-constitucional que estabeleceu procedimentos democráticos para o exercício do poder político. ${ }^{33}$

A análise de uma política macroeconômica da perspectiva de direito e macroeconomia em uma democracia, contudo, é distinta da sugestão sobre direito constitucional e legitimidade democrática que se discutiu no parágrafo anterior. É completamente possível imaginar e defender que o direito não reflete disputas sociais a respeito da gestão da economia na modernidade, mesmo que eventualmente se concorde com a hipótese de que a democracia constitucional é a forma de legitimidade por excelência dos estados modernos.

É possível imaginar duas diferentes interpretações segundo as quais o estudo de um regime jurídico não permitiria o acesso a disputas sociais sobre uma política econômica.

A primeira linha de interpretação sustentaria que a economia moderna se desenvolve perfeitamente caso seja autônoma da política e de outras considerações de ordem não econômica. De acordo com essa interpretação, a economia funcionaria

\footnotetext{
${ }^{33}$ Não é conveniente desenvolver em detalhes essa discussão, que poderia ser interpretada como um projeto de pesquisa longo e duradouro e que, provavelmente, restaria inconcluso. Essas reflexões sobre legitimidade da democracia constitucional moderna derivam de uma possível interpretação das teses de Max Weber e Jürgen Habermas a respeito da legitimidade democrática da ordem social moderna. Sobre o assunto, ver o capítulo 2 do texto Facticidade e Validade, de Jürgen Habermas.
} 
perfeitamente quando fossem respeitadas condições que a estruturasse como uma esfera autônoma de relações sociais, orientadas somente por cálculos individuais racionais relacionados ao ganho utilitário do indivíduo. A política fiscal, como um dos elementos de gestão econômica, sempre apresentaria uma opção tecnicamente correta e outras opções equivocadas. A ideia de disputa social sobre uma política econômica, portanto, não faria sentido.

Dessa perspectiva, o regime jurídico da política fiscal expressa somente uma destas duas opções: (i) ou ele é garantia da autonomia da economia em relação a outras "esferas" sociais - regras e princípios jurídicos que impeçam "intervenções na economia"; (ii) ou o regime jurídico é expressão da intromissão indevida de imperativos políticos, morais e sociais na esfera econômica - e na política fiscal - razão pela qual deve ser rejeitado ou reformado.

Uma segunda linha de interpretação é analisar o desenvolvimento da economia moderna como a estruturação de relações sociais marcadas intrinsecamente pela exploração, uma vez que determinados indivíduos ou grupos sociais detentores de certos recursos estratégicos irão necessariamente explorar os demais indivíduos e grupos sociais, não detentores desses recursos. A política fiscal, nesse caso, é somente mais um dos instrumentos usados para manter essa exploração estrutural. O regime jurídico como um todo, por sua vez, é interpretado como um dos elementos fundadores e garantidores dessa estrutura injusta, inclusive quanto ao caso do regime jurídico da política fiscal. Somente a subversão da estrutura acabaria com a exploração e essa subversão provavelmente implicaria a rejeição do regime jurídico como um todo; qualquer discussão que não envolvesse a subversão da estrutura injusta seria marginal.

Um possível desenvolvimento dessa segunda linha de interpretação afirmaria que, após o advento do estado de bem-estar social, na metade do século XX, a legitimação do estado moderno passou a depender da capacidade do estado mobilizar a economia para fornecer diretamente certos bens e serviços para cidadãs e cidadãos. $\mathrm{O}$ direito e a linguagem dos direitos teriam se tornado completamente desnecessários na legitimação da ordem social. De cidadãs e cidadãos, com direitos e deveres, os indivíduos modernos se tornariam consumidoras, consumidores e clientes do estado, que deve gerir a economia tecnicamente para fornecer determinados bens e serviços, independentemente da política e do direito. Em qualquer assunto econômico, quando muito, o direito funcionaria somente como um dos instrumentos do estado para a gestão técnica da economia. 
Para os fins deste trabalho, essas linhas de interpretação são desconsideradas como hipóteses porque reduzem a economia moderna a um conceito sistêmico que não é passível de alteração. Nessas interpretações, a economia independe das disputas políticas e sociais concretas que se desenvolvem na história. Descritivamente, elas compreendem a economia como sistema autônomo de relações sociais e enxergam as relações entre direito, política e economia como relações de exterioridade. Em outras palavras, elas afirmam que é possível interpretar relações sociais econômicas, políticas e jurídicas separadamente. Mesmo no caso da segunda linha de interpretação, esse raciocínio está presente: primeiro deve-se compreender a estrutura da produção econômica e das relações econômicas, para só depois serem incluídas nas análises as considerações de ordem política e jurídica. A compreensão das relações econômicas antecede conceitualmente a análise das relações políticas e jurídicas existentes.

O principal problema desse tipo de interpretação é que ele tende a apresentar respostas únicas e técnicas para questões econômicas, tanto no âmbito teórico quanto no âmbito prático. Nesse sentido, uma boa interpretação das relações econômicas permitiria esclarecer a resposta correta a ser fornecida a qualquer problema econômico enfrentado. Não há espaço para abranger interesses políticos e sociais, ou disputas entre grupos sociais, na compreensão das questões econômicas que se apresentam.

Esta pesquisa rejeita esse gênero de interpretação da economia, pois entende que todas as relações sociais - inclusive as econômicas - dependem do compartilhamento, implícito ou não, de expectativas e normas a respeito das ações sociais e de como se comportarão os agentes sociais. Esse compartilhamento intersubjetivo de expectativas sobre as relações sociais é sempre possível de ser explicitado e criticado. Em outras palavras, entende-se que relações econômicas imbricam-se a visões, valores e interesses políticos existentes em uma dada sociedade - estes em boa medida influenciados e moldados pelo direito - e que, por isso, não podem ser compreendidas isolada e aprioristicamente.

Na modernidade, em particular, o uso da forma jurídica se tornou um dos modos mais comuns de contestar e estabilizar certas expectativas sobre as relações sociais. Nesse sentido, esta pesquisa delimita o seu campo de investigação a partir da hipótese que políticas macroeconômicas também usam a tradução jurídica para se legitimarem em um contexto democrático, como é o caso brasileiro. Em outras palavras, regras e princípios jurídicos são utilizados para legitimar e efetivar opções políticas sobre 
macroeconomia em uma democracia; no caso, para estabilizar certas expectativas compartilhadas intersubjetivamente a respeito da política fiscal.

É por isso que se considera que esta pesquisa tem um ganho epistemológico em relação à literatura econômica apresentada na seção 1.1. Ao analisar uma política macroeconômica de uma perspectiva de direito da macroeconomia em uma democracia, as opções econômicas a serem definidas socialmente não são e nem poderiam ser delimitadas de antemão, pelo teórico ou economista. Se o direito é a forma de legitimação democrática de um estado moderno, regras e princípios jurídicos estruturam e deveriam estruturar procedimentos democráticos para a própria escolha dos objetivos sociais que, por sua vez, são reproduzidos por meio de determinadas escolhas macroeconômicas. Não houve e provavelmente não há uma única definição, correta e puramente técnica, anterior à própria deliberação social, sobre a política macroeconômica a ser adotada.

Nesse sentido, as diferentes correntes teóricas econômicas somente serviriam, à luz deste trabalho, para fomentar o debate público a respeito de diferentes opções na gestão das receitas e das despesas do estado. Elas podem e devem informar o debate mais amplo a respeito das consequências de certas escolhas sociais - uma vez que uma política macroeconômica é uma escolha social. No entanto, as teorias econômicas não definem por si mesmas essas escolhas; as escolhas sobre política econômica são sempre sociais, por sua própria natureza.

Por outro lado, uma perspectiva de direito e macroeconomia que se preocupa com a legitimidade democrática de um dos âmbitos da gestão macroeconômica da vida social abrange a literatura sobre impacto de regras e princípios jurídicos na política fiscal, discutida na seção 1.2., mas não se resume a ela. Essa literatura é essencial para entender alguns dos efeitos e objetivos da reforma do regime jurídico da política fiscal no país, mas também deve ser lida de forma a permitir que os próprios objetivos da política fiscal sejam vistos dentro de um processo constante de legitimação democrática.

Nesse contexto, é possível afirmar que este trabalho se inspira em dois diagnósticos sobre a pesquisa em direito, que são considerados complementares e esclarecem um pouco mais as ideias que estão sendo desenvolvidas até aqui.

O primeiro é o de que há uma lacuna de "pesquisa básica" em direito, tal como Nobre a definiu em seu texto Apontamentos Sobre a Pesquisa em Direito no Brasil, ainda em 2003. Por pesquisa básica, Nobre faz referência a pesquisas que tenham por objetivo descrever e compreender certos institutos jurídicos sem um posicionamento 
normativo a respeito de sua legalidade, constitucionalidade ou legitimidade (NOBRE, 2003).

Dado esse primeiro diagnóstico, que não será aprofundado aqui, esta dissertação não tem a intenção de apontar soluções para conflitos concretos e sequer tem um compromisso com a "decidibilidade", o que às vezes é até mesmo considerado o objeto próprio de uma pesquisa jurídica. Ao contrário, busca-se reconstruir as transformações do regime jurídico da política fiscal, colocando no centro da investigação as interpretações, regras e princípios que foram criados e mobilizados, sejam eles da esfera legal, administrativa, política ou jurisprudencial para modificar a política fiscal em um contexto democrático. Evitar-se-á ao longo dos capítulos uma tomada de posição normativa sobre a qualidade da reforma e dos discursos usados publicamente para justificá-la.

É importante salientar, contudo, que a realização dessa pesquisa básica exige a descrição sobre como diferentes discursos e práticas indicam ou indicaram caminhos distintos de reforma e gestão da política fiscal e como eles representam ou representaram conflitos concretos a respeito da legitimidade democrática da política fiscal. Afinal, faz parte de uma descrição de qualidade de qualquer instituto jurídico o mapeamento sobre quem e quais órgãos defendem determinados entendimentos a respeito desse instituto.

Acredita-se que aqui residam os potenciais crítico e normativo desta pesquisa. Ao fim de uma reconstrução que tenha por objetivo demonstrar como discursos e práticas indicam caminhos de reforma e estabelecem critérios normativos para o regime jurídico da política fiscal, talvez seja possível demonstrar que certas ambições normativas dos sujeitos engajados nas reformas não foram atendidas, o que aponta para uma agenda de novas reformas e disputas.

Nesse sentido, esta pesquisa não pretende apresentar em nenhum momento uma concepção única ou correta sobre democracia, o que implicaria incorrer em erro semelhante aos de estudos de economistas que entendem as políticas macroeconômicas sem qualquer reflexão sobre seu componente político e social. Na realidade, o objetivo da pesquisa é descrever como diferentes discursos econômicos a respeito do regime jurídico da política fiscal também se utilizaram e se basearam em regras e princípios jurídicos para se definirem como democráticos e como isso impactou a gestão da política fiscal. Talvez, ao final dessa descrição, seja até mesmo possível demonstrar que a concepção de democracia que subjaz ao regime jurídico da política fiscal seja muito 
distinta de diversas concepções de democracia que são compartilhadas por várias pessoas e grupos atualmente, embora isso não seja objeto de uma reflexão mais aprofundada nesta dissertação.

O segundo diagnóstico que inspira esta pesquisa é o de que o capitalismo contemporâneo tem passado por profundas transformações que impactam a capacidade dos Estados definirem autonomamente regimes jurídicos da gestão macroeconômica da sociedade, em especial após a recente crise econômica mundial. ${ }^{34}$ Isso impacta as instituições que estão e serão estruturadas para lidar com as tensões entre capitalismo e democracia, o que abre uma frutífera agenda de pesquisas no campo do direito, da sociologia, da ciência política, da economia e das relações internacionais.

Assim, este trabalho pretende demonstrar se e como o regime jurídico da política fiscal foi e ainda está sendo construído no Brasil em meio a discursos e práticas conflitantes, doméstica e internacionalmente, que apontam para reformas distintas de uma das ferramentas de gestão macroeconômica da sociedade, qual seja, a política fiscal. Essas reflexões, contudo, só poderão se desenvolver plenamente no fím do caminho que será percorrido ao longo dos próximos capítulos.

Os problemas de pesquisa ganham, portanto, novos contornos após a exposição deste capítulo. As questões "o que é", "como foi reformado" e "quais foram os impactos" do regime jurídico da política fiscal no país passam a ser analisadas de uma perspectiva de legitimação democrática, para além das motivações "puramente" jurídicas ou econômicas que geralmente mobilizam pesquisas sobre o tema. $\mathrm{O}$ regime jurídico da política fiscal, dessa perspectiva, pode servir tanto para permitir que correntes econômicas fomentem o debate público e o engajamento nas diferentes opções disponíveis, das mais diversas maneiras, quanto para promover algumas delas explicitamente ou não - em detrimento de outras.

A pesquisa da reforma e dos impactos do regime jurídico da política fiscal no Brasil pode ser interpretada, assim, como uma tentativa de esclarecer o papel que o direito cumpriu no país nas últimas décadas em relação às opções de política fiscal existentes em uma democracia. É o que se analisará nos próximos capítulos.

\footnotetext{
${ }^{34}$ Ver, entre outros: Teubner (2011), Unger e Lothian (2011), Veiga da Rocha (2011) e Faria (2011).
} 


\section{Capítulo 2 - Um novo regime jurídico da política fiscal no Brasil}

Este capítulo propõe uma organização de regras e princípios jurídicos que constituem o que esta pesquisa chamou de regime jurídico da política fiscal no Brasil, ao longo do capítulo 1. Serão enfatizados regras e princípios jurídicos aprovados na década de 1990 e consolidados com a aprovação da Lei de Responsabilidade Fiscal, sancionada em maio de 2000. A principal hipótese é que, nessa década, houve um uso explícito e consciente do regime jurídico para promoção de determinada agenda de política fiscal no país.

$\mathrm{Na}$ realidade, a reforma do regime jurídico da política fiscal se iniciou na década de 1980, com o processo de unificação orçamentária, o fim da Conta Movimento entre Banco do Brasil e Banco Central e a criação da Secretaria do Tesouro Nacional (STN), entre outras medidas que serão discutidas abaixo. ${ }^{35}$ Esta pesquisa interpreta que o principal objetivo da reforma, naquele período, era de instituir mecanismos que permitissem ao governo federal ter conhecimento sobre a situação das finanças públicas no país, além de estabelecer condições de controle dos gastos públicos e da participação do Legislativo nas discussões orçamentárias.

Em comparação, a partir da Constituição Federal de 1988, a reforma do regime jurídico se intensificou com a aprovação de regras e princípios que explicitamente promoviam a agenda do ajuste fiscal no país. Questões sobre a solvência do estado brasileiro e sobre a sustentabilidade da dívida pública passaram a ser a dominar os discursos sobre a reforma do regime jurídico da política fiscal. Dentre outras leis que foram criadas no período, para além da Lei de Responsabilidade Fiscal, destacam-se as Leis Camata I e II, de 1995 e 1999, que impuseram limites aos gastos públicos com pessoal, diversas leis de reestruturação das dívidas estaduais, que culminaram na última lei do gênero em 1997, e a Medida Provisória que pela primeira vez criou metas explícitas de superávit primário para o governo federal, em 1998. Como se demonstrará, não foram somente leis que estruturaram regras e princípios jurídicos para uma política fiscal ligada à agenda do ajuste. Resoluções do Senado Federal e decisões do Supremo Tribunal Federal (STF) também foram essenciais no processo.

\footnotetext{
${ }^{35}$ Guardia (1992, p. 7) e Filc e Scartascini (2007, p. 158) argumentam que as reformas das instituições fiscais se iniciaram em 1985, tanto no Brasil, no caso de Guardia, como na América Latina como um todo, no caso de Filc e Scartascini.
} 
Com o objetivo de apresentar esse novo regime da política fiscal no país, construído na década de 1990 a partir das bases estabelecidas na década de 1980, o capítulo está divido da seguinte forma: a próxima seção resume as principais mudanças advindas da reforma das finanças públicas da década de 1980, conectando-as a um debate sobre a ausência do objetivo de promoção da agenda do ajuste fiscal (seção 2.1.). Na sequência, são apresentadas as principais alterações das regras e dos princípios jurídicos promovidas na década de 1990, organizando-as em quatro níveis distintos: relação federativa; relação entre Legislativo e Executivo; limitações à política fiscal do setor público consolidado; regras de transparência (seção 2.2.).

A última seção deste capítulo relaciona a organização da reforma do regime jurídico da política fiscal com a literatura sobre regras fiscais apresentada no capítulo 1. Argumenta-se que a moldura jurídica resultante da reforma não pode ser compreendida somente a partir da discussão macroeconômica, o que demonstrará a importância do capítulo 3, que reconstrói os contextos político e econômico que culminaram na aprovação da Lei de Responsabilidade Fiscal no ano 2000. Também será apresentada a hipótese que conduzirá parte considerável dos esforços do capítulo 4: embora conectada à agenda do ajuste fiscal, a reforma do regime jurídico da política fiscal talvez não tenha eliminado a discricionariedade dos agentes públicos responsáveis pelas decisões centrais dessa política (seção 2.3).

\subsection{As reformas legais e institucionais da política fiscal na década de 1980: criação simultânea das autoridades fiscal e monetária ${ }^{36}$}

A década de 1980 foi um período de intensa reforma jurídica das finanças públicas no Brasil. Para compreender a relevância da reforma promovida, é necessário

\footnotetext{
${ }^{36} \mathrm{O}$ estudo mais completo sobre as reformas realizadas na década de 1980, até hoje, é o que resultou na tese de doutorado de Gilda Gouvea, na Universidade de Campinas, em 1994, publicada em livro no mesmo ano (esta pesquisa se utilizou da tese de doutorado da autora: GOUVEA, 1994). Esta seção se baseia em grande parte nos achados daquela pesquisa, embora incorpore também literatura mais recente sobre o tema. É importante ressaltar que algumas vezes as reformas da década de 1980 são analisadas somente da perspectiva de uma reorientação institucional do setor financeiro, como uma finalização da reforma iniciada em 1964 com a criação do Banco Central. Contudo, na linha de Nóbrega e Loyola in Sola e Whitehead (2006), esta pesquisa interpreta aquelas reformas como a construção conjunta das autoridades fiscal e monetária no país. Uma pesquisa futura pode tentar compreender como o regime jurídico da política fiscal criado na década de 1960, em especial a partir da aprovação da Lei $\mathrm{n}^{\circ} 4.320$, de 17 de março de 1964, se conecta com as reformas das décadas de 1980 e 1990 e como a análise do regime jurídico da política fiscal pode complementar a análise das regras e princípios sobre política monetária. Esta pesquisa, contudo, optou por analisar somente a reforma do regime jurídico da política fiscal nessas duas décadas, excluindo a discussão das regras e princípios anteriores e do regime jurídico da política monetária.
} 
identificar, ainda que em linhas gerais, o arranjo institucional que vigorava anteriormente. A partir da apresentação desse arranjo, serão organizadas as regras e princípios jurídicos criados ao longo da segunda metade da década, primeiro no âmbito do Executivo, entre os anos de 1985 e 1987, e, na sequência, no âmbito legislativoconstitucional, entre 1987 e 1989.

Esta pesquisa sustenta que essas regras e esses princípios contribuíram na construção simultânea das autoridades monetária e fiscal no país. No âmbito da política fiscal, as regras e os princípios centralizaram o poder fiscal no Ministério da Fazenda e na Secretaria do Tesouro Nacional, o que serviu de base à atribuição de competências orçamentárias específicas ao Executivo e ao Legislativo; unificaram os orçamentos existentes; e criaram regras para facilitar o controle do gasto e do endividamento público pelas autoridades públicas federais.

\subsubsection{O desenho das finanças públicas no início da década de 1980}

Antes da reforma das finanças públicas na década de 1980, o Brasil contava com uma multiplicidade de autoridades fiscais, sem que houvesse mecanismos de prestação de contas efetivos para todas elas. Banco Central, Conselho Monetário Nacional, Banco do Brasil e Ministério da Fazenda compartilhavam a capacidade de gerar gasto e endividamento público, geralmente sem ter que prestar contas à sociedade, ao Legislativo ou a qualquer outro poder ou instituição a respeito de suas práticas. O Banco Central e o Conselho Monetário Nacional detinham poder fiscal por meio do orçamento monetário e da administração dos títulos da dívida do Tesouro Nacional; o Banco do Brasil exercia poder fiscal, na prática, por meio da Conta Movimento compartilhada entre ele e o Banco Central; e o Ministério da Fazenda detinha poder fiscal para gerir os recursos discutidos no Orçamento Fiscal aprovado no Legislativo.

A elaboração do orçamento monetário era - e ainda é - uma das competências legais do Banco Central, a ser aprovado pelo Conselho Monetário Nacional. ${ }^{37} \mathrm{O}$ orçamento monetário pode ser resumido como a previsão do balanço das contas públicas nacionais, incluindo previsões sobre os resultados fiscais e do balanço de pagamento, para fins de indicação de possíveis desenvolvimentos monetários (KNIGHT, 1959, p. 210) ou da estimativa das necessidades globais de moeda e crédito, nos termos da lei. Nesse sentido, o orçamento monetário é um dos instrumentos da

\footnotetext{
${ }^{37}$ Inciso III do artigo $4^{\circ}$ da Lei $4.595 / 1964$.
} 
política monetária do Banco Central. Ele projeta a eventual injeção da quantidade de meios de pagamento (moeda) suficiente para manter um determinado nível de crescimento econômico e estima a expansão do crédito público e privado.

Em termos fiscais, o orçamento monetário brasileiro tinha a característica peculiar de também ser utilizado pelo Banco Central para subsídio da agricultura e da indústria (TAVARES, 2005, p. 81) e às exportações (ABRUCIO e LOUREIRO, 2002, p. 9), como um típico instrumento de fomento de crédito, até o fim da década de 1980. Esses subsídios, por serem elaborados pelo Banco Central e aprovados pelo Conselho Monetário Nacional, não entravam no orçamento fiscal elaborado pelo Executivo e discutido pelo Legislativo. Eles constavam somente no orçamento monetário. Gouvea resume bem o seu funcionamento:

[o orçamento monetário] não era propriamente um orçamento, mas sim uma previsão da variação anual dos saldos das contas de recursos e aplicações das autoridades monetárias, compatível com uma "desejada" expansão dos meios de pagamento, definida pelo Conselho Monetário Nacional. Mas a expressão ganhou materialidade tão grande, que passou a ser utilizada pelo governo, por seus técnicos e mesmo por vários economistas, quando se referiam a "uma operação financiada por recursos financeiros pelo Orçamento Monetário", como se o Orçamento Monetário - que é uma equação contábil - gerasse recursos. Na realidade, tirar recursos do Orçamento Monetário significava dizer que os recursos não-monetários não davam lastro suficiente para financiar todas as operações ativas, e que, portanto, era necessário o apelo à emissão de títulos para financiar a dívida ou à emissão de moeda para sustentar uma nova operação (GOUVEA, 1994, pp. 115-116)

Em outras palavras, o Orçamento Monetário não era usado somente para projetar a emissão de moeda na economia a partir da previsão de certo nível de atividade econômica. Ele também era usado para financiar operações ativas, o que implicava aumento do endividamento ou emissão de moeda.

Mais especificamente, o Orçamento Monetário era usado para duas funções: concessão de subsídios diretos ao setor privado e despesas com previsão de retorno. Essas funções, tipicamente fiscais, não eram previstas no Orçamento Fiscal. São exemplos das atividades que eram financiadas por meio do Orçamento Monetário: 
aquisição de produtos agrícolas, comercialização de trigo e formação de estoques reguladores (GUARDIA, 1992, p. 13).

O Banco Central ainda concentrava outra competência fiscal: ele detinha o poder de emitir e administrar a dívida pública do Tesouro Nacional. Isso significa dizer que o Banco Central determinava os prazos e as remunerações dos títulos da dívida pública, com o objetivo de controlar a liquidez da economia (TAVARES, 2005, p. 81). Nesse sentido, seja por meio do orçamento monetário, seja por meio da administração dos títulos do Tesouro Nacional, é possível afirmar que o Banco Central atuava na prática como autoridade fiscal e monetária simultaneamente.

O Banco Central não foi a única autoridade fiscal e monetária do país na década de 1980. O Banco do Brasil poderia de fato emitir moeda e estimular despesas sem passar por qualquer aprovação externa, mesmo do Banco Central ou do Ministério da Fazenda, por meio da gestão da Conta Movimento. ${ }^{38}$ A Conta Movimento foi um dos principais instrumentos das políticas monetária e fiscal no Brasil ao longo das décadas de 1960, 1970 e 1980, quando finalmente ela foi encerrada por meio de diferentes decisões do Conselho Monetário Nacional entre 1984 e 1986, e foi criada a conta única do Tesouro Nacional junto ao Banco Central.

A Conta Movimento foi criada pouco após o surgimento do Banco Central, em 1965, e tinha como objetivo facilitar a contratação de serviços e outras despesas para o novo órgão. ${ }^{39}$ Como explica Gouvea (1994, pp. 117-120), o Banco Central não tinha recursos para operar em 1965. Dessa forma, a Conta Movimento entre ele e Banco do Brasil serviria como a fonte de custeio de suas despesas administrativas em um período inicial, "até que o Banco Central tivesse fontes de receita próprias para fazer frente" (1994, p.120) a essas despesas.

\footnotetext{
38 Como alertam Abrucio e Loureiro (2002, p. 8), a existência dessa conta só pode ser compreendida no contexto de criação do BCB pela Lei no 4.595/1964, ainda na ditadura militar. Antes da criação do BCB, era o BB que exercia o papel de única autoridade monetária no país, por meio da Superintendência da Moeda e do Crédito (SUMOC). Ao longo das duas primeiras décadas de funcionamento do BCB, o BB impediu a centralização da autoridade monetária no BCB, o que também acabou por influenciar a gestão da política fiscal. Entre 1964 e a segunda metade da década de 1980, o governo brasileiro contava na prática com duas autoridades monetárias: o BB e o BCB. E com nenhuma autoridade fiscal definitiva, já que o país tinha ao menos três orçamentos, sendo que somente um deles era submetido ao controle do Congresso Nacional. Sobre a Conta Movimento e a criação do BCB, ver também Taylor (2009) e Nóbrega e Loyola in Sola e Whitehead (2006).

${ }^{39}$ Segundo Gouvea, o documento que criou a Conta Movimento do Banco Central no Banco do Brasil foi uma Carta/Nota Reversal, aprovada pelo conselho da SUMOC, em 29 de março de 1965. Em tese, os "saldos credores seriam recolhidos diariamente pelo Banco do Brasil ao Banco Central (o que nunca aconteceu) e seus saldos devedores seriam recompensados nas operações de redesconto e sobre eles recairiam juros de 1\%" (GOUVEA, 1994, p. 118).
} 
Na prática, contudo, o saldo do Banco Central na conta de movimento foi sempre credor e o crédito em seu favor não era executado. Isso porque quem passou a se utilizar da conta para executar tanto políticas de interesse do governo como outras de interesse próprio foi o próprio Banco do Brasil (GOUVEA, 1994, p. 120). ${ }^{40}$ Esse mecanismo não parecia ser desconhecido pelos Ministros da Fazenda no período entre 1964 e $1985 .^{41}$ Sua relevância para a política econômica praticada no período foi relatada por Gouvea:

Em resumo, de conta provisória, a Conta Movimento havia se transformado em um dos principais instrumentos das políticas governamentais do período, passando a ser seu reflexo. Estas políticas se baseavam principalmente na captação de recursos com custos elevados e sua aplicação em programas subsidiados. Desta maneira a Conta passou a financiar ou com emissão de moeda ou com o acionamento da dívida pública, pesadas despesas como por exemplo a compra do trigo e os estoques reguladores, dentre outros, o que feria frontalmente o Artigo 62 da Constituição Federal que definia: "O orçamento anual (aprovado pelo Congresso) compreendia obrigatoriamente as despesas e receitas relativas a todos os órgãos e fundos, tanto da administração direta quanto da indireta". E a Conta

\footnotetext{
${ }^{40}$ A segunda seção da Lei 4.595/1964 é toda sobre o Banco do Brasil (artigos 19 a 21) e demonstra como o banco público teve poder para impedir a transferência de toda a autoridade monetária para o Banco Central. É possível interpretar que a gestão da Conta Movimento foi somente mais uma das consequências desse arranjo no qual o Banco do Brasil retinha substantivos poderes no contexto de criação do Banco Central. É curioso notar como, até hoje, os artigos da lei não foram explicitamente revogados por lei posterior. Uma pesquisa no sítio eletrônico do Planalto, que reúne todas as leis e atos normativos do país, demonstra que os três artigos sobre o Banco do Brasil continuam sem revogação explícita. Hoje, é impossível sustentar a vigência de alguns deles. As competências que em tese o Banco do Brasil detém estão descritas no artigo 19 da Lei. Em termos monetários, competiria a ele "financiar as atividades industriais e rurais" e "difundir e orientar o crédito", no financiamento das atividades econômicas e das exportações e importações. Mais importante, ele arrecadaria os depósitos voluntários à vista das instituições financeiras e executaria os serviços de compensação de cheques e outros papéis. Em termos fiscais, as duas principais competências do Banco do Brasil determinariam que ele fosse o agente financeiro do Tesouro Nacional, competindo a ele o recebimento, "a crédito do Tesouro Nacional, das importâncias provenientes de arrecadação de tributos ou rendas federais" e os pagamentos "necessários à execução do Orçamento Geral da União e leis complementares, de acordo com as autorizações que lhe forem transmitidas pelo Ministério da Fazenda". Além de receber e pagar todas as receitas e despesas do Tesouro Nacional, o Banco do Brasil também teria competência para "ser agente pagador e recebedor fora do país".

41 A partir de entrevista com Casimiro Antonio Ribeiro - funcionário do Banco do Brasil que foi recrutado por Octavio Gouvêa Bulhões para a criação da Superintendência da Moeda e do Crédito e que posteriormente se tornou diretor e funcionário do Banco Central -, de notícias de jornal e de depoimentos de técnicos do departamento de Administração Financeira do Banco Central, Gouvea (1994) busca demonstrar que os Ministros e a área econômica do governo tinham plenos conhecimentos a respeito da relevância que a Conta Movimento estava obtendo ao longo do período.
} 
Movimento não chegava até o Congresso e nem tinha qualquer outro tipo de divulgação ou controle. (GOUVEA, 1994, pp. 122-123)

A Conta Movimento, portanto, era uma das principais formas de gestão da política fiscal, mas o seu funcionamento não estava previsto de forma transparente em nenhum ato normativo e a prática não ensejava nenhum tipo de prestação de contas. A conta, inclusive, era utilizada para financiar atividades que muitas vezes eram financiadas também pelo Orçamento Monetário.

Embora a descrição do funcionamento e da organização das finanças públicas no país na década de 1980 possa não parecer tão complexa, o diagnóstico do que ocorria no país não era claro ou consensual à época. Ao longo da primeira metade da década de 1980, por exemplo, o Orçamento Fiscal indicava a geração de sucessivos superávits por parte do governo federal, uma vez que ele concentrava a receita de todos os recursos tributários, mas não as despesas, em particular os subsídios, os programas de fomento e crédito e até mesmo o serviço da dívida interna, que ficavam dispersos entre a Conta Movimento e o Orçamento Monetário (GUARDIA, 1992, p. 15). O complexo processo de fechamento da Conta Movimento e o conjunto mais amplo de medidas de reorganização das finanças públicas adotadas na segunda metade da década de 1980 demonstrarão a ausência de consenso sobre o tema.

\subsubsection{Do diagnóstico à reforma: o Executivo na reforma das finanças públicas}

A partir de 1980, em um contexto de crise econômica e de um acordo com o Fundo Monetário Internacional, celebrado em 1982, o Ministério da Fazenda começou a tomar medidas que permitiriam a constituição de um diagnóstico de crise nas finanças públicas e que futuramente subsidiariam a sua reforma (GUARDIA, 1992; GOUVEA, 1994, p. 152; Nóbrega e Loyola, in SOLA e WHITEHEAD, 2006). A primeira medida, ainda em 1981, foi a criação de um grupo informal de técnicos para discussão sobre a reorganização das finanças públicas, seguida da coleta de informações sobre dívida e endividamento público antes não produzidas (GOUVEA, 1994).

Ainda nesse contexto inicial, em 1983, o governo federal criou o Comitê Interministerial de Acompanhamento da Execução dos Orçamentos Públicos (COMOR), com o objetivo de "coordenar as funções de assessoramento aos Ministros 
da Fazenda e Chefe da Secretaria de Planejamento da Presidência da República em assuntos relacionados com a elaboração e execução dos orçamentos governamentais, tendo em vista os objetivos de controle monetário e de redução do déficit público". ${ }^{42} \mathrm{O}$ Comitê tinha competência para acompanhar a execução dos orçamentos e deveria se reunir semanalmente para se manifestar sobre qualquer proposta que pudesse afetar os objetivos de controle monetário e redução do déficit público (art. $6^{\circ}$ da Portaria de criação; GOUVEA, 1994, p. 160). Contudo, o diagnóstico sobre a situação das finanças públicas, que fomentaria a solução por meio de uma profunda reestruturação de competências, ainda não era compartilhado amplamente, dentro ou fora do governo.

Gouvea argumenta que foi a própria burocracia da área econômica do governo, com ajuda da comunidade acadêmica, que buscou estimular o argumento sobre a crise e a necessidade de reforma das finanças públicas (1994, p. 157). Um exemplo de argumento acadêmico a respeito da necessidade de reforma é a análise de um texto do professor de economia da Universidade de Campinas, José Carlos de Souza Braga. Escrito em 1982, o texto sustenta que, mesmo que se desejasse uma política de subsídios à indústria - e não uma política de ajuste fiscal -, o modelo das finanças públicas brasileiro das décadas de 1960 a 1980 não era o mais adequado. Para ele, a expansão da base monetária por meio de subsídios creditícios como os analisados na subseção anterior não geraria necessariamente pressão inflacionária caso esses subsídios "estivessem concorrendo para o aumento da produção interna e da exportável". Entretanto, em um contexto de recessão econômica e sem uma política industrial que direcionasse os subsídios concedidos para os setores produtivos, a expansão do crédito simplesmente implicava "a criação de fundos líquidos para especulação", sem potencial produtivo (BRAGA, 1982, pp. 209-210).

Ou seja, a prática fiscal, sem nenhum tipo de prestação de contas ou controle, possibilitava a implementação de uma política de endividamento público que não contribuía para o desenvolvimento econômico do país. É por isso que o texto concluía que deveria ocorrer "a integração dos orçamentos fiscal, monetário e das empresas estatais num orçamento público global que expressasse políticas de curto e longo prazos

\footnotetext{
42 Criado pela Portaria Interministerial do Ministério da Fazenda e da Secretaria de Planejamento da Presidência da República no 200, de 29 de julho de 1983, publicada no Diário Oficial da União de 2 de agosto de 1983, nas páginas 13668 - 13670.
} 
com vistas ao desenvolvimento" (1982, p.212). ${ }^{43}$ A mensagem do autor era clara: o diagnóstico de uma confusão entre autoridade monetária e autoridade fiscal, com a possibilidade de que houvesse dispêndios públicos sem a devida "retaguarda fiscal" exigia reforma das finanças públicas. O diagnóstico de Braga sobre a necessidade de unificação orçamentária se torna ainda mais relevante caso se considere que ele era compartilhado mesmo por economistas que não desejavam políticas industriais.

Por parte da burocracia, o grupo informal criado em 1981 recomendou diversas medidas às autoridades do Conselho Monetário Nacional, que, em 21 de agosto de 1984, decidiram designar formalmente a uma Comissão a apresentação de uma "moldura operacional e jurídica de um novo desenho institucional das finanças públicas" (GOUVEA, 1994, p. 158). ${ }^{44}$ A Comissão concluiu seus trabalhos no final de 1984. ${ }^{45}$ Dois ciclos de reforma das finanças públicas se seguiriam à conclusão destes trabalhos: um liderado pelo Executivo federal, entre 1985 e 1987; outro liderado pelo Legislativo e pela Constituinte, entre 1987 e 1989 (GUARDIA, 1992).

Quando da criação da Comissão, o Conselho Monetário Nacional apresentou quatro recomendações: (i) o objetivo central era o de que a Comissão apresentasse propostas que incorporassem no orçamento da União todas as despesas do governo federal, levando em consideração os poderes fiscais exercidos pelo Banco Central e pelo Banco do Brasil; (ii) a Comissão deveria propor medidas que eliminassem qualquer competência relacionada a atividades de fomento do Banco Central; (iii) e medidas que transferissem para o Ministério da Fazenda toda competência relativa à gestão da dívida pública, restando ao Banco Central somente a competência de operacionalização da dívida; (iv) por fim, a Comissão deveria propor a redefinição do papel do Banco do Brasil, preservando sua função de principal instrumento da política creditícia (BRASIL, 1984; GOUVEA, 1994, pp. 171-172). Nota-se que em nenhuma dessas propostas há uma discussão específica sobre ajuste fiscal ou regras que promoveriam esse ajuste.

\footnotetext{
43 Ou ainda: "É pertinente orientar os investimentos públicos (e os subsídios) segundo um plano governamental de articulação industrial público/privado, como também prover uma adequada retaguarda fiscal para fazer face aos dispêndios da administração". (BRAGA, 1982, pp. 212-213).

44 A Comissão foi criada pelo voto $\mathrm{n}^{\circ}$ 283, de 1984, do Conselho Monetário Nacional. A pesquisa conseguiu ter acesso ao voto por meio da cópia dos autos do processo da ação popular movida por Élquisson Soares, mencionada na introdução, a fls. 18 e discutida abaixo. Ver também o Parecer do Secretário-Geral Adjunto do Ministério da Fazenda, Raymundo Monteiro Moreira, de 22 de janeiro de 1985, e publicado no Diário Oficial da União do dia 20 de fevereiro de 1985, fls. 2820-2826, que menciona o voto de criação dessa Comissão.

${ }^{45}$ O relatório da Comissão Especial está disponível em Nóbrega (2005) e nos autos do processo da ação popular movida por Élquisson Soares, mencionada na introdução e discutida abaixo.
} 
O relatório final da Comissão sugeriu a adoção e o respeito aos princípios da universalidade e unidade orçamentária, que já eram previstos na Constituição do período ditatorial, mas desrespeitados na prática (os princípios serão discutidos em detalhes mais abaixo). Para a Comissão, as seguintes reformas poderiam garantir a efetividade desses princípios: (i) extinção do orçamento monetário; (ii) abertura de conta única do Tesouro Nacional, para evitar que a política fiscal fosse gerida a partir de diferentes contas; (iii) proibição de que o Banco Central atuasse na arrecadação de recursos ou na emissão de moeda para cobrir dificuldades financeiras da União; (iv) concentração das atividades do Conselho Monetário Nacional com o fim de integrar as políticas macroeconômicas, quais sejam, as políticas fiscal, monetária e cambial; além de exercer um maior controle na atividade de crédito que orientasse $\mathrm{o}$ desenvolvimento do mercado financeiro e do mercado de capitais. O relatório final apresentou ainda propostas específicas para o Tesouro Nacional, para o Banco Central e para o Banco do Brasil, além de diferenciar medidas de curto e de médio prazo a serem adotadas (GOUVEA, pp. 173 - 179).

A primeira medida relevante por parte do Executivo federal foi adotada ainda em 1984, no dia 13 de dezembro, quando o Conselho Monetário Nacional aprovou diversas medidas que apresentavam a programação monetária para o ano seguinte e que, na prática, "congelariam" a Conta Movimento e impediriam o Banco do Brasil de influenciar formalmente a base monetária do ano seguinte. Nesse sentido, sua atuação passaria a se aproximar daquela de qualquer banco comercial: em situações de emergência, deveria proceder a empréstimos formais junto ao Banco Central, e não dos créditos junto à Conta Movimento (GOUVEA, pp. 173-179).

Uma semana depois da decisão do CMN, Élquisson Soares, à época Deputado Federal pelo PMDB, promoveu ação popular perante a Justiça Federal de Brasília contra qualquer medida que a efetivasse. O deputado alegou que as medidas seriam ilegais, pois desestabilizariam o Banco do Brasil e provocariam dano ao erário (Nóbrega e Loyola in SOLA e WHITEHEAD, 2006; GOUVEA, 1994, p. 185). ${ }^{46}$ De acordo com a narrativa da inicial, “as 'medidas administrativas' aprovadas na reunião do Conselho Monetário Nacional do dia 13.12.1984 [...] se postas em prática, ilegal e absurdamente, sob a condenação unânime da Nação brasileira, simplesmente desestabilizarão o

\footnotetext{
46 Trata-se da ação popular que ganhou o número original 230-AD184. Posteriormente, o processo foi renumerado para o $\mathrm{n}^{\circ}$ 84.00.20753-0. O atual número do processo é: 0001274-78.1984.4.01.3400. O processo foi distribuído para a $5^{\mathrm{a}}$ Vara da Justiça Federal de Brasília.
} 
BANCO DO BRASIL S/A, a maior, mais eficiente e mais respeitada instituição financeira do País, reduzindo-o a posição de reles banco comercial comum" (fls. 2-3). Na petição inicial da ação popular, o deputado defendia o "sistema de dualidade de autoridades monetárias", no qual o Banco do Brasil ocuparia função central, e argumentava ainda que a reforma era ilegal, essencialmente, porque fazia o banco perder a condição de autoridade monetária. Ao fim, a ação pediu a suspensão liminar das medidas adotadas pelo Conselho.

Acatando os argumentos do deputado, a Justiça Federal determinou a suspensão das medidas questionadas no mesmo dia da propositura da ação. A decisão da juíza Federal Ana Maria Pimentel Tristão, da 5a Vara da Justiça Federal de Brasília, de 19 de dezembro de 1984, determinou:

Concedo a liminar requerida para determinar que as autoridades apontadas rés se abstenham de praticar atos de execução que viabilizem as medidas adotadas na reunião do Conselho Monetário Nacional, de 13 de dezembro de 1984, que passam a atingir a estrutura, a competência do Banco do Brasil S.A., ou de qualquer forma causem lesão ao patrimônio público (fls. 172). ${ }^{47}$

Essa é a íntegra da decisão, escrita à mão pela juíza federal. A determinação da suspensão da decisão do CMN, aliada à ausência de mobilização das elites políticas para promover uma reforma institucional das finanças públicas no ano de 1984 e no início de $1985^{48}$, fez com que as demais medidas propostas pela Comissão fossem provisoriamente deixadas de lado pelo governo federal (GOUVEA, 1994, p. 185).

\footnotetext{
${ }^{47}$ A decisão, escrita em letra corrida nos autos do processo, foi transcrita pelo Jornal Estado de São Paulo, no dia 21 de dezembro de 1984, na página 24.

${ }^{48}$ Gouvea relata em detalhes como a relação entre o então Ministro da Fazenda, Francisco Dornelles, e o então Ministro do Planejamento, João Sayad, não facilitaram a implantação das reformas no início da Nova República. Segundo Gouvea, Dornelles entendia que o principal problema brasileiro derivava do tamanho do gasto público. Para ele, somente o corte de gastos poderia promover o controle inflacionário. Sayad, por sua vez, entendia que o problema não era o tamanho dos gastos públicos, mas sim o seu controle. Essa conjuntura, aliada à realização de eleições para deputado federal e senador em 1986, além da morte de Tancredo Neves, seria exemplo da falta de força de vontade política em avançar com a reforma proposta. A situação só começaria a melhorar com a saída de Dornelles do Ministério da Fazenda e a entrada de Dilson Funaro, mais próximo das ideias de Sayad (GOUVEA, 1994, pp. 188-193). Logo após a decisão da juíza da $5^{\text {a }}$ Vara da Justiça Federal de Brasília, reportagem do jornal o Estado de São Paulo de 21 de dezembro de 1984 denunciava que: "alta fonte do governo revelou que ontem, durante a reunião matutina no Palácio do Planalto, o Presidente Figueiredo [que deixaria o governo em poucos dias] manifestou seu descontentamento com a aprovação da reforma e requereu do Ministro Delfim Netto explicações sobre a questão. Delfim disse ao presidente que não estava inteirado do assunto.”. Ou seja, realmente não parecia haver consenso entre as elites políticas sobre qual rumo a reforma deveria tomar.
} 
As medidas só seriam paulatinamente retomadas a partir da segunda metade de 1985. A primeira medida relevante foi o envio do Projeto de Lei do Orçamento de 1986 com a incorporação das responsabilidades do Tesouro Nacional relativas a despesas não reembolsáveis, antes excluídas da peça orçamentária (GUARDIA, 1992, pp. 20 e 32). ${ }^{49}$

A segunda medida relevante foi a aprovação, em 30 de janeiro de 1986, a partir da influência do Ministro da Fazenda, Dilson Funaro, das mesmas medidas do Conselho Monetário Nacional que "congelavam" a Conta Movimento entre o Banco do Brasil e o Banco Central. A nova suspensão da medida pela Justiça Federal, em 28 de fevereiro de 1986, nos autos do mesmo processo da ação movida pelo Deputado Élquisson Soares, foi revertida em sede de recurso, o que garantiu a efetividade da medida (GOUVEA, 1994, p. 186; Nóbrega e Loyola in SOLA e WHITEHEAD, 2006). ${ }^{50}$

Na sequência, o Presidente da República, José Sarney, criou a Secretaria do Tesouro Nacional na estrutura burocrática do Ministério da Fazenda, como um dos órgãos centrais de planejamento, coordenação e controle financeiro do governo federal. A Secretaria do Tesouro Nacional foi criada com competência para controlar as operações realizadas por conta e ordem do Tesouro Nacional e outras decorrentes de empréstimos e financiamentos do Tesouro. ${ }^{51}$ A unificação dos recursos do Tesouro Nacional em Conta Única, prevista no Decreto-Lei $\mathrm{n}^{\circ} 200$, desde 25 de fevereiro de 1967, foi efetivamente realizada apenas a partir das regras criadas pelo Decreto n ${ }^{\circ}$ 93.872, de 23 de dezembro de 1986, e da promulgação da Constituição, em 1988.

A Secretaria do Tesouro Nacional somente passaria a ter competência explícita para administrar e controlar a dívida mobiliária federal em $1987 .{ }^{52}$ No mesmo ano, o Executivo proibiria a emissão líquida de títulos da dívida mobiliária sem autorização legislativa, e promoveria o ajuste entre Orçamento Monetário e o Orçamento Fiscal com a passagem das despesas do primeiro ao segundo e com previsões sobre os resultados anuais do Banco Central ao Tesouro, além da remuneração das disponibilidades do Tesouro Nacional na Conta Única. ${ }^{53}$

\footnotetext{
${ }^{49} \mathrm{O}$ que inclusive fez com que o Orçamento apresentasse previsão de déficit, em quantidade similar ao montante das despesas que lhe foram transferidas (GUARDIA, 1992, pp. 20 e 32).

${ }^{50} \mathrm{Em}$ 1986, a União apresentou agravo de instrumento e um mandado de segurança contra a nova decisão liminar de 1986, que acabaram revertendo a decisão de $1^{\mathrm{a}}$ instância.

${ }^{51}$ Decreto $\mathrm{n}^{\circ}$ 92.452, de 10 de março de 1986.

52 Decreto $\mathrm{n}^{\mathrm{o}}$ 94.443, de 12 de junho de 1987, concedendo a competência ao MF e Portaria no 430 de 22 de dezembro de 1987, delegando-a.

${ }^{53}$ Decreto-Lei no 2.376, de 25 de novembro. Sobre todas as medidas, ver também Guardia (1992, pp. 20 22). Guardia discute em detalhes a criação do Orçamento das Operações de Crédito, administrado pela STN e que passou a integrar o Orçamento Geral da União a partir do ano de 1988.
} 
Ainda no ano de 1987, o governo federal implantaria um novo sistema de execução financeira do Orçamento, usado até hoje, chamado de Sistema Integrado de Administração Financeira do Governo Federal (SIAFI). O SIAFI permitiu que a administração dos recursos do Tesouro, a partir da Conta Única, contasse com um sistema seguro e capaz de fornecer informações gerenciais em tempo real para os gestores. Desenvolvido em parceria com o Serviço Federal de Processamento de Dados, o SIAFI se consolidou como um instrumento ao mesmo tempo de controle, transparência e gestão dos recursos públicos federais. Talvez a maior vantagem do SIAFI tenha sido a de que ele permitiu que todos os órgãos da Administração Direta e grande parte dos órgãos da Administração Indireta pudessem fazer uso automático dos recursos da União, sem que a Secretaria do Tesouro deixasse de ter a informação em tempo real do uso desse recurso público. ${ }^{54}$ Nesse contexto, além de facilitar o controle da execução orçamentária pelo governo federal, o SIAFI também facilitou o controle do dispêndio de recursos públicos por cidadãos e pelo Congresso Nacional (TAVARES, 2005, p.6).

No entanto, nem a criação da Secretaria do Tesouro Nacional nem a do SIAFI significaram a conclusão da reorganização orçamentária e a unificação dos orçamentos existentes no país. Novas medidas ainda teriam que ser colocadas em prática pelo Executivo na tentativa de definitivamente separar as funções fiscais relativas ao Tesouro Nacional das monetárias relativas ao Banco Central. Nos meses seguintes à criação da Secretaria, o Executivo ainda proibiria o Banco Central de emitir títulos para fins de política monetária, com a transferência ao Ministério da Fazenda da maior parte dos fundos de fomento que continuavam a ser geridos pelo Banco Central e incluiria, na peça orçamentária, outras operações antes excluídas (GUARDIA, 1992). ${ }^{55}$

\subsubsection{A Constituinte e o Legislativo na reforma}

A reforma realizada em âmbito Executivo seria complementada pela reforma do regime jurídico da política fiscal no plano Legislativo nos anos subsequentes, em

\footnotetext{
${ }^{54}$ O SIAFI é provavelmente um dos casos de pequenas inovações institucionais de maior sucesso da administração pública federal. Para além do site oficial, disponível em <http://www.tesouro.fazenda.gov.br/siafi> (último acesso em 6 de outubro de 2014), ver Da Silva, Palmeira e Quintana (2007) que apontam a necessidade de reformular o SIAFI. A criação do Novo Siafi, em fase de testes desde janeiro de 2012, pretende adaptar a plataforma original do sistema para uma plataforma mais amigável e simplificada.

${ }^{55}$ Como as de dívida financeira de Estados e Municípios, de Bancos Estaduais, o refinanciamento da dívida externa com o aval do Tesouro, financiamento de investimentos agrícolas, entre outros.
} 
especial com a aprovação da Constituição. A Constituição de 1988 reafirmou e legitimou os princípios da universalidade e unidade orçamentárias, além de ter reorientado as relações entre Executivo e Legislativo nas deliberações sobre orçamento. A Constituição ainda reforçou a ideia do planejamento nas decisões orçamentárias, com a previsão de novos diplomas orçamentários, como o Plano Plurianual (PPA) e a Lei de Diretrizes Orçamentárias (LDO). ${ }^{56}$

No âmbito do planejamento ${ }^{57}$, o PPA foi previsto para estabelecer, de forma regionalizada, diretrizes, objetivos e metas da Administração Pública direta e indireta. Sua criação não foi uma novidade significativa, considerando que o sistema constitucional anterior previa a elaboração de um Orçamento Plurianual de Investimentos (OPI), trienal, que possuía funções semelhantes (GUARDIA, 1992). De qualquer modo, o PPA foi concebido para funcionar como um verdadeiro plano de ação para o governo federal, devendo ser elaborado ao longo do primeiro ano de mandato de cada governo para ter validade do segundo ano do mandato até o primeiro ano do mandato do governo subsequente.

Ainda no sistema de planejamento, a Constituição Federal previu a criação da LDO, que faria a conexão entre o PPA e a Lei Orçamentária Anual (LOA). A LDO foi a inovação mais sensível no sistema constitucional de planejamento, pois se considerava que ela atacava uma das maiores fragilidades do sistema de planejamento anterior: a falta de comunicação entre OPI e LOA (GUARDIA, 1992, p. 67). A LDO foi criada para dispor sobre as metas e as prioridades da administração pública federal, incluindo as despesas de capital para o exercício financeiro subsequente, além de orientar a elaboração da lei orçamentária anual, dispor sobre as alterações na legislação tributária e estabelecer a política de aplicação das agências financeiras oficiais de fomento $\left(\S 2^{\circ}\right.$, art. $165, \mathrm{CF})$.

A ideia básica que permeou a criação da LDO foi a de estabelecer pontos mínimos de consenso entre Legislativo e Executivo para facilitar a discussão sobre o orçamento a ser realizada na sequência. ${ }^{58}$ Nos termos das discussões abordadas no

\footnotetext{
${ }^{56}$ É evidente que a Constituição trouxe mudanças significativas também quanto ao tema tributário, no regime jurídico da política físcal em seu sentido mais amplo. Contudo, este trabalho não discutirá as mudanças na ordem tributária por entender que elas estão fora do escopo de análise.

57 Além de PPA e LDO, o sistema constitucional de planejamento ainda prevê a criação de planos diretores para os municípios, planos de educação e de reforma agrária, além de planos nacionais e regionais de ordenação territorial e de desenvolvimento econômico e social, e planos e programas nacionais, regionais e setoriais de desenvolvimento.

${ }^{58}$ Ver, por exemplo, Guardia: "A LDO assume um papel crucial no atual sistema de planejamento, podendo contribuir para a "diluição" das demandas ao longo das diversas etapas do processo de
} 
capítulo 1, a LDO é elemento significativo do procedimento de votação de matérias orçamentárias porque, ao permitir o estabelecimento de pontos mínimos de consenso em termos de metas entre Legislativo e Executivo, busca evitar tanto uma situação de não decisão quanto a ocorrência do problema do fundo comum.

A LDO se tornou uma peça-chave na gestão da política fiscal no país principalmente após o ano de 1998, quando a Medida Provisória ${ }^{\circ} 1.716$, de 8 de setembro de 1998, alterou a LDO de $1999^{59}$ para prever uma meta explícita de superávit primário para o setor público consolidado no ano seguinte. O procedimento de a LDO prever uma meta explícita de superávit foi posteriormente incorporado ao sistema orçamentário pela Lei de Responsabilidade Fiscal. Daquele ano em diante, até hoje, todas as metas fiscais do governo passariam a constar da LDO. Essa discussão será retomada na próxima seção deste capítulo.

Por fim, a Constituição previu diversas regras e princípios da LOA. Em primeiro lugar, buscando dar concretude aos princípios da universalidade e unidade, a Constituição determinou que a LOA passasse a compreender três diferentes documentos: o Orçamento Fiscal, o Orçamento da Seguridade Social e o Orçamento de Investimento das Empresas Estatais. A inclusão do Orçamento de Investimento das Empresas como parte do Orçamento Anual foi um dos principais avanços para o respeito dos referidos princípios que determinam que a peça orçamentária deva ser única, contendo todas as receitas e despesas do Estado. No âmbito de efetivação desses princípios, a Constituição ainda previu regra que determina que qualquer isenção, anistia, remissão, subsídio e benefício de natureza financeira, tributária e creditícia devem acompanhar o projeto de Lei Orçamentária com previsão regionalizada de seu impacto. Caso se leve em consideração o contexto constitucional anterior, no qual essas atividades não constavam da legislação orçamentária e não eram apreciadas nas discussões orçamentárias, essa regra constitucional representa uma garantia aos princípios da universalidade e unidade (GUARDIA, 1992, p. 80).

A simples regra constitucional de divisão do Orçamento em três peças também serve para exemplificar como o direito pode servir para estruturar debates relativos a

planejamento e orçamentação. Vale dizer, caso a LDO permita a clara especificação das prioridades para o exercício financeiro subseqüente, em conformidade com os objetivos gerais estabelecidos no PPA, estar-se-ia contribuindo para reduzir a possibilidade de pressões na etapa de elaboração do orçamento. Contudo, a LDO parece ainda não ter encontrado seu "espaço" no novo processo orçamentário brasileiro, ficando sua utilização muito aquém dos objetivos traçados pelos deputados constituintes" (GUARDIA, 1992, p. 68).

${ }^{59}$ Lei $^{\circ}$ 9.692, de 27 de julho de 1998. 
políticas macroeconômicas. Ao escolher criar um orçamento da Seguridade Social, que compreende todas as entidades e órgãos a ela vinculados, da administração direta e indireta, bem como fundos e fundações instituídos e mantidos pelo Poder Público, uma regra constitucional sobre a organização do orçamento dá destaque às receitas e despesas dessa natureza em relação às demais receitas e despesas que compõem o Orçamento Fiscal (basicamente, todos os gastos e receitas que não se enquadram na rubrica de Seguridade Social e Investimento das Empresas Estatais, como gastos com remuneração da dívida - que a partir de 1998 passaram a ser identificados especificamente, a partir da determinação da Lei de Diretrizes Orçamentárias para 1998 -, educação, segurança, defesa etc.). Em outras palavras, facilitam-se a identificação e a discussão de temas relacionados à Seguridade Social em relação a outros temas orçamentários.

Em termos macroeconômicos, a Constituição ainda previu uma importante limitação orçamentária, conhecida como "regra de ouro" das finanças públicas: a Constituição passou a vedar a realização de operações de crédito que excedessem o montante das despesas de capital previstas na LOA (art. 167, III). Em outras palavras, a regra prevê que o déficit público financiado por meio de empréstimos (operações de crédito) não pode ultrapassar o nível de investimentos do país e de abatimento de dívida (montante das despesas de capital). Essa é uma significativa limitação jurídica das opções fiscais, pois faz com que eventuais previsões de déficit público só possam equivaler aos investimentos que serão realizados ou operações que reduzam o total da dívida.

Por fim, a Constituição delimitou regras para a intervenção do Legislativo no processo orçamentário. Comparando-as ao sistema constitucional anterior, houve uma ampliação da possibilidade de participação do Legislativo (GUARDIA, 1992, p. 87 92). Ainda assim, elas concentram os poderes fiscais consideravelmente no Executivo.

As regras constitucionais dispõem que cabe a uma comissão mista de Deputados e Senadores (hoje conhecida como Comissão Mista de Orçamento) o exame e a emissão de parecer sobre os projetos de lei relativos ao PPA, à LDO, à LOA e aos créditos adicionais, todos de competência privativa do Executivo. Os plenos da Câmara e do Senado, de acordo com o regimento das casas, também devem apreciar esses projetos de lei, após a emissão do parecer pela Comissão.

Talvez a previsão mais relevante sobre o procedimento de votação do Orçamento seja a de que as emendas parlamentares ao projeto de lei orçamentária anual 
somente poderão ser apresentadas na Comissão Mista e que essas emendas devem: (i) ser compatíveis com PPA e LDO; (ii) indicar os recursos necessários, admitidos apenas os provenientes de anulação de despesa que não incidam em dotações para pessoal e encargos, serviço da dívida e transferências tributárias constitucionais para Estados, Municípios e Distrito Federal. ${ }^{60}$

Esse procedimento de aprovação das leis orçamentárias - e da LOA em particular - dá grande ênfase ao Poder Executivo nas deliberações orçamentárias em relação ao Poder Legislativo por dois motivos.

Em primeiro lugar, pela extensão e complexidade técnica das peças orçamentárias, o Poder Executivo, que detém a prerrogativa legal de propor os projetos, já tem uma importante diferença em relação ao Poder Legislativo: ele estabelece e determina a agenda de debates em relação às peças orçamentárias. Em outras palavras, o Executivo tem a prerrogativa de propor a primeira versão das leis orçamentárias, estabelecendo os pontos de partida para qualquer deliberação.

É bem verdade que grande parte das despesas orçamentárias são vinculadas, ou seja, expressiva parte do orçamento é automaticamente direcionada para despesas determinadas constitucional ou legalmente, como são os casos de gastos com pessoal, seguridade social e com a dívida pública. ${ }^{61}$ Ainda assim, para os gastos discricionários que restam, o Executivo retém uma relevante prerrogativa, uma vez que ele faz a proposta inicial de como os recursos serão gastos. Nesse sentido, o dispositivo constitucional que determina que as emendas parlamentares ao projeto de lei orçamentária anual devam ser compatíveis com o PPA e com a LDO reforça a importância do Legislativo ter que debater e discutir as metas e as diretrizes da Administração nas fases de planejamento, sob pena de ver sua influência nas decisões orçamentárias futuras ser reduzida (GUARDIA, 1992, p. 80). Em especial em um contexto de ajuste fiscal, no qual os recursos se tornam ainda mais escassos.

\footnotetext{
${ }^{60}$ As emendas também podem ser relacionadas com a correção de erros ou omissões ou com dispositivos do texto do projeto de lei.

${ }^{61}$ Somente no ano de 2013, por exemplo, no âmbito do Poder Executivo, as despesas discricionárias constantes do orçamento corresponderam ao total de $\mathrm{R} \$ 253.896 .381 .706,00$. Em comparação ao orçamento, estimado para aquele ano em R $\$ 2.276 .516 .541 .532,00$, aquele valor corresponde a $11,15 \%$ do Orçamento. Ou seja, de tudo o que se arrecada, por meio de tributos e emissão de títulos da dívida, o governo federal só possui discricionariedade para gastar cerca de $11 \%$ do orçamento. O resto é composto por despesas obrigatórias, aquelas cujo pagamento está previsto na Constituição ou em outra legislação infraconstitucional. Destacam-se entre as despesas obrigatórias: pagamento do serviço da dívida; pessoal e encargos, benefícios da previdência social e transferências constitucionais a Estados e Municípios. Os dados estão disponíveis em: <http://www.orcamentofederal.gov.br/informacoes-orcamentarias> (último acesso em 8 de outubro de 2014).
} 
Em segundo lugar, a restrita possibilidade de apresentação de emendas parlamentares ao projeto de lei orçamentária anual, que só pode ocorrer no caso de anulação de despesas e com indicação de recursos, é outro elemento que concentra poderes no Executivo. Embora ele garanta alguma possibilidade de participação do Legislativo no procedimento de aprovação da peça orçamentária, esse procedimento tende a reduzir consideravelmente a possibilidade de que o Legislativo transforme significativamente a peça orçamentária, uma vez que, como sua atuação só pode ocorrer por anulação de despesas previstas, ele fica proibido de criar despesas novas. ${ }^{62}$

A Constituição ainda dispôs sobre papéis exclusivos do Senado nas seguintes atividades relativas à política fiscal, praticamente repetindo a Constituição anterior: (i) autorização de operações financeiras para a União, Estados e Municípios e as empresas estatais (art. 52, V); (ii) fixação, por proposta do Presidente da República, de limites globais para o montante da dívida consolidada (art. 52, VI); (iii) estabelecimento de limites globais e condições para as operações de crédito externo e interno da União, Estados, Distrito Federal, e dos Municípios, além de autarquias e demais entidades controladas pelo Poder Público Federal (art. 52, VII); (iv) estabelecimento de limites globais e condições também para o montante da dívida mobiliária dos Estados, do Distrito Federal e dos Municípios (art. 52, IX).

A mera apresentação da lista de competências privativas do Senado Federal já aponta para a relevância de um âmbito da reforma do regime jurídico da política fiscal que não parece ter sido enfatizado na organização dos esforços de reforma da década de 1980 realizada até aqui: a relação federativa. Como se demonstrará, esse tema se tornou central na reforma do regime jurídico na década de 1990.

As medidas adotadas na década de 1980 criaram uma crise das condições de financiamento dos Estados, com redução dos empréstimos federais, dificuldade de captação de crédito no cenário internacional e redução das receitas ordinárias, tanto pela redução das transferências federais como pela crise das empresas estatais controladas. Esse contexto motivou os governadores a usarem os próprios bancos públicos estaduais para financiar suas atividades. As tentativas de controle do endividamento público

\footnotetext{
${ }^{62}$ Para uma discussão sobre o tema e um estudo do período entre 1996 e 2001, ver Figueiredo e Limongi (2008). Os autores argumentam: "Tendo em vista as múltiplas restrições vigentes, sobretudo as regras que regulam o processo orçamentário, o grau de intervenção do Congresso na definição dos gastos públicos é limitado, previsível e, ademais, organizado de forma a preservar as prioridades definidas pelo Executivo, ao mesmo tempo em que limita a influência dos interesses individuais dos parlamentares." (FIGUEIREDO e LIMONGI, 2008, p. 29). Os autores enfatizam que as regras de participação dos parlamentares se tornaram ainda mais restritivas após mudanças no regime interno da Comissão Mista de Orçamento.
} 
estadual - em especial com a Resolução do Senado Federal no 87, de 30 de junho de 1987, com o Regime de Administração Especial Temporária (criado pelo Decreto-Lei $\mathrm{n}^{\mathrm{o}} 2.321$, de 25 de fevereiro de 1987), com a Lei $\mathrm{n}^{\mathrm{o}} 7.614$, de 14 de julho de 1987, e com a primeira lei de refinanciamento das dívidas estaduais (Lei $n^{\circ} 7.976 / 1989$ ) - não surtiram os efeitos desejados, o que fez com que as dificuldades fiscais regionais e municipais continuassem nos anos 1990 (LOPREATO, 2002, p. 161; LEITE, 2005, p. $50)$.

Por fim, outras duas regras constitucionais relevantes estabeleceram que leis complementares futuras deveriam dispor sobre limites de despesa com pessoal e sobre as finanças públicas em geral. A primeira lei complementar que tratou de limites de pessoal, proposta pela então deputada Rita Camata, do PSDB, em 1989, daria origem à chamada Lei Camata, em 1995. A lei complementar sobre finanças públicas só viria a entrar em vigor quando da aprovação da Lei de Responsabilidade Fiscal, em 2000.

\subsubsection{Um resumo da reforma das finanças públicas da década de 1980}

As medidas descritas no item (ii) e (iii) acima e sumariadas na tabela abaixo constituem o marco inicial da reconstrução do atual regime jurídico da política fiscal para esta pesquisa, porque elas promoveram a centralização formal da autoridade fiscal na Secretaria do Tesouro Nacional e no Ministério da Fazenda, o que persiste até hoje. Essas regras e princípios também previram mecanismos novos de controle do gasto e do endividamento público pelas autoridades e estabeleceram regras mínimas de participação nas deliberações orçamentárias para o Legislativo, que têm impacto direto sobre a política fiscal.

Em tese, a centralização da autoridade fiscal, acompanhada do respeito aos princípios da universalidade e da unidade orçamentárias, facilita o controle das contas públicas pelo Congresso Nacional e pela sociedade em geral em comparação ao período anterior, quando não havia uma única ou uma definitiva autoridade fiscal no país. Como se demonstrou, antes da reforma, nem mesmo o Ministério da Fazenda poderia ser considerado a autoridade fiscal definitiva, uma vez que o Banco do Brasil e o Banco Central podiam emitir moeda ou títulos da dívida sem qualquer tipo de comunicação com o órgão. O controle das finanças públicas era muito mais difícil, senão impossível, já que sequer o governo federal tinha clareza sobre quem detinha poder para promover o gasto e o endividamento público. 


\begin{tabular}{|c|c|c|c|c|c|}
\hline \multicolumn{6}{|c|}{ Regras e princípios jurídicos para a política fiscal na década de 1980} \\
\hline & \multicolumn{2}{|c|}{ Executivo } & & \multicolumn{2}{|c|}{ Legislativo e Constituinte } \\
\hline Ano & Resumo do ato & $\begin{array}{c}\text { Diploma } \\
\text { normativo }\end{array}$ & Ano & Resumo do Ato & $\begin{array}{r}\text { Diploma } \\
\text { normativo }\end{array}$ \\
\hline \multirow{2}{*}{1985} & $\begin{array}{l}\text { Congelamento da } \\
\text { Conta Movimento }\end{array}$ & $\begin{array}{l}\text { Resolução } \\
\text { CMN }\end{array}$ & \multirow{8}{*}{1988} & PPA & art. $165, \mathrm{I}$ \\
\hline & $\begin{array}{l}\text { PLOA de } 1986 \text { com } \\
\text { inclusão de despesas } \\
\text { reembolsáveis }\end{array}$ & PLOA 1986 & & LDO & art. 165, II \\
\hline \multirow{2}{*}{1986} & $\begin{array}{l}\text { Novo "congelamento" } \\
\text { da Conta Movimento }\end{array}$ & $\begin{array}{l}\text { Re e dição } \\
\text { resolução } \\
\text { CMN }\end{array}$ & & $\begin{array}{l}\text { LOA em } 3 \text { Orçamentos } \\
+ \text { princípios unidade e } \\
\text { universalidade }\end{array}$ & art. $165, \S 50$ \\
\hline & Cria ção da STN & $\begin{array}{l}\text { Decreto } \mathrm{n} \text { - } \\
92.452\end{array}$ & & $\begin{array}{l}\text { Impossibilidade de } \\
\text { renúncia fiscal sem } \\
\text { previsão } \\
\text { regionalizada do } \\
\text { impacto }\end{array}$ & art. $165, \S 60$ \\
\hline \multirow{4}{*}{1987} & $\begin{array}{l}\text { STN passa a } \\
\text { administrare } \\
\text { controlar a dívida } \\
\text { mobiliária federal }\end{array}$ & $\begin{array}{l}\text { Decreto } \mathrm{n} \text { - } \\
94.443\end{array}$ & & \begin{tabular}{|l} 
Vedação de \\
realização de \\
operações de crédito \\
que excedam o \\
montante das
\end{tabular} & art. 167, III \\
\hline & $\begin{array}{l}\text { Proibição da emissão } \\
\text { líquida de dívida } \\
\text { mobiliária sem } \\
\text { autorização } \\
\text { legislativa } \\
\end{array}$ & $\begin{array}{l}\text { Decreto-Lei } \\
\text { no } 2.376\end{array}$ & & $\begin{array}{l}\text { Procedimento da } \\
\text { deliberação } \\
\text { orçamentária }\end{array}$ & art. 166 \\
\hline & $\begin{array}{l}\text { Ajuste entre } \\
\text { Orçamentos } \\
\text { Monetário e Fiscal }\end{array}$ & $\begin{array}{l}\text { Decreto-Lei } \\
\text { no } 2.376\end{array}$ & & $\begin{array}{l}\text { Lei complementar } \\
\text { para limites de } \\
\text { despesas }\end{array}$ & art. 169 \\
\hline & Cria ção do SIAFI & & & $\begin{array}{l}\text { Lei complementar } \\
\text { para finanças } \\
\text { públicas }\end{array}$ & art. 165 , §9o \\
\hline
\end{tabular}

Tabela 1: Regras e princípios jurídicos para a política fiscal na década de 1980. Elaboração própria.

Uma análise das medidas resumidas na tabela demonstra que a reforma promovida na década de 1980, embora conectada a diversas opções políticas - como a 
discussão sobre a relação entre Executivo e Legislativo e o grau de participação do Legislativo nas deliberações orçamentárias - não está necessariamente relacionada a uma visão específica sobre a política fiscal, seja ela de cunho keynesiano ou de outra matriz. Em outras palavras, a reforma das finanças públicas nesse período não estava conectada a uma única visão econômica sobre a política fiscal.

Para além da hipótese já apresentada por Gouvea, de que faltava um diagnóstico consensual por parte da burocracia a respeito da necessidade de promover um ajuste fiscal como condição para a estabilização econômica, Leite (2006, pp. 50 e 55) acrescenta que não havia interesse da classe política e da sociedade em geral na promoção da agenda do ajuste na década de 1980; no caso específico da Constituinte, a autora acrescenta ainda a hipótese de que o constituinte redator da subcomissão de Orçamento e Fiscalização Financeira, José Serra, teria tido papel relevante no direcionamento da agenda de reforma deste momento. ${ }^{63}$

Quanto a este último ponto, a agenda do ajuste fiscal e da sustentabilidade da dívida pública realmente não parecia fazer parte dos trabalhos da Constituinte. Em pesquisa aos anais da Constituinte ${ }^{64}$, relativas às reuniões da subcomissão de Orçamento e Fiscalização Financeira, constatou-se que a expressão "ajuste fiscal" e a palavra "sustentabilidade" não foram usadas sequer uma vez nas reuniões; a palavra austeridade foi mencionada somente sete vezes, sendo cinco na palestra de Mário Henrique Simonsen, que não era Constituinte, uma na de Andrea Calabi, à época Secretário do Tesouro Nacional e que também não era Constituinte, e somente uma vez por um Deputado Constituinte, Messias Gois, o único que parecia estar conectado claramente à agenda do ajuste fiscal nos termos do capítulo 1. Messias Gois, junto a Nilson Holanda, outro constituinte, foi um dos poucos membros da subcomissão que claramente defendeu regras de equilíbrio entre despesas e receitas para a Constituição.

\footnotetext{
${ }^{63}$ Leite transcreve trechos de suas entrevistas com dois políticos da época para demonstrar a ausência desse interesse na classe política e na sociedade. Em entrevista com José Roberto Rodrigues Afonso, o entrevistado falou: "em 1988, se você falasse em déficit público, achavam que você era maluco. Não havia interesse! Não adiantava você apresentar (proposta de reforma fiscal)... não tinha eco na classe política, aquilo não era matéria que interessava." (LEITE, 2005, p. 55). A entrevista mais interessante é a com o ex-ministro Bresser-Pereira: "Segundo o ex-Ministro, a palavra de ordem no país em 1987 era: "quanto mais gasta, melhor, porque cria demanda agregada e permite que o Estado cumpra suas tarefas sociais". Não havia limitação fiscal real, que era vista como invenção de economistas ortodoxos "incompetentes e mal intencionados". Toda a classe política, inclusive os progressistas, era contra o ajuste fiscal." (ibidem, p. 51).

64 A pesquisa foi realizada com base nos anais da Constituinte disponibilizados pelo site do Senado Federal, por meio do sistema de busca disponibilizado no próprio programa Adobe.
} 
No caso específico de José Serra, nas suas dezesseis intervenções ao longo dos trabalhos como redator da Subcomissão de Orçamento e Fiscalização Financeira, ele: (i) defendeu a fiscalização orçamentária e a maior participação dos Tribunais de Conta e do Legislativo nas deliberações orçamentárias; (ii) sugeriu que a participação do Legislativo na elaboração do orçamento deveria estar em uma posição intermediária entre participação total e impossibilidade de participação; (iii) criticou a vinculação de percentuais orçamentários a determinadas funções e despesas; (iv) criticou os poderes fiscais do Banco Central e a possibilidade de um Banco Central independente, proposta por Mário Henrique Simonsen; (v) defendeu mecanismos para efetivar os princípios da unidade e universalidade orçamentária, em especial a elaboração de um orçamento dividido em três ou quatro partes, diferenciando-o em orçamento das estatais e orçamento fiscal, pelo menos.

Em síntese, a principal preocupação existente na década de 1980 era com a possibilidade de o governo central ter o controle do orçamento geral da União e da execução orçamentária, assim como permitir algum espaço do Legislativo nessas atividades. Tendo em vista esses objetivos, a reforma parece ter alcançado minimamente seus objetivos.

$\mathrm{Na}$ reforma do regime jurídico que sucedeu os trabalhos da Constituinte, contudo, os objetivos da reforma do regime jurídico da política fiscal seriam substancialmente modificados e passariam a estar claramente conectados com uma determinada concepção de política fiscal.

\subsection{Um novo regime jurídico da política fiscal e a agenda do ajuste fiscal e da sustentabilidade da dívida pública}

Declarações de várias autoridades federais servem como indício de que a partir de 1988 o governo federal organizou um regime jurídico para a política fiscal relacionado à agenda do ajuste fiscal e da sustentabilidade da dívida pública. Nos termos das teorias exploradas no capítulo 1, é possível afirmar que a reforma estava conectada às teorias críticas ao pensamento keynesiano, em especial aquelas que criticam o impacto de políticas fiscais contracíclicas na solvência e na sustentabilidade futura da dívida pública. Foi na década de 1990, e principalmente a partir de 1994, que várias leis começaram a ser aprovadas explicitamente com a ideia de favorecer o ajuste fiscal. 
Na justificação do projeto de Lei Complementar $n^{\circ}$ 60, de 1989, que deu origem à Lei Complementar $\mathrm{n}^{\circ}$ 82, de 1995, a então deputada federal Rita Camata defendeu a centralidade de regras jurídicas para restrição da discricionariedade de autoridades fiscais no caso de despesas com pessoal da seguinte forma: "trata-se acima de tudo de estabelecer um máximo de dispêndio orçamentário com custeio do funcionalismo. [...] cremos ter indicado um caminho para acabar com essa orgia de gastos" (DCN, 22 de março de 1989, Seção I, p. 1.356).

Exatamente no mesmo sentido, o então Conselheiro Pedro Malan, no Conselho Monetário Nacional, apresentou as seguintes declarações - constantes do Voto $\mathrm{n}^{\circ} 162$, de 1995, que posteriormente seria usado como a base do Programa de Apoio à Reestruturação e ao Ajuste Fiscal dos Estados, implementado pela Lei no 9.496/1997:

O programa ora proposto visa à implementação de medidas que permitam aos estados alcançar o equilíbrio orçamentário sustentável. De nada adiantaria possibilitar refinanciamentos sem que, simultaneamente, fossem eliminadas as fontes de desequilíbrio fiscal e financeiro. Sem esse esforço, a situação de inadimplência e desajuste tenderia a repetir-se. ${ }^{65}$

As palavras talvez sejam mais amenas do que as usadas pela Deputada Rita Camata, mas a mensagem era clara: o ajuste fiscal das contas estaduais era necessário para que novos refinanciamentos fossem aprovados.

Anos mais tarde, em abril de 1999, o então presidente Fernando Henrique Cardoso justificou a proposta de aprovação da Lei de Responsabilidade Fiscal ao Congresso Nacional com mensagem semelhante:

Este projeto de lei - publicamente conhecida como Lei de Responsabilidade Fiscal - LRF - também faz parte desse elenco de importantes inovações estruturais da Administração Pública que, após aprovado, terá vigência num ambiente fiscal mais favorável, sedimentado pelos efeitos positivos do Programa de Estabilidade Fiscal, da reestruturação das dívidas dos estados e dos municípios, da reorganização do sistema bancário estadual, e de outras medidas de

\footnotetext{
${ }^{65}$ A íntegra do voto está disponível em: <https://www.fazenda.gov.br/divulgacao/publicacoes/conselhomonetario-nacional-cmn/cmn-no-162-95> (último acesso em 5 de outubro de 2014).
} 
ajuste fiscal implementadas pelos governos estaduais e municipais. (Mensagem no 485 de 13 de abril de 1999) ${ }^{66}$

Como a passagem acima resume, as autoridades do governo federal pressionavam pela aprovação de "inovações estruturais" que buscavam promover a agenda do ajuste fiscal no país. A aprovação da Lei de Responsabilidade Fiscal no Congresso era "parte desse elenco" de medidas de ajuste fiscal, implementadas não só pelo governo federal, mas também pelos governos estaduais e municipais. É por isso que a exposição de motivos encaminhada pelo então presidente continuava da seguinte forma:

a combinação desse ambiente fiscal mais favorável com a aprovação de uma norma que estabelece princípios norteadores da gestão fiscal responsável, que fixa limites para o endividamento público e para a expansão de despesas continuadas, e que institui mecanismos prévios e necessários para assegurar o cumprimento de metas fiscais a serem atingidas pelas três esferas de governo é a condição necessária e suficiente para a consolidação de um novo regime fiscal no País, compatível com a estabilidade de preços e o desenvolvimento sustentável (DCD, 1999, p. 15154).

Em um contexto em que as próprias autoridades se referiam ao projeto da Lei de Responsabilidade Fiscal como "a condição necessária e suficiente para a consolidação de um novo regime fiscal no país", o objetivo desta seção é organizar as regras e princípios jurídicos consolidados com a lei e que constituem o que se vem chamando de novo regime jurídico da política fiscal. A discussão mais específica sobre as determinantes da reforma será apresentada no próximo capítulo. Nele, a hipótese sobre a importância da agenda do ajuste fiscal será explorada em mais detalhes.

Para facilitar a apresentação do novo regime jurídico da política físcal, consolidado com a Lei de Responsabilidade Fiscal, esta seção não trabalhará com a aprovação cronológica das regras e princípios, mas proporá uma divisão baseada em quatro diferentes níveis de regras e princípios que sofreram uma reforma substantiva. A proposta deste capítulo para organizar regras é propositalmente parcial: ela não lidará

\footnotetext{
${ }^{66}$ Publicada no Diário da Câmara dos Deputados (DCD) do dia 14 de abril de 1999, pp. 15154-15189.
} 
com o contexto de sua aprovação, que será discutido em detalhes no capítulo 3, nem com os seus efeitos, que serão discutidos no capítulo 4.

A organização das regras e princípios jurídicos modificados na década de 1990 demonstra que, embora o principal objetivo da reforma da década de 1990 fosse promover a agenda do ajuste fiscal e da sustentabilidade da dívida pública, a reforma abrangeu a mudança de diversas regras e princípios relativos à relação federativa na gestão fiscal, à relação entre o Legislativo e o Executivo, à transparência e à fiscalização das contas públicas, além de regras que efetivamente buscam estabelecer limitações para opções de política fiscal.

Nesse contexto, na organização das regras e princípios jurídicos criados no período, esta pesquisa diferencia quatro âmbitos de reforma, que serão apresentados nas próximas subseções: centralização do poder fiscal na União, em comparação com estados e municípios; centralização do poder fiscal no Executivo; regras que estabelecem limites para as decisões fiscais do setor público consolidado; novos mecanismos de transparência. A lista de regras e princípios criados não pretende ser exaustiva. Seu objetivo é apontar as principais modificações jurídicas que foram essenciais para promoção da reforma do regime jurídico da política fiscal.

\subsubsection{Regras e princípios centralizando o poder fiscal na União}

A primeira dimensão que foi alterada se relaciona ao federalismo. Novas regras e novos princípios concederam maior poder à União para controlar as dívidas estaduais e municipais. Em síntese, na década de 1990, o novo regime jurídico da política fiscal passou a prever:

(i) que bancos públicos estaduais não poderiam conceder empréstimos aos agentes públicos que os controlavam - prática que era comum na década de 1980 e no início da década de 1990 e que colocava em risco qualquer comprometimento de disciplina fiscal do setor público consolidado - artigo 36 da Lei de Responsabilidade Fiscal;

(ii) a privatização de empresas estatais estaduais e dos bancos públicos estaduais como pré-requisito para o recebimento de recursos pela União - Medida Provisória no 1.514/1996, que instituiu o Programa de Incentivo à Redução do Setor Público Estadual na Atividade Bancária 
(PROES) e Lei $\mathrm{n}^{\circ}$ 9.496/1997, que determinou as condições do Programa de Apoio à Reestruturação e ao Ajuste Fiscal dos Estados;

(iii) a proibição de transações creditícias entre entidades da Federação artigo 35 da Lei de Responsabilidade Fiscal;

(iv) outros limites para operações de crédito - além das vedações discutidas no item (i) e no item (iii), a Lei de Responsabilidade Fiscal proibiu operações de crédito, como a captação de recursos a título de antecipação de receita de tributo ou contribuição cujo fator gerador não tenha ocorrido e o recebimento antecipado de valores de empresa em que o Poder Público detenha, direta ou indiretamente, a maioria do capital social com direito a voto, e restringiu outras operações, como as a operação de crédito por antecipação de receita orçamentária artigos 34 a 42 da Lei de Responsabilidade Fiscal;

(v) limites para gastos com pessoal - artigo 19 da Lei de Responsabilidade Fiscal prevê que a União poderá ter como despesa total com pessoal o percentual de $50 \%$ da receita corrente líquida, enquanto Estados e municípios 60\%; já o artigo 20, o mais questionado perante o Supremo Tribunal Federal, como se verá abaixo, estabeleceu limites específicos para gastos por cada um dos Poderes e pelo Ministério Público em cada uma das esferas federativas ${ }^{67}$;

(vi) a possibilidade de proibição da transferência voluntária de recursos para estados e municípios em caso de desrespeito às regras - artigos $11,23, \S 3^{\circ}$, I e II, e 51 da Lei de Responsabilidade Fiscal;

(vii) para o governo federal refinanciar as dívidas estaduais, os governos estaduais deveriam se comprometer junto ao governo federal a estabelecer metas quanto à dívida financeira em relação à receita líquida real, ao resultado primário, à arrecadação de receitas próprias,

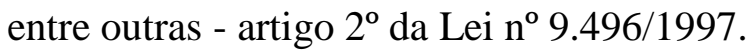

\footnotetext{
${ }^{67}$ Da seguinte forma: (i) na esfera federal: 2,5\% para o Legislativo, incluído o Tribunal de Contas; $6 \%$ para o Judiciário; 40,9\% para o Executivo; 0,6\% para o Ministério Público; (ii) na esfera estadual: 3\% para o Legislativo; 6\% para o Judiciário; 49\% para o Executivo; 2\% para o Ministério Público; (iii) na esfera municipal: $6 \%$ para o Legislativo; $54 \%$ para o Executivo.
} 
O papel do Supremo Tribunal Federal na consolidação de quase todas as regras apresentadas nessa lista foi fundamental. Logo após a aprovação da Lei de Responsabilidade Fiscal, três partidos - Partido Comunista do Brasil (PCdoB), Partido dos Trabalhadores (PT) e Partido Socialista Brasileiro (PSB) - pleitearam a inconstitucionalidade de diversos dispositivos da lei, entre eles os artigos 11 e 20, na Ação Direta de Inconstitucionalidade (ADI) no $2238 .{ }^{68}$ Os partidos argumentavam que o artigo 11 da lei, ao vedar a realização de transferências voluntárias para o ente que não instituísse, previsse e efetivasse a arrecadação de todos os tributos da sua competência constitucional feriria a vedação constitucional de reter ou condicionar a entrega de recursos das receitas tributárias prevista na Constituição (artigo 160 da CF). Quanto ao artigo 20, que estabeleceu limites específicos para gastos por cada um dos Poderes e pelo Ministério Público em cada uma das esferas federativas, argumentavam que ele feria o princípio do federalismo e da separação de poderes.

Paralelamente à ação dos partidos, o então governador de Minas Gerais, Itamar Franco, pleiteou perante o STF, por intermédio da ADI nº 2250, a inconstitucionalidade dos artigos que proibiam operações de crédito entre entes federados (art. 35) e a sanção de proibição do recebimento de transferências voluntárias quando um Estado não encaminhasse ao Poder Executivo da União as suas contas até o dia 31 de maio de cada ano (art. 51). Segundo o então governador, ambos os artigos feririam o princípio federativo.

O então Ministro Ilmar Galvão foi relator do julgamento das medidas cautelares nas duas ADIs. Em relação ao artigo 11, no julgamento da medida cautelar da ADI $n^{\circ}$ 2238-5, por unanimidade, o Tribunal declarou que "por se tratar de transferências voluntárias, as restrições impostas aos entes beneficiários que se revelem negligentes na instituição, previsão e arrecadação de seus próprios tributos não são incompatíveis com o art. 160 da Constituição Federal”. Já em relação ao artigo 20, vencidos o relator e os Ministros Sepúlveda Pertence, Octavio Gallotti, Néri da Silveira e o então presidente Carlos Velloso, o Supremo entendeu que "o art. 169 da Carta Magna não veda que se faça uma distribuição entre os Poderes dos limites de despesa com pessoal; ao contrário, para tornar eficaz o limite, há de se dividir internamente as responsabilidades", de

\footnotetext{
${ }^{68} \mathrm{O}$ PCdoB proporia nova ação direta de inconstitucionalidade contra os artigos relativos aos limites de gasto com pessoal, por meio da ADI $n^{\circ}$ 2365. As ADIs $n^{\circ} 2241,2256$ e 2261, propostas pela Mesa da Assembléia Legislativa do Estado de Minas Gerais, Associação dos Membros dos Tribunais de Contas do Brasil (ATRICON) e Associação Nacional dos Membros do Ministério Público (CONAMP), também foram apensadas à $\mathrm{ADI} \mathrm{n}^{\circ} 2238$, por discutirem o artigo que limita os gastos com pessoal.
} 
acordo com o voto dissidente do Ministro Nelson Jobim. ${ }^{69}$ No julgamento da medida cautelar da ADI no 2250, por unanimidade, o Supremo declarou que os artigos 35 e 51 são constitucionais, pois tratam de norma de gestão financeira, nos termos do inciso II do $\S 9^{\circ}$ do artigo 165 da Constituição Federal, e que, portanto, estão no âmbito de competência da União.

\subsubsection{Regras e princípios centralizando o poder fiscal no Executivo}

Regras regulando a relação entre Poder Executivo e Poder Legislativo também foram alteradas. O Executivo já era a principal autoridade fiscal no Brasil, como se argumentou na seção anterior, mas é possível afirmar que seus poderes foram fortalecidos por meio de dois dispositivos aprovados na década de 1990:

(i)

emendas constitucionais que permitem que o Executivo retenha certas receitas que a Constituição originalmente determinaria para certas despesas - as chamadas "desvinculações das receitas da União", previstas inicialmente pela Emenda Constitucional de Revisão n ${ }^{\circ}$ 1/1994, com o nome de Fundo Social de Emergência, e posteriormente renovadas por outras emendas constitucionais ${ }^{70}$;

(ii) regras da Lei de Responsabilidade Fiscal que permitem que o Executivo programe as despesas públicas por Decreto, após a aprovação da Lei Orçamentária Anual - artigos $8^{\circ}$ e $9^{\circ}$ da Lei de Responsabilidade Fiscal.

Ambas as possibilidades abertas ao Executivo dão proeminência a este poder na sua relação com o Legislativo no âmbito da política fiscal. A desvinculação das receitas da União permite que o governo use certas receitas, antes vinculadas, de modo discricionário. Em geral, o governo federal as utiliza para promoção do superávit primário, como se discutirá no capítulo 4. A doutrina jurídica brasileira costuma ser extremamente crítica à desvinculação das receitas da União, apresentando inclusive argumentos quanto à sua inconstitucionalidade (OLIVEIRA, 2013, p. 449).

\footnotetext{
${ }^{69} \mathrm{O}$ argumento contrário era de que o artigo 169 da Constituição só permitiria o estabelecimento de tetos para gastos com pessoal, e não a discriminação de limites por poder e por esfera federal, como prevê o artigo 20 da Lei de Responsabilidade Fiscal.

70 A apresentação de cada uma das emendas será feita no capítulo 4. É importante mencionar que o mecanismo da desvinculação de receitas da União faz parte dos mecanismos discutidos nesta dissertação porque ele diz respeito à possibilidade de que o Executivo gaste como o recurso como quiser, ao invés de modo vinculado. Nesse sentido, a desvinculação é regra relativa às despesas públicas e não à arrecadação.
} 
As duas regras foram fortalecidas graças a duas importantes interpretações tradicionais do direito financeiro e do direito internacional brasileiro, que permanecem hegemônicas na prática financeira e internacional do país até hoje. Primeiramente, na maior parte da doutrina do direito financeiro brasileiro e na prática orçamentária, as leis orçamentárias não são consideradas mandatórias, sendo meramente autorizativas, assunto que será desenvolvido no capítulo 4. A segunda interpretação tradicional que favorece a proeminência do Executivo é derivada de certa doutrina do direito internacional, aceita na prática internacional e doméstica, que defende como único responsável por assinar um acordo stand-by com o Fundo Monetário Internacional o Poder Executivo. Este tema será discutido no próximo capítulo.

Mais uma vez, o Supremo Tribunal Federal foi essencial na legitimação e estabilização das referidas regras. No caso da desvinculação das receitas da União, a Segunda Turma do Tribunal declarou, por unanimidade, que "não é inconstitucional a desvinculação de parte da arrecadação de contribuição social, levada a efeito por emenda constitucional" (Relator Ministro Cezar Peluso, Recurso Extraordinário $\mathrm{n}^{\circ}$ 537.610, DJE 18.12.2009). Segundo o voto do Relator, não há incompatibilidade entre a desvinculação e o restante do texto constitucional - argumento que é geralmente ressaltado pela doutrina que defende sua inconstitucionalidade - e a norma que determina a vinculação das contribuições sociais não é cláusula pétrea.

Quanto à possibilidade de que o Executivo programe as despesas públicas por decreto, como se verá adiante, o STF declarou inconstitucional parte de um dos dispositivos relevantes da prerrogativa, embora o seu núcleo tenha sido preservado. Trata-se de prerrogativa ampla, que permite ao Executivo inclusive a não realização de gastos previstos na Lei Orçamentária aprovada, sem qualquer justificação, como também se demonstrará no capítulo 4. Dentre as competências relativas a essa prerrogativa, o artigo $9^{\circ}$ da Lei de Responsabilidade Fiscal prevê que, caso a realização da receita não comporte o cumprimento de metas orçamentárias estabelecidas em Lei, a qualquer tempo, "os Poderes e o Ministério Público promoverão, por ato próprio e nos montantes necessários, nos trinta dias subseqüentes, limitação de empenho e movimentação financeira, segundo critérios fixados na LDO". A Lei ainda determinava que, caso os Poderes Legislativo e Judiciário e o Ministério Público não efetuassem o contingenciamento, o Poder Executivo deveria fazê-lo ( $\$ 3^{\circ}$ do art. $9^{\circ}$ da LRF).

No julgamento da Medida Cautelar na ADI no 2.238, acima referida, o Supremo Tribunal Federal suspendeu o parágrafo que permitia ao Executivo o contingenciamento 
quando os Poderes Legislativo, Judiciário e o Ministério Público não o efetuassem. Por unanimidade, o tribunal entendeu que o artigo era inconstitucional, uma vez que ele viabilizaria ao Executivo uma interferência indevida nos Poderes Legislativo e Judiciário.

\subsubsection{Regras e princípios definindo limites para a política fiscal}

No Brasil, em especial após a Lei de Responsabilidade Fiscal, mas já a partir da Constituição Federal de 1988, a gestão da política fiscal passou a contar com diversas limitações jurídicas, algumas já discutidas na subseção 2.2.1:

(i) o objetivo da gestão fiscal seria a responsabilidade, que pressupõe a ação planejada e transparente, em que se previnem riscos e corrigem desvios capazes de afetar "o equilíbrio das contas públicas" - artigos $1^{\circ}$ e $2^{\circ}$ da Lei de Responsabilidade Fiscal;

(ii) o governo só pode incorrer em déficits que sejam equivalentes ao montante de investimentos - artigo 167, III da Constituição e artigo $12, \S 2^{\circ}$ da Lei de Responsabilidade Fiscal;

(iii) o Banco Central não pode financiar o Tesouro Nacional - artigo 164, $\S 1^{\text {o }}$, da Constituição e artigos $7^{\circ}$ e 34 da Lei de Responsabilidade Fiscal;

(iv) existem limites para os gastos públicos com pessoal - ver subseção 2.2.1., acima;

(v) a criação, expansão ou aperfeiçoamento de ações governamentais que impliquem aumento de despesas deve ser acompanhado da estimativa do impacto orçamentário-financeiro para o exercício que entrar em vigor e nos dois subsequentes, além de declaração do ordenador de despesa de que o referido aumento é compatível com o PPA e a LDO e é adequado à LOA - artigos 16 e 17 da Lei de Responsabilidade Fiscal;

(vi) gastos continuados de mais de dois anos só podem ser aprovados com a indicação específica da fonte de seu financiamento - artigo 17 da Lei de Responsabilidade Fiscal;

(vii) a Lei de Diretrizes Orçamentárias deve incluir um anexo de metas fiscais no qual metas relativas a gastos públicos, resultados primário e 
nominal e para o montante de endividamento público devem ser apresentados para os próximos três anos - artigo $4^{\circ}$ da Lei de Responsabilidade Fiscal;

(viii) o Senado passou a determinar limites para o nível global de dívida pública em todas as esferas do governo e deixou de analisar os pedidos de autorização para a contratação de qualquer operação de crédito de tomador que apresente resultado primário negativo ou que esteja inadimplente junto a instituições integrantes do Sistema Financeiro Nacional - artigos 30, 32, 40 e 66 da Lei de Responsabilidade Fiscal e Resoluções do Senado no 78/1998 e $n^{\circ} 43 / 2001$.

Mais uma vez, o STF foi essencial na consolidação dessas regras, em especial daquelas previstas nos artigos $4^{\circ}, 7^{\circ}, 12$ e 17 da Lei de Responsabilidade Fiscal. Os partidos que ingressaram com a ADI $n^{\circ} 2238$ perante o STF argumentaram que os referidos artigos seriam inconstitucionais. O artigo $4^{\circ}$, ao obrigar Estados e Municípios a demonstrarem viabilidade das metas programadas em face das diretrizes de política econômica do Governo Federal, feriria o princípio federativo. $\mathrm{O}$ artigo $7^{\circ}$, ao disciplinar a relação entre Banco Central e Tesouro Nacional, seria norma vinculada ao Sistema Financeiro Nacional e, portanto, não poderia estar incluída em uma lei complementar sobre Finanças Públicas, além de constituir possibilidade de criação de créditos ilimitados para o Poder Público, em particular na hipótese do Tesouro cobrir eventuais resultados negativos do Banco Central. Os partidos ainda alegaram que o artigo 12 ignorava exceções expressamente possibilitadas pela Constituição na aplicação da "regra de ouro" das finanças públicas e que o artigo 17 desrespeitava tanto o princípio da separação de poderes como o princípio federativo, em particular na imposição de regras específicas para despesas obrigatórias de caráter continuado, que, segundo a lei, deveriam passar a ser compensadas pelo aumento permanente de receita ou pela redução permanente de despesa.

Por unanimidade, o STF rejeitou os pedidos relativos aos artigos $4^{\circ}, 7^{\circ}$ e 17 , e concedeu interpretação conforme a Constituição ao artigo 12 no julgamento da medida cautelar da ADI, nos termos do voto do relator, Ministro Ilmar Galvão. Os ministros do STF entenderam que a demonstração da viabilidade das metas programadas pelos Estados e Municípios no contexto das políticas econômicas de crédito, juros e das 
previsões de inflação, crescimento, entre outras, do governo federal, não fere qualquer dispositivo constitucional (art. $4^{\circ}$ ), uma vez que essa demonstração é medida de gestão e planejamento, não de intervenção da União nos outros entes federativos. Para a Corte, a regra sobre o relacionamento entre Banco Central e Tesouro (art. $7^{\circ}$ ) também é constitucional. Trata-se de regra de natureza fiscal que não cria créditos ilimitados para o poder público, pois as hipóteses de o Tesouro cobrir eventuais resultados negativos do Banco Central são específicas e restritas. Quanto às regras sobre despesas obrigatórias de caráter continuado, o STF entendeu que condicionar o seu aumento "à redução de despesa ou aumento de receita, também em caráter continuado" é proposta que "não pode ser obviamente considerada responsável pelo engessamento de qualquer dos Poderes de Estado". Nesse sentido, o Supremo declarou que as regras não feriam o princípio da separação dos Poderes e o princípio da autonomia dos entes federados.

Por fim, em relação à "regra de ouro" das finanças públicas, que nos termos da LRF proíbe que "o montante previsto para as receitas de operações de crédito" seja "superior ao das despesas de capital constantes do projeto de lei orçamentária" (art. 12), o STF deu interpretação conforme a Constituição à regra, para explicitar que a vedação não abrange a abertura de créditos suplementares ou especiais com finalidade precisa, aprovados pelo Poder Legislativo, hipóteses já expressamente permitidas pela regra constitucional, nos termos do inciso III do art. 167.

Analisar as resoluções do Senado Federal também é essencial para se compreender o avanço de regras relacionadas ao ajuste fiscal no período (LOUREIRO, 2001; LEITE, 2005). Como observa Loureiro, o Senado produziu ao longo da década de 1990 "um conjunto de normas cada vez mais restritivas para o endividamento dos governos" (2001, p. 56). Dentre todas as Resoluções aprovadas pela Casa relativas ao tema, no âmbito de sua esfera de competência prevista pelo artigo 52 da Constituição Federal, destacam-se duas: a Resolução nº 78/1998 e a Resolução no 43/2001.

A primeira Resolução foi criada logo após a aprovação da Lei de refinanciamento das dívidas estaduais, aprovada em 1997, e previa regras que proibiam o Banco Central de encaminhar ao Senado pedidos de autorização para a contratação de qualquer operação de crédito de governo que possuísse resultado primário negativo ou que houvesse concedido isenções fiscais sobre o ICMS. Posteriormente, a Resolução $\mathrm{n}^{\circ}$ 43/2001 transferiu a competência para análise dos pedidos de autorização para a contratação de qualquer operação de crédito de governo do Banco Central para a Secretaria do Tesouro Nacional (ABRUCIO e LOUREIRO, 2002; LEITE, 2005). 


\subsubsection{Regras e princípios de transparência e prestação de contas da política fiscal}

A quarta dimensão de mudança foi a criação de regras específicas de transparência e prestação de contas da política fiscal, em particular após a aprovação da Lei de Responsabilidade Fiscal. Essas regras obrigam as entidades federativas a:

(i) tratarem a transparência da gestão fiscal como o objetivo principal a ser perseguido - artigo 48 da LRF;

(ii) conduzirem audiências públicas e encorajarem a participação pública nos processos de elaboração e discussão dos planos, lei de diretrizes orçamentárias e orçamentos - artigo 48, parágrafo único da $\mathrm{LRF}^{71}$;

(iii) respeitarem normas específicas sobre escrituração e consolidação das contas públicas - artigos 50 e 51 da LRF;

(iv) publicarem relatórios sobre execução orçamentária a cada dois meses - artigos 52 e 53 da LRF;

(v) publicarem relatórios de gestão fiscal ao final de cada quadrimestre artigos 54 e 55 da LRF;

(vi) (somente para o governo federal) criar um conselho fiscal para supervisionar e avaliar a gestão fiscal - artigo 67 da LRF.

O STF não foi provocado para decidir sobre qualquer uma dessas regras, com exceção da previsão do $\S 1^{\circ}$ do artigo 51 , que dispõe sobre o envio das contas dos Municípios e dos Estados à União, para consolidação, discutida acima na subseção 2.2.1.. A regra que previu a criação do conselho de gestão fiscal nunca foi implementada. $^{72}$

Além dessas regras sobre transparência, a LRF ainda dispôs sobre o papel do Poder Legislativo e, em especial, dos Tribunais de Conta na análise das prestações de contas dos poderes e na fiscalização da gestão fiscal. Nessas duas funções, a Lei de Responsabilidade Fiscal atribuiu aos Tribunais de Conta as competências para emitir parecer prévio conclusivo sobre as contas prestadas pelo Chefe do Executivo, no prazo de sessenta dias do recebimento (art. 56 e 57), e para alertar os Poderes e Ministério Público em casos de desrespeito a alguns limites fiscais estabelecidos na lei.

\footnotetext{
${ }_{71}^{71}$ Posteriormente alterado pela Lei Complementar $n^{\circ} 131$, de 2009, que será discutida no capítulo 4.

${ }^{72}$ Ver a discussão sobre o conselho no capítulo 4.
} 


\subsection{As determinantes do novo regime e a indeterminação do direito}

Consideradas conjuntamente, as quatro dimensões da reforma indicam que um novo regime jurídico para a política fiscal foi construído no Brasil nas últimas décadas. Novas regras e novos princípios jurídicos alteraram a relação federativa, as prerrogativas entre Executivo e Legislativo, os requisitos de transparência e a própria natureza da política fiscal (de discricionária para baseada em regras e metas). ${ }^{73}$ Nesse sentido, o regime jurídico não somente impôs novos deveres e restrições para a política fiscal, mas também alterou o poder dos atores responsáveis por implementar a política.

O estudo do regime jurídico da política fiscal aprovado no país demonstra que ele foi alterado nos principais aspectos considerados centrais para a literatura internacional sobre regras fiscais, apresentada no capítulo 1: (i) o Brasil aprovou regras que estabelecem restrições ex ante para a política fiscal, como a demanda por aprovação de metas vinculantes para o setor público consolidado; (ii) o governo federal centralizou a autoridade fiscal e hierarquizou o processo de aprovação de despesas, tanto em relação aos entes subnacionais como em relação ao Poder Legislativo; (iii) procedimentos de transparência da gestão das finanças públicas, em particular relacionados com os objetivos de promoção da sustentabilidade da dívida pública no médio prazo, foram aprovados.

Dentro do escopo definido para este trabalho, ainda restam duas questões para serem analisadas: (i) quais foram as determinantes de aprovação dessa reforma?; (ii) como a criação desse novo regime jurídico da política fiscal impactou os resultados desejados pelos que propuseram a reforma?. Os próximos dois capítulos tentam investigar em detalhes essas duas perguntas.

O capítulo 3 tentará demonstrar que o objetivo central da reforma, como já argumentado neste capítulo, foi a promoção do ajuste fiscal no país. Contudo, como se demonstrará, esse discurso é menos autônomo e endógeno às condições domésticas do Brasil do que geralmente costuma se admitir na literatura da ciência política sobre o tema. Sem dúvidas, diversas características e peculiaridades locais determinaram a aprovação do novo regime nos termos em que ele foi apresentado neste capítulo. Porém, há uma dinâmica internacional que influenciou fortemente a aprovação do novo regime

\footnotetext{
${ }^{73}$ Sobre a mudança da natureza da política fiscal, ver: Kopits (2004), especialmente o capítulo por Goldfajn e Guardia.
} 
jurídico da política fiscal que ainda precisa ser melhor estudada, e que, em termos gerais, se relaciona ao problema de inserção de um país no capitalismo mundial.

$\mathrm{O}$ argumento do próximo capítulo é muito semelhante àquele desenvolvido por Sylvia Maxfield para a política monetária em seu livro Gatekeepers of growth. No livro de Maxfield, a autora argumenta que quanto mais a globalização financeira se intensifica, mais os políticos tentam sinalizar a investidores internacionais que investir em seus países é uma vantagem, o que afetaria a aprovação de leis estruturando a independência do Banco Central (MAXFIELD, 1997, p. 5 e especialmente, o capítulo 3, pp. 35 - 50). Na dinâmica de aprovação da Lei de Responsabilidade Fiscal no país, a ideia de sinalização foi central. Na realidade, a arena internacional teve um papel muito mais relevante para a aprovação do regime do que normalmente se admite.

Ainda que se demonstre que a interação entre elementos domésticos e internacionais foi fundamental para a reforma do regime jurídico da política fiscal, uma série de questões permanece aberta. Caso a hipótese de que o regime resultante dessa interação tenha sido alterado nos quatro âmbitos delineados por esse capítulo estiver correta, quais foram os impactos que puderam ser percebidos após a aprovação dessas novas regras e princípios? Em cada um dos âmbitos de reforma, os efeitos estão de acordo com os objetivos daqueles agentes que incentivaram a reforma? Quais dessas regras e princípios foram centrais na implementação do regime nos anos que sucederam a reforma?

Sobre essas perguntas, a hipótese que conduzirá os estudos do capítulo 4 deriva de reflexões no âmbito da teoria e da sociologia do direito, que tratam do tema da indeterminação do direito. O conceito de indeterminação do direito tende a explicitar que o momento de sua determinação provavelmente nunca se completa com a mera previsão legal ou constitucional de regras e princípios jurídicos; o momento (contínuo) da aplicação - ou da interpretação - do direito é tão essencial quanto o da "criação" do direito. ${ }^{74}$ Em outras palavras, trata-se da discussão a respeito da mudança da função do

\footnotetext{
${ }^{74} \mathrm{O}$ tema da indeterminação do direito talvez seja uma das formas mais interessantes de se aproximar dos principais debates da teoria e da sociologia do direito. Basta pensar nos seguintes exemplos: o debate sobre a materialização do direito iniciado por Max Weber e as questões de segurança e previsibilidade jurídicas para o desenvolvimento do capitalismo ocidental; o último capítulo da Teoria Pura do Direito, em que Kelsen anuncia que é impossível determinar juridicamente a interpretação do direito em uma decisão efetiva; ou, ainda, o clássico debate entre Hart e Dworkin a respeito da discricionariedade jurisdicional. Teóricos do direito brasileiro vêm dando diferentes interpretações ao tema, a partir de diferentes pontos de vista teóricos. Dois exemplos recentes são: Barbosa (2013) discute a questão da indeterminação social do direito a partir da ideia de que se multiplicaram as arenas decisórias especializadas na estabilização das expectativas normativas e as lutas por justificação sobre a interpretação política das normas jurídicas e que ainda não está claro se a Constituição Federal, com seus
} 
direito, segundo a qual, a despeito da modificação de artigos de lei ou até mesmo da constituição, os próprios institutos jurídicos podem ter seu funcionamento substantivamente alterado a partir da influência de outras transformações políticas, sociais e econômicas (NEUMANN, 1957, 1986).

No caso do regime jurídico da política fiscal, talvez a interpretação da qual se esteja tratando não corresponda à ideia geralmente compartilhada por juristas a respeito do tema. Os órgãos judiciais parecem ter importância secundária na aplicação do regime jurídico da política fiscal, embora tenham sido fundamentais para consagrar a constitucionalidade das regras e dos princípios. A ausência do Judiciário como órgão de aplicação do direito, entretanto, não torna o direito da política fiscal menos indeterminado: trata-se simplesmente de deslocar o âmbito das decisões a respeito de como melhor implementar as diversas normas jurídicas do regime da política fiscal do Poder Judiciário para alguma outra instituição. Caso a narrativa apresentada até aqui esteja correta, trata-se de dizer que o local de interpretação do direito da política fiscal ou, traduzido em termos mais simples, da definição da gestão da política fiscal - se concentrou no Ministério da Fazenda e na Secretaria do Tesouro Nacional, com certas limitações e com a criação de novos mecanismos de transparência. Por isso a importância do Judiciário não seria tão grande.

Nesse caso, contudo, resta analisar se as regras e os princípios jurídicos criados foram capazes de determinar a prática da política fiscal tanto quanto os agentes da reforma desejavam, em especial se o seu objetivo era o de promoção do ajuste fiscal de forma permanente. Esta é a pergunta que se tentará responder no capítulo 4. O próximo capítulo se preocupará em discutir os objetivos da reforma, a partir da análise da interação entre fatores domésticos e internacionais que resultaram em sua aprovação.

diversos princípios, consegue se infiltrar nessas arenas decisórias; em sentido semelhante, Rodriguez (2013) demonstra como a participação do Judiciário se torna central em uma sociedade plural e democrática para garantir que a interpretação do direito esteja sempre aberta a novas lutas por justificação. 


\section{Capítulo 3 - A reforma do regime jurídico da política fiscal no contexto do ajuste: fatores domésticos e influências internacionais}

O capítulo anterior apresentou o que esta pesquisa vem chamando de um novo regime jurídico para a política fiscal gestado ao longo das décadas de 1980 e 1990 no Brasil e consolidado com a aprovação da Lei de Responsabilidade Fiscal em 2000. Argumentou-se também que, a partir de 1990, a reforma do regime jurídico da política passou a estar conectada a uma agenda de ajuste fiscal, o que não se verificou no período anterior. Contudo, o capítulo anterior não aprofundou a discussão sobre a conexão entre os objetivos da reforma da década de 1990 e as regras e os princípios jurídicos criados.

Com o escopo de avançar na análise das possíveis determinantes da reforma do regime da política fiscal no Brasil, este capítulo explora as variáveis usadas na literatura sobre o tema. Acredita-se que essa análise mais apurada dos fatores que influenciaram a criação de um regime jurídico permita esclarecer quais foram os principais objetivos, atores e disputas em um momento de intensa reforma jurídica.

Pouca atenção tem sido dada a elementos internacionais nas variáveis usualmente consideradas relevantes na reforma do regime jurídico da política fiscal. ${ }^{75} \mathrm{~A}$ literatura tende a se concentrar somente ou principalmente nos elementos domésticos que resultaram em sua criação. ${ }^{76}$ Quando fatores internacionais são levados em consideração, a literatura tende a interpretá-los por meio de um elevado nível de abstração. Essas abordagens não costumam explorar as dinâmicas jurídicas, políticas e econômicas presentes na interação entre elementos domésticos e internacionais na reforma. Desse modo, este capítulo tenta contribuir com a literatura ao discutir como atores domésticos interagiram ativamente com a arena internacional na defesa da reforma.

A hipótese é a de que fatores domésticos e internacionais são fundamentais para uma descrição do processo de reforma do novo regime jurídico para a política fiscal e, em especial, para a aprovação da Lei de Responsabilidade Fiscal, que a consolidou. No plano doméstico, elites políticas iniciaram a discussão pública sobre a necessidade de um ajuste fiscal para o país ainda na década de 1980, como se demonstrou no capítulo anterior. Porém, somente em 1994, com a aprovação do Plano Real, o governo federal

\footnotetext{
${ }^{75}$ A literatura sobre o tema geralmente não utiliza essa expressão para se referir à aprovação das regras e princípios jurídicos para a política fiscal.

${ }^{76}$ Ver principalmente: Abrucio e Asazu (2003), Asazu (2003), Leite (2005) e Abrucio e Loureiro (2002).
} 
foi capaz de colocar essa pauta como prioritária na agenda nacional, o que incluiu a aprovação de um novo regime jurídico para a política fiscal, com todas as regras discutidas na seção 2.2. do capítulo anterior.

É essencial diferenciar a agenda mais ampla do ajuste fiscal no país - que envolveu transformações substantivas em diversas áreas, incluindo privatizações e concessões, reformas da previdência pública, ampla reforma do Estado, criação de tributos, entre outros - do novo regime jurídico da política fiscal que é o objeto desta pesquisa. Este regime se circunscreve ao conjunto de princípios e regras jurídicos descritos no capítulo 2. Os elementos que serão estudados aqui se relacionam prioritariamente a ele e não à agenda do ajuste fiscal como um todo.

A distinção entre a agenda mais ampla do ajuste fiscal e a reforma do regime jurídico da política fiscal é importante porque este capítulo analisa principalmente a aprovação da Lei de Responsabilidade Fiscal no país. Outras leis e decisões administrativas e judiciais que foram aprovadas e que modificaram o regime jurídico da política fiscal ao longo da década de 1990, apresentadas na seção anterior, também serão discutidas à medida que isso for necessário. Entretanto, esta dissertação interpreta a Lei de Responsabilidade Fiscal como a legislação de consolidação do novo regime jurídico para a política fiscal. Assim, é de se esperar que as influências internacionais na aprovação do regime jurídico para a política fiscal sejam mais facilmente apreendidas na aprovação da LRF do que no caso de outras leis ou decisões judiciais e administrativas.

Para compreender as influências internacionais na reforma do regime jurídico, o capítulo fez uso dos debates legislativos da aprovação da Lei de Responsabilidade Fiscal no Congresso Nacional, dos documentos publicados pelo Poder Executivo sobre o Programa de Estabilidade Fiscal, de 1998, de notícias dos jornais O Estado de São Paulo, Folha de São Paulo e $O$ Globo, e dos documentos do acordo stand-by entre Brasil e Fundo Monetário Internacional (FMI) disponíveis no sítio eletrônico do órgão internacional. $^{77}$

\footnotetext{
${ }^{77}$ Um acordo stand-by é um instrumento de empréstimo do FMI considerado necessário para um país que enfrenta problemas na sua balança de pagamentos. Ele é formalizado por meio de uma Carta de Intenções. Esta carta é geralmente assinada pelo Ministro da Fazenda do país que requer o acordo, embora o presidente do Banco Central ou o Primeiro Ministro/Presidente também possam assinar a Carta de Intenções. Um Memorando de Políticas Econômicas e um Memorando Técnico de Entendimento são anexos à carta de intenções. A literatura jurídica sobre a relação entre Brasil e FMI tende a se focar em questões normativas a respeito do papel do Legislativo na aprovação de acordos com o órgão.Geralmente não há uma descrição empírica dos impactos dos acordos nos vários âmbitos de regulação jurídica doméstica, como se pretende aqui no caso do regime jurídico da política fiscal. Ver, nesse sentido,
} 
A partir dessa delimitação, o argumento potencialmente novo desta dissertação é a explicitação de quatro vetores de influências internacionais na aprovação da Lei de Responsabilidade Fiscal. O primeiro vetor de influência é a de que o contexto internacional serviu de catalisador para acelerar a aprovação do novo regime jurídico para a política fiscal, sobretudo por conta das crises dos Tigres Asiáticos em 1997 e da Rússia em 1998. Em um ambiente de crises e incerteza do mercado global, o governo tentou promover uma agenda de reformas que permitiria a "diferenciação do país em relação a outros países emergentes", como definiria o próprio governo na apresentação do Programa de Estabilidade Fiscal, em 1998. Uma das reformas necessárias para a transição para um "novo regime fiscal" era a criação de regras jurídicas para a política fiscal, algo que já havia sido testado por outros países, em especial países desenvolvidos. Assim, experiências internacionais anteriores com a aprovação de regras jurídicas para a política fiscal forneceram um padrão de excelência e comparação para a reforma do regime jurídico brasileiro, o que representa o segundo vetor de influência internacional identificada. O terceiro vetor de influência internacional está implícito na descrição das influências anteriores: um dos motivos frequentemente mencionados como centrais para entender a necessidade de aprovação de um novo regime jurídico para a política fiscal, nos discursos parlamentares e nas notícias de jornais da época, é o de que a aprovação sinalizaria para investidores internacionais a vontade do governo brasileiro de manter a dívida pública sob controle. ${ }^{78}$ Nesse sentido, o governo federal brasileiro estava realmente disposto a reduzir sua margem de discricionariedade na gestão fiscal na tentativa de atrair o capital internacional. Por fim, o quarto vetor de influência verificado é o de que o acordo stand-by entre Brasil e FMI, em 1998, alavancou os esforços do governo federal para aprovar a lei contra eventuais opositores.

Embora o argumento deste capítulo inove na discussão específica sobre a aprovação do regime jurídico da política fiscal no Brasil, ele é inspirado em três ideias que já estavam presentes na literatura anterior sobre o tema e que estão sendo reaproveitadas para o contexto específico deste estudo.

A primeira ideia que influenciou a análise deste capítulo, já antecipada, é inspirada em um estudo semelhante apresentado por Sylvia Maxfield em sua pesquisa sobre a independência dos Bancos Centrais em diversos países. Em síntese, o

Mazzuoli (2005), Macedo (2007), Mazzuoli e Silva (2003). A literatura internacional sobre FMI sugere que a alegação de que a Carta de Intenções é inteiramente elaborada pelo FMI é comum (VREELAND, 2007, p. 32).

${ }^{78}$ Sinalização não deve ser confundida com imposição, como se argumentará ao longo deste capítulo. 
argumento central do livro da autora, exposto em detalhes no capítulo 3 da obra, é de que as regras sobre independência do Banco Central foram desenvolvidas em um contexto no qual políticos buscavam sinalizar a potenciais investidores internacionais a credibilidade da política monetária de sua nação (MAXFIELD, 1997). Interessada em explicar a variação encontrada da independência de bancos centrais ao redor do mundo, a autora apresenta a hipótese de que os políticos recorrem ao mecanismo da sinalização argumentando a favor da independência do Banco Central de acordo com quatro critérios: (i) quanto mais o país dependa de suporte externo para equilibrar a balança de pagamentos; (ii) quanto mais efetiva for a expectativa de que a sinalização funcionará; (iii) quanto mais seguros eles estejam em sua posição de políticos; (iv) quanto menores as restrições em transações financeiras internacionais (MAXFIELD, 1997, p. 4). Como se perceberá, esses elementos também estão presentes no caso brasileiro, na aprovação da Lei de Responsabilidade Fiscal, em especial os elementos (ii) e (iii). ${ }^{79}$ É possível supor que uma agenda de pesquisa focada não somente na independência dos bancos centrais, mas também nas reformas dos regimes jurídicos da política fiscal tenha resultados interessantes para compreender a evolução da gestão das políticas macroeconômicas e, por consequência, do capitalismo, no final do século XX e início do século XXI.

A segunda ideia que inspira a narrativa deste capítulo advém da literatura internacional sobre acordos stand-by entre FMI e países emergentes. Como argumenta Vreeland (2004, 2007), acordos com o FMI em geral representam os interesses de financiadores internacionais independentes - que ajudam o FMI com acordos suplementares para os países endividados - e dos países centrais, em especial dos Estados Unidos. ${ }^{80}$ Nesse sentido, é comum o argumento de que um acordo com o organismo multilateral é geralmente resultado de uma imposição desses credores sobre os países que necessitam de crédito.

\footnotetext{
${ }^{79}$ A autora utiliza três mecanismos para testar se a explicação da sinalização ao investidor está ocorrendo: (i) analisa, no capítulo 4 da obra, a variação regional da política de independência do Banco Central e sugere que ela é condizente com as percepções dos políticos sobre as pressões financeiras internacionais; (ii) faz estudos de caso das histórias dos Bancos Centrais de Tailândia, México, Coreia do Sul e Brasil para testar o argumento; (iii) finalmente, apresenta resultados de um teste econométrico indireto para testar a explicação. Como se percebe, não é possível replicar nesta pesquisa, que é centrada somente no caso brasileiro, a metodologia utilizada pela autora. De qualquer modo, a narrativa de Maxfield para reproduzir a história dos Bancos Centrais de diferentes países será útil para este capítulo.

${ }^{80}$ Ver também Gould (2003, p. 552) sobre esse financiamento suplementar. Para a discussão sobre esses argumentos, ver a subseção 3.2.3, abaixo, neste capítulo.
} 
De outro lado, Vreeland também argumenta que algumas vezes os próprios governos nacionais podem querer assinar um acordo com o FMI. Nesse caso, o autor apresenta algumas hipóteses para defender esse argumento:

Algumas vezes os governos realmente querem que condições de política específicas do FMI sejam impostas sobre eles. Existem várias histórias políticas para compreender a razão pela qual governos desejariam a imposição de condições, como a história do bode expiatório, na qual governos buscam antecipar a culpa pela má performance econômica e a necessidade de reformas pelo FMI, bem como a história de sinalização, na qual o governo usa o FMI para amarrar suas mãos com o intuito de enviar um sinal de credibilidade do seu comprometimento com a reforma econômica para investidores e credores. A história política mais teorizada, contudo, baseada tanto em provas anedóticas como sistemáticas, é a história de "fazer pender a balança”, segundo a qual governos usam a pressão externa do FMI para pressionar por políticas impopulares que o governo realmente quer que sejam implementadas. (VREELAND, 2004, pp. 5-6, tradução nossa $)^{81}$

A passagem sugere que algumas vezes é o próprio governo de um país que deseja fazer uso de um empréstimo com o FMI para avançar reformas impopulares. Isso pode acontecer tanto no argumento da sinalização, explicado acima, mas principalmente por meio do mecanismo da alavancagem dos esforços do governo contra eventuais opositores. Ou seja, a pressão exercida pelo FMI é o motivo pelo qual o governo consegue pressionar pela aprovação de uma legislação ou de uma reforma que seja de seu interesse, mas que não tenham amplo apoio popular ou político.

Finalmente, a terceira ideia que inspirou a pesquisa apresentada neste capítulo é a de que a noção de credibilidade passou a guiar a gestão das políticas macroeconômicas do país a partir da década de 1990 (PAULANI, 2008). A noção de credibilidade expressa que, a partir da maior inserção da estrutura produtiva e financeira

\footnotetext{
${ }^{81}$ No original: "Sometimes governments actually want specific IMF policy conditions to be imposed on them. There are various political stories as to why governments would want conditions imposed, such as the scapegoat story, where governments seek to blame anticipated poor economic performance and needed reforms on the IMF, and the signaling story, where the government uses the IMF to tie its hands to send a credible signal of its commitment to economic reform to investors and creditors. The most theorized political story, however, and the one most supported by both anecdotal and systematic evidence is a "tipping the balance" story, where governments use the outside pressure of the IMF to push through unpopular policies that the government actually wants to implement."
} 
do país nos fluxos internacionais de capital, e com a escolha explícita do governo de interpretar essa inserção como um dos principais meios de promoção do desenvolvimento econômico (FRANCO, [1996], 1998), as políticas macroeconômicas deveriam passar a se guiar pelos parâmetros amplamente aceitos pela comunidade de investidores internacionais. No caso específico da política fiscal, esse argumento foi explorado também no capítulo 1. Em síntese, a ideia é a de que tal mudança no paradigma de gestão macroeconômica impactaria as dinâmicas de reforma do regime jurídico de qualquer política macroeconômica, inclusive da política fiscal.

A partir dessas três ideias e com o objetivo de analisar variáveis que podem explicar a aprovação do novo regime jurídico da política fiscal no Brasil, o capítulo está dividido da seguinte maneira: a primeira parte faz uma revisão de literatura sobre os elementos domésticos que resultaram na aprovação da Lei de Responsabilidade Fiscal (seção 3.1.); a segunda parte apresenta os quatro vetores de influências internacionais mencionadas que interferiram nessa aprovação (seção 3.2.); a última seção argumenta como uma análise conjunta de elementos domésticos e internacionais é essencial para compreender a regulação de aspectos fundamentais da gestão macroeconômica da sociedade em um contexto de globalização econômica (seção 3.3.), o que deve também ser feito no estudo da implementação do regime, como será visto no próximo capítulo.

\subsection{A centralidade de fatores domésticos na aprovação do regime}

Ao submeter o projeto da Lei de Responsabilidade Fiscal ao Presidente Fernando Henrique Cardoso, que o encaminhou ao Congresso Nacional, os ministros Pedro Malan (Ministro da Fazenda), Pedro Parente (do Orçamento e Gestão) e Waldeck Ornelas (Previdência e Assistência Social) declararam:

a aprovação de uma norma que estabelece princípios norteadores da gestão fiscal responsável, que fixa limites para o endividamento público e para a expansão de despesas continuadas, e que institui mecanismos prévios e necessários para assegurar o cumprimento de metas fiscais a serem atingidas pelas três esferas de governo, é a condição necessária e suficiente para a consolidação de um novo regime fiscal no País, compatível com a estabilidade de preços e o desenvolvimento sustentável (DCD, 1999, p. 15154, grifo nosso). 
Em outras palavras, na visão dos membros do governo federal que apoiavam a aprovação da Lei de Responsabilidade Fiscal, esta seria "a condição necessária e suficiente" para uma mudança significativa na gestão da política fiscal no país.

A literatura econômica tende a concordar com a afirmação encontrada na exposição de motivos do projeto de lei. A década de 1990 é geralmente apresentada como o período no qual a preocupação central com a política fiscal deixou de ser a manipulação da demanda agregada e passou a se concentrar em questões de sustentabilidade da dívida pública. ${ }^{82}$ Este seria o objetivo econômico que conduziria a consolidação de um novo regime jurídico para a política fiscal naquela década.

Como discutido no capítulo 1 , a transição de uma política físcal focada na manipulação da demanda agregada para uma política fiscal com foco na sustentabilidade da dívida pública deve ser interpretada no contexto teórico de questionamento das próprias conclusões e propostas keynesianas. A Lei de Responsabilidade Fiscal, para o bem ou para o mal, a depender da posição teórica do economista que analisa a mudança, é sempre considerada uma das peças centrais nesse processo.

Para citar dois exemplos que demonstram como a década de 1990 é geralmente interpretada como um momento de transição da política fiscal, é possível reproduzir as seguintes passagens de Lopreato e Tavares, respectivamente:

A estabilização e a integração ao mercado internacional colocaram questões de natureza diversa e levaram à construção de um novo regime fiscal, marcado, no primeiro momento, pela renegociação das dívidas estaduais, a reforma da previdência e as privatizações. O processo avançou em decorrência da crise de 1999, quando foi preciso alterar o regime de política econômica com o objetivo de recuperar a confiança arranhada pelo colapso do regime cambial. O enrijecimento da política fiscal teve como meta resgatar as contas públicas e demonstrar o comprometimento com a sustentabilidade da dívida pública. [...] A condução da política fiscal atrelou-se a regras e normas rígidas de cumprimento das metas programadas. [...] A aprovação da

\footnotetext{
${ }^{82}$ Nesse sentido, Lopreato (2002, 2004, 2006), Guardia e Goldfajn (2003), Giambiagi (2004, 2008). Sicsú e Vidotto apresentam uma boa síntese: "Ao analisar os aspectos fiscais do modelo econômico brasileiro, é comum constatar que os agentes atuantes no mercado financeiro, assim como os gestores de política econômica dos governos Fernando Henrique Cardoso e Luiz Inácio Lula da Silva têm um pensamento comum: a importância absoluta atribuída à estabilização da relação entre o estoque da dívida do setor público e o nível do produto" (in SICSU, 2007, p. 111).
} 
Lei de Responsabilidade Fiscal (LRF) avançou no processo de consolidação fiscal e institucionalizou as regras de comportamento orçamentário, obrigando a geração de superávits primários, o comprometimento com os compromissos financeiros, restringindo o acesso a novos créditos e estabelecendo limites de endividamento (LOPREATO, 2007, pp.4-5 e 34-35)

Em que pese o consenso alcançado em 1994 sobre a importância das reformas e de um ajuste fiscal estrutural, os primeiros anos do Plano Real não foram pródigos em resultados fiscais. [...] A nossa cultura política-administrativa, até a aprovação da Lei de Responsabilidade Fiscal, era caracterizada pela falta de compromisso institucional em relação à dívida. Assim, quando um novo governador ou prefeito tomava posse, tomava também um avião para ir à Brasília queixar-se de que estava recebendo o Estado ou o Município em péssimas condições financeiras e dizer que a dívida encontrada não era ele que tinha feito e que, portanto, não iria pagar, a menos que o governo central o ajudasse. Da mesma forma, mencionava os problemas relativos a seus bancos, prometia não utilizá-los como seus antecessores, jurava respeito ao Banco Central e, depois, nada cumpria. [...] A Lei de Responsabilidade Fiscal tem ensinado a todos a noção de limite orçamentário, tem ensinado que o governo não fabrica dinheiro. (TAVARES, 2005, pp. 11, 15 e 26)

A relevância de colocar lado a lado as duas citações é que elas explicitam que, tanto para críticos como para defensores, a Lei de Responsabilidade Fiscal é uma peçachave na construção de um novo regime jurídico da política fiscal centrado em objetivos relacionados com a sustentabilidade da dívida pública. Francisco Lopreato é um dos principais críticos da política fiscal a partir da década de 1990. Como ele próprio explicita na conclusão do texto mencionado anteriormente: "o relativo sucesso em alcançar o objetivo principal, no entanto, não encobriu a lógica perversa do ajuste fiscal." Martus Tavares, por sua vez, foi Ministro do Planejamento no período entre 1999 e 2002, e um dos principais defensores da aprovação da Lei de Responsabilidade Fiscal. Apesar da controvérsia na análise sobre a gestão da política fiscal, ambos concordam com a ideia de que a década de 1990 e, em especial a aprovação da Lei de 
Responsabilidade Fiscal, representam uma mudança paradigmática na gestão da política fiscal no país.

Outras passagens da exposição de motivos do projeto da Lei de Responsabilidade Fiscal sugerem que o objetivo da reforma do regime jurídico era consolidar a agenda da sustentabilidade da dívida pública na gestão da política fiscal. A exposição de motivos afirmava, por exemplo: "Este projeto integra o conjunto de medidas do Programa de Estabilidade Fiscal [...] que tem como objetivo a drástica e veloz redução do déficit público e a estabilização do montante da dívida pública em relação ao Produto Interno Bruto da economia" (DCD, 1999, p. 15154). Ou ainda: "buscou-se [...] construir compromisso em favor de um regime fiscal capaz de assegurar o equilíbrio intertemporal das contas públicas” (DCD, 1999, p. 15155). Incluir como objetivo do projeto de lei a estabilização do montante da dívida pública em relação ao PIB e defender que o seu compromisso era com o equilíbrio intertemporal das contas públicas são elementos que apontam para o acerto dos economistas que diagnosticam a mudança na preocupação da política fiscal naquele período.

Como já afirmado desde o capítulo 1, esta pesquisa não tem como foco a discussão econômica entre keynesianos e não keynesianos a respeito da política físcal. $\mathrm{Na}$ verdade, tem-se como objetivo compreender o modo pelo qual determinados atores usam o direito para a consolidação de certo entendimento político-econômico sobre política fiscal em um contexto democrático - no caso, o brasileiro. É isso que permitirá explorar como o direito contribui para estabelecer certos limites e possibilidades da gestão macroeconômica em um Estado democrático.

Desse modo, para além da mudança nas ideias hegemônicas sobre política econômica constatada pela literatura econômica e expressa nas declarações públicas das autoridades, é essencial tentar compreender os processos políticos por meio dos quais a reforma do regime jurídico foi realizada. Trata-se de analisar como o governo federal aprovou um regime jurídico para a política fiscal que reduziu consideravelmente a discricionariedade de estados e municípios em uma democracia federativa, organizada em um sistema presidencial pluripartidário, com diversos atores com poder de veto. ${ }^{83}$

\footnotetext{
${ }^{83}$ Leite (2005) explicita a dificuldade de se responder a essa questão, em especial caso se considere que a aprovação da lei era contrária aos interesses de governadores. Ver também: Abrucio e Loureiro (2002); Loureiro (2001) e Tavares (2005).
} 
Abrucio e Asazu (2003) apresentam cinco fatores que explicariam a aprovação da Lei de Responsabilidade Fiscal nesse contexto e podem ser lidos como um sucinto argumento da literatura:

(i) O Plano Real foi um momento crítico (critical juncture) que alterou a distribuição de poder e recursos entre atores, fortalecendo o governo federal para perseguir a agenda do ajuste fiscal e estabelecendo as condições básicas para uma nova cultura fiscal;

(ii) As regras fiscais foram aprovadas de forma incremental, o que permitiu ao mesmo tempo um processo de aprendizado social (social learning) e dependência de caminho (path dependence), no qual cada reforma tornava o retorno ao status quo anterior mais difícil;

(iii) A burocracia participou ativamente da elaboração e da aprovação da Lei de Responsabilidade Fiscal;

(iv) A mídia apoiou a iniciativa;

(v) O Executivo utilizou todos os mecanismos institucionais à sua disposição para acelerar a aprovação da Lei de Responsabilidade Fiscal no Congresso.

Os pontos acima serão discutidos em maiores detalhes nos próximos parágrafos. O Plano Real transformou a dinâmica da arena política e representou a maior plataforma eleitoral de um dos candidatos presidenciais na eleição de 1994, Fernando Henrique Cardoso. ${ }^{84}$ Por conta de seu sucesso, o partido do presidente e os partidos aliados foram capazes de eleger a maioria do Congresso e número significativo de governadores nas eleições daquele ano. ${ }^{85}$

No plano econômico, o Plano Real reduziu drasticamente a taxa de inflação, diminuindo a arrecadação de receitas pelos governos em todas as esferas derivada do

\footnotetext{
${ }^{84}$ Além de Abrúcio e Asazu (2003), ver: Leite (2005, pp. 61-85), Tavares (2005) e Abrúcio e Loureiro, (2002, pp. 13-14).

${ }^{85}$ Cardoso saiu vitorioso já no primeiro turno das eleições de 1994 , com $54,28 \%$ dos votos válidos. A aliança entre PSDB, PFL, PTB e PMDB - desconsiderando o PPB, que se aliaria posteriormente representava para o Presidente 291 deputados federais, dentre os 513, 58 senadores, de um total de 81, e 18 governadores, de um total de 27 . No caso dos governadores, a importância dessa eleição era ainda maior, uma vez que o PSDB elegeu os governadores de São Paulo, Mário Covas, de Minas Gerais, Eduardo Azeredo e do Rio de Janeiro, Marcelo Alencar. Os dados estão disponíveis em: <http://www.tse.jus.br/eleicoes/eleicoes-anteriores/eleicoes-1994/resultado-das-eleicoes-1994> (último acesso em 21 de outubro de 2014).
} 
que os economistas chamam de imposto inflacionário. ${ }^{86} \mathrm{O}$ fim do imposto inflacionário impactou severamente as receitas dos estados, provocando uma subsequente crise nos bancos controlados pelos governos estaduais. ${ }^{87}$ Além disso, a política monetária de aumentar as taxas de juros para conter a inflação pela atração de investimentos internacionais provocou um significativo impacto no serviço da dívida pública.

Em síntese, os estados e governadores se viram política e materialmente enfraquecidos face à União e ao presidente. Os estados passaram a operar em déficit primário e operacional, requerendo à União uma nova reestruturação da dívida e novos refinanciamentos para cumprirem com suas obrigações. Ou seja, estados e governadores dependiam dos recursos da União.

Essa dependência fica evidente na leitura do voto $n^{\circ} 162 / 1995$ do Conselheiro Pedro Malan, no Conselho Monetário Nacional, que resultou na criação do Programa de Apoio à Reestruturação e ao Ajuste Fiscal dos Estados no contexto da Lei $\mathrm{n}^{\mathrm{o}}$ $8.727 / 1993$, que reestruturou dívidas estaduais ${ }^{88}$ :

Após manter no período de 1991 a meados de 1994 execução fiscal semelhante à obtida pelo Governo Central, conseguindo em alguns momentos resultados até mesmo superiores aos da União, as finanças estaduais apresentam agora comportamento oposto, apesar da conjuntura amplamente favorável das receitas fiscais compostas pelo ICMS e pelas Transferências da União. Trata-se de situação que urge reverter, já que a continuidade do combate à inflação requer equilíbrio fiscal não apenas do Governo Federal, mas de todo o setor público. Levando em conta a diversidade de situações dos diferentes estados, o programa proposto compreende medidas de ajuste fiscal e saneamento financeiro, bem como linhas de crédito condicionadas a essas medidas. Além disso, prevê-se a possibilidade de reestruturação das AROs, sob condições estritas e que permitam reduzir o déficit dos estados.

\footnotetext{
${ }^{86}$ Para uma discussão sobre imposto inflacionário, ver Cysne (1994, p. 121) que o define como: “a sistemática perda de poder aquisitivo da moeda, penalizando a população e beneficiando o Banco Central, decorrente do fato da moeda render juros nominais nulos e, em consequência, estar sistematicamente desprotegida contra a inflação".

${ }^{87}$ Ver Leite (2005, pp. 61-85) e Abrúcio e Loureiro (2002).

${ }^{88}$ Para a íntegra do voto, ver: <http://www.fazenda.gov.br/divulgacao/publicacoes/conselho-monetarionacional-cmn/cmn-no-162-95> (último acesso em 5 de outubro de 2014).
} 
Em síntese, em uma situação de crise fiscal, os estados recorreram mais uma vez ao governo federal, que exigiu diversas contrapartidas para conceder financiamentos. ${ }^{89}$ O Ministro da Fazenda apresentou medidas de ajuste fiscal, como redução da despesa de pessoal, redução do quadro de funcionários, privatização, concessão de serviços públicos e reforma patrimonial, para a abertura de novas linhas de crédito para estados. $^{90}$

O voto de Pedro Malan deu início a uma série de negociações entre governo federal e governos estaduais, o que resultou na aprovação da Lei nº 9.496/1997. Essa lei consolidou e refinanciou as dívidas estaduais e do Distrito Federal com a União (LEITE, 2005; ABRUCIO e ASAZU, 2003). Como explicado no capítulo anterior, essa lei é também peça-chave na reforma do regime jurídico para a política fiscal, uma vez que estabeleceu limites para a gestão fiscal de estados e determinou a privatização/liquidação de empresas e bancos públicos. O próximo capítulo explorará em detalhes os impactos de sua aprovação.

Além disso, Abrucio e Asazu ainda afirmam que os elevados índices de aprovação do Presidente em 1994 concederam-lhe legitimidade para tentar alterar o paradigma político da política fiscal. ${ }^{91}$ A agenda do ajuste fiscal e das contas públicas

\footnotetext{
${ }^{89}$ A renegociação das dívidas estaduais com o governo foi comum no final da década de 1980 e no início da década de 1990. Ver, entre outros, Mora (2002) e Lopreato (2002).

${ }^{90}$ Não é outra a razão pela qual o voto apresentado no CMN foi denominado, à época, de "FMI do Malan". Esse era o termo usado por governadores, de acordo com o relato de Lopreato (2002) e Kugelmas e Sola (1999).

91 Abrucio e Asazu se referem aqui aos conceitos de paradigma político e aprendizado social, apresentados por Peter Hall em seu artigo clássico de 1993. A discussão envolve a relação entre ideias e políticas. Para Hall, aprendizado social pode ser definido "como a tentativa deliberada de ajustar os objetivos ou técnicas da política pública em face de experiências prévias e informação nova." No original: "we can define social learning as a deliberate attempt to adjust the goals or techniques of policy in response to past experience and new information" (1993, p. 278). Por sua vez, um paradigma político deve ser interpretado como uma "estrutura de ideias e padrões que especificam não somente os objetivos da política pública e o tipo de instrumentos que podem ser usados para alcançá-los, mas também a própria natureza dos problemas que eles têm a intenção de resolver. Como um Gestalt, essa estrutura está incrustada na própria terminologia por meio da qual os políticos e burocratas (policymakers) comunicam a respeito do seu trabalho, e é influente precisamente porque grande parte dessa estrutura é tomada como pressuposta e é complicado analisá-la como um todo. Chamarei essa estrutura interpretativa de paradigma político". No original: "[policymakers customarily work within] a framework of ideas and standards that specifies not only the goals of policy and the kind of instruments that can be used to attain them, but also the very nature of the problems they are meant to be addressing. Like a Gestalt, this framework is embedded in the very terminology through which policymakers communicate about their work, and it is influential precisely because so much of it is taken for granted and unamenable to scrutiny as a whole. I am going to call this interpretive framework a policy paradigm" (1993, p. 279). Há toda uma literatura institucionalista que se desenvolveu a partir desses trabalhos de Hall para discutir mudanças políticas e institucionais a partir dessa estrutura interpretativa proposta pelo autor, mas não é necessário retomá-la aqui. Ver, por exemplo, o resumo da literatura por Cashore e Howlett (2009). Os autores analisam a literatura institucionalista sobre mudanças políticas, considerada ortodoxa e influenciada por Hall, a partir da diferenciação de fatores de natureza endógena ou exógena como variáveis para a explicação da mudança política.
} 
como o principal mecanismo para superar a crise econômica brasileira estava clara para Fernando Henrique Cardoso desde que ele era Ministro da Fazenda, ainda em 1993. Em um dos documentos do Programa de Ação Imediata, que fez parte dos programas do Plano Real, a assessoria de comunicação social do gabinete do então Ministro da Fazenda afirma:

a economia brasileira está sadia, mas o governo está enfermo. O diagnóstico sobre a causa fundamental da doença inflacionária já foi feito. É a desordem financeira e administrativa do setor público. [...]

Se o governo não consegue praticar uma política fiscal voltada para o futuro, o Banco Central, por seu lado, se vê impossibilitado de praticar uma política monetária ativa. A prescrição essencial também é conhecida. $\mathbf{O}$ governo precisa arrumar sua própria casa e pôr as contas em dia. (BRASIL, 1993, p. 1, grifo nosso)

Em outras palavras, desde 1993, Fernando Henrique Cardoso defendia a tese de que, para retirar o Brasil da crise econômica que enfrentava, era preciso promover um ajuste fiscal: "arrumar sua própria casa e pôr as contas em dia". Neste nível de análise, a literatura da ciência política está de acordo com o diagnóstico da literatura econômica, a respeito da mudança das ideias hegemônicas sobre o papel das políticas econômicas, em especial da necessidade de ajuste fiscal.

Contudo, Abrucio e Asazu ainda acrescentam outros elementos para argumentar que a agenda do ajuste teve um apoio mais generalizado que o mero consenso das elites políticas organizadas no Poder Executivo federal: (i) até partidos da oposição perseguiram a agenda de ajuste nos estados e municípios que governaram; (ii) a análise de seis jornais de grande circulação no período de discussão da Lei de Responsabilidade Fiscal no Congresso demonstra que, do total de 137 referências jornalísticas sobre a votação, somente 4 foram explicitamente contrárias à aprovação do projeto.

Por fim, os autores argumentam que o governo federal perseguiu um plano de reforma favorável ao ajuste fiscal que fortaleceu a burocracia do Executivo Federal ao longo do processo de ajuste, o que garantiu o seu apoio. Os papéis da Secretaria do Tesouro Nacional e do Ministério do Planejamento na negociação da reforma foram essenciais e tais órgãos tiveram suas competências alargadas por quase todas as novas regras. 
No caso específico de aprovação da Lei de Responsabilidade Fiscal, havia a pretensão de incluir o maior número possível de atores no processo de discussão e aprovação da legislação. Relata-se que foram realizadas diversas reuniões entre Ministérios e Secretarias, no plano federal, e entre Ministério do Planejamento e Secretarias estaduais de Finanças Públicas, no plano federativo, para discussão e negociação da Lei de Responsabilidade Fiscal. O projeto da Lei de Responsabilidade Fiscal foi ainda publicado em um sítio eletrônico do Ministério do Orçamento e Gestão, recebendo mais de 5.000 consultas (ABRUCIO E ASAZU, 2002; TAVARES, 2005; LEITE, 2005). ${ }^{92}$

Além de tudo, Abrucio e Asazu argumentam que as regras para a política fiscal produzidas anteriormente, como eram os casos das Leis Camata, da Emenda Constitucional sobre precatórios, da Lei de Renegociação das Dívidas Estaduais de 1997, entre outros, permitiram que as ferramentas e os objetivos previstos na Lei de Responsabilidade Fiscal fossem ajustados a experiências anteriores (2003, pp. 5-6).

Desse modo, os autores concluem que:

Todo este processo descrito até aqui, de medidas aprovadas, reações, avanços e novos posicionamentos dos atores, vai afetar a aprovação da Lei de Responsabilidade Fiscal e suas características normativas, estabelecendo, a cada alteração, uma nova "camada", que dificultava sobremaneira a volta ao estágio anterior. A LRF foi resultado, desse modo, de um processo de path dependence. (2003, p. 6).

Interpretar a aprovação da reforma do regime jurídico da política fiscal dessa perspectiva leva à conclusão de que a esfera internacional não teve qualquer importância na aprovação da Lei de Responsabilidade Fiscal no país. Quando influências internacionais são mencionadas, elas geralmente são marginais. A crise econômica da Rússia de 1998 costuma ser descrita como a pressão externa que demandou uma ação fiscal mais proativa do governo federal, o que teria acelerado a aprovação da Lei de Responsabilidade Fiscal. ${ }^{93}$ Contudo, este capítulo defende que,

\footnotetext{
92 Embora não tenha sido possível obter qualquer uma dessas consultas e do teor dos comentários apresentados. No dia 14 de fevereiro de 2014, por meio do Sistema Eletrônico do Serviço de Informação ao Cidadão (e-SIC), solicitei ao Banco Nacional de Desenvolvimento Econômico e Social, ao Ministério da Fazenda e ao Ministério do Planejamento, Orçamento e Gestão acesso aos referidos comentários e às atas das possíveis reuniões realizadas. As respostas fornecidas pelos órgãos, contudo, não permitiram acesso aos comentários apresentados. Para o relatório dos pedidos, ver os anexos desta dissertação.

${ }^{93}$ Ver Abrucio e Loureiro (2002, p. 79) e Abrucio e Asazu (2003, p. 9).
} 
sem recurso a uma perspectiva internacional, é impossível descrever corretamente o contexto de aprovação da Lei de Responsabilidade Fiscal no país.

\subsection{Vetores de influências internacionais na reforma do regime jurídico da política fiscal}

\subsubsection{Crise dos países emergentes}

O primeiro vetor de influência internacional reconhecido pela literatura, embora nunca enfatizado, é o de que o contexto internacional de crise econômica de países emergentes foi um dos principais motivos para o governo federal pressionar pela aprovação de um novo regime fiscal como um todo e, em particular, pela consolidação de um novo regime jurídico da política fiscal. A crise dos Tigres Asiáticos de 1997 e a crise da Rússia de 1998 teriam demonstrado para as autoridades brasileiras a fragilidade das condições das economias emergentes e a necessidade do Brasil se diferenciar perante outras economias para atrair o fluxo do capital internacional.

Dois meses após a moratória russa, no dia 28 de outubro de 1998, o governo federal anunciou o Programa de Estabilidade Fiscal (PEF) que representava "passo decisivo na consolidação do processo de redefinição do modelo econômico brasileiro". Tratava-se, segundo o próprio governo, de definir a "mudança do regime fiscal do País". $\mathrm{O}$ objetivo do $\mathrm{PEF}$, em linha com a mudança de paradigma político apresentado na seção anterior, era claro: "O governo federal apresenta à sociedade brasileira seu Programa de Estabilidade Fiscal, fundado em uma premissa básica: o Estado não pode mais viver além de seus limites, gastando mais do que arrecada”. Dentre as medidas que seriam adotadas, a Lei de Responsabilidade Fiscal ganhava proeminência, pois constituiria "instrumento importante para o êxito deste Programa de Estabilidade Fiscal, ao criar mecanismos institucionais que tornem permanentes os ganhos fiscais constantes do Programa" (BRASIL, 1998).

Para os fins desta seção, o que importa ressaltar é a influência internacional na aprovação do novo regime jurídico da política fiscal. E isso fica evidente no próprio documento:

As sucessivas crises no mercado internacional - desde a ruptura do modelo do sudeste asiático até a recente moratória russa engendraram um movimento de preferência acentuada por ativos mais líquidos e de menor risco, provocando severa contração do crédito global, sobretudo (mas não exclusivamente) para os mercados 
emergentes. Não se espera que essa tendência configure um estado permanente de escassez de crédito generalizada. No entanto, é certo que os fluxos mundiais de capitais serão muito mais seletivos, sendo fundamental, para minimizar o custo do ajuste da economia brasileira, reforçar os elementos que permitam a diferenciação do País em relação a outros países emergentes. Acresce que já estamos no quinto ano do processo de estabilização monetária, sendo ainda necessário construir alicerces firmes para sua consolidação. Neste sentido, quer por necessidades associadas ao novo ambiente internacional, quer por uma exigência inescapável da presente situação da economia brasileira, afigura-se como indispensável um rápido ajuste das contas públicas. (BRASIL, 1998, grifo nosso)

Portanto, tanto o ambiente internacional como a situação doméstica foram ressaltados como relevantes pelas autoridades federais no momento de apresentação do programa econômico que daria "um passo decisivo na redefinição do modelo econômico brasileiro". A influência do ambiente internacional como um contexto que fortaleceu os esforços para promoção de um ajuste fiscal e da inclusão na pauta política da ideia de reforma do regime jurídico da política fiscal é ressaltada pelas próprias autoridades públicas. A análise dos documentos que criaram o Programa de Estabilidade Fiscal demonstra igualmente como a questão da credibilidade se tornou central na agenda política brasileira.

A passagem transcrita acima sugere ainda que, da perspectiva dos atores do Executivo, as medidas previstas pelo Programa seriam essenciais para que o Brasil se diferenciasse das demais economias emergentes. Dentre essas medidas, estava a aprovação de uma Lei de Responsabilidade Fiscal.

No dia 8 de outubro de 1998, vinte dias antes do anúncio do Programa de Estabilidade Fiscal e três dias depois da reeleição de Fernando Henrique Cardoso para presidente, o FMI e o governo brasileiro publicaram uma nota conjunta anunciando que discussões entre as autoridades nacionais e o Fundo estavam ocorrendo. Segundo o informativo, o objetivo das discussões era o de "se alcançar um acordo em um programa detalhado de políticas fiscais e outras políticas macroeconômicas e estruturais que poderiam ser apoiadas financeiramente pelo FMI e por outros membros da comunidade 
internacional"94. Nota-se como uma das variáveis apontadas por Maxfield se aplica ao caso brasileiro: segundo a autora, a sinalização dos governos a investidores internacionais tenderia a ocorrer com mais frequência quanto mais os políticos estivessem seguros da continuidade em seus cargos políticos. Não há exemplo melhor do que o anúncio conjunto de um "programa detalhado de políticas fiscais", entre o FMI e o governo brasileiro, somente três dias após a reeleição do Presidente para mais quatro anos de mandato presidencial.

As negociações com o FMI continuariam nos meses seguintes. No dia 13 de novembro de 1998, quinze dias após a apresentação do Programa de Estabilidade Fiscal e um pouco mais de um mês após a publicação da nota conjunta, Pedro Malan e Gustavo Franco, então Presidente do Banco Central do Brasil, assinaram uma carta de intenções endereçada ao FMI descrevendo políticas brasileiras que "promoveriam crescimento sustentável e equilibrado no longo prazo". 95 Na realidade, o documento reproduzia em grande parte o Programa de Estabilidade Fiscal para, ao fim, requerer auxílio da comunidade internacional, em um contexto de restrição de crédito. O valor do empréstimo requerido ao FMI pelo acordo stand-by era de US\$ 18 bilhões.

$\mathrm{Na}$ linha do que foi discutido na apresentação do PEF, entre as medidas descritas pelas autoridades brasileiras no anexo Memorando de Políticas Econômicas, prometiam-se:

mudanças fundamentais na administração das finanças públicas. Um elemento chave nesses esforços é a nova Lei de Responsabilidade Fiscal, que o governo submeterá ao Congresso até dezembro. A nova lei estabelecerá uma estrutura geral para guiar o planejamento e a execução orçamentária. Com o objetivo de assegurar solvência fiscal, a nova lei irá, inter alia, estabelecer critérios prudenciais para o endividamento público; providenciar regras rígidas para o controle dos gastos públicos; estabelecer regras para o limite de déficits

\footnotetext{
94 Apenas a título de curiosidade, é importante notar que o governo brasileiro não divulga tais informações. Elas podem ser encontradas no sítio eletrônico do Fundo Monetário Internacional: <http://www.imf.org/external/np/sec/nb/1998/nb9836a.htm> (último acesso em 16 de junho de 2014). No original: "Discussions will continue in the days ahead, with the aim of reaching agreement soon on a detailed program of fiscal and other macroeconomic and structural policies, that could be supported financially by the IMF and other members of the international community."

${ }^{95}$ Vale ressaltar, mais uma vez, que a literatura sobre FMI sugere que "é comum alegar que a Carta de Intenções é com frequência inteiramente elaborada pelo pessoal do FMI" (Vreeland, 2007, p. 32). O texto da Carta de Intenções assinada pelo governo brasileiro está disponível em: <http://www.imf.org/external/np/loi/111398.htm> (último acesso em 16 de outubro de 2014). No original: "The Government believes that these policies will promote sustainable and equitable long term growth of output".
} 
orçamentários e proibir qualquer futuro refinanciamento pelo governo federal de dívidas estaduais e municipais. Além disso, a lei incluirá mecanismos disciplinares na eventualidade dessas metas e procedimentos serem desrespeitados. ${ }^{96}$

Mais uma vez, não só o governo brasileiro anunciou o interesse em consolidar um novo regime jurídico para a política fiscal, como prometeu internacionalmente que o faria, anunciando a alteração como uma das reformas estruturais negociadas com o FMI para recebimento do crédito de US\$ 18 bilhões.

O pedido de empréstimo foi aprovado pelo Conselho de Diretores do FMI em dezembro de $1998 .^{97}$ A Lei de Responsabilidade Fiscal fez parte de todos os documentos das quatro revisões oficiais do acordo stand-by entre Brasil e FMI até a sua promulgação em maio de 2000. O acordo inicial, representado pelo envio da Carta de Intenções em novembro de 1998 e pela aprovação do pedido pelo Conselho de Diretores do FMI em dezembro do mesmo ano, foi revisado em março (primeira e segunda revisões), julho (terceira revisão) e novembro (quarta revisão) de 1999. Na quinta revisão, em maio de 2000, a Lei de Responsabilidade Fiscal já tinha sido aprovada e sancionada. O Conselho de Diretores, ao aprovar essa revisão, enalteceu a aprovação da lei. ${ }^{98}$

\footnotetext{
${ }^{96}$ O texto da Carta de Intenções está disponível em: 〈http://www.imf.org/external/np/loi/111398.htm> (último acesso em 16 de outubro de 2014). No original: "The federal government plans to make fundamental changes to the management of its finances. A key element in its efforts will be the new Fiscal Responsibility Act, which the government will submit to Congress by December. The new law will set up a general framework to guide budgetary planning and execution. With a view to ensuring fiscal solvency, the law will, inter alia, establish prudential criteria for public indebtedness; provide strict rules for the control of public expenditures; establish standing rules to limit budget deficits, and prohibit any further refinancing by the federal government of state and municipal debt. In addition to these precepts, the law will include disciplinary mechanisms in the event that its targets and procedures are not observed".

${ }^{97}$ No anúncio da aprovação do projeto, o FMI reforçou as promessas realizadas pelo governo federal brasileiro, incluindo uma seção sobre "Reformas estruturais", na qual manifestou: "o governo pretende introduzir uma série de reformas no processo orçamentário com o objetivo de fortalecer a disciplina orçamentária [...] Uma peça-chave nesse esforço será o Ato de Responsabilidade Fiscal, que será submetido ao Congresso em pouco tempo" (no original: "the government intends to introduce a number of reforms in the budget process aimed at strengthening budget discipline [...]. A centerpiece of this effort will be the Fiscal Responsibility Act, which will be submitted to Congress shortly"). O texto está disponível em: <https://www.imf.org/external/np/sec/pr/1998/pr9859.htm> (último acesso em 6 de outubro de 2014).

${ }^{98} \mathrm{Na}$ nota publicada amplamente e disponível no sítio eletrônico do FMI sobre a aprovação da Quinta Revisão: "Na área de reformas estruturais, os Diretores saudaram a promulgação recente da Lei de Responsabilidade Fiscal, que fortalece a estrutura institucional para a disciplina fiscal sustentável em todos os níveis de governo". "In the structural reform area, Directors welcomed the recent enactment of the Fiscal Responsibility Law, which strengthens the institutional framework for sustained fiscal discipline at all levels of government.". A nota está disponível em: $<$ https://www.imf.org/external/np/sec/nb/2000/nb0033.htm> (último acesso em 6 de outubro de 2014).
} 
Nesse contexto, é interessante analisar o que inspirou as autoridades brasileiras e o FMI a verem na aprovação da Lei de Responsabilidade Fiscal um elemento de diferenciação da economia brasileira em relação a outras economias emergentes.

\subsubsection{Experiências internacionais com regras fiscais como padrão de excelência}

Uma primeira resposta à questão apresentada no fim do tópico anterior pode ser esboçada a partir da ideia de que experiências internacionais anteriores com regras fiscais representaram um padrão de excelência para a elaboração da Lei de Responsabilidade Fiscal. ${ }^{99}$ A própria terminologia da Lei já aponta para a real influência de experiências internacionais prévias, uma vez que o Brasil batizou a lei com título semelhante àquele da lei aprovada na Nova Zelândia no começo da década de 1990: Fiscal Responsability Act.

Essa influência é confirmada pelos burocratas que participaram da elaboração do projeto de lei. Em artigo apresentado e discutido em janeiro de 1999, no Seminário de Finanças Públicas promovido pela Comissão Econômica das Nações Unidas para a América Latina - CEPAL, antes mesmo do envio do projeto para o Congresso, os técnicos do governo federal afirmaram:

Os princípios de responsabilidade fiscal sugeridos na Lei de Responsabilidade Fiscal seguem, em larga medida, aqueles adotados pela Nova Zelândia e representam um caminho para restabelecer a consistência e estabilizar a relação entre dívida pública/PIB (Afonso et al, 2000, p. 216). ${ }^{100}$

Sobretudo, a mais clara evidência da influência de experiências internacionais com regras fiscais pode ser vista na análise do projeto da lei. No primeiro texto publicado para consulta pública, em dezembro de 1998, dos 111 artigos, 23 foram

\footnotetext{
${ }^{99}$ A ideia de um padrão de excelência é mencionada também por Leite (2005, p. 91).

100 No original: "Los principios de responsabilidad sugeridos en la LRF siguen, en su mayoría, los adoptados por Nueva Zelanda y representan el camino para restablecer la consistencia y estabilizar la relación deuda/PIB." Em outra passagem do texto, os autores afirmam: "A exemplo da experiência da União Européia, optou-se por introduzir na Lei de Responsabilidade Fiscal dispositivos de flexibilização das regras" (Afonso et al., 2000, p. 217, tradução nossa). No original: "a ejemplo de la experiencia de la UME, se optó por colocar em la LRF dispositivos de flexibilización de las reglas".
} 
explicitamente baseados em experiências internacionais. ${ }^{101} \mathrm{O}$ projeto reconhecia a centralidade do modelo neozelandês para a criação da legislação brasileira, mas também admitia a influência do Código de Transparência Fiscal do FMI, do Budget Enforcement Act dos Estados Unidos e do Tratado de Maastrich.

Embora o Congresso tenha alterado substancialmente o projeto, as principais regras e princípios baseados nas experiências internacionais, a exemplo da previsão de metas trienais para a política fiscal e de relatórios sobre seu cumprimento, permaneceram no texto da lei, como se percebe pela análise das regras apresentadas no capítulo anterior. Contudo, as duas influências apresentadas até agora não constituem as principais formas de interação entre elementos domésticos e internacionais na aprovação do novo regime jurídico da política fiscal.

\subsubsection{A Lei de Responsabilidade Fiscal como uma reforma estrutural: o efeito de sinalização}

Na quarta revisão do acordo com o FMI, em novembro de 1999, o governo federal prometeu promulgar a Lei de Responsabilidade Fiscal como uma das reformas estruturais até o fim de fevereiro de $2000 .{ }^{102}$ Até aquela revisão, embora a lei fosse sempre mencionada, não havia prazo para sua aprovação. O prazo apresentado na quarta revisão não foi respeitado, mas a lei foi sancionada com somente três meses de atraso, em 4 de maio de 2000.

Nesse contexto, é importante analisar se a aprovação da Lei de Responsabilidade Fiscal poderia ter sido uma imposição do organismo multilateral ao Brasil. Afinal, qual governo nacional aprovaria um regime jurídico que vinculasse futuros governos à austeridade - ou que pelo menos impossibilitasse várias opções de política fiscal? Como um governo se comprometeria com a aprovação de tais regras em face da provável oposição de estados e municípios, muitos deles governados por aliados?

\footnotetext{
101 A experiência da Nova Zelândia explicitamente influenciou 10 artigos; a experiência europeia, 5; a experiência estadunidense, 6; e o Código do FMI, 4 - alguns artigos se basearam em mais de uma experiência internacional ao mesmo tempo. O projeto de lei pode ser encontrado em: <http://www.bndes.gov.br/SiteBNDES/export/sites/default/bndes_pt/Galerias/Arquivos/bf_bancos/APLC QCOM.pdf> (último acesso em 16 de outubro de 2014).

${ }^{102}$ Em novembro de 1999, o projeto ainda estava na Comissão Especial da Câmara dos Deputados e nem o parecer do relator, o deputado federal Pedro Novais, havia sido apresentado. Após a aprovação na Câmara, o projeto ainda teria que ser avaliado pelo Senado e, em caso de eventuais alterações, teria que ser rediscutido na Câmara. Ver tramitação do PLP 18/1999, no sítio eletrônico da Câmara dos Deputados: $<$ http://www.camara.gov.br/proposicoesWeb/fichadetramitacao?idProposicao=38154> (último acesso em 16 de outubro de 2014).
} 
$\mathrm{O}$ argumento da imposição era um dos argumentos dos opositores da lei. As falas do deputado federal João Passarela (líder do PT na Câmara), no debate na Câmara dos Deputados, defendendo a rejeição do projeto de lei são claras: "essa lei tem uma origem: é uma imposição do Fundo Monetário Internacional ao país”. O deputado ainda argumentava: “Ao impor essa lei à Nação, inserindo-a no acordo e no ajuste, o FMI tem um único objetivo: que o governo brasileiro diga aos credores internacionais que, independentemente do que acontecer no País, os interesses, os compromissos com os juros e com a dívida serão honrados" (DCD, 26 de janeiro de 2000, p. 3664). ${ }^{103}$

De outro lado, a literatura sobre o tema sugere que a imposição não existiu porque "o projeto foi extremamente criticado pelos técnicos do Fundo" (LEITE, 2005, pp. 88-89). Outros elementos sugeririam que a aprovação da Lei de Responsabilidade Fiscal não foi uma imposição do órgão multilateral: o grupo de discussão do projeto no Poder Executivo foi formado em 1997, antes de qualquer discussão sobre o eventual acordo com o FMI; o governo lutou para incluir um prazo final para a proposta de um Código de Finanças Públicas em uma emenda constitucional de junho de $1998 .{ }^{104}$ Ainda, todas as variáveis domésticas mencionadas na seção 3.1., que enfatizam fatores internos que resultaram em sua aprovação, são levadas em consideração para afirmar que a aprovação da lei não foi uma imposição (LEITE, 2005, pp. 88-90).

Contudo, entre imposição e total falta de influência há uma ampla gama de opções. O fato de que a Lei de Responsabilidade Fiscal esteve sempre presente dos documentos oficiais sugere que o organismo multilateral, em particular, e a esfera internacional, como um todo, tiveram outros papéis na aprovação da lei para além de terem feito parte do contexto geral de crise econômica dos países emergentes e de terem fornecido um padrão de excelência para a lei.

Esta dissertação argumenta que a terceira influência internacional na aprovação da Lei de Responsabilidade Fiscal foi a importância da lei como sinalização do governo federal de que agiria conforme os interesses de eventuais investidores e do discurso prevalecente nas esferas internacionais sobre política fiscal, que demandava uma maior preocupação com a sustentabilidade da dívida pública. Nesse sentido, a inclusão da

\footnotetext{
${ }^{103}$ Ver, no mesmo sentido, as manifestações dos Deputados Federais Agnelo Queiroz (DCD, 20 de janeiro de 2000, p. 2675) e Sérgio Miranda (DCD, 20 de janeiro de 2000 e 26 de janeiro de 2000).

${ }^{104} \mathrm{O}$ artigo 30 da Emenda Constitucional $\mathrm{n}^{\circ} 19$ - a emenda da Reforma do Estado - aprovada em 4 de junho de 1988, estabelece: "o projeto de lei complementar a que se refere o art. 163 da Constituição Federal será apresentado pelo Poder Executivo ao Congresso Nacional no prazo máximo de cento e oitenta dias da promulgação desta Emenda". Nota-se que o termo "Lei de Responsabilidade Fiscal", contudo, não tinha sido adotado ainda nesse momento.
} 
aprovação da lei como parte das reformas estruturais previstas no acordo com o FMI foi essencial. O acordo com o FMI funcionaria como símbolo de que o país se adequaria a um determinado discurso internacional sobre práticas físcais e gestão das dívidas públicas, em consonância aos interesses dos investidores. ${ }^{105}$

Para defender que o efeito de sinalização estava acontecendo com a inclusão da Lei de Responsabilidade Fiscal no acordo com o FMI, esta seção apresenta três diferentes argumentos: (i) o FMI simbolizava uma espécie de garantia de que o Brasil agiria conforme os interesses e discursos internacionais ao aprovar um novo regime jurídico da política fiscal; (ii) existia um discurso internacional sobre práticas fiscais às quais o Brasil poderia se adequar; (iii) a aprovação da Lei de Responsabilidade Fiscal poderia ser interpretada por investidores internacionais como um sinal de que o governo brasileiro atuaria de fato conforme seus interesses. Nota-se que esses fatores não abrangem a análise sobre a existência de um aumento de investimentos internacionais no país logo após a aprovação da lei. Isso porque a questão que se pretende responder é se a aprovação da Lei de Responsabilidade Fiscal sinalizava a tentativa do governo brasileiro de se adequar ao discurso hegemônico internacionalmente sobre práticas fiscais e aos eventuais interesses de investidores. E se a inclusão da aprovação da lei no acordo com o FMI fazia parte desse processo de sinalização.

Quando Pedro Malan anunciou o acordo entre Brasil e FMI para jornalistas brasileiros, em novembro de 1998, ele explicou que o empréstimo do FMI era somente parte de um apoio ainda maior. O acordo, explicou o ministro da Fazenda, abriria a possibilidade de financiamento de outras instituições multilaterais e países. A literatura sobre FMI mencionada no início deste capítulo explica a importância desses empréstimos suplementares:

o tamanho de um empréstimo do FMI geralmente não é suficiente para um país que enfrenta uma crise econômica no balanço de pagamentos. Assim, "financiamentos suplementares" de várias fontes são comuns. Além de providenciar um empréstimo, o FMI negocia com outras fontes de financiamento internacional - tais como governos de países desenvolvidos, organizações multilaterais, e instituições privadas de crédito - empréstimos "suplementares". Esses

\footnotetext{
105 O efeito de sinalização em geral está presente nas discussões sobre o impacto da assinatura de um acordo stand-by com o FMI. Ver Vreeland (2007, p. 63) e Mazzuoli (2005, p. 220). No caso desta dissertação, não se avalia o acordo como um todo, mas a específica discussão a respeito da aprovação da Lei de Responsabilidade Fiscal.
} 
"credores suplementares" estão dispostos a auxiliarem o FMI no socorro de países em desenvolvimento porque o FMI promete monitorar e garantir condições econômicas para melhorar as condições das balanças de pagamentos dos países, o que facilita suas próprias transações financeiras e torna o pagamento do empréstimo mais provável (GOULD, 2003, p. 552, tradução nossa). ${ }^{106}$

Ou seja, um empréstimo do FMI geralmente não é suficiente para socorrer um país em crise. Na realidade, o FMI se junta ao país para angariar recursos de outras fontes. A partir de estudos de casos e análise documental, Erica Gould afirma que há influência desses credores suplementares no desenho das condicionalidades dos acordos do Fundo (2003, p. 552). No caso brasileiro de 1998, mais da metade do apoio financeiro veio de outras instituições e países, como o Banco Mundial, o Banco Interamericano de Desenvolvimento, União Europeia, Estados Unidos, Canadá e Japão.

Como uma das "partes centrais do acordo" entre Brasil e FMI era a aprovação da Lei de Responsabilidade Fiscal, esse é um forte indício de que o efeito de sinalização estava presente quando o Brasil se comprometeu a aprovar a lei perante o FMI. Provavelmente a aprovação da Lei de Responsabilidade Fiscal era vista como elemento importante pelos demais credores para a credibilidade da política fiscal brasileira e para a sustentabilidade da dívida pública.

Outros elementos também corroboram a hipótese de que a aprovação da Lei de Responsabilidade Fiscal era parte de um efeito de sinalização do governo brasileiro para investidores internacionais: (i) em quase todos os pronunciamentos públicos do FMI e seus diretores sobre o acordo, a aprovação da Lei de Responsabilidade Fiscal como uma reforma estrutural era mencionada e ressaltada ${ }^{107}$; (ii) após sua aprovação, a lei foi

\footnotetext{
${ }^{106} \mathrm{Na}$ versão original: "the size of an IMF loan is often not sufficient for a country in economic crisis to balance its payments. "Supplemental financing" from various sources is thus commonplace. In addition to providing a loan, the IMF negotiates with other sources of international finance - such as the government of developed countries, multilateral organizations, and private lending institutions - to provide "supplemental" loans. These "supplemental financiers" are willing to assist the IMF in bailing out developing countries because the IMF promises to monitor and enforce economic conditions to improve countries' balance of payments situations, which in turn facilitates their own financial transactions and makes loan repayment more likely". Ver também Vreeland (2007).

107 Ver, entre outras, as notas emitidas pelo organismo multilateral e disponíveis em: <http://www.imf.org/external/np/sec/nb/2000/nb00108.htm>;

$<\mathrm{http}: / /$ www.imf.org/external/np/sec/nb/2001/nb0130.htm>;

<http://www.imf.org/external/np/sec/nb/2002/nb0203.htm> (último acesso em 6 de outubro).
} 
amplamente elogiada $^{108}$; (iii) em futuros acordos entre Brasil e FMI, a Lei de Responsabilidade Fiscal era mencionada como essencial para garantir a sustentabilidade da dívida pública brasileira.

A aprovação de leis de responsabilidade fiscal também era recomendada por outros organismos multilaterais. Por exemplo, um relatório da OCDE de 1997, com o título de "Modern Budgeting", apresentava um resumo das reformas na administração do setor público na Austrália, França, Nova Zelândia, Suécia e Reino Unido na década de 1990 e concluía, a partir da análise da Lei de Responsabilidade Fiscal neozelandesa, que outros países da OCDE deveriam promover reformas semelhantes (OCDE, 1997, p. 98). ${ }^{109}$

No mesmo sentido, o Banco Mundial aprovou uma linha de crédito específica para o Brasil em 2000, dois meses antes da aprovação da Lei de Responsabilidade Fiscal, no valor de US\$ 506 milhões, para o programa "Empréstimo para a Reforma Fiscal e Administrativa". Nesta linha de crédito, o Banco ficaria responsável por dar suporte técnico para a realização de reformas que tivessem como objetivo "a implementação de leis que o Congresso tinha aprovado" (BANCO MUNDIAL, 2001, p. 3). O Banco apoiaria a implementação de uma política pública e de três leis específicas: (i) o Programa de Estabilidade Fiscal; (ii) a Lei de reestruturação das dívidas estaduais e seus acordos específicos; (iii) a emenda constitucional da reforma administrativa que permitiu a dispensa de servidores públicos nos casos em que houvesse excesso de gasto com pessoal; (iv) e a Lei de Responsabilidade Fiscal (2001, p. 8). ${ }^{110}$

Ainda no âmbito do Banco Mundial, o Relatório do Banco Mundial para o biênio 1999/2000, publicado em agosto de 1999, trazia uma seção especial sobre o Brasil. O relatório argumentava que, em face da descentralização formal estimulada pela Constituição Federal de 1988, as reformas a serem promovidas no país deveriam fortalecer as restrições orçamentárias às operações de crédito dos entes subnacionais e "a distribuição de poder entre presidente e o Legislativo deveria ser reexaminada. [...]

\footnotetext{
${ }^{108}$ Como no Relatório sobre Observância dos Padrões e regras - Transparência Fiscal, no original Report on Observance of Standards and Codes - Fiscal Transparency Mode, publicado pelo FMI em $2001 \mathrm{e}$ disponível em: <https://www.imf.org/external/pubs/ft/scr/2001/cr01217.pdf> (último acesso em 6 de outubro de 2014).

${ }^{109} \mathrm{O}$ relatório está disponível em: <http://www.oecd.org/gov/budgeting/36233618.pdf> (último acesso em 30 de setembro de 2014).

${ }^{110} \mathrm{O}$ relatório pode ser encontrado em:

$<$ http://www-

wds.worldbank.org/external/default/WDSContentServer/WDSP/IB/2002/02/09/000094946_02012504075 647/Rendered/PDF/multi0page.pdf> (último acesso em 6 de outubro de 2014)
} 
Para dificultar que grupos de interesse dos estados conspirem contra o todo, a Presidência precisa ser fortalecida" (BANCO MUNDIAL, 1999, p. 166) ${ }^{111}$.

O efeito de sinalização também deve ser interpretado a partir da perspectiva de que a década de 1990 foi fortemente marcada pela hegemonia do discurso sobre sustentabilidade da dívida pública nas discussões sobre reformas institucionais e política fiscal. A crítica aos déficits fiscais, não surpreendentemente, é o primeiro item do texto de Williamson, que deu origem ao conjunto de propostas posteriormente conhecido como Consenso de Washington. As palavras do texto de Williamson remetem ao que se discutiu na seção 3.1 como transição do paradigma político sobre política fiscal no Brasil: "Washington acredita em disciplina fiscal. [...] Crentes de esquerda em estímulo "keynesiano" via amplos déficits orçamentários são praticamente uma espécie em extinção" (WILLIAMSON, 1990). ${ }^{112}$ Em outras palavras, o texto de Williamson expressa a mudança do discurso internacional sobre política fiscal, estimulando a transição de um regime fiscal cujo principal objetivo era a manipulação da demanda agregada para um regime no qual a sustentabilidade da dívida pública se torna central.

Nota-se a semelhança entre o texto de Williamson e as seguintes passagens, retiradas dos debates legislativos da aprovação da Lei de Responsabilidade Fiscal e da exposição de motivos apresentada pelos Ministros Pedro Malan, Pedro Parente e Waldeck Ornelas, respectivamente: "o Brasil teve uma gestão financeira quase sempre irresponsável: gastava-se mais do que se arrecadava" (Deputado Federal Luiz Carlos Hauly, PSDB, DCD, p. 03664, Quarta-Feira, 26 de janeiro de 2000); “a sociedade brasileira reclama gestão austera dos recursos que confia ao Poder Público. É nosso dever assegurá-la, mediante instituição de um regime eficaz de responsabilidade fiscal" (grifo nosso). A utilização da expressão "gestão austera" e a ênfase nas palavras “disciplina" e "responsabilidade" não são fortuitas. Elas expressam a importância de se adequar as instituições nacionais às expectativas do discurso internacional sobre gestão fiscal e dívida pública. ${ }^{113}$

\footnotetext{
${ }^{111}$ No original: "hardening the budget constraint on subnational borrowing will help to forestall future debt crises. But ultimately, sustainable reform requires changing the political circumstances that gave rise to these policies. The distribution of power between the president and the legislature needs to be reexamined. [...]To make it harder for interest groups from the states to conspire against the whole, the office of the president must be strengthened".

${ }^{112} \mathrm{O}$ texto esclarece, no entanto, que a discussão sobre regras para um orçamento equilibrado (balanced budget) não eram consensuais no momento da escrita do texto, em 1990: "Diferenças de opinião existem, contudo, sobre se a disciplina fiscal implica necessariamente um orçamento equilibrado" (WILLIAMSON, 1990).

${ }^{113}$ Nesse sentido, ver também Nobre (2013), para quem: “se o governo FHC foi não poucas vezes contra a cartilha internacional daquele momento, se foi não poucas vezes, portanto, antiliberal na prática [...], sua
} 
Para além desses elementos, um último argumento em favor do efeito da sinalização é o de que a Lei de Responsabilidade Fiscal traz regras jurídicas que garantem melhores condições jurídicas aos credores de títulos da dívida pública. O exemplo mais claro é o do parágrafo $2^{\circ}$ do artigo $9^{\circ}$ da Lei. $\mathrm{O}$ referido parágrafo estabelece que, em situações nas quais a receita possa não ser suficiente para cumprir com as metas fiscais, as autoridades podem publicar atos restringindo gastos públicos. Contudo, o parágrafo determina: "não serão objeto de limitação as despesas que constituam obrigações constitucionais e legais do ente, inclusive aquelas destinadas ao pagamento do serviço da dívida" (grifo nosso). ${ }^{114}$ Esta regra, portanto, impossibilita que qualquer membro da Federação posponha ou atrase o pagamento de suas dívidas.

É importante ressaltar que, em dezembro de 1999, cinco meses antes da promulgação da Lei de Responsabilidade Fiscal, o Brasil tinha mais de US\$ 100 bilhões em total de dívida pública externa. ${ }^{115}$ A esse valor deve ser acrescido o valor que credores internacionais investiam no mercado doméstico da dívida pública. ${ }^{116}$ Para investidores, regras jurídicas favoráveis certamente garantem melhores condições para os investimentos do que o mero comprometimento político. Quando os dois elementos estão juntos, ainda melhor.

A aprovação da Lei de Responsabilidade Fiscal pelo governo brasileiro teve o objetivo de sinalizar aos credores que eles teriam melhores condições de investimento no país e, ao mesmo tempo, de que o desenho institucional e a gestão da política fiscal se adequariam a um discurso internacional sobre práticas fiscais. A inclusão da aprovação da lei como uma das reformas estruturais no acordo com o FMI fez parte

escora ideológica nunca deixou de ser o neoliberalismo triunfante dos anos 1990” (2013, p. 71). E, principalmente: "O sistema de metas representa um momento de apogeu técnico do neoliberalismo, servindo de instrumento de coordenação de diferentes elementos da abertura econômica de dimensão planetária nos anos 1990. [...] Juntamente com a introdução do sistema de metas de inflação, a aprovação da chamada Lei de Responsabilidade Fiscal, em abril de 2000, foi a grande novidade do segundo mandato de FHC". (2013, pp. 90 - 92).

${ }^{114}$ Regis Fernandes de Oliveira, ex-deputado federal, afirma que essa cláusula foi na realidade a única imposição do FMI na elaboração da lei (OLIVEIRA, 2013, p. 534). Contudo, ele não traz qualquer evidência empírica para apoiar sua afirmação.

${ }^{115}$ A informação é do Banco Central do Brasil. Ver:

<http://www.bcb.gov.br/htms/Infecon/DividaRevisada/14\%20Dados\%20economicos_financeiros.pdf> (ultimo acesso em 6 de outubro de 2014).

${ }^{116}$ Embora não haja informação sobre o ano de 1999, a informação publicada pela Secretaria do Tesouro Nacional mostra que somente no mês de novembro de 2000, instituições estrangeiras foram responsáveis por comprar 39,2\% dos títulos negociados no mercado doméstico, o equivalente a US\$ 4,7 bilhões (quatro bilhões e setecentos milhões de dólares). Dados do Relatório Mensal da Dívida Pública, publicado mensalmente pela Secretaria do Tesouro Nacional desde novembro de 2000 e disponível em: <https://www.tesouro.fazenda.gov.br/images/arquivos/Divida_publica/Publicacoes/Relatorio_Mensal/rela torio_nov_2000.pdf> (último acesso em 6 de outubro de 2014). 
desse processo de sinalização. Apesar disso, não é possível concordar com o discurso de que a aprovação da lei foi uma imposição do FMI. Além dos elementos já descritos nas seções anteriores que demonstram a existência de uma agenda autônoma e gerida domesticamente no governo federal para consolidação de um novo regime jurídico para a política fiscal, ainda que sob diferentes influências internacionais, é possível argumentar que até mesmo a inclusão da aprovação da Lei de Responsabilidade Fiscal no acordo com o FMI foi do interesse de elites políticas organizadas no Poder Executivo Federal.

\title{
3.2.4. O desejo doméstico pelo acordo: alavancando os esforços do governo federal na aprovação de reformas estruturais
}

Com base em uma conversa com o ex-presidente Fernando Henrique Cardoso, Vreeland sugere que foi o próprio governo federal brasileiro que quis o apoio do FMI para aprovar reformas estruturais contra a resistência de adversários domésticos. Essa é a sua narrativa:

\begin{abstract}
O presidente Cardoso entrou em um acordo com o FMI no final de 1998. O Presidente Cardoso tentou por anos a aprovação de algumas medidas, mas encontrou resistência de dentro da coalizão governista. Após a crise financeira do Leste Asiático, Cardoso apresentou as mudanças como necessárias para ganhar o apoio do FMI: “O mundo inteiro está nos observando, nos observando para ver se somos capazes de resolver essa crise". Sob essa supervisão, aqueles resistentes a reforma aquiesceram em algumas questões, e a velocidade das reformas se acelerou. (Vreeland, 2007, p. 65, tradução e grifo nossos) $)^{117}$
\end{abstract}

Observa-se que, em uma manifestação pública, o ex-Presidente retoricamente recorreu à arena internacional para argumentar em favor das reformas, entre as quais estava a aprovação da Lei de Responsabilidade Fiscal. Outros membros da coalizão

\footnotetext{
${ }^{117}$ No original: "President Cardoso entered into an IMF arrangement at the end of 1998 [...]. President Cardoso had been trying for years to get the approval for some of these measures but met resistance from within his government coalition. After the East Asian Financial crisis, Cardoso presented the changes as necessary to win IMF approval: "The whole world is watching us, watching to see if we'll be able to resolve the crisis." Under such scrutiny, those resisting reform acquiesced on some issues, and the pace of reforms stepped up".
} 
governista usaram discursos semelhantes na esfera pública. É esse fenômeno que esta pesquisa chama de "efeito de alavancagem".

Para se compreender o efeito da alavancagem, é essencial ter clareza de que a aprovação da Lei de Responsabilidade Fiscal era do interesse do Poder Executivo Federal. Como se demonstrou principalmente na seção 3.1., o governo federal perseguia a agenda do ajuste fiscal pelo menos desde 1993 e apresentava a lei como um dos elementos-chave para sua promoção. Ainda, a lei era fundamental para dar mais poder fiscal ao Poder Executivo Federal no controle das contas públicas, como discutido no capítulo anterior.

Uma vez aceito que a reforma era do interesse dos agentes do Executivo, resta analisar se a inclusão da aprovação da lei no acordo com o FMI pode ter facilitado sua aprovação em um Congresso potencialmente contrário a ela, facilitando os esforços do Executivo.

Nos debates legislativos, o argumento que prevaleceu entre a maioria dos parlamentares foi o de que a aprovação da Lei de Responsabilidade Fiscal seria um passo necessário na consolidação nacional e internacional da credibilidade do governo brasileiro com a sustentabilidade das contas públicas. ${ }^{118}$ Tanto a oposição como os partidos da coalizão reconheceram que o FMI criou o contexto no qual a aprovação da lei era considerada urgente, embora a maior parte dos argumentos em favor do projeto fosse basicamente relativa a questões domésticas, como corrupção e necessidade de controle do endividamento dos estados e municípios.

Certas passagens da discussão legislativa do projeto da Lei de Responsabilidade Fiscal demonstram que o acordo com o FMI foi utilizado por parlamentares da base de apoio do governo como motivo para justificar a necessidade de aprová-lo naquele momento. Em outras palavras, algumas declarações no processo de aprovação confirmam que o acordo com o FMI pode ter acelerado a aprovação da medida. Esse foi o caso dos Deputados Federais Bispo Rodrigues, que falou pelo Partido Liberal, e João Herrmann Neto, que falou pelo Partido Popular Socialista. Ambos votaram a favor da lei, reconhecendo: "a velocidade com que esse projeto foi encaminhado e a força da

\footnotetext{
${ }^{118}$ O deputado federal Luiz Carlos Hauly, falando pelo PSDB na Câmara dos Deputados, afirmou: "Lamentavelmente, os investimentos no país estão cada vez menores, porque a inconseqüência dos gastos feitos no passado levou ao endividamento a União, os estados e os municípios. Por essa razão, é preciso administrar com responsabilidade. A administração com responsabilidade gera credibilidade. [...] Há aqueles inconsequentes e irresponsáveis que pregam a moratória. Essa é danosa à economia brasileira, porque diminui a aplicação interna e externa no país, porque as pessoas deixam de acreditar no governo" (DCD, 26 de Janeiro de 2000, p. 03664-03665).
} 
base governista mostram claramente a pressão que o FMI faz para a aprovação" (João Herrmann); "Sabemos, não somos ingênuos; ingênuo nesta Casa normalmente é suplente - que estamos votando algo que interessa ao FMI, ou seja, o ajuste das contas dos países devedores, como garantia do pagamento dos juros. Mas achamos que é interessante para o País e votamos "sim”." (DCD, Quarta-Feira, 26 de Janeiro de 2000, p. 03665; 03690). ${ }^{119}$ Essas passagens demonstram que o acordo com o FMI fez parte do contexto de aprovação da Lei de Responsabilidade Fiscal e que os parlamentares viam a participação do organismo multilateral como um dos motivos pelos quais a reforma tinha sido acelerada.

O efeito de alavancagem, contudo, pode ser melhor apreendido pela análise de jornais, entrevistas de autoridades do Poder Executivo e discursos públicos. Os jornais representaram, nesse caso, a pressão que autoridades do Executivo e parte da opinião pública exerciam sobre os parlamentares para aprovação da lei. O arranjo com o FMI era frequentemente mencionado como uma forma de acelerar a aprovação do projeto.

Dois exemplos retirados do jornal Folha de São Paulo servem de evidência da hipótese de que o acordo com o FMI era usado para acelerar a aprovação da Lei de Responsabilidade Fiscal. Em junho de 1999, dois meses após o Executivo ter enviado o projeto para o Congresso, a Folha de São Paulo publicou partes de uma entrevista com Pedro Malan, dizendo:

Pelo acordo com o FMI, o Brasil deve terminar o ano com um superávit primário (que não conta o pagamento de juros) de $3,1 \%$ do PIB (soma de tudo o que é produzido no país). [...] Para alcançar a meta fiscal, Malan disse que o governo, além de estudar corte de gastos, conta com a ajuda do Congresso na aprovação da reforma tributária e da Lei de Responsabilidade Fiscal. "O Congresso está consciente do quanto é preciso fazer no campo fiscal. Há uma lei fundamental de responsabilidade fiscal sendo discutida. As coisas estão se movendo, o Congresso não está paralisado." (FSP, 1999a)

A mensagem do Ministro da Fazenda era clara: o Congresso tinha que ajudar o governo a obter uma meta de superávit fiscal com o FMI por meio da aprovação da Lei de Responsabilidade Fiscal. Para pressionar o Congresso, o Ministro fazia uso tanto da meta fiscal do acordo - que, aliás, tinha sido diretamente estabelecida em negociação

${ }^{119}$ A fala do Deputado Federal Bispo Rodrigues também reforça a hipótese sobre o efeito de sinalização. 
entre Executivo e Fundo, da qual o Legislativo não participou - como do próprio veículo de comunicação, um dos maiores jornais de circulação no país.

A própria Folha de São Paulo, dois meses mais tarde, em um editorial de 8 de agosto de 1999 com o título "Medo da Responsabilidade", e aparentemente convencida pelos argumentos de Malan, afirmaria:

Merece confiança e crédito apenas quem é responsável. Não é portanto por mero capricho que o FMI vem insistindo na aprovação da Lei de Responsabilidade Fiscal como um elemento decisivo na recuperação da credibilidade do Brasil nos mercados financeiros internacionais. (FSP, 1999b)

Reportagens semelhantes podem ser encontradas em outros jornais, como Estado de São Paulo, O Globo e Correio Braziliense. Nelson Torreão, escrevendo para o Correio Braziliense no dia 5 de junho de 1999, por exemplo, perguntava-se: "que sinal estaríamos enviando para o mundo - nós mesmos incluídos - ao rejeitarmos uma proposta que pretende instituir no país a responsabilidade no trato com dinheiro público? A de que aprovamos irresponsabilidade, não menos que isso". No mesmo sentido, o editorial do Estado de São Paulo de título "Contas que não tranqüilizam", de 27 de fevereiro de 2000: “O governo, nos três níveis, precisa continuar gerando superávit primário, inclusive superior ao do ano passado, como está previsto no acordo com o FMI. Daí a enorme importância da Lei de Responsabilidade Fiscal". ${ }^{120}$

Como se percebe, o efeito de alavancagem é simbólico e uma análise detalhada dos discursos públicos e de reportagens e entrevistas é essencial para compreendê-lo. $\mathrm{O}$ fato de que os jornais brasileiros não eram contrários ao acordo com o FMI foi provavelmente importante para que os membros do executivo usassem-no como mecanismo para alavancar os esforços de reforma do Executivo. $\mathrm{O}$ uso da esfera internacional como modo de alavancar os esforços do governo federal na aprovação da Lei de Responsabilidade Fiscal estava presente.

\subsection{Combinando "consenso" doméstico com influência internacional}

Reconhecer o papel do FMI e da esfera internacional na aprovação da Lei de Responsabilidade Fiscal não implica concluir que o Fundo impôs o novo regime

\footnotetext{
${ }^{120}$ Ver ainda da Folha de São Paulo: "Ministro quer lei aprovada até janeiro" (15 de dezembro de 1999); "Governo quer tornar infrator inelegível" (18 de janeiro de 2000).
} 
jurídico da política fiscal ao Brasil. Este capítulo não teve o objetivo de afirmar que atores internacionais e o discurso internacional sobre política fiscal determinaram a criação de instituições domésticas, mas que eles tiveram um papel considerável, em particular na aprovação da Lei de Responsabilidade Fiscal, uma das reformas estruturais descritas pelos acordos entre Brasil e FMI. Hoje, concordando-se ou não com a Lei de Responsabilidade Fiscal, ela é peça-chave para compreender a gestão da política fiscal no país, visto que consolida o regime jurídico da política fiscal no Brasil.

A literatura da ciência política discutida neste capítulo sugere que fatores domésticos explicam a aprovação da lei. Sem colocar em dúvida a descrição de como esses fatores domésticos impactaram a criação da lei, o capítulo tentou sugerir que a esfera internacional exerceu pelo menos quatro vetores de influências significativas adicionais: contexto para aceleração da reforma; parâmetros de excelência para comparação; a reforma institucional sinalizaria boas práticas a investidores e credores; alavancagem dos esforços do governo federal contra eventuais opositores da lei.

Dessa nova perspectiva, fatores domésticos continuam sendo centrais na explicação da aprovação da Lei de Responsabilidade Fiscal, mas o papel da esfera internacional é ressaltado.

Sem o "consenso" do governo federal a respeito da necessidade de uma Lei de Responsabilidade Fiscal, muito dificilmente ela seria aprovada nos termos e com a velocidade que foi. Além disso, as principais questões discutidas no momento da aprovação da lei eram domésticas: controle do endividamento dos estados e municípios; restrições de operações de crédito; limites de gasto com pessoal e por poder; mudança da suposta cultura de irresponsabilidade.

Entretanto, a esfera internacional é fundamental para compreender as escolhas normativas e até gramaticais da Lei de Responsabilidade Fiscal. A diferenciação da economia brasileira em relação a outras economias emergentes desejada pelo governo federal não poderia sequer ser pensada em termos de política fiscal se não houvesse um discurso considerado, na esfera internacional, mais apropriado para lidar com a política.

Para os fins deste capítulo, é importante ressaltar, mais uma vez, que não se discute o mérito do discurso internacional a respeito da necessidade de aprovação de leis de responsabilidade fiscal que promovam a austeridade e tentem reduzir a discricionariedade de políticos nacionais. O que importa é descrever como esse discurso forneceu às elites políticas brasileiras um modelo para o desenho da reforma jurídica da política fiscal que seria implementada ao longo da década de 1990, culminando com a 
aprovação da Lei de Responsabilidade Fiscal. Futuras pesquisas interdisciplinares podem se perguntar sobre as razões pelas quais esse discurso se originou a partir da década de 1970, principalmente em países desenvolvidos e como ele se consolidou com propostas específicas de reformas jurídicas, tanto em países desenvolvidos como em países em desenvolvimento.

Em termos teóricos, a descrição do processo brasileiro de aprovação da Lei de Responsabilidade Fiscal parece se relacionar com as literaturas da ciência política e de relações internacionais que trabalham com a ideia de "fontes internacionais da política doméstica". Em um dos textos mais recentes dessa literatura, Bernstein e Cashore (2012), embora discutindo o caso de políticas ambientais, concluem que existem quatro caminhos de influências internacionais nas políticas domésticas: regras internacionais (o foco tradicional da literatura); discursos internacionais; criação ou intervenção em mercados; acesso direto aos processos políticos domésticos.

No caso da aprovação da Lei de Responsabilidade Fiscal, os dois primeiros caminhos estavam claramente presentes. O FMI e o acordo stand-by demandando a aprovação da Lei como uma das reformas estruturais representou o caminho da influência via regras internacionais, uma vez que a não aprovação da reforma poderia levar à rejeição de uma renovação do acordo. Por outro lado, a existência de experiências prévias internacionais com regras fiscais consideradas bem sucedidas, o estímulo ao uso de tais regras por países em crise pelo FMI e pelos credores internacionais e a hegemonia de certo discurso internacional sobre política fiscal mostram que o caminho de discursos internacionais também estava presente. Um estudo comparado futuro pode analisar a relevância de tais influências internacionais em reformas institucionais ao comparar países em situações semelhantes à brasileira que acabaram aprovando leis similares, incluindo a possibilidade de se discutir uma eventual autonomia dos discursos jurídicos frente aos discursos políticos e econômicos, muito semelhante ao que fez Maxfield no âmbito da legislação sobre independência do Banco Central. $^{121}$

Da perspectiva jurídica, o estudo do processo de aprovação de uma lei permite esclarecer quais eram as principais disputas políticas e econômicas no momento da aprovação de um novo regime jurídico, o que influencia a criação das normas jurídicas e pode orientar até mesmo seu funcionamento e sua aplicação. Essa é justamente uma das

\footnotetext{
${ }^{121}$ Por exemplo, Argentina (1999), Colômbia (2003) e Peru (2003), entre outros países, aprovaram leis de responsabilidade fiscal aproximadamente na mesma época.
} 
questões centrais que será discutida no próximo capítulo, em especial nas seções 4.3. e 4.4.. 


\section{Capítulo 4 - A implementação do regime jurídico para a política fisscal}

Neste capítulo, discutem-se os efeitos do novo regime jurídico para a política fiscal. Analisa-se a implementação desse regime nos quatro âmbitos delineados pela análise da reforma do regime jurídico realizada no capítulo 2: relações federativas; relação entre Executivo e Legislativo; política fiscal do setor público consolidado baseada em regras; e novos mecanismos de transparência e de prestação de contas na gestão das finanças públicas.

A reforma do regime jurídico trouxe regras e princípios que centralizaram o poder fiscal no Poder Executivo e no governo federal. Os dados reunidos pela literatura econômica - que estuda o impacto da Lei de Responsabilidade Fiscal na gestão fiscal de estados e municípios - e pela literatura jurídica e política - que estuda o impacto do regime nas relações entre os poderes Executivo e Legislativo - confirmam que, nesses âmbitos, a concentração prevista no momento da criação das regras e dos princípios gerou o efeito esperado. Estados e municípios têm hoje um espaço reduzido para gerir autonomamente suas finanças; o Executivo passou a predominar em relação ao Legislativo nas decisões fiscais, o que facilitou a promoção de um ajuste fiscal, a partir do momento em que essa agenda se consolidou politicamente.

No âmbito da prática da política fiscal do setor público consolidado, esta pesquisa argumenta que o governo federal possui mais discricionariedade na gestão da política fiscal do que geralmente se considera em algumas pesquisas anteriores sobre o tema. Essa conclusão confirma as hipóteses da literatura internacional sobre os riscos da utilização de regras numéricas para governar a política fiscal. Além disso, abre espaço para a discussão da importância das ideias econômicas das elites políticas, em especial do Ministério da Fazenda, e da relação política entre Poder Executivo e Poder Legislativo na gestão fiscal, dado o regime jurídico atual.

Por fim, o último âmbito de análise discute os novos mecanismos de transparência e de prestação de contas criados pelo novo regime jurídico da política fiscal. Demonstra-se como esse regime valoriza a publicidade de certas informações sobre a gestão fiscal que priorizam o objetivo da sustentabilidade da dívida pública, em detrimento de outras possíveis funções que a política fiscal poderia ter. A pesquisa sobre transparência também demonstra que há, atualmente, uma agenda de reforma institucional na gestão da política fiscal, que vem inclusive sendo promovida por organismos multilaterais. 
A discussão realizada neste capítulo sobre a implementação do novo regime jurídico da política fiscal não aborda dois debates que são comuns na literatura do direito financeiro: sobre a importância do Poder Judiciário em decisões orçamentárias e sobre a importância dos crimes contra as finanças públicas. Não se trata de defender que esses âmbitos não tenham relevância na discussão de direito e macroeconomia, mas sim de argumentar que eles não são centrais para a compreensão das principais decisões a respeito da política fiscal no Brasil e da reforma do regime jurídico da política fiscal analisada por esta pesquisa.

No caso do Poder Judiciário, embora tenha sido um ator central no momento de consolidação do novo regime jurídico da política fiscal, como se mostrou no capítulo 2 ao declarar constitucionais ou inconstitucionais algumas previsões da Lei de Responsabilidade Fiscal - a partir do momento em que o regime passou a funcionar, o Judiciário não tem participado de discussões centrais sobre a gestão da política fiscal. É verdade que o entendimento jurisprudencial sobre a possibilidade de discussão das leis orçamentárias em abstrato foi alterado na Ação Direta de Inconstitucionalidade $n^{\circ} 4.048 / 2008$. Nesta ação, o Supremo Tribunal Federal, por 6 votos a 5 e revisando sua jurisprudência, reconheceu sua competência para exercer o controle abstrato de constitucionalidade de normas orçamentárias. Contudo, isso não tem sido usado para discutir as decisões macroeconômicas sobre política fiscal, como, por exemplo, a quantidade de gastos públicos e as metas de superávit para o setor público consolidado. $\mathrm{Na}$ prática, a mudança de orientação de jurisprudência tem se restringido ao questionamento da constitucionalidade da abertura de créditos extraordinários por meio de Medida Provisória. ${ }^{122}$ Um raciocínio semelhante pode se aplicar às questões relativas aos temas da judicialização das políticas públicas, como nas decisões sobre direito à saúde, acesso a medicamentos e de serviços de creche, por exemplo. Nesses casos, embora as decisões digam respeito ao orçamento e política públicas, muitas vezes representando uma intervenção significativa, elas não tendem a interferir no debate

\footnotetext{
${ }^{122}$ Ver o estudo de jurisprudência de Vasconcelos (2010) sobre o assunto: "A esta ADI [4048/2008] se seguiram mais cinco. Apenas na ADI 4049/2008 repetiu-se o resultado, pelo deferimento da liminar, sob os mesmos argumentos da ADI 4048/2008. Em todas as outras quatro, todas ajuizadas também em 2008, apesar de recepcionarem este novo entendimento, não houve provimento da liminar pleiteada, inclusive, sendo prejudicadas por perda de eficácia da norma orçamentária discutida. Este fato parece indicar que a Corte, mesmo formando um novo precedente, que lhe torna possível uma maior interferência, escolhe não interferir, utilizando o tempo para julgamento das demais ações como um instrumento oportuno, diante de uma aparente falta de interesse em interferir definitivamente em todos os casos. Abriu-se a oportunidade, mas não parece que o STF está inclinado a utilizá-la.” (2010, p. 155).
} 
macroeconômico sobre a política fiscal no país. ${ }^{123}$ Não se tem conhecimento de qualquer decisão do Poder Judiciário que tenha impactado a gestão da política fiscal do setor público consolidado, até o momento, afetando significativamente as metas de superávit primário ou a perseguição dessas metas, por exemplo.

No caso da discussão sobre os crimes contra as finanças públicas, é verdade que quando da aprovação da Lei de Responsabilidade Fiscal, a criação de tipos penais foi ressaltada por diversos atores como central para a instituição do novo regime fiscal. Essa era a opinião, inclusive, do Presidente Fernando Henrique Cardoso e do FMI, à época. ${ }^{124}$ Entretanto, reproduzir tais declarações como se suas premissas fossem verdadeiras seria temerário, por alguns motivos. Em primeiro lugar, seria difícil afirmar a existência de uma relação de causa e consequência entre a criação dos crimes e a gestão da política fiscal, uma vez que essa tipificação foi posterior à criação de todas as demais regras discutidas anteriormente. Além disso, a mera previsão de consequências criminais por desrespeito às leis fiscais pode ter o efeito geral de prevenção que costuma ser discutido pelas teorias da pena. Ou seja, os servidores públicos podem deixar de

\footnotetext{
${ }^{123}$ Embora possam inviabilizar decisões orçamentárias de certos entes federativos, em especial de municípios. O tema, contudo, é empiricamente controverso: no caso da judicialização da saúde, por exemplo, enquanto Ferraz salienta os possíveis impactos negativos de ações individuais discutindo o direito à saúde (FERRAZ, 2011), Fanti ressalta aspectos positivos derivados de alterações substantivas no conteúdo de políticas públicas de saúde por meio da litigância judicial (FANTI, 2009).

${ }^{124}$ No discurso de sanção da Lei de Responsabilidade Fiscal, o Presidente chegou a afirmar, fazendo referência à Lei dos Crimes Contra as Finanças Públicas, a Lei 10.028/2000, aprovada quatro meses depois da Lei de Responsabilidade Fiscal: "Esta lei vem, portanto, neste bojo de um espírito novo, que é um espírito que não quer encobrir nada e quer, sim, punição. Tanto quer punição que junto há uma outra lei - e o Deputado Michel Temer, Presidente da Câmara, acaba de me informar que, nas próximas semanas, será votada na Câmara dos Deputados - que é uma lei que penaliza aqueles que, eventualmente, venham a se desviar do curso da boa regra da Administração Pública limpa e correta". Disponível em: <http://www.biblioteca.presidencia.gov.br/ex-presidentes/fernando-henrique-cardoso/discursos-1/2omandato/1o-semestre/48.pdf/download> (último acesso em 21 de outubro de 2014). Um ano após a aprovação da Lei de Responsabilidade Fiscal, no já mencionado relatório de observância dos padrões e códigos de transparência fiscal, o FMI observou: "Adicionalmente às sanções institucionais e penalidades por não cumprimento estabelecidas pela LRF, os servidores públicos também podem ser responsabilizados pelas sanções e penalidades detalhadas na Lei de Crimes Fiscais (LCF). Parte integral da agenda brasileira de reforma fiscal estrutural, a LCF é aplicável a agentes públicos do executivo, legislativo, e do judiciário dos governos municipais, estadual e federal, assim como de suas agências descentralizadas e empresas públicas. Entre outros dispositivos, a LCF prevê a detenção por até 4 anos de agentes públicos" (FMI, 2001, p. 8-9, tradução nossa, grifos no original). No original: "In addition to the institutional sanctions and penalties for noncompliance provided by the LRF, public officials are liable to the sanctions and penalties in the Fiscal Crimes Law (LCF). As an integral component of Brazil's structural fiscal reform agenda, the LCF applies to public officials of the executive, legislative and judiciary branches of federal, state, and municipal governments, as well as their decentralized agencies and public enterprises. Among other provisions, the LCF provides for detention of up to four years for public officials."
} 
cometer crimes simplesmente porque a sanção penal passou a existir - o que seria difícil de avaliar mesmo em pesquisas qualitativas com servidores públicos. ${ }^{125}$

Nesse contexto, esta dissertação entende que a criação de leis penais não foi e não é central para o funcionamento do novo regime jurídico da política fiscal no país. Enquanto formas de responsabilização e prestação de contas dos políticos responsáveis pelas decisões centrais de política fiscal, dois mecanismos são mais relevantes: no caso de estados e municípios, os mecanismos institucionais que dão poder à União para sancionar administrativa e financeiramente os entes federativos que desrespeitem regras fiscais, o que gera a possibilidade de descontinuidade administrativa na eventualidade de desrespeito a tais normas, como será discutido na seção 4.1.; no caso da União, mas também dos estados e municípios, os mecanismos de limitação da discricionariedade e de transparência que facilitam o controle social (inclusive por agentes de mercado) da política fiscal discutidos nas seções 4.3. e 4.4..

As seções deste capítulo, portanto, discutem a implementação do regime jurídico para a política fiscal em quatro âmbitos: relações federativas; relação entre Executivo e Legislativo; política fiscal do setor público consolidado baseada em regras; e novos mecanismos de transparência na gestão das finanças públicas.

\subsection{Centralização da política fiscal: mudanças da relação federativa}

Pesquisas quantitativas demonstram que a Lei de Responsabilidade Fiscal foi responsável por uma mudança substantiva na gestão municipal e estadual das finanças públicas. As pesquisas quantitativas mencionadas nesta seção tentam compreender se a Lei de Responsabilidade Fiscal ou outras variáveis institucionais, como a Lei de reestruturação das dívidas estaduais, podem ser interpretadas como variáveis relevantes na mudança do padrão de endividamento de estados e municípios. Essa literatura é relevante para os fins dessa pesquisa porque mostra que regras e princípios jurídicos consolidados em lei representaram uma modificação na gestão fiscal de estados e municípios. A metodologia utilizada pelas pesquisas estudadas por esta dissertação está resumida no anexo desta dissertação; na sequência, são sistematizadas suas conclusões.

Quanto à gestão municipal, a revisão da literatura indica que a Lei de Responsabilidade Fiscal:

\footnotetext{
${ }^{125}$ A validade das teorias da prevenção geral tem sido colocada em xeque por estudos recentes, como demonstra Klaus Gunther em seus textos Crítica da Pena I e II (GUNTHER, 2006, 2007). Ver também o doutorado de Machado (2007).
} 
(i) Provoca um maior equilíbrio entre receitas e despesas; ${ }^{126}$

(ii) Facilita o cumprimento de objetivos legais e a publicação periódica de relatórios; ${ }^{127}$

(iii) Contribui para o aumento do superávit primário; ${ }^{128}$

(iv) Contribui para a redução da proporção entre dívida pública municipal e PIB municipal. ${ }^{129}$

A literatura enfatiza que a Lei de Responsabilidade Fiscal provoca essas mudanças geralmente por meio de um impacto negativo no montante total de investimento municipal em infraestrutura, que é um gasto menos rígido dentre as despesas públicas dos Municípios, e por um aumento da arrecadação superior ao aumento das despesas. ${ }^{130}$

Além disso, a literatura sugere que a Lei de Responsabilidade Fiscal pode ter se equivocado na estipulação de um limite de $60 \%$ do total das receitas líquidas dos Municípios no gasto público com pessoal, uma vez que a maior parte dos Municípios estava consideravelmente abaixo desse limite. Nesse sentido, o limite nominal se tornou um verdadeiro objetivo, estimulando o aumento dos gastos públicos nessa categoria. ${ }^{131}$

No caso da gestão estadual das finanças públicas, a literatura não foca somente nos impactos da Lei de Responsabilidade Fiscal para a política fiscal, mas avalia também a influência da emenda constitucional que permitiu a reeleição de governadores e do Presidente (Emenda Constitucional $n^{\circ} 16$, de 4 de julho de 1997), e a Lei que

\footnotetext{
${ }^{126}$ Ver, nesse sentido: Alves e Santos (2011), Gadelha (2012), Menezes (2006), Fioravante, Pinheiro e Vieira (2006), Giuberti (2005), Araújo, Chieza e Silva Jr (2009) - para os municípios de Rio Grande do Sul -, Santolin, Jayme Jr. e Reis (2009) - para os municípios de Minas Gerais -, Sakurai (2005).

${ }^{127}$ Ver Alves e Santos (2011) - para os municípios de Rio Grande do Sul.

128 Ver, nesse sentido: Gadelha (2012), Gerardo e Nascimento (2002), Sakurai (2005) - para os municípios do Estado de São Paulo; Chieza, Araújo e Júnior (2009) - para os municípios de Rio Grande do Sul.

${ }^{129}$ Ver: Nunes e Nunes (2003), Linhares, Penna e Borges (2013) - para os municípios de Piauí.

${ }^{130}$ Ver Menezes (2006), Chieza, Araújo e Júnior (2009) - para os municípios de Rio Grande do Sul - e Santolin, Jayme Jr. e Reis (2009) - para os municípios mineiros com população inferior a 50 mil habitantes.

${ }^{131}$ Esse é o argumento de Santolin, Jayme Jr. e Reis (2009), Fioravante, Pinheiro e Vieira (2006), Menezes (2006), Giuberti (2005) e Linhares, Penna, Borges (2013). Outra observação realizada por Fioravante, Pinheiro e Vieira é a de que o limite de endividamento municipal previsto na LRF pode estar descalibrado em relação a certos municípios: "do período anterior à LRF para o período seguinte, houve uma concentração da dívida consolidada líquida dos municípios. Ou seja, o número de municípios que ultrapassavam o teto da LRF do primeiro para o segundo período diminuiu. No entanto, a participação da dívida desses municípios aumentou em relação ao total da dívida dos municípios. Nesse ponto, sugere-se uma análise da sustentabilidade da dívida dos municípios que ultrapassam o limite da LRF ou que estão muito próximos desse limite." (2006, p. 24).
} 
reestruturou as dívidas estaduais com o governo federal (Lei no 9.496/1997). A revisão de literatura aponta para as seguintes conclusões:

A Lei de reestruturação das dívidas estaduais e a Lei de Responsabilidade Fiscal são instrumentos que tendem a promover um equilíbrio geral entre receitas e despesas no nível estadual, em particular com controle dos gastos com pessoal; ${ }^{132}$

(ii) A Lei de Responsabilidade Fiscal tende a tornar a política fiscal menos pró-cíclica; ${ }^{133}$

(iii) A literatura sobre o impacto da emenda da reeleição é controversa: enquanto Nakaguma e Bender (2004) afirmam que a emenda intensifica os ciclos políticos dos gastos públicos, Simonassi e Cândido Júnior (2008), na mesma linha da literatura internacional sobre o tema, defendem que a emenda auxilia o processo de ajuste fiscal;

(iv) Dados disponibilizados pela Secretaria do Tesouro Nacional mostram que, após 1999, estados começaram a contribuir para o alcance das metas para o superávit do setor público consolidado e que, daquele ano em diante, até o ano de 2011, não houve um único ano no qual o superávit primário tenha sido negativo no âmbito estadual agregado, que soma os resultados primários de todos os estados (BRASIL, 2012).

As literaturas do direito financeiro e da ciência política contribuem com esses achados empíricos ao discutir em detalhes os mecanismos institucionais pelos quais tais resultados foram alcançados, em especial no caso da política fiscal estadual.

No caso da reestruturação das dívidas estaduais, após a promulgação da Lei $n^{\circ}$ 9.496/1997, todos os estados, com exceção de Amapá e Tocantins, assinaram contratos específicos com a União, por meio dos quais ela assumiu a dívida mobiliária dos entes subnacionais, bem como as obrigações oriundas de operações de crédito internas e externas não decorrentes da emissão de títulos da dívida pública, enquanto os estados se comprometeram a repagar a dívida assumida pela União em até 360

\footnotetext{
${ }^{132}$ Esse é o argumento de Soares, Ceretta, Coronel e Vieira (2012); Rocha e Rocha (2008) - somente para a Lei de reestruturação das dívidas estaduais; Simonassi e Cândido Júnior (2008) - embora caiba ressaltar que, quando os autores desagregaram os dados, não foram encontrados impactos significativos dessas leis nos estados da região sudeste; Rocha e Giuberti (2008); Nakaguma, Bender (2006); Silveira, Jordão (2002) e Mora (2002).

${ }^{133}$ Ver: Rocha e Giuberti (2008).
} 
prestações (30 anos), com possibilidade de prorrogação por mais 120 meses e atualizadas por uma taxa de juros mínima de $6 \%$ ao ano.

Há diferenças entre os contratos assinados, que variaram devido à indisponibilidade de bens e direitos de alguns estados para a quitação de $20 \%$ da dívida à vista exigida de forma universal pela União. As consequências pelo não pagamento à vista foram uma ou mais das seguintes medidas, na elaboração dos contratos: (i) estados se comprometeram a pagar 7,5\% de juros mais a correção mensurada pelo Índice Geral de Preços (IGP-DI), enquanto os demais estados se comprometeram a pagar $6 \%$ de juros mais correção ${ }^{134}$; (ii) o comprometimento da receita para pagamento da dívida variou até $15 \%$, enquanto o mínimo previsto foi de $11,5 \%$ e a média de $13 \%{ }^{135}$; (iii) a quitação do compromisso foi prevista em um prazo mais curto de 15 anos, ao invés de $30^{136}$ (MORA, 2002).

Os acordos de refinanciamento entre União e estados foram celebrados em um contexto no qual a União demandou outras contrapartidas dos entes subnacionais, para além do repagamento da dívida pelos estados. Em especial, previu-se a liquidação ou a privatização de empresas e bancos públicos estaduais. A venda das empresas públicas estatais, principalmente das empresas de energia elétrica, era prevista como um dos modos de se possibilitar o pagamento dos $20 \%$ da dívida à vista, exigido pela União (MORA, 2002, p. 29). A liquidação ou privatização de bancos públicos estaduais era também central na estratégia da União de controlar o endividamento subnacional, uma vez que eles eram dos principais instrumentos de endividamento dos estados. Além disso, a privatização e a liquidação das empresas e bancos supostamente facilitariam que os estados promovessem um programa de contenção de despesas e incremento das receitas, demandado pela União.

Como observa Mora, essas operações foram centrais para modificar o quadro deficitário dos estados nos primeiros anos após a renegociação das dívidas:

A evolução do Resultado Primário Ajustado mostra que o efeito do Programa de Reestruturação Fiscal e Financeira sobre as contas estaduais reverteu o quadro deficitário. Com um ponto de inflexão em

\footnotetext{
${ }^{134}$ Esses foram os casos de Pará, Alagoas e Minas Gerais.

135 Os estados de Pará, Rondônia, Alagoas, Mato Grosso, Mato Grosso do Sul e Goiás podem comprometer até $15 \%$ de sua receita.

${ }^{136}$ Piauí, Ceará e Rio Grande do Norte são os estados com prazo de quitação de 15 anos. Em busca no sítio eletrônico da Secretaria do Tesouro Nacional, que traz dados relativos a esses estados, somente o estado do Piauí liquidou o refinanciamento, encerrando o Programa em 6/6/2012. Ver:

<http://www3.tesouro.fazenda.gov.br/estados_municipios/reestruturacao_ajuste_fiscal.asp> (último acesso em 8 de outubro de 2014).
} 
1997, observou-se novamente o crescimento do déficit primário em 1998 (provavelmente relacionado às eleições para o governo estadual ocorrida ao final desse ano) e, a partir de 1999, uma reversão dessa trajetória. Tal resultado foi possível em decorrência do esforço fiscal dos estados, do aumento das transferências voluntárias e da postergação de gastos (com a utilização do artifício de restos a pagar). (MORA, 2002, p. 41)

A autora esclarece que, para os primeiros anos do ajuste, entre 1996 e 2000, a receita agregada resultante da privatização ou liquidação das empresas foi correspondente a um valor em torno de $\mathrm{R} \$ 38$ bilhões, o que foi fundamental para amortizar a dívida dos estados e manter o equilíbrio fiscal (MORA, 2002, p. 44). Como o pagamento dos $20 \%$ à vista cobrados pela União só alcançou o valor de $\mathrm{R} \$ 15,6$ bilhões, os recursos adicionais facilitaram a manutenção do equilíbrio fiscal nos anos seguintes. Quanto aos bancos públicos de propriedade dos estados, entre 1997 e 1999 , os dados reunidos por Mora demonstram que a maior parte deles foi privatizada ou liquidada, com poucas exceções (MORA, 2002, p. 46).

Por outro lado, a Lei de Responsabilidade Fiscal concedeu à União a prerrogativa de reter transferências voluntárias quando unidades da Federação desrespeitassem os limites das despesas com pessoal, de operações de crédito e das dívidas consolidada e mobiliária, além das regras relativas a restos a pagar e publicação de relatórios. Para estabelecer os limites relativos às dívidas consolidada e mobiliária, o Executivo enviou proposta ao Senado Federal, que aprovou a Resolução no 40 em 2001. Segundo a Resolução, a dívida consolidada dos Estados, do Distrito Federal e do Município, ao final do décimo quinto exercício financeiro contado a partir do encerramento do ano da publicação da Resolução, não poderia exceder 2 vezes a receita corrente líquida, no caso de Estados e do Distrito Federal, e 1,2 vezes a receita corrente líquida, no caso dos Municípios. A Resolução ainda previu que a apuração dos resultados deveria ser quadrimestral e enviada ao Ministério da Fazenda no Relatório de Gestão Fiscal. É importante ressaltar que a Resolução do Senado Federal $n^{\circ} 20$, de 2003, ampliou o prazo estipulado pelo art. 31 da Lei de Responsabilidade Fiscal para o cumprimento dos limites para a dívida consolidada em 4 quadrimestres, além de prever a suspensão da obrigatoriedade do cumprimento dos limites entre janeiro de 2003 e abril 
de 2005. Os dados relativos ao cumprimento desses limites podem ser observados no gráfico abaixo:

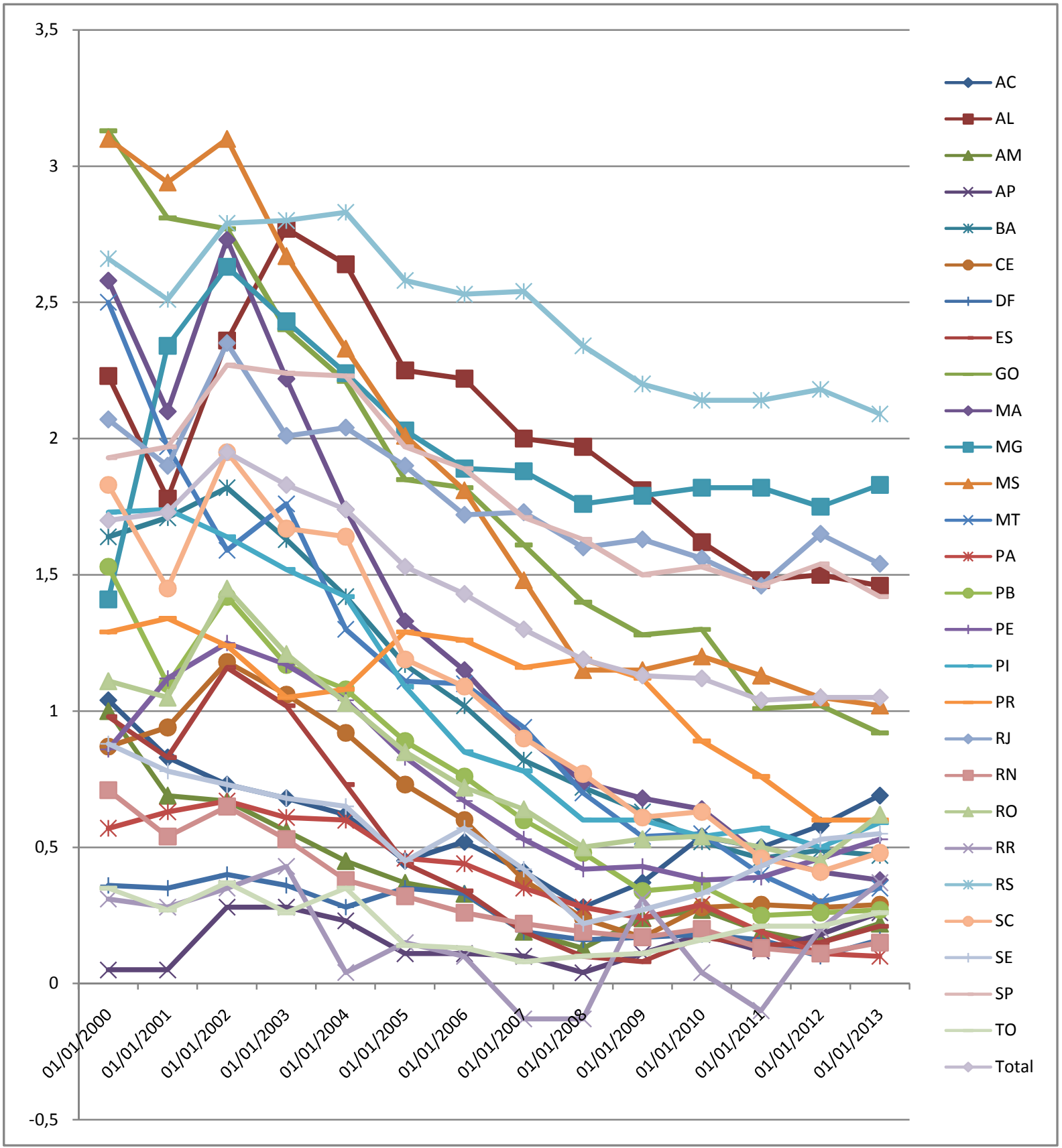

Gráfico 1: Comparação entre Dívida Consolidada Líquida e Receita Corrente Líquida. Fonte: STN ${ }^{137}$

137 Os dados atualizados podem ser encontrados em: <http://www.tesouro.fazenda.gov.br/dividaconsolidada-liquida> (último acesso em 12 de outubro de 2014).

Os dados utilizados por essa pesquisa estavam disponíveis em:

<http://www.tesouro.fazenda.gov.br/documents/10180/241999/PUBLICACAO_DCL_RCL_Estados_Pos icao_17-07-2014.pdf> (último acesso em 10 de agosto de 2014). 
É possível perceber uma redução contínua tanto em âmbito consolidado como em âmbito individual dos níveis de endividamento dos estados, em especial a partir de 2004. A tendência geral é de redução dos níveis de endividamento, medidos em termos da dívida consolidada líquida pela receita corrente líquida dos estados. ${ }^{138}$

A análise desses dados sugere ainda que não foi a punição ou o medo da sanção penal que fez com que estados procedessem à redução contínua do endividamento. Como se percebe pelos gráficos, mesmo após a aprovação da Lei de Responsabilidade Fiscal em 2000, e da Lei de Crimes contra as Finanças Públicas, do mesmo ano, alguns estados tiveram um aumento na proporção entre a dívida consolidada líquida e a receita corrente líquida, entre o final de 2000 e o final de 2002. Esse foi o caso de dezesseis estados e do Distrito Federal: Alagoas, Amapá, Bahia, Ceará, Distrito Federal, Espírito Santo, Maranhão, Minas Gerais, Pará, Pernambuco, Rio de Janeiro, Rondônia, Roraima, Rio Grande do Sul, Santa Catarina, São Paulo e Tocantins. A redução do endividamento deve ter se originado de outras fontes, como as que foram discutidas até aqui nesta seção, além das restrições às contratações de crédito previstas na Resolução do Senado Federal $\mathrm{n}^{\circ} 43$, de 2001, e das autorizações específicas às contratações de crédito externas, pelo Senado Federal, em decorrência de sua competência constitucional. ${ }^{139}$ Destacam-se, em especial, as metas previstas individualmente por cada estado frente à União no âmbito dos contratos celebrados individualmente a partir da Lei de reestruturação das dívidas estaduais para redução da relação entre dívida e receita líquida real e para obtenção de resultados primários.

Em síntese, é possível concluir que o novo regime jurídico da política fiscal promoveu uma redução generalizada da margem de manobra fiscal dos Estados e também dos municípios. A implementação do regime significou, para esses entes subnacionais, a privatização e a liquidação de empresas e bancos públicos, além do

\footnotetext{
${ }^{138}$ De acordo com a definição adotada pela Resolução do Senado Federal no 40, de 2001, a dívida consolidada líquida corresponde à dívida pública consolidada, deduzidas as disponibilidades de caixa, as aplicações financeiras e os demais haveres financeiros, excluídas as obrigações existentes entre as administrações diretas dos estados, do Distrito Federal ou dos municípios e seus respectivos fundos, autarquias, fundações e empresas estatais dependentes, ou entre estes. Já a receita corrente líquida corresponde ao somatório das receitas tributárias, de contribuições, patrimoniais, industriais, agropecuárias, de serviços, transferências correntes e outras receitas também correntes.

${ }^{139}$ A referida resolução, mencionada também no capítulo 2, impõe restrições a operações de crédito interno e externo. Quanto ao número absoluto de autorizações para contratação de crédito interno e externo, é interessante notar que, como observa Loureiro, houve redução a partir de 1997, com a aprovação da Lei de Reestruturação das dívidas estaduais: "Esses dados são significativos pois permitem analisar o comportamento do Senado em perspectiva ampliada. Mesmo sensível a pressões vindas dos governos estaduais (politicamente inevitáveis), ele tem se mostrado comprometido com o ajuste fiscal" (LOUREIRO, 2001, p. 58).
} 
surgimento de diversos mecanismos que buscam garantir um maior equilíbrio das contas públicas. Embora o Senado Federal tenha tido participação relevante nesse processo, defende-se que o Executivo Federal foi o poder mais fortalecido com a implementação do regime, o que se passará a discutir.

\subsection{Centralização da política fiscal: predominância do Executivo}

Como descrito no capítulo 2, a reforma do regime jurídico da política físcal não criou a centralização do poder fiscal na esfera do Poder Executivo em relação ao Poder Legislativo, mas certamente reforçou essa característica histórica do sistema políticojurídico brasileiro. A literatura jurídica sobre o tema é unânime em afirmar que as regras jurídicas aprovadas na década de 1990 concederam mais poder ao Executivo na gestão fiscal, especialmente por meio de dois mecanismos: (i) contingenciamento de recursos, principalmente pela previsão da Lei de Responsabilidade Fiscal de expedição de um decreto anual pelo Poder Executivo programando as despesas públicas; (ii) desvinculação das receitas da União. ${ }^{140}$

Lochagin apresenta um dos melhores resumos da relação entre Legislativo e Executivo no que diz respeito ao contingenciamento de recursos após as reformas jurídicas dos anos 1990 em sua dissertação de mestrado, A flexibilidade da execução orçamentária e o orçamento impositivo:

A disciplina legal do tema [de contingenciamento de recursos], conferida atualmente pela Lei de Responsabilidade Fiscal, autoriza a limitação de empenho e movimentação financeira numa hipótese específica, destinada a permitir o ajuste fiscal no caso de frustração da receita. Seu uso indiscriminado tem se firmado mais como um elemento das relações de poder existentes entre Executivo e Legislativo do que como uma ocorrência fundamentada na lei e na sistemática constitucional das atribuições parlamentares no orçamento público (LOCHAGIN, 2013, p. 151, grifo nosso)

Da perspectiva da presente pesquisa, importa ressaltar dois elementos dessa passagem de Lochagin: (i) o primeiro, descritivo, é o da concentração de poderes fiscais no Executivo após as mudanças advindas da Lei de Responsabilidade Fiscal e, principalmente, em decorrência da interpretação que tem se dado às regras na prática

${ }^{140}$ Além de Lochagin (2012), ver: Mendonça (2010), Faria (2009) e Dallaverde (2008). 
administrativa; (ii) o segundo diz respeito à importância do debate jurídico sobre a política fiscal, uma vez que a sugestão sobre a inconstitucionalidade do mecanismo de contingenciamento de recursos via decreto aponta para eventuais mudanças de interpretação que podem vir a existir no instituto, a despeito de seus impactos para a gestão da política macroeconômica.

No plano descritivo, os trabalhos da área demonstram como existe uma concentração de prerrogativas da fase de execução do orçamento nas mãos do Executivo. Os mecanismos de contingenciamento de despesas e a interpretação clássica do Direito Financeiro brasileiro de que o orçamento é meramente autorizativo ${ }^{141}$, por se tratar de mera lei formal, permitem que o Executivo (em todos os níveis de governo) tenha predominância na gestão das finanças públicas. ${ }^{142}$

Essa prática, que já era comum, consolidou-se na década de 2000, após a aprovação da Lei de Responsabilidade Fiscal. Em suma, todos os anos, um mês após a aprovação da lei orçamentária no Congresso, o Executivo publica um decreto determinando se, quando e quais gastos autorizados pela Lei Orçamentária Anual serão realizados. ${ }^{143}$ Ou seja, ainda que um gasto esteja previsto no Orçamento, caso ele não seja uma obrigação constitucional ou legal do órgão - como nos casos de pagamento de aposentadorias e pensões ou de pagamento do serviço da dívida - o Executivo pode simplesmente se negar a prever recursos para a despesa, independentemente de aprovação pelo Legislativo. Para ficar em apenas um exemplo, somente no ano de 2014, o contingenciamento de recursos chegou ao valor de $\mathrm{R} \$ 44$ bilhões em relação ao Orçamento aprovado. ${ }^{144}$

Por outro lado, o fato de tais práticas correrem o risco de serem declaradas inconstitucionais, como a passagem de Lochagin sugere - seja pela via da própria

\footnotetext{
${ }^{141}$ Ver, por exemplo, Oliveira (2013, pp. 400-416 e 449-450). Ver também: Faria (2009) e Giacomoni (2012, pp. 292-299).

${ }^{142}$ Ainda que o Legislativo seja chamado a participar da execução orçamentária nos casos de superação da autorização inicial para gastar ou da criação de nova autorização para gasto.

${ }^{143}$ Ver os Decretos no: 3.473/2000; 3.746/2001; 4.120/2002; 4.591/2003; 4.992/2004; 5.379/2005; $5.780 / 2006 ; 6.046 / 2007 ; 6.439 / 2008 ; 6.752 / 2009 ; 7.094 / 2010 ; 7.445 / 2011 ; 7.680 / 2012 ; 7.995 / 2013$; $8.197 / 2014$.

${ }^{144}$ Segundo Mendonça (2010), o Executivo pode inclusive se negar a realizar uma despesa, ainda que tenha disponibilizado os recursos, por simples omissão. Não há necessidade de qualquer justificação pela não realização dessa despesa. Ademais, como se afirmou no capítulo 2, o espaço para contingenciamento de recursos é significativamente reduzido quando se leva em consideração que grande parte dos recursos arrecadados no país é imediatamente vinculada a gastos legais e constitucionais. No ano de 2013, as despesas discricionárias somaram cerca de $11 \%$ do orçamento o que, no âmbito do Executivo, representou o valor aproximado de R $\$ 254$ bilhões. De qualquer modo, o contingenciamento continua sendo um mecanismo relevante para influenciar os gastos públicos no país.
} 
interpretação administrativa ${ }^{145}$, seja pela aprovação de reformas legislativas e/ou constitucionais que instituam o orçamento impositivo ${ }^{146}$, seja ainda por uma declaração de inconstitucionalidade via Supremo Tribunal Federal -, demonstra a relativa autonomia do discurso jurídico e a importância de se discutir direito e macroeconomia a partir da perspectiva da indeterminação do direito, que se discutiu ao final do capítulo 2. A relativa autonomia do discurso jurídico existe devido ao discurso doutrinário que aponta a possível inconstitucionalidade da prática institucional do contingenciamento. Não parece ser impossível imaginar que esse discurso se torne hegemônico no futuro e acabe gerando consequências institucionais. Nesse sentido, há possibilidade de modificação da prática que teria efeitos profundos na gestão da política fiscal.

À prerrogativa atribuída pela Lei de Responsabilidade Fiscal ao Executivo, Mendonça (2010) e Dias (2011) acrescentam a importância de serem consideradas na análise da relação entre Executivo e Legislativo as emendas constitucionais que permitem que o Executivo retenha $20 \%$ das receitas de impostos que a Constituição originalmente direcionaria a certas despesas. O mecanismo de "desvinculação de receitas da União" foi inicialmente aprovado em 1994 para conceder maior flexibilidade na execução orçamentária para o Executivo no contexto de criação do Plano Real e com a agenda de facilitar o ajuste fiscal. A previsão inicial era de que o mecanismo valeria por somente dois anos, até 1996. Contudo, desde sua criação em 1994, a emenda constitucional já foi renovada seis vezes e permanecerá em vigor, pelo menos, até 2015, como mostra a tabela abaixo:

\footnotetext{
${ }^{145}$ Com uma eventual e improvável modificação do entendimento do Poder Executivo sobre a prática do contingenciamento.

${ }^{146} \mathrm{Na}$ LDO 2014, aprovou-se de forma inédita uma regra restrita de orçamento impositivo. Por força do artigo 52 da LDO 2014, o Executivo foi obrigado a executar de forma equitativa a programação incluída por emendas individuais de parlamentares à lei orçamentária em montante correspondente a $1,2 \%$ da receita corrente líquida realizada no exercício anterior, sendo que a metade desse percentual será destinada a ações e serviços públicos de saúde. O adjetivo "tímido" é cabível aqui, pois a nova regra não altera a verdadeira discricionariedade do Executivo em determinar o contingenciamento, embora reduza sua competência para fazê-lo nos casos de emendas individuais. Sobre o tema, ver também: Faria (2009) e Lochagin (2013).
} 


\begin{tabular}{|l|l|l|}
\hline Denominação & Dispositivo & Vigência \\
\hline Fundo Social de Emergência(FSE) & ECR n ${ }^{\circ} 1 / 1994$ & $1994-1995$ \\
\hline Fundo de Estabilização Fiscal (FEF) & EC n ${ }^{\circ} 10 / 1996$ & $1996-1997$ \\
\hline FEF - Prorrogação & EC n $^{\circ} 17 / 1997$ & $1997-1999$ \\
\hline Desvinculação de Receitas da União & EC n $^{\circ}$ 27/2000 & $2000-2003$ \\
\hline DRU - Prorrogação 1 & EC n $^{\circ}$ 42/2003 & $2003-2007$ \\
\hline DRU - Prorrogação 2 & EC n $^{\circ}$ 56/2007 & $2008-2011$ \\
\hline DRU - Prorrogação 3 & EC n $^{\circ}$ 68/2011 & $2011-2015$ \\
\hline
\end{tabular}

Tabela 2: Histórico normativo da Desvinculação de Receitas da União. Elaboração própria a partir de Dias (2011).

Dias demonstra como, depois de 1999, a emenda constitucional passou a ser usada pelo governo federal para garantir superávits primários, embora em anos recentes essa importância tenha diminuído consideravelmente em termos de resultados primários (DIAS, 2011). O autor afirma, contudo, que o mecanismo constitucional é extremamente importante em face da rigidez das despesas públicas no país - ainda que a desvinculação não seja usada diretamente para o primário, o mecanismo continuaria sendo relevante para permitir que o Executivo distribua os recursos entre outras despesas não vinculadas, o que indiretamente auxiliaria o primário.

A rigidez orçamentária, que o mecanismo de desvinculação de receitas da União tenta mitigar, é uma das principais características da atual configuração da política fiscal no país. Como se demonstrou acima e no capítulo 2, o governo não possui ampla margem de manobra para modificar a gestão da política fiscal, uma vez que grande parte dos recursos já está destinada a despesas legais e constitucionais. A rigidez das despesas reduz a possibilidade de que diferentes governos utilizem a política fiscal para programas ou projetos distintos.

Rezende e Cunha discutem o fenômeno da rigidez orçamentária, afirmando que ele é resultado:

do acúmulo de pressões sobre o orçamento que se originam dos seguintes fatores: compromissos financeiros acumulados no passado; direitos assegurados em lei a grupos sociais mais bem organizados; regras que estabelecem os mecanismos de transferências de recursos fiscais na Federação; garantias instituídas com respeito ao financiamento de determinados programas governamentais. (REZENDE e CUNHA, 2003, p. 8) 
Para se ter uma ideia da dimensão da rigidez orçamentária, dentre os gastos previstos para o ano de 2013 na Lei Orçamentária Anual, somente gastos com pessoal e encargos sociais da União, que correspondiam a R \$ 222 bilhões, e gastos com juros, encargos da dívida e amortização da dívida, que somaram cerca de R\$ 718 bilhões, totalizaram R \$ 940, o que correspondeu a 41\% das despesas previstas no Orçamento. ${ }^{147}$ Não foram incluídos nesses cálculos os gastos com a previdência. A desvinculação das receitas da União deve ser interpretada como uma maneira pela qual o Executivo tem buscado se desvincular dessa rigidez.

A reforma do regime jurídico da política fiscal nos anos 1990 centralizou o poder fiscal nas mãos do Executivo federal, em especial com modificações na fase da execução orçamentária. Como a literatura internacional já aponta, conforme indicado no capítulo 1, um processo orçamentário centralizado e hierárquico geralmente facilita a disciplina fiscal. A centralização da gestão fiscal no Executivo promovida pelo novo regime jurídico da política fiscal, com a institucionalização do decreto de contingenciamento e com as emendas que permitem a desvinculação das receitas da União, pode ser lida nesse contexto: ela teve como objetivo facilitar o processo de ajuste fiscal, sobretudo por meio dos dois mecanismos discutidos nesta seção.

A questão que fica em aberto é saber se a centralização do poder fiscal também pode facilitar mudanças na gestão da própria política fiscal, caso ocorram trocas nas autoridades responsáveis pelas decisões políticas sobre as finanças públicas. Isso será abordado na próxima seção.

A literatura discutida nesta seção também demonstra que o desenho jurídico da política fiscal, que envolve a relação entre Executivo e Legislativo, relaciona-se a temas caros a um estado democrático, como separação de poderes e transparência nas decisões públicas relativas a orçamento. As questões relevantes para a política físcal não se resumem a discussões funcionais sobre a melhor gestão "técnica" da política físcal. Essas questões voltarão a ser discutidas na última seção deste capítulo, em conjunto com o estudo sobre a possível criação de um Conselho de Gestão Fiscal.

\footnotetext{
147 Os dados estão disponíveis em: <http://www.orcamentofederal.gov.br/informacoesorcamentarias/execucao-orcamentaria-1/publico_cgcon_execucao_gnd300914.pdf> (último acesso em 8 de outubro de 2014).
} 


\subsection{A discricionariedade da gestão política fiscal do setor público consolidado}

De acordo com alguns estudos, a aprovação do novo regime jurídico para a política fiscal impossibilitou seu uso como política anticíclica no país. Mesmo com a concentração de poder fiscal nas mãos do Executivo, algumas regras teriam limitado o uso da política fiscal para outros objetivos, para além de garantir sustentabilidade da dívida pública e a geração de superávits primários. Montes e Alves apresentam uma boa síntese desse entendimento:

O modelo de gestão de política fiscal implementado a partir de 1999 impõe restrições que limitam atuações contracíclicas capazes de ampliar o bem-estar social e que, por sua vez, se traduzem em custos mais elevados para a sociedade. [...] Um exemplo deste tipo de ação na gestão fiscal é a Lei de Responsabilidade Fiscal. [...] Para atingir o objetivo de sustentabilidade da política fiscal, o governo observa a evolução da relação dívida pública/PIB e faz uso do superávit primário como seu principal instrumento. (ALVES e MONTES, 2012, pp. 376-377) ${ }^{148}$

Ou seja, o que esta pesquisa chama de novo regime jurídico da política fiscal, consolidado com a Lei de Responsabilidade Fiscal, seria para esses autores a implementação de um regime institucional no qual a sustentabilidade da dívida pública teria se tornado o único e principal objetivo da política fiscal.

Novamente sem entrar no mérito do debate econômico sobre a necessidade de o Brasil gerar ou não superávits primários, esta pesquisa analisa se a implementação do regime jurídico da política fiscal pode contribuir na compreensão da gestão recente da política fiscal no Brasil e servir para confirmar ou não a hipótese desses autores. Ao

\footnotetext{
148 Essa parece ser a mesma perspectiva de Bercovici e Massonetto, que afirmam: "A Lei de Responsabilidade Fiscal e a insana proposta de emenda constitucional instituindo o déficit nominal zero são meios de excluir o orçamento da deliberação pública, garantindo metas de política monetária muitas vezes impostas de fora e em favor de interesses econômicos privados, que desejam uma garantia sem risco para seus investimentos ou para sua especulação financeira. A implementação da ordem econômica e da ordem social da Constituição de 1988 ficaram restritas, assim, às sobras orçamentárias e financeiras do Estado. A constituição financeira de 1988 foi, deste modo, "blindada". A Lei de Responsabilidade Fiscal apenas complementa este processo, ao vedar a busca do pleno emprego e a implementação de outra política financeira. Neste processo, é importante ressaltar a edição da Lei $n^{\circ} 10.028$, de 19 de outubro de 2000, que, dentre várias medidas draconianas, tipifica como crime a promoção do déficit público" (2007, pp. 87-89).
} 
contrário deles, esta dissertação sugere que o regime jurídico da política fiscal no país ainda parece permitir relevante grau de discricionariedade na gestão da política fiscal.

Para compreender qual é o grau de discricionariedade permitido pelo regime jurídico da política fiscal, é essencial analisar algumas variáveis da política fiscal nas duas últimas décadas. Nesse sentido, no gráfico abaixo, apresentam-se o superávit primário do setor público consolidado medido como porcentagem do PIB de 1991 a 2013, as metas explícitas para superávit primário como demandado por lei a partir de 1999 e as mesmas metas com as exceções permitidas por lei a partir de 2006.

O superávit primário, representado na linha azul, corresponde às despesas do governo, menos as receitas, excluindo-se do cálculo os juros da dívida. A linha vermelha representa as metas para o superávit primário do setor público consolidado, estabelecidos anualmente na Lei de Diretrizes Orçamentárias e suas eventuais revisões. Finalmente, o tracejado verde representa as metas para o superávit primário com as reduções legais permitidas pela Lei de Diretrizes Orçamentárias.

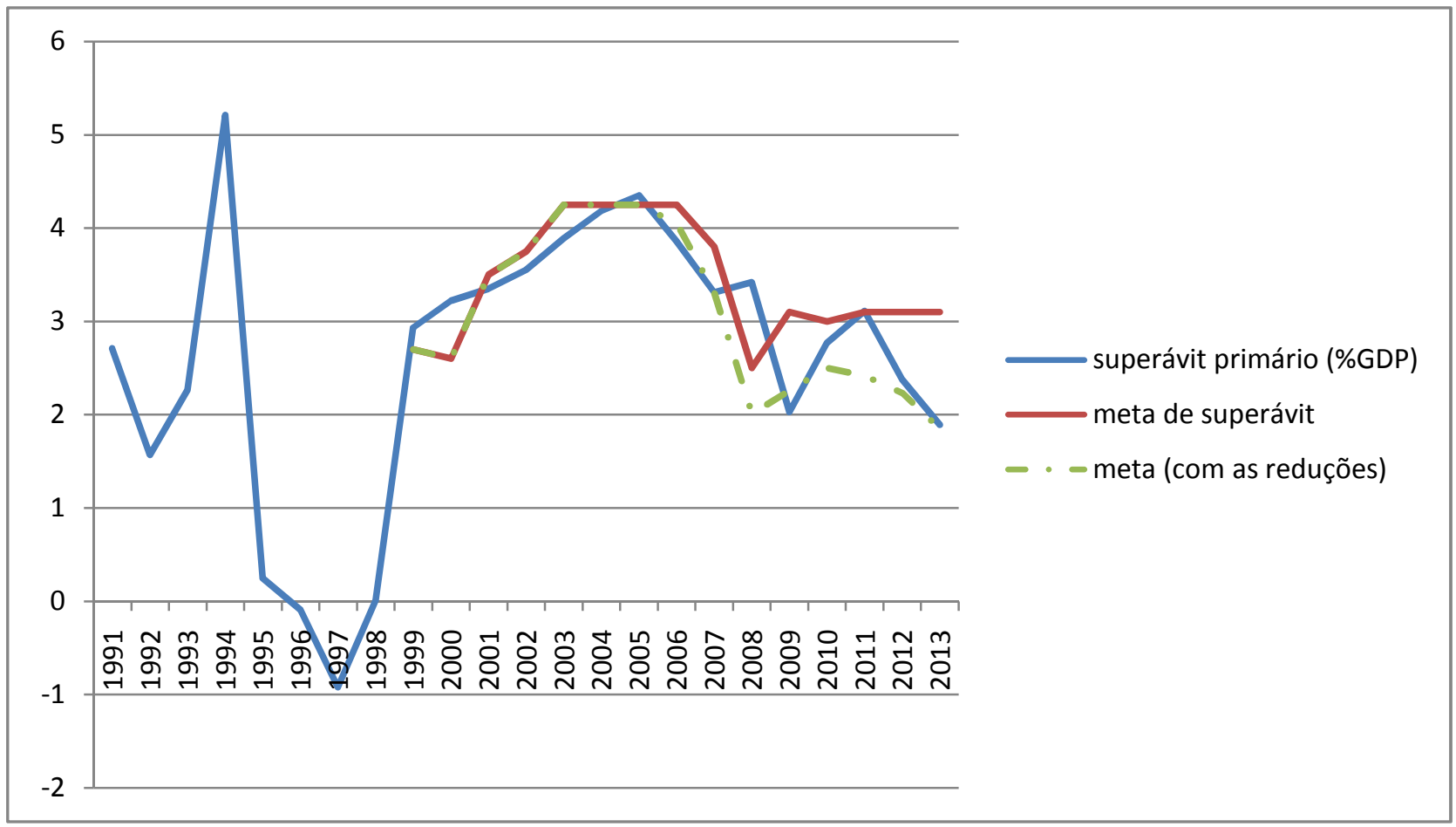

Gráfico 2: Superávit Primário e Metas de Superávit: 1991-2013. Fonte: Elaboração própria a partir de Giambiagi e BCB. ${ }^{149}$

\footnotetext{
${ }^{149}$ Para os dados do superávit primário entre 1991 e 2007 a pesquisa utilizou os dados apresentados por Giambiagi (2008, pp. 542-543). Para os dados do superávit primário entre 2008 e 2013, a pesquisa aproveitou os dados do Banco Central no documento Indicadores Fiscais (BRASIL, 2014a, p. 6).
} 
Quatro padrões podem ser observados no gráfico. Primeiro, antes de 1994, o setor público consolidado manteve superávits primários, mas em um ambiente macroeconômico insustentável. A hiperinflação explica o superávit primário antes de 1994 no país. ${ }^{150}$ O Brasil viveu um contexto de hiperinflação durante os últimos anos da década de 1980 e os primeiros anos da década de 1990. Em janeiro de 1994, por exemplo, a taxa anual de inflação superou $2700 \%$, conforme a medição oficial INPC/IBGE (BRASIL, 2014b).

O segundo padrão que pode ser notado no gráfico é a quase inexistência de superávits primários no período entre 1995-1998. Caso a hiperinflação não existisse antes de 1995, provavelmente o mesmo padrão seria encontrado para o período anterior, dada a existência do que os economistas chamam de imposto inflacionário. ${ }^{151}$

Finalmente, podem ser notados os dois padrões mais importantes do gráfico para esta pesquisa: (i) de 1999 (inclusive) em diante, o Brasil alcançou superávit primário em todos os anos; (ii) depois de 2006, o superávit primário foi reduzido de mais de $4 \%$ para menos de 2\%, no ano de 2013, sendo que a meta de superávit para 2014, com as reduções legais, é de $1,9 \%$. O que pode ajudar a explicar esses dois últimos padrões da política fiscal desde uma perspectiva de direito e macroeconomia?

Em relação à geração sucessiva de superávits primários, foi em 1998 que o governo federal anunciou o Programa de Estabilidade Fiscal, estabelecendo metas explícitas para o superávit primário para o ano de 1999, por meio da Medida Provisória $\mathrm{n}^{\mathrm{o}}$ 1.716/1998. Como se discutiu no capítulo 3 e no capítulo 1 , as metas de superávit primário sinalizam aos investidores que o Brasil está disposto a estabelecer uma rota supostamente sustentável para a relação entre dívida pública e PIB. ${ }^{152}$ Em 1998, além do estabelecimento de metas nominais para o superávit primário, o governo federal também já contava com novos instrumentos legais para perseguir essas metas: a lei que reestruturou as dívidas estaduais, sancionada em setembro de 1997, começou a impulsionar o superávit primário dos estados em 1998, como discutido na seção 4.1.; em 1999, o Executivo passou a mobilizar a desvinculação das receitas da União para geração dos superávits primários, como discutido na seção anterior. Em suma, a partir de 1999, o governo federal consolidava um novo regime jurídico para a política fiscal,

\footnotetext{
${ }^{150}$ Ver Bicalho e Issler in Bacha e de Bolle (2011, pp. 258-260).

151 Para definição do conceito, ver nota de rodapé 85 , do capítulo 3 .

${ }^{152} \mathrm{Na}$ realidade, a meta de superávit primário não necessariamente estabelece uma rota sustentável para a relação dívida pública/PIB. É possível ter superávits primários expressivos e mesmo assim ter uma elevação na relação entre dívida e PIB, a depender do nível de atividade econômica e do custo de rolagem da dívida.
} 
no qual ele teria ferramentas legais para perseguir e manter metas de superávits primários para o setor público consolidado.

Aliado a esse cenário doméstico, o acordo com o FMI celebrado em 1998 fez com que o Brasil assumisse o compromisso público de alcançar superávits primários expressivos. Na verdade, a primeira versão do acordo de outubro de 1998 previa metas relacionadas às necessidades de financiamento do setor público, que variam ao longo do ano, conforme as previsões sobre taxas de crescimento, arrecadação, despesas, juros e câmbio são alteradas. Ao contrário do superávit primário, metas que contemplem as necessidades de financiamento do setor público necessariamente provocam a estabilização da relação entre dívida pública e produto interno bruto. Porém, com a desvalorização do real em face do dólar e a elevação significativa das metas relacionadas às necessidades de financiamento, resultado da expressiva parcela da dívida pública que estava atrelada à moeda estrangeira em 1999, o Brasil pleiteou e conseguiu negociar com o FMI em 1999 a mudança do critério de mensuração de performance do acordo. A partir da segunda revisão do acordo, em maio de 1999, as metas seriam pré-fixadas e corresponderiam a promessas fixas de obtenção de superávit primário, definidas anualmente, ao invés de metas de acordo com as necessidades de financiamento do setor público, o que acabou sendo fixado em lei posteriormente, com a aprovação da Lei de Responsabilidade Fiscal. ${ }^{153}$

Além disso, caso a hipótese desta pesquisa esteja correta, não somente a manutenção de superávits primários a partir de 1999 pode ser mais bem compreendida, mas também mudanças eventuais na gestão da política fiscal ao longo desse período, como a ocorrida após 2006, podem ser analisadas a partir de uma nova perspectiva. Caso as regras jurídicas e sua interpretação administrativa tenham concentrado poderes fiscais no Executivo federal em um contexto de fortes influências internacionais, como se alega neste trabalho, a mudança de qualquer dessas variáveis pode ter um considerável impacto na gestão da política fiscal do setor público consolidado.

Sugere-se que esse foi justamente o caso em 2006, o que ajudaria a explicar a redução permanente das metas e dos superávits primários apresentados pelo setor público consolidado. Quatro elementos foram alterados nesse ano - e foram mantidos até o início de 2014, quando a análise desta pesquisa se encerra: na cúpula do Ministério da Fazenda, Antonio Palocci foi substituído por Guido Mantega; no Congresso, a base

\footnotetext{
${ }^{153}$ Ver, entre outros, Giambiagi e Além (2011).
} 
política de sustentação do Executivo foi substancialmente alterada; em âmbito internacional, em dezembro de 2005, o Brasil pagou antecipadamente as parcelas devidas pelo acordo stand-by celebrado com o FMI; ainda em âmbito internacional, a partir de 2006, o Brasil passou a ter uma dívida externa líquida negativa. Essas mudanças ilustram que tanto as elites políticas no Poder Executivo quanto as condições internacionais foram alteradas, o que pode facilitar a compreensão das mudanças na gestão da política fiscal.

A substituição de Antonio Palocci por Guido Mantega é o primeiro elemento que pode ajudar a contextualizar a mudança na gestão da política fiscal mensurada em termos de superávit primário e que talvez demonstre a importância de ideias econômicas das elites políticas na condução da política fiscal. ${ }^{154}$

Desde o início do governo Lula, ainda em 2003, Palocci representou o papel de um dos fiadores da política econômica do governo federal do Partido dos Trabalhadores junto ao mercado pela clara demonstração de sua vontade em dar continuidade ao projeto de política macroeconômica estabelecido a partir de 1999 no país, especialmente com a elevação de metas para o superávit primário. O documento Política Econômica e Reformas Estruturais, elaborado pelo Ministério da Fazenda em abril de 2003 e assinado por Antonio Palocci e sua equipe, é talvez uma das melhores expressões do projeto de continuidade da política econômica, mesmo após a mudança da Presidência em 2002. No tocante à política fiscal, o documento afirmava:

o novo governo tem como primeiro compromisso da política econômica a resolução dos graves problemas fiscais que caracterizam nossa história econômica, ou seja, a promoção de um ajuste definitivo das contas públicas. [...] uma das tarefas do governo é a execução de uma política fiscal sólida nos próximos anos que traga consistência de médio e longo prazo às contas públicas, e uma melhoria da qualidade do ajuste fiscal realizado nos últimos anos. Para isso, são necessárias medidas que produzam superávites primários, neste e nos próximos exercícios, suficientes pvara reduzir a relação dívida/PIB e, portanto, os gastos futuros com o serviço da dívida. Uma indicação clara de consistência das políticas na área fiscal contribuirá para a queda no

\footnotetext{
${ }^{154}$ Os próximos parágrafos deste capítulo podem ser interpretados como um esboço de um projeto de pesquisa que poderia ser aprofundado para compreender a gestão da política fiscal no Brasil nos anos recentes: uma análise sobre os atores que ocupam os postos-chaves da gestão econômica do país tais como definidos pelo regime jurídico da política fiscal. Para uma análise em sentido semelhante, ver: Loureiro, dos Santos, Gomide (2011) e Werneck in Bacha e De Bolle (2011, pp. 250-258).
} 
prêmio de risco do Brasil e do próprio custo da dívida doméstica e externa. (BRASIL, 2003, p. 8)

Ou seja, de acordo com o documento que anunciava as políticas econômicas a serem perseguidas no primeiro ano do novo governo, a política fiscal deveria se preocupar prioritariamente com a sustentabilidade da dívida pública e com a relação dívida/PIB. Segundo o documento, não havia espaço para qualquer alteração na política fiscal, a não ser para o aprofundamento do ajuste fiscal iniciado anos antes. Esse era o único mecanismo apto a contribuir com a credibilidade da política econômica brasileira em âmbito internacional. ${ }^{155}$ Nesse sentido, no ano de 2003, o governo elevou a meta de superávit de 3,5\% do PIB para 3,75\% do PIB.

Um segundo documento produzido pelo Ministério da Fazenda, em 2004, intitulado de "Reformas Microeconômicas e Crescimento de Longo Prazo" é ainda mais enfático ao sinalizar a continuidade da política macroeconômica iniciada em 1999, pelo menos no que diz respeito à política fiscal. Em primeiro lugar, o próprio título do documento já sugeria que as reformas incentivadas pelo governo federal seriam microeconômicas e não macroeconômicas. Em segundo lugar, no que diz respeito à política fiscal, o conteúdo do texto era focado na manutenção da sustentabilidade da dívida pública: "A sustentabilidade das contas públicas é o centro da política macroeconômica"; "A austeridade na administração das contas públicas pode ser verificada pelos resultados primário e operacional do setor público obtidos em 2003 e 2004”. (BRASIL, 2004, pp. 8 e 17).

O uso de palavras como "sustentabilidade" e "austeridade" não correspondia a uma tentativa de transmitir uma mensagem incongruente com os resultados alcançados pela política fiscal aplicada pelo país: a linha azul do gráfico apresentado acima demonstra que o superávit mensurado em proporção do PIB cresceu ininterruptamente

\footnotetext{
${ }^{155}$ Nesse sentido, não se constatam diferenças significativas em relação ao período anterior, apresentado no capítulo anterior. Não é por acaso que, à época, classificariam o governo iniciado em 2003 como "contraditório", pois, ao mesmo tempo em que acenava com mudanças em diversas áreas sociais, não efetivava qualquer modificação na política macroeconômica (BORGES NETO, 2003). Ou até mesmo "neoliberal", rótulo que era usado para expressar o quanto o governo do Partido dos Trabalhadores teria rompido com suas raízes de esquerda (PAULANI, 2008, p. 70). Paulani acrescenta, inclusive, que uma das principais razões pelas quais classificava o governo Lula como neoliberal decorria do modo de apresentação dos argumentos em favor da política econômica escolhida. De acordo com Paulani, o discurso do início do governo era o de "só há uma política macroeconômica correta e cientificamente comprovada: a política de matiz ortodoxo levada à frente por sua equipe econômica desde o início do governo. Como do ponto de vista macro (leia-se de manipulação das variáveis da demanda agregada) não há escolha, sustenta-se que o crescimento virá do rearranjo das condições de oferta (leia-se da política microeconômica), que consiste em 'melhorar o ambiente de negócios"” (ibidem, p. 70).
} 
entre 2003 e 2005: ele saiu de 3,55\% do PIB, em 2002, para 4,35\%, em 2005. A meta de superávit primário para os anos de 2004 e 2005 foi de 4,25\%. ${ }^{156}$

Talvez a melhor expressão da tendência de continuidade da política fiscal enquanto Antônio Palocci foi Ministro da Fazenda no Brasil, tenha sido a discussão proposta por alguns membros do governo federal a respeito da criação de uma regra de déficit nominal zero para a política fiscal em 2005. Essa regra demandaria superávits primários maiores do que os que estavam sendo obtidos pelo governo federal. Tanto quanto metas relacionadas às necessidades de financiamento do setor público consolidado, uma regra de déficit nominal zero implicaria necessariamente a estabilização da relação dívida pública/PIB.

Entretanto, pouco depois da nomeação de Guido Mantega, em 2006, a discussão perdeu força e foi completamente deixada de lado. ${ }^{157}$ Quando Guido Mantega foi nomeado Ministro da Fazenda, o Ministro das Relações Institucionais à época, Tarso Genro, afirmou que "acabou a era Palocci no Brasil", representante de "uma política econômica monetarista e conservadora". ${ }^{158}$ Embora publicamente Guido Mantega tenha continuado a defender que as metas de superávit primário eram "sagradas", o que se viu após sua ida ao Ministério da Fazenda foi uma modificação substantiva na gestão da política fiscal. $^{159}$

Ao lado da redução das metas de superávit primário, talvez a melhor expressão da "nova era" da política econômica seja a análise da quantidade de investimento em

\footnotetext{
${ }^{156}$ Em 2006 e 2007, as metas também foram de 4,25\% do PIB, mas nesses anos as reduções permitidas por lei já começaram a surtir efeito: em 2006, as exceções representavam 0,2\% do PIB; em 2007, 0,49\%, o que faz com que a linha azul do gráfico, representando o superávit primário, acompanhe as metas de superávit com as reduções permitidas em lei.

${ }^{157}$ À época, a Ministra da Casa Civil que substituíra José Dirceu, Dilma Rousseff, chegou a classificar a ideia de déficit zero de rudimentar, contribuindo para seu esquecimento (LOUREIRO, DOS SANTOS e GOMIDE, 2011, p. 70). Dilma Rousseff também é considerada por Loureiro, dos Santos e Gomide como responsável por essa mudança na política fiscal apontada aqui. Como esclarece Werneck: "A proposta acabou torpeada por uma coalização comandada pela então ministra Dilma Rousseff, coadjuvada por Guido Mantega, então presidente do BNDES. Classificada como rudimentar pela ministra-chefe da Casa Civil, a ideia foi deixada de lado quando Antonio Palocci teve de ser substituído por Guido Mantega no início de 2006" (Werneck in BACHA e DE BOLLE, 2011, p. 251). Ver também a referência à frase de Dilma Rousseff no portal de notícias <http://g1.globo.com/Noticias/Economia_Negocios/0,,AA1302888-9356,00-

LULA+AGORA+ACEITA+O+DEFICIT+ZERO.html> (último acesso em 9 de outubro de 2014).

158 A entrevista está disponível em: <http://www1.folha.uol.com.br/folha/brasil/ult96u86059.shtml> (último acesso em 9 de outubro de 2014).

${ }^{159}$ Os principais veículos de comunicação sempre entenderam que Mantega representava uma perspectiva de mudança da política econômica. Nesse sentido, reportagem da Folha de São Paulo, de 27 de março de 2006, explicava que "Guido Mantega, 56, enfrenta resistências de parte do mercado financeiro por conta de ideias consideradas fora da ortodoxia econômica". Quatro anos mais tarde, o Portal G1, apresentaria reportagem com o título: "Guido Mantega representa o "desenvolvimentismo" no governo", disponível em: $\quad$ <http://g1.globo.com/economia-e-negocios/noticia/2010/11/guido-mantega-representa-odesenvolvimentismo-no-governo.html> (último acesso em 9 de outubro de 2014).
} 
infraestrutura permitida como exceção ao cálculo do superávit primário. A exceção foi prevista inicialmente na Lei de Diretrizes Orçamentárias de 2006 com o nome de Plano Piloto de Investimento e foi indicada pela linha tracejada em verde no gráfico acima. Em valores, a exceção inicial prevista em 2006, no valor de $\mathrm{R} \$ 3$ bilhões, saltou para $\mathrm{R} \$$ 65,2 bilhões em 2013:

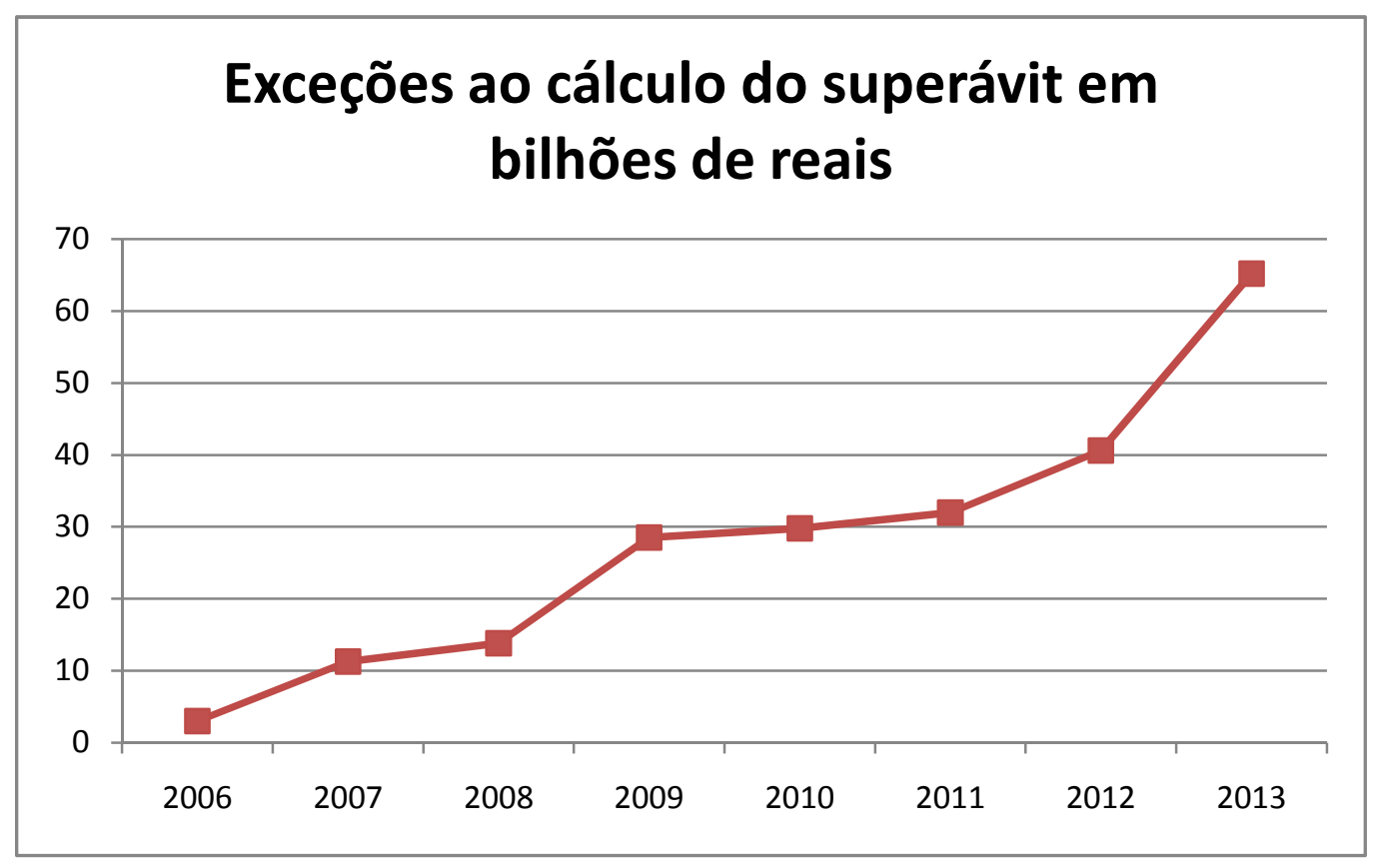

Gráfico 3: Exceções ao cálculo de superávit primário. Fonte: LDOs de 2006 a $2013^{160}$

Como se pode perceber tanto pelo tracejado verde como pelo traço vermelho no gráfico 2, um ano após Mantega ter assumido o Ministério da Fazenda, ao invés de superávits primários mais expressivos - como era de se esperar, dadas as discussões sobre déficit nominal zero incentivada por membros do governo no ano de 2005 - o que se viu foi o Ministro da Fazenda propor e manter uma redução permanente das metas para superávits primários. O Plano Plurianual de 2008-2011, por exemplo, previa a redução (se comparada à meta estabelecida para 2006) e manutenção do superávit primário do período em 3,8\%, além da expansão das exceções ao cálculo do primário, por meio do Projeto Piloto de Investimento e, posteriormente, dos investimentos em infraestrutura para o Programa de Aceleração do Crescimento (PAC). No período, a meta de 3,8\% não foi alcançada em nenhuma oportunidade.

\footnotetext{
${ }^{160}$ A prerrogativa de redução da meta de superávit primário pelo abatimento dessas despesas, contudo, não foi utilizada no ano de 2011.
} 
A crise econômica internacional do final dos anos 2000 parece ter incentivado a redução do superávit para o período entre 2007 e 2010. Embora até mesmo economistas ortodoxos pudessem defender a redução dos superávits primários durante a crise econômica internacional iniciada em $2008^{161}$, a manutenção de níveis mais baixos para as metas de superávit nos últimos anos sugere que a mudança na definição e na perseguição dos superávits não está conectada somente ao impacto da crise internacional. ${ }^{162}$ Após a implantação do novo regime jurídico da política fiscal, as ideias das elites políticas do poder executivo federal parecem constituir fator relevante na análise do quadro mais amplo da gestão da política fiscal no país. ${ }^{163}$

Além da mudança na cúpula da elite política responsável pelas tomadas das decisões centrais na gestão da política fiscal, o ano de 2006 também representou o momento no qual a relação entre o Executivo e o Legislativo foi alterada: de uma posição mais isolada, o Executivo passou a priorizar a formação de supermaiorias no Congresso (NOBRE, 2013; SINGER, 2012). Nesse caso, embora o contra-factual seja impossível de ser realizado, talvez até mesmo a manutenção de um Ministro da Fazenda favorável a superávits mais robustos não fosse suficiente para impedir a transformação da política fiscal por razões ligadas à governabilidade política desejada pela Presidência. Afinal, a mudança de base governista no Congresso representa uma significativa mudança na elite política do governo federal e, para garantir maiorias no Congresso, a redução do superávit primário pode ser bem-vinda. Ela pode ser mobilizada para obter o apoio político de congressistas, via aumento da aprovação de emendas individuais que

\footnotetext{
${ }^{161}$ O que não é nada claro no caso brasileiro. Goldfajn e Parnes in Bacha e Goldfajn (2008), por exemplo, defenderam que o uso da política fiscal como política anticíclica não era a melhor solução para o país, no contexto da crise. Em primeiro lugar, eles argumentavam que o uso da política fiscal deveria ser precedido pelo uso da política monetária e dependeria da intensidade do impacto da crise mundial no país. Os autores ainda sugeriam que as contraindicações no uso da política fiscal, tais como a possibilidade de elevar os gastos correntes do governo e a perspectiva de redução da arrecadação tributária no futuro, podiam superar seus benefícios de curto prazo.

${ }^{162}$ Essa é a hipótese de Werneck: "Qual foi o efeito mais grave da crise no Brasil? [...] [o que] chegou ao país como verdadeiro vagalhão foi a onda de afrouxamento generalizado de restrições orçamentárias que veio das economias avançadas. Pode-se dizer que esse desdobramento da crise foi até festejado pelo governo. A crise lhe deu a oportunidade que em condições normais jamais teria. Permitiu, afinal, legitimar mudanças bruscas no regime fiscal e nas relações entre o Estado e a economia" (in BACHA e DE BOLLE, 2011, p. 252). A análise de Barbosa e Souza (2010) também corrobora essa hipótese. Após demonstrar que os argumentos econômicos sobre o governo Lula se dividiam entre os de matiz neoliberal e os desenvolvimentistas, os autores argumentam que o segundo governo Lula "optou mais claramente por uma política econômica desenvolvimentista", com redução no resultado primário, "elevação substancial no salário mínimo; aumento no investimento público; e reestruturação de carreiras e salários dos servidores públicos" (BARBOSA e SOUZA, 2010, p. 14).

${ }^{163}$ É interessante notar que essa valorização do papel das ideias é também reconhecida na literatura internacional sobre regras fiscais, ainda que de modo controverso, como discutido no capítulo 1.
} 
podem ser apresentadas no momento da elaboração orçamentária, por exemplo. ${ }^{164}$ Esse argumento sugere que não somente a ideologia, mas também a estrutura da relação entre Presidente e Congresso pode ser central na compreensão da gestão fiscal de acordo com o atual regime jurídico da política fiscal.

Os resultados da política fiscal nos anos 2000 também indicam que fatores internacionais podem afetar a gestão da política. Foi em dezembro de 2005 que o país pagou adiantadamente as parcelas devidas pelo acordo stand-by com o FMI. A partir de 2006, o país passou a ter uma dívida externa líquida negativa, como mostra o gráfico abaixo. Tais datas coincidem com o início da redução das metas para superávit primário discutidas acima, o que pode ser, por exemplo, resultado da menor exposição do governo federal a riscos externos.

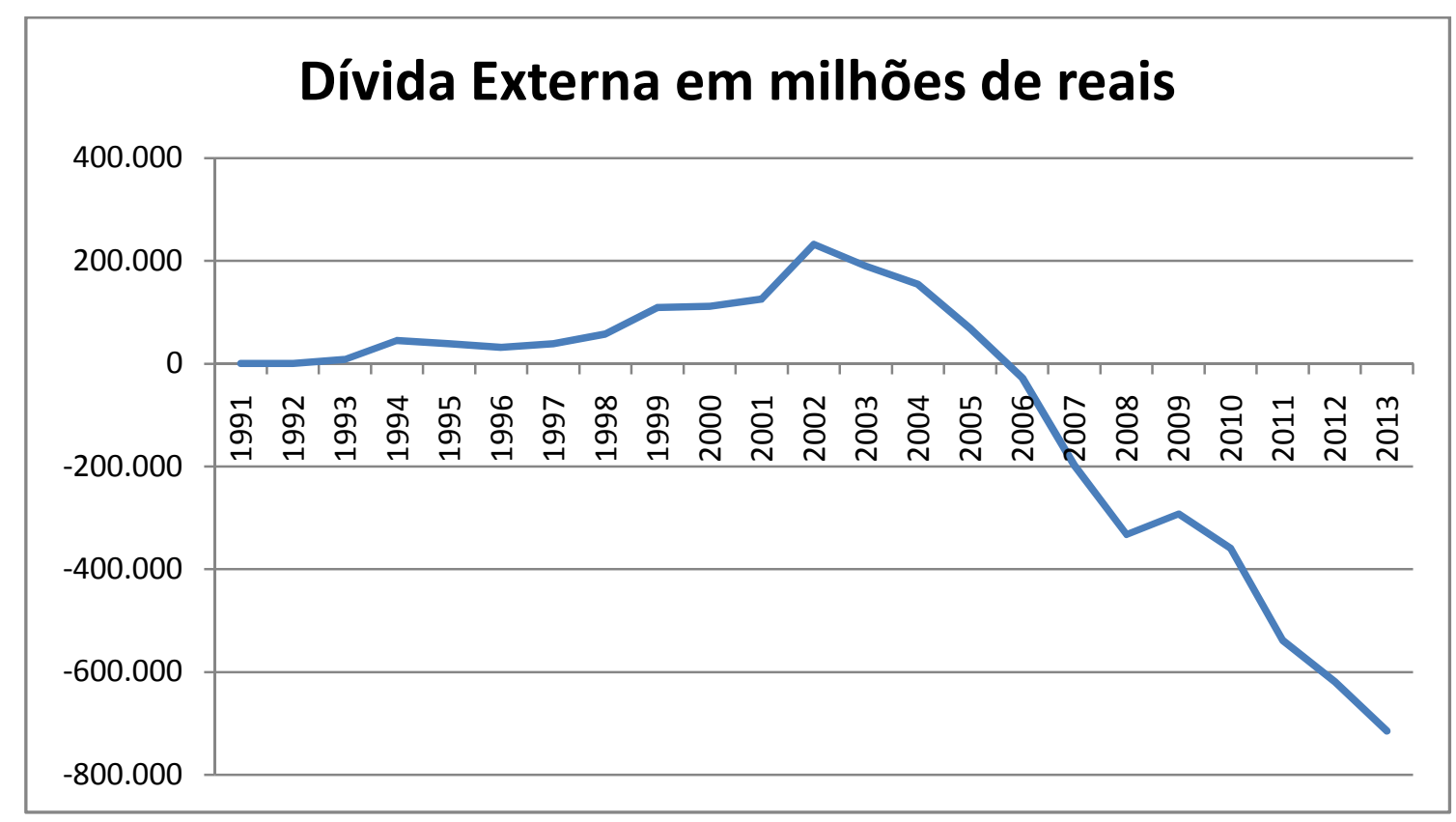

Gráfico 4: Dívida externa líquida do setor público. Fonte: STN, medido a partir do dia 1/12, de cada um dos anos que compõem a série mensal produzida pela Secretaria. ${ }^{165}$

O gráfico acima demonstra como o ano de 2006 foi um ano de transição para o setor público não-financeiro, que inclui as administrações diretas e indiretas dos

\footnotetext{
${ }^{164}$ Este é somente um exemplo, que pode ser empiricamente avaliado, embora não se conheça nenhum estudo sobre o tema. Outros exemplos mais difíceis de serem avaliados - mas plausíveis - são, por exemplo, o aumento de recursos para políticas públicas ligadas a Ministérios, Secretarias, Estados e municípios controlados por partidos da base aliada que deem apoio aos projetos mais sensíveis do governo federal. Deve-se lembrar que uma redução de $2 \%$ no superávit, em valores atuais, representa um valor em torno de R \$ 100 bilhões de reais (considerando o PIB no valor de US\$2,253 trilhões).

165 A série histórica para a dívida externa líquida está disponível em: <http://www3.tesouro.fazenda.gov.br/series_temporais/principal.aspx\#ancora_consulta> (último acesso em 12 de outubro de 2014).
} 
governos federal, estaduais e municipais, o Banco Central, a Previdência Social e as empresas estatais não financeiras, com exceção da Petrobrás a partir de 2001, no que diz respeito à dívida líquida do setor público externa.

Em síntese, (i) oportunidades políticas advindas de alterações nas condições internacionais; (ii) a modificação das condições políticas internas, com a mudança da base aliada no Congresso; (iii) e a entrada de uma nova elite no Executivo federal, com ideias econômicas distintas das anteriores sobre política fiscal, podem auxiliar a compreensão da mudança da gestão da política fiscal na última década. Esses elementos ganham força explicativa no contexto da aprovação do regime jurídico da política fiscal, que concentrou prerrogativas fiscais no Executivo federal e criou limites legais para a gestão da política.

Essa análise sobre a política fiscal do setor público consolidado conduz a duas diferentes conclusões. Em primeiro lugar, em direção oposta ao que foi sugerido pela literatura apresentada no início desta seção, é possível defender que talvez exista uma margem de manobra para o governo federal gerir autonomamente a política fiscal no país. Ainda que depois da consolidação do regime jurídico para a política fiscal o setor público sempre tenha obtido superávits, o que indica que provavelmente não existe absoluta discricionariedade do governo federal, também parece ser possível defender que decisões políticas discricionárias têm influenciado a gestão da política fiscal.

Em segundo lugar, essa discricionariedade parece ter sido mais relevante no contexto de existência dessas regras fiscais que organizam e centralizam a gestão das finanças públicas nas mãos do Executivo federal do que anteriormente. Discricionariedade, aqui, deve ser entendida como a possibilidade de decisão política das metas a serem perseguidas - portanto, a escolha de uma alternativa em detrimento de outras ocorreria de acordo com os interesses, ideologia e desejos dos atores responsáveis pela decisão - em contraposição a uma situação na qual a decisão é vinculada.

Como mero exemplo da existência dessa discricionariedade, é importante retomar controvérsias públicas recentes sobre o tema da política fiscal. Em entrevista recente, o pesquisador do Instituto Brasileiro de Economia (IBRE) da Fundação Getúlio Vargas (FGV), Samuel Pessoa, alegou que "houve uma redução forte e prematura do superávit primário." O pesquisador argumentou que "até 2008, os juros estavam caindo e a inflação estava na meta. Mas em 2009, Mantega e sua equipe viram uma oportunidade de mudar a política econômica, e aí entra a questão ideológica de qual 
livro de economia você estudou" (grifo nosso). ${ }^{166}$ Do lado do governo, o Secretário do Tesouro Nacional, Arno Augustin, defendeu publicamente o uso da política fiscal como política anticíclica em face da crise internacional: " $O$ conjunto dos benefícios, de incentivos que a economia precisou em função da crise internacional, em razão desse momento de menor crescimento, já fizemos e estamos, para este ano, com um planejamento de não haver novos processos de incentivos à economia" (grifo nosso). ${ }^{167}$ A controvérsia entre as pessoas que acham que houve redução prematura do superávit e aqueles que acreditam que a mudança foi necessária, dada a crise internacional, serve para demonstrar que há atualmente uma explícita disputa a respeito da condução da política fiscal no país. De um lado, estão aqueles que defendem o aumento do superávit primário; de outro, aqueles que defendem sua redução ou manutenção nos patamares atuais.

Não interessa discutir nesta dissertação o mérito dos posicionamentos econômicos de cada um dos interlocutores na controvérsia. $\mathrm{O}$ debate público envolve diversos aspectos da política econômica praticada pelo governo que esta pesquisa não pretendeu analisar. Para esta dissertação, a controvérsia é útil porque permite demonstrar como o regime criado a partir de 1999 possibilita decisões políticas a respeito da gestão da política fiscal: o que os atores envolvidos no debate público indicam é que a decisão a respeito do que fazer na política fiscal poderia ter sido diferente, nos últimos anos. Há opções distintas que podem ser adotadas por diferentes agentes públicos.

A análise superficial da controvérsia apresentada acima também é suficiente para sugerir como o direito contribuiu para estruturar a própria disputa sobre os limites da gestão da política físcal no país. Hoje, regras jurídicas delimitam um campo de disputa sobre a política fiscal no interior do qual diferentes posições podem ser encontradas. Perguntas como "as metas de superávit deveriam ser elevadas ou reduzidas pelo governo?", “a meta de superávit é perseguida adequadamente?” e “o governo

\footnotetext{
${ }^{166}$ A entrevista está disponível em: <http://exame.abril.com.br/economia/noticias/brasil-escolheu-crescerpouco-diz-samuel-pessoa> (último acesso em 20 de agosto de 2014). A crítica de Samuel Pessoa é compartilhada por outros economistas. Ver, por exemplo, textos de Mansueto Almeida, que chegou a afirmar: "Se o governo tivesse mantido nos últimos cinco anos a política do período Malan e Palocci estaríamos em uma situação muito melhor e pagando juros menores. Mas a equipe econômica tentou reinventar a roda e criar uma "nova matriz econômica'." Ver: <http://mansueto.wordpress.com/2014/06/22/tudo-esta-bem-na-questao-fiscal-sera/> (último acesso em 20 de agosto de 2014).

${ }^{167}$ Ver Conjuntura Econômica, abril de 2014, "Esperança no futuro". Ver, ainda, os textos críticos à política macroeconômica praticada pelo governo, de Bresser-Pereira (2013), Saad Filho e Morais (2011), José Luiz Oreiro (2014); e De Paula e Modenesi (2013).
} 
deveria perseguir metas de superávit ou outras metas?", todas presentes explícita ou implicitamente no debate acima apresentado, expressam como a previsão legal do estabelecimento de metas de resultado primário para o governo federal estrutura o debate público. A discussão sobre o exercício dessa discricionariedade nos leva à questão sobre a transparência na gestão da política fiscal, o que será feito na próxima seção, que encerra este capítulo.

\subsection{Novos mecanismos de transparência e de prestação de contas}

As controvérsias recentes sobre política fiscal no país também têm se refletido na avaliação do grau de transparência da sua gestão pelo governo federal. Críticos do governo acusam o Ministério da Fazenda de "contabilidade criativa" para cumprimento das metas de superávit. ${ }^{168} \mathrm{O}$ governo federal, por sua vez, rebate as críticas afirmando que respeita todas as exigências legais e os parâmetros internacionais no cálculo do superávit. $^{169}$

Para os fins desta pesquisa, importa analisar quais são os critérios usualmente utilizados no debate público sobre transparência e prestação de contas (accountability) da política fiscal. Cumpre verificar também se e como eles estão relacionados com as transformações e com a implantação do regime jurídico da política fiscal. Na realidade, como indicado desde o capítulo 1 desta dissertação, a análise deste âmbito da política fiscal é essencial em qualquer pesquisa de direito e macroeconomia porque ela permite compreender como os próprios atores interpretam a legitimidade democrática da gestão da política fiscal.

Os mecanismos de transparência aprovados pela Lei de Responsabilidade Fiscal, apresentados no capítulo 2, como a publicação periódica de relatórios e o uso de um sistema integrado e informatizado sobre administração financeira, representam diferentes mecanismos de transparência do poder público sobre a política fiscal. A maior parte deles está relacionada à liberação de informações para o público, mas há

\footnotetext{
168 Ver Werneck in Bacha e De Bolle (2011, pp. 252 - 255). Ver ainda, além da entrevista de Samuel Pessoa mencionada na nota 38, a entrevista de José Roberto Afonso, ex-diretor do BNDES, para o jornal Valor Econômico: <http://www.valor.com.br/brasil/3160846/credibilidade-fiscal-depende-de-menos-criatividade-dizeconomista> (último acesso em 15 de agosto de 2014).

169 Ver entrevista de Guido Mantega: <http://www1.folha.uol.com.br/mercado/2013/04/1257709-naohouve-alquimia-diz-mantega-sobre-contabilidade-criativa-em-2012.shtml> (último acesso em 15 de agosto de 2014). Ver também entrevista de Arno Augustin, mencionada na nota 166.
} 
também dispositivos que dizem respeito à participação do público no processo de elaboração orçamentária.

No âmbito da transparência da política fiscal, talvez o aspecto mais relevante da implementação do seu regime jurídico seja a exigência de publicação de metas, que determinam a condução da política e balizam o debate público ao redor do tema, bem como a publicação quadrimestral de relatório de cumprimento de metas, produzido pelo Ministério da Fazenda e pelo Ministério do Planejamento, Orçamento e Gestão. Desde 2001, o Executivo Federal tem apresentado e disponibilizado o relatório no sítio eletrônico da Secretaria do Tesouro Nacional. ${ }^{170} \mathrm{O}$ relatório é discutido logo após sua elaboração, em audiência pública na Comissão Mista de Planos, Orçamentos Públicos Fiscalização do Congresso Nacional.

Para além da importância do estabelecimento das metas fiscais e da produção dos relatórios relativos ao seu cumprimento na prestação de contas entre os poderes, a controvérsia mencionada no início desta seção demonstra como esses elementos são relevantes para permitir a existência de um controle social das práticas fiscais do governo federal. A partir das metas estabelecidas na Lei de Diretrizes Orçamentárias e dos relatórios que justificam como essas metas são perseguidas pelo governo, o debate público sobre a política fiscal pode ser desenvolvido com base em uma gramática comum de metas, ferramentas e metodologia - ainda que seja para criticar as propostas oficiais. Estudos futuros poderiam tentar aprofundar a avaliação sobre como o debate público ao redor da política fiscal tem evoluído, partindo da análise da relação entre Legislativo e Executivo no estabelecimento das metas fiscais e na apresentação dos relatórios de cumprimento, bem como do estudo da dinâmica de interação entre sociedade e Estado.

A implementação do novo regime jurídico da política fiscal também se destaca pelo respeito à determinação de produção dos relatórios resumidos da execução orçamentária e de gestão fiscal. O relatório resumido da execução orçamentária é produzido no prazo de trinta dias após o fim de cada bimestre e abrange os órgãos da administração direta e indireta que recebem recursos do orçamento fiscal e do orçamento da seguridade social. ${ }^{171}$ Por sua vez, o relatório de gestão físcal tem como

\footnotetext{
170 Até hoje, 40 relatórios foram produzidos. Todos eles estão disponíveis no sítio eletrônico: <http://www.tesouro.fazenda.gov.br/relatorio-de-cumprimento-de-metas> (último acesso em 9 de setembro de 2014).

${ }^{171}$ Os relatórios estão disponíveis em: <http://www.tesouro.fazenda.gov.br/-/relatorio-resumido-deexecucao-orcamentaria> (último acesso em 9 de setembro de 2014).
} 
objetivo o controle e a publicidade do cumprimento de limites percentuais da receita corrente líquida estabelecidos pela Lei de Responsabilidade Fiscal relativos a despesas com pessoal, dívida consolidada líquida, concessão de garantias e contratação de operações de crédito. ${ }^{172}$

Durante a década de 2000, no âmbito da publicação de informações sobre gastos públicos do governo federal, destaca-se também a criação do Portal da Transparência, em 2004, ainda que essa iniciativa não tenha decorrido diretamente de qualquer determinação dos princípios e regras discutidos no capítulo $2 .^{173} \mathrm{O}$ Portal da Transparência publica diariamente informações sobre gastos públicos, incluindo aquelas sobre execução orçamentária e financeira, no âmbito do Poder Executivo Federal, e dos salários das servidoras e dos servidores públicos, entre outras informações. Trata-se de uma das principais ferramentas de transparência dos gastos públicos do governo federal (LOUREIRO, TEIXEIRA e PRADO, 2008).

No âmbito das próprias regras e princípios jurídicos da política fiscal, uma importante alteração ocorreu a partir da aprovação da chamada Lei da Transparência (Lei Complementar $n^{\circ}$ 131) em 2009. Essa Lei alterou a Lei de Responsabilidade Fiscal justamente no artigo sobre transparência da política fiscal, passando a exigir dos órgãos públicos, incluindo estados e municípios, a publicação em tempo real de dados relativos à execução orçamentária e aos gastos públicos.

Estudos demonstram que os entes subnacionais têm publicado seus dados de diferentes maneiras e nem sempre cumprem com as determinações legais relativas à transparência. O Instituto de Estudos Socioeconômicos, por exemplo, elaborou um ranking a partir das informações fiscais disponibilizadas na internet pelas capitais brasileiras entre $1^{\circ}$ de dezembro de 2010 e 18 de fevereiro de 2011 (INESC, 2011) e concluiu que a maior parte das capitais somou uma pontuação intermediária na avaliação do respeito às diversas variáveis, embora duas delas não tenham pontuado em qualquer dos critérios. ${ }^{174}$ Ou seja, há uma discrepância entre a previsão legal sobre

\footnotetext{
172 Os relatórios do governo federal estão disponíveis em: <http://www.tesouro.fazenda.gov.br/web/stn//relatorio-de-gestao-fiscal> (último acesso em 9 de setembro de 2014)

${ }^{173}$ Ver: <http://www.portaltransparencia.gov.br/> (último acesso em 9 de outubro de 2014).

${ }^{174}$ A avaliação considerou 58 variáveis em 6 dimensões: elaboração orçamentária (2 variáveis); acesso à legislação orçamentária (4); conteúdo da legislação (17); execução orçamentária (28); execução orçamentária do Legislativo (5) e avaliação (2) (INESC, 2011, p. 7). A pesquisa concluiu, ainda: "é preciso esclarecer que o estabelecimento de um ranking não é o objetivo do estudo. A ordem no índice poderia facilmente ter sido outra (ou ter sido alterada) caso algumas prefeituras tivessem certas informações orçamentárias atualizadas nos seus sites. O escopo é alertar o quanto as capitais estão distantes da excelência no que se refere à transparência do ciclo orçamentário. Neste sentido, os resultados antecipam o cenário de "Dante", que certamente seria encontrado se o corte no universo de
} 
publicação de dados na internet e o cumprimento desses dispositivos pelas capitais brasileiras. ${ }^{175}$ Loureiro, Teixeira e Prado partem de metodologia distinta, mas chegam a resultados semelhantes quanto às capitais, embora o caso dos estados seja melhor (2008, p. 112). ${ }^{176}$

O papel dos Tribunais de Contas na implementação do regime jurídico da política fiscal também deve ser destacado, em especial por conta das previsões da Lei de Responsabilidade Fiscal que fortaleceram sua função como órgão de controle. A aprovação anual das contas do governo, a partir de 2000, inclui seções de discussão sobre a implementação da Lei de Responsabilidade Fiscal, a evolução da dívida pública e a gestão fiscal do setor público consolidado, inclusive quanto ao cumprimento das metas fiscais. Neste âmbito de prestação de contas da gestão da política fiscal, a análise do resultado final dos Relatórios sobre as Contas do Governo da República demonstra que o TCU tem adentrado no mérito da discussão sobre política fiscal e transparência da gestão fiscal. O relatório mais recente produzido pelo órgão é a melhor expressão dessa disposição do TCU, ao concluir:

As metas fiscais, especialmente a de resultado primário, servem para dar confiança à sociedade de que o governo garantirá as condições necessárias à estabilidade econômica. Apesar disso, o acompanhamento e o controle do resultado primário pretendido e realizado pela União têm-se tornado verdadeiros desafios aos órgãos de fiscalização e à sociedade em geral. Isso porque, ao longo dos últimos anos, mudanças metodológicas e transações atípicas cada vez mais complexas vêm contribuindo para reduzir a transparência e dificultar o entendimento sobre que superávit primário o Governo Federal de fato tem perseguido. A Lei de Responsabilidade Fiscal (LRF) previu o estabelecimento de uma metodologia oficial para apuração do resultado primário da União e a instituição de um Conselho de Gestão Fiscal para acompanhar e avaliar a política e a operacionalidade da gestão fiscal, com foco na eficiência e na

municípios analisados fosse expandido de modo a abranger cidades que estão à margem do poder político e econômico nos estados." (INESC, 2011, p.12)

${ }^{175}$ Beghin e Zigoni (2014) criaram recentemente um ranking dos Portais de Transparência classificando 29 sítios eletrônicos sobre recursos públicos, 27 sítios das capitais dos Estados e do Distrito Federal, um do governo federal, além do portal do Senado Federal. Os critérios para elaboração do ranking variaram de acordo com os oito princípios de dados abertos, tais como definidos pelo Open Data Handbook. O resultado demonstra que expressiva parte das capitais também não cumpre com as determinações legais relativas a dados abertos.

${ }^{176}$ Embora, à época da elaboração do texto dos autores, em 2008, a Lei da Transparência não tivesse sido aprovada. 
transparência. Contudo, passados quatorze anos desde a edição da LRF, não foi criada a referida metodologia, tampouco o mencionado conselho. ${ }^{177}$

Em outras palavras, o relatório sobre as contas de 2013 criticou a atuação do governo federal na perseguição da meta de superávit primário e na transparência com que tal meta foi alcançada, em sentido semelhante às discussões sobre contabilidade criativa apresentadas no início desta seção. O TCU não discutiu o número da meta do primário - ou seja, se a meta deveria ser maior ou menor do que o estipulado pelo governo -, mas os meios pelos quais a meta definida foi alcançada. Ainda assim, o órgão passou a discutir aspectos centrais da política fiscal praticada pelo governo.

Nesse mesmo relatório, por exemplo, o TCU discutiu as medidas pelas quais o superávit do ano de 2013 foi alcançado, enfatizando, entre outras, a importância do contingenciamento dos recursos praticado por meio de decreto e o aumento contínuo do montante de despesas inscritas em restos a pagar. Sobre o aumento contínuo das despesas inscritas em restos a pagar, o órgão observou que esse "fato que deve ser visto com atenção, pois, muito embora essas despesas não tenham impacto direto no resultado primário apurado [...] indicam um potencial desembolso futuro" (TCU, 2014, p. 213). Não é por acaso que a conclusão da passagem acima mencionada do relatório do TCU criticou a ausência de metodologia oficial de apuração do resultado primário e da demora na criação do Conselho de Gestão Fiscal: uma metodologia oficial estabeleceria explicitamente regras e limites para operações do governo que buscassem modificar de modo supostamente artificial o alcance das metas; e um Conselho de Gestão Fiscal se dedicaria exclusivamente a controlar a gestão da política fiscal e a verificar o respeito aos critérios metodológicos estabelecidos.

Como se percebe, o estabelecimento de metas para o resultado primário do governo, a exigência de publicação de metas fiscais, a previsão de elaboração de relatórios e o controle da execução da política pelo TCU são mecanismos que efetivamente permitem o maior controle social sobre a gestão da política fiscal. Ao mesmo tempo, essas iniciativas tendem a estruturar o debate público em torno da política fiscal. Ou seja, esses mecanismos de transparência podem ter a característica paradoxal de fazer com que as informações que se tornam públicas a respeito da política

\footnotetext{
${ }^{177}$ Disponível em:

<http://portal2.tcu.gov.br/portal/page/portal/TCU/comunidades/contas/contas_governo/Contas2013/index .html> (último acesso em 25 de setembro de 2014)
} 
fiscal - metas e relatórios, por exemplo - determinem a discussão pública sobre o tema, enquanto outras questões que poderiam ser discutidas em torno da questão sejam deixadas de lado ou simplesmente ignoradas. Isso é o que parece ocorrer na discussão sobre superávits primários apresentada acima.

Como se demonstrou ao longo dos capítulos anteriores, a discussão em torno de superávit primário se relaciona prioritariamente com a estabilidade da relação dívida pública/PIB e não com outros elementos que também poderiam ser perseguidos via política fiscal, como aumento do investimento público em áreas sociais, a garantia do emprego e a aceleração do crescimento. Nesse contexto, talvez seja possível defender que o regime jurídico da política fiscal esteja estimulando um debate público orientado prioritariamente para questões de sustentabilidade da dívida pública, em detrimento de outras opções para a política físcal. O debate público orientado a questões de sustentabilidade da dívida pública inclusive ajudaria a compreender as razões pelas quais certos teóricos tendem a pensar que o regime fiscal iniciado a partir de 1999 bloqueou outras opções de política macroeconômica para a política fiscal.

É também a partir desse contexto que talvez possam ser interpretadas iniciativas de atores da sociedade civil e de alguns parlamentares que pressionam pela aprovação de leis de responsabilidade social e pela ampliação de espaços participativos na elaboração e execução orçamentária em âmbito federal.

A criação de metas sociais que vinculariam as decisões fiscais, embora não constituam mecanismo novo (a exemplo da vinculação constitucional de receitas para educação e saúde), pode representar uma maneira de inclusão de outros objetivos não relacionados à sustentabilidade da dívida pública na discussão específica sobre política fiscal. Duas diferentes propostas se destacam, nesse sentido: o projeto de lei complementar que altera dispositivos da Lei de Responsabilidade Fiscal apresentado pelo Fórum Brasil de Orçamento, em 2006; o projeto de lei do Senado n 205, de 2001, de autoria da à época Senadora Marina Silva.

Os dois projetos que modificam a Lei de Responsabilidade Fiscal justificam sua criação pela ênfase dada por ela para a obtenção de metas para a política fiscal, em detrimento de investimentos públicos e gastos com políticas sociais. A Senadora Marina Silva argumentava na justificativa de seu projeto de lei que:

Embora não deva haver dúvidas quanto à necessidade de que sejam estabelecidas regras para a gestão fiscal, tão ou mais importante que a "quantidade" dos dispêndios públicos é a "qualidade" desses gastos. 
Não fora assim, um governante que despendesse o tempo de seu mandato apenas cumprindo metas de resultado entre receitas e despesas e nada realizasse em proveito do desenvolvimento social poderia, sob a ótica da "quantidade" e dos limites dos gastos públicos, vir a ser considerado um administrador competente; o que, convenhamos, desnaturaria todos os princípios que devem presidir as políticas públicas. Nesse sentido, sem prejuízo das conquistas que se poderá extrair da nova lei, é imprescindível agregar ao conceito da responsabilidade fiscal a exigência da responsabilidade social. (BRASIL, 2001, p. 3)

Na prática, o projeto de lei do senado propôs a modificação do Conselho de Gestão Fiscal previsto na Lei de Responsabilidade Fiscal, para prevê-lo como Conselho de Gestão Fiscal e Responsabilidade Social. O Conselho teria atribuição para acompanhar e avaliar a consecução de metas de desenvolvimento social e seria composto por um representante de cada poder federal, três representantes dos estados, quatro de municípios, um representante do Ministério Público da União, dois dos Ministérios Públicos dos Estados e seis representantes de entidades da sociedade civil, de âmbito nacional. As metas de desenvolvimento social que seriam acompanhadas e avaliadas estariam relacionadas à criação do Índice Brasileiro de Responsabilidade Social, também prevista pela proposta de lei. O Índice, por sua vez, seria composto de indicadores de resultados, esforços e participação social, especialmente nas áreas de educação, saúde, segurança pública, desenvolvimento urbano, gestão ambiental, assistência social, esporte e lazer, distribuição de renda e finanças públicas. A proposta de lei, contudo, foi arquivada em 2011, após parecer pela aprovação na forma do substitutivo do Senador Pedro Simon, na Comissão de Constituição, Justiça e Cidadania. $^{178}$

Cinco anos após a apresentação do projeto de lei do senado, em 2006, 48 organizações, fóruns e movimentos sociais ${ }^{179}$ apresentaram a sugestão de projeto de lei de $n^{\circ}$ 210, de 2006, no âmbito da Comissão de Legislação Participativa, da Câmara dos

\footnotetext{
178 Após ter sido aprovado na Comissão de Constituição e Justiça, o Projeto de Lei do Senado foi remetido para Comissão de Assuntos Econômicos, sob a relatoria do Senador Eduardo Suplicy. Não parece ter havido apoio político para tramitação do projeto, que foi arquivado após o termino da sessão legislativa, nos termos do artigo 351 do Regimento Interno do Senado.

${ }^{179}$ As organizações, fóruns e movimentos se reuniram no âmbito do Fórum Brasil de Orçamento (FBO), criado em 2002, enquanto espaço de articulação política, sem estatuto jurídico. Por isso, a apresentação da documentação do projeto de lei ficou a cargo do Instituto de Estudos Socioeconômicos - INESC.
} 
Deputados. ${ }^{180}$ A proposta modifica substantivamente a Lei de Responsabilidade Fiscal, para prever, por exemplo, que não serão objeto de contingenciamento despesas referentes ao cumprimento de metas sociais selecionadas e ressalvadas pela Lei de Diretrizes Orçamentárias. A proposta também emenda a regra de apresentação quadrimestral do Relatório de Gestão Fiscal para prevê-lo como Relatórios de Gestão Fiscal e de Gestão Social. O Relatório de Gestão Social conteria o demonstrativo da execução de metas sociais selecionadas, apresentação da metodologia de apuração dos indicadores e metas sociais definidas, demonstrativo da execução das metas, justificativa para avançar nos limites, entre outros. Na justificativa de apresentação da sugestão, argumentou-se:

O FBO avançou na discussão de uma proposta que modificasse a Lei de Responsabilidade Fiscal no intuito de permitir que a responsabilidade social fosse colocada, no mínimo, em pé de igualdade com a responsabilidade Fiscal. Era imperativo modificar mecanismos previstos na LRF que levavam os administradores a cuidar somente do ajuste das suas contas em detrimento do desenvolvimento e da justiça sociais. Em muitos casos, a LRF tem servido até de desculpa para que os gestores se eximam de suas responsabilidades de cumprir preceitos constitucionais de garantia de direitos dos cidadãos e cidadãs brasileiras (BRASIL, 2006, p. 13)

Como se percebe, o que motivou tanto a proposta do projeto de lei do Senado como a sugestão do FBO foi a interpretação de que o atual regime jurídico da política fiscal daria indevida ênfase às metas fiscais, em detrimento de metas sociais. A sugestão de projeto de lei ${ }^{\circ}$ 210/2006 do FBO deu origem ao Projeto de Lei Complementar $n^{\circ}$ 264/2007, depois da realização de audiência pública no dia 10 de setembro de 2007 , na Comissão de Legislação Participativa, formalmente apresentado pela Deputada Luiza Erundina. O projeto de lei complementar $n^{\circ}$ 264/2007 foi apensado a outro, o projeto de lei complementar de $\mathrm{n}^{\mathrm{o}} 353 / 2006 .^{181}$ A última tramitação do projeto de lei

\footnotetext{
${ }^{180}$ Desde 2001, os membros da Comissão recebem propostas de iniciativa popular e, se aprovadas, as encaminham à Mesa Diretora da Câmara de Deputados como projetos de lei.

${ }^{181}$ O Projeto de Lei Complementar n⿳3 353/2006, de autoria do Deputado Sarney Filho, cria o Anexo de Metas Sociais à lei de diretrizes orçamentárias. A ele, foram apensados ainda os Projetos de Leis Complementares no 451 e 461, de 2007, de autoria do Deputado João Hermann, que incluíam o Relatório de Cumprimento das Metas Sociais, o Relatório de Gestão Social na Lei de Responsabilidade Fiscal e o Projeto de Lei Complementar no 169/2012, do Deputado Pedro Novais, que determina que o projeto de lei
} 
complementar no 353/2006 indica que o projeto está pronto para pauta na Comissão de Finanças e Tributação, na qual o relator do projeto, Deputado Júlio César, apresentou parecer no dia 30 de outubro de 2013 pela aprovação do projeto de lei complementar $n^{\circ}$ 264/2007 e pela rejeição de todos os demais projetos de lei discutidos. Segundo o parecer:

Ao reconhecer-se que o PLP $\mathrm{n}^{\circ} 264$, de 2007, se constitui na proposição mais completa e abrangente, ressalta-se que foi unanimemente aprovado pela Comissão de Legislação Participativa, depois da realização de várias audiências públicas e de múltiplas manifestações da sociedade civil. Sem demérito às demais proposições, a proposta da CLP coroa um esforço de consideráveis parcelas da sociedade civil brasileira, representadas por cerca de cinco dezenas de organizações sociais, há muito tempo engajadas no propósito de, sem prejuízo da necessária disciplina fiscal que devem observar nossas Administrações Públicas, colocar no centro das atenções dos governos os objetivos que constituem as atividades-fim do Estado, institucionalizando a mais ampla participação dos cidadãos por meio dos Conselhos em cada uma das esferas de Poder (BRASIL, 2013, p. 4).

Ou seja, de acordo com o relatório, o Projeto de Lei Complementar apresentado pelo FBO permite colocar as metas sociais no mesmo nível das preocupações com a responsabilidade fiscal. Cumpre salientar que, em 2011, os movimentos e organizações que compunham a Plataforma pela Reforma do Sistema Político e o Movimento de Combate à Corrupção Eleitoral apresentaram "proposta de iniciativa popular para a reforma do sistema político brasileiro", no qual apoiavam a proposta do FBO. ${ }^{182}$

Em paralelo às discussões sobre criação de metas fiscais, a ampliação da participação no orçamento, inclusive com a possibilidade de criação de um orçamento participativo nacional, talvez pudesse fazer com que cidadãs e cidadãos participassem

do plano plurianual seja acompanhado de um anexo de política fiscal, que indique como a política macroeconômica se compatibilizaria com o desenvolvimento social.

${ }^{182}$ A proposta está disponível em: <http://www.reformapolitica.org.br/historico/2011/213-proposta-deiniciativa-popular-para-a-reforma-do-sistema-politico-brasileiro.html> (último acesso em 12 de outubro de 2014). 
da deliberação sobre o destino dos recursos públicos de modo a incluir outros temas na agenda de discussão fiscal, para além da sustentabilidade da dívida pública. ${ }^{183}$

Esta pesquisa não pretende discutir em detalhes essas demandas sociais, uma vez que elas não constituem propriamente efeitos da implementação do regime jurídico da política fiscal. Pretende-se apenas deixar registrado que elas constituem possibilidades concretas de desenvolvimento do desenho institucional das finanças públicas no âmbito da transparência e dos mecanismos de prestação de contas.

De qualquer forma, como o próprio relatório do TCU mencionado acima antecipou, a possibilidade mais concreta de desenvolvimento do regime jurídico da política fiscal presente hoje parece ser a retomada das discussões a respeito da criação de um Conselho de Gestão Fiscal, já previsto inclusive na Lei de Responsabilidade Fiscal, exclusivamente dedicado a avaliar metas fiscais. Segundo a lei, o Conselho seria “constituído por representantes de todos os Poderes e esferas de Governo, do Ministério Público e de entidades representativas da sociedade" e teria como objetivo acompanhar e avaliar permanentemente a política e a operacionalidade da gestão fiscal. O Conselho teria significativo poder normativo para "adotar normas de consolidação das contas públicas, padronização das prestações de contas e dos relatórios e demonstrativos de gestão fiscal de que trata esta Lei Complementar".

Esse Conselho nunca foi criado. A demora na sua criação pode representar certo receio do governo federal em criar um espaço institucional no qual novas demandas fiscais poderiam ser articuladas, o que afetaria e provavelmente mudaria substantivamente a gestão da própria política fiscal (ABRUCIO e LOUREIRO, 2002, p. 23), como as propostas de lei discutidas acima demonstram. Nos termos do desenho definido pela Lei de Responsabilidade Fiscal, o Conselho também representaria uma ameaça à capacidade do governo federal de centralizar decisões fiscais, uma vez que ele prevê a inclusão de representantes de todos os Poderes, do Ministério Público e de entidades representativas da sociedade. Ou seja, o Conselho funcionaria como espécie de fórum consultivo da gestão fiscal, mas contando com a presença de integrantes que não necessariamente estariam alinhados entre si ou com o governo, o que poderia trazer controvérsias sobre a política fiscal para dentro de um órgão responsável pela política, mesmo que esse órgão seja responsável somente por sua supervisão.

${ }^{183}$ Essa parece ser a consequência da aprovação do Decreto ${ }^{\circ} 8.243$, de 23 de maio de 2014, quando prevê, no inciso $\mathrm{V}$ do art. $4^{\mathrm{o}}$ que um dos objetivos da Política Nacional de Participação Social será o desenvolvimento de "mecanismos de participação social nas etapas do ciclo de planejamento e orçamento". 
O contexto no qual a criação do Conselho é postergada pelo governo, contudo, pode mudar a partir das recentes alegações de "contabilidade criativa", que abriram esta seção e que foram reproduzidas nas críticas à política fiscal presentes no relatório do TCU. A controvérsia sobre o grau de transparência da gestão fiscal demonstra que regras nominais e numéricas sobre política fiscal podem - mesmo que no caso brasileiro isso ainda seja controverso - ser descumpridas por elites políticas que não desejem respeitá-las. ${ }^{184}$ Neste caso, dada a falta de conhecimento técnico e de rapidez do Poder Judiciário, o mecanismo clássico de controle externo da Administração Pública por descumprimento de determinações legais via jurisdição tende a ser ineficaz. Não somente pela falta de conhecimento técnico e da rapidez para o julgamento, mas também por conta da insegurança quanto às possíveis consequências normativas pelo desrespeito às metas fiscais previstas. ${ }^{185}$

A existência de uma instituição fiscal independente, formada por especialistas em política fiscal - o que, no caso brasileiro, demandaria uma alteração na Lei de Responsabilidade Fiscal - e responsável por controlá-la a partir das metas fiscais previamente estabelecidas, passa a representar uma saída atraente para os atores interessados em manter a estabilidade da política fiscal em relação a essas metas, como demonstrou a passagem do TCU acima referida.

Organismos multilaterais e a arena internacional mais uma vez parecem ser relevantes na compreensão da dinâmica que determinará o desenvolvimento institucional das finanças públicas no país. Banco Mundial, Fundo Monetário Internacional e OCDE têm aprovado diversas resoluções defendendo a criação de instituições fiscais independentes para supervisão da política fiscal e das práticas orçamentárias. A OCDE aprovou, por exemplo, o documento "Recomendação do Conselho sobre os Princípios das Instituições Fiscais Independentes", em 13 de fevereiro de 2014, no qual afirmou:

Instituições fiscais independentes são órgãos independentes, financiados publicamente, sob a autoridade legal do Executivo ou do Legislativo, responsáveis pela fiscalização apartidária e pela análise

\footnotetext{
${ }^{184}$ Essa é também uma conclusão da literatura internacional sobre o tema. Ver, por exemplo, Gyórfyy: “a elaboração de metas também significa que o objetivo mais importante para os políticos é o alcance daquela meta, a despeito dos meios usados ou dos custos. Essa situação cria fortíssimos incentivos para a contabilidade criativa". No original: "targeting also means that the overarching goal of policy-makers becomes the reaching of that target regardless of the means or the costs. This situation provides very strong incentives for creative accounting." (2007, p. 56)

${ }^{185}$ Veiga da Rocha já alertou sobre o mesmo risco no controle democrático das decisões sobre política monetária pelo Judiciário: ver Veiga da Rocha (2011, p. 112).
} 
da, e em alguns casos por sugestões sobre, política fiscal e de sua performance [...] Instituições fiscais independentes têm o potencial de aprimorar a disciplina fiscal, promover maior transparência orçamentária e accountability e aumentar a qualidade do debate público sobre política fiscal (tradução nossa). ${ }^{186}$

A OCDE defende que essas instituições fiscais independentes deveriam respeitar vinte e dois princípios, agrupados de acordo com nove ideias mais gerais: (i) a instituição deveria ser de propriedade local; (ii) apartidária e independente; (iii) seus membros deveriam ter mandato claro e determinado; (iv) a instituição deveria contar com os recursos necessários para o seu desenvolvimento; (v) a relação com o Legislativo deveria ser constante; (vi) a instituição deveria contar com acesso à informação de qualidade; (vii) as ações da instituição deveriam ser transparentes; (viii) os canais de comunicação entre a instituição e a sociedade deveriam ser fortalecidos; (ix) a instituição deve ter avaliação externa. Em síntese, as instituições fiscais deveriam ficar responsáveis por exercer um controle externo dos responsáveis pelas decisões relativas à política fiscal, em especial quanto às projeções relativas aos impactos de médio e longo prazo da política fiscal e do cumprimento de metas oficiais, além de estabelecer canais de comunicação para fortalecer e divulgar o resultado de suas conclusões amplamente.

O FMI também tem entendimento semelhante:

Conselhos fiscais podem promover maior disciplina fiscal caso sejam bem formatados. A análise aponta para certas características centrais de um conselho fiscal efetivo: uma estrita independência operacional da política, a elaboração ou avaliação pública de previsões orçamentárias, forte presença no debate público (notavelmente por meio de uma estratégia de comunicação efetiva), e um papel explícito de monitorar regras fiscais (FMI, 2013, p. 1, tradução nossa). ${ }^{187}$

\footnotetext{
${ }^{186}$ Texto disponível em: $<$ http://acts.oecd.org/Instruments/ShowInstrumentView.aspx?InstrumentID=301\&InstrumentPID=316\&L ang=en \&Book=False> (último acesso em 20 de setembro de 2014). No original: "independent fiscal institutions are publicly funded, independent bodies under the statutory authority of the executive or the legislature which provide non-partisan oversight and analysis of, and in some cases advice on, fiscal policy and performance [...] independent fiscal institutions have the potential to enhance fiscal discipline, promote greater budget transparency and accountability and raise the quality of public debate on fiscal policy"

${ }^{187}$ No original "Fiscal councils can promote stronger fiscal discipline as long as they are well-designed. The analysis points to a number of key features of effective fiscal councils: a strict operational independence from politics, the provision or public assessment of budgetary forecasts, a strong presence
} 
Ou seja, de modo semelhante à OCDE, o FMI defende a criação de conselhos fiscais independentes como um dos modos de fortalecer a "disciplina fiscal" e o respeito às metas fiscais. As características alegadamente importantes para essas instituições, de acordo com o FMI, são semelhantes àquelas previstas na resolução da OCDE: independência da política; capacidade de avaliar o orçamento e projetar desenvolvimentos futuros; estratégia de comunicação efetiva. ${ }^{188}$

Como se percebe, essa agenda de reforma institucional das finanças públicas envolve aspectos centrais de instituições políticas de qualquer Estado democrático. $\mathrm{O}$ orçamento sempre representou um espaço de disputa política por excelência. As decisões fiscais sobre quantos e quais projetos públicos deveriam ser financiados foram tradicionalmente interpretadas como sendo de competência do Legislativo e/ou do Executivo. O caso brasileiro mostra que a criação de regras fiscais para delimitar a discricionariedade dos responsáveis pelas decisões fiscais foi um primeiro momento relevante de reforma do regime jurídico da política fiscal e dessas instituições políticas. A criação de instituições fiscais independentes parece ser o segundo.

A legitimidade democrática da gestão da política fiscal parece ser disputada justamente no contexto dessas reformas institucionais: a política fiscal é legítima porque decidida politicamente e de acordo com regras democráticas tradicionais ou ela é legítima quando protegida dos próprios políticos que supostamente deveriam defini-la e definidas de acordo com critérios supostamente técnicos a respeito da sustentabilidade prevista da dívida pública? Esta pesquisa não pretende apresentar respostas a essa questão. A conclusão tentará analisar, contudo, como essas questões se desenvolvem a partir das principais hipóteses dessas pesquisas, em especial no contexto brasileiro.

in the public debate (notably through an effective communication strategy), and an explicit role in monitoring fiscal policy rules." (FMI, 2013, p. 1).

${ }^{188}$ O Banco Mundial, no recente relatório sobre a economia mundial em 2014, tem opinião semelhante. De acordo com o Banco Mundial: "Autoridades fiscais ao redor do mundo rotineiramente desviam de planos sustentáveis e sofrem de uma tendência "prócíclica": eles tendem a incorrer em déficits orçamentários e acumular dívidas em épocas boas, e então não ter os recursos adequados e a flexibilidade (margem política) para estabilizar o produto em tempos ruins. Uma solução proposta. A criação de um conselho fiscal independente pode prover os incentivos corretos para que o governo acumule os recursos para lidar com depressões cíclicas e contingências de longo-prazo." (BANCO MUNDIAL, 2014, p. 34, tradução nossa). No original: "Fiscal authorities around the world routinely deviate from sustainable plans and suffer from a "procyclical" bias: they tend to run budget deficits and accumulate debt in good times, and then lack adequate resources and flexibility ("policy space") to stabilize output in bad times. A proposed solution. The creation of an independent fiscal council can provide the right incentives for the government to build up resources to cope with cyclical downturns and long-run contingencies." 


\section{Conclusão: legitimidade democrática, direito e política fiscal}

Este estudo sobre o regime jurídico da política fiscal no Brasil buscou demonstrar a importância de se conciliar perspectivas jurídicas e econômicas em pesquisas sobre políticas macroeconômicas em uma democracia. Como se defendeu no primeiro capítulo, o campo de pesquisa sobre políticas macroeconômicas vai além de seus aspectos funcionais e econômicos. Na realidade, a perspectiva democrática do seu desenvolvimento perpassa todos os âmbitos que foram discutidos nesta dissertação. $\mathrm{Na}$ análise do caso brasileiro, a perspectiva de embates políticos democráticos permite perceber como as próprias funções de um regime jurídico para a política fiscal são objeto de disputa social e que o direito é visto como um dos meios privilegiados para legitimar socialmente determinadas funções das políticas. A análise de direito e macroeconomia realizada neste trabalho busca dar centralidade à perspectiva democrática sem ignorar os aspectos funcionais que o direito possui para a política fiscal. Com isso, a dinâmica histórica do direito também se torna central.

Esta pesquisa permitiu demonstrar como a reforma do regime jurídico da política fiscal no país, na década de 1980, não estava conectada a uma agenda do ajuste físcal, cenário que se alterou significativamente na década seguinte. A consolidação de um novo regime jurídico da política fiscal com a aprovação da Lei de Responsabilidade Fiscal, em 2000, vinculou-se ao objetivo de assegurar a sustentabilidade da dívida pública, em detrimento de outras possíveis metas que a política fiscal poderia assumir. As regras e os princípios aprovados com a reforma acabaram por alterar quatro âmbitos da política fiscal: o das relações federativas; o das relações entre Legislativo e Executivo; o da criação de limites legais; a previsão de novos mecanismos de transparência e de prestação de contas.

Ao contrário do que normalmente se defende na literatura, essa agenda de reforma do regime jurídico não era prioritariamente doméstica, mas estava imersa em uma agenda internacional sobre o desenvolvimento das finanças públicas, como se demonstrou no capítulo 3. No caso brasileiro, em particular, a arena internacional foi fundamental para facilitar a aprovação da reforma no âmbito doméstico. Contrapondose ao binômio "imposição internacional"/"ausência de importância da arena internacional", esta pesquisa identificou quatro vetores de influências internacionais na aprovação da Lei de Responsabilidade Fiscal: a crise das economias emergentes no final da década de 1990 criou o contexto geral para aprovação da reforma; experiências 
internacionais prévias serviram como o padrão de excelência para as reformas que foram promovidas; o discurso internacional sobre política fiscal permitiu que as autoridades sugerissem domesticamente que a aprovação do novo regime sinalizaria a credores e investidores a adoção de boas práticas; o acordo entre Brasil e FMI alavancou os esforços das autoridades do Poder Executivo que pressionavam pela aprovação da reforma.

O último capítulo da dissertação realizou a análise dos efeitos da reforma do regime jurídico nos quatro âmbitos alterados. Por um lado, essa análise permitiu perceber que a reforma foi parcialmente bem sucedida quando mensurada a partir dos próprios mecanismos criados, em particular no que diz respeito à concentração de poderes fiscais na União e no Executivo Federal e na criação de alguns mecanismos de transparência. Por outro, a reforma não parece ter limitado completamente a discricionariedade dos agentes que são responsáveis por definir a política fiscal, o que pode impactar negativamente os objetivos da agenda do ajuste fiscal e da sustentabilidade da dívida pública. Como se argumentou no capítulo 4, certos atores do governo federal parecem reter não só a competência legal como também a capacidade de fato de propor e perseguir discricionariamente metas para a gestão da política fiscal. Esse diagnóstico da situação atual do regime jurídico da política fiscal permite sugerir que ainda estão no horizonte diferentes possibilidades de desenvolvimento jurídico e institucional das finanças públicas.

No âmbito da relação federativa, a principal controvérsia parece residir no balanceamento de poderes fiscais entre União e estados. Embora a União tenha centralizado consideravelmente a capacidade de definir o endividamento público, um dos principais mecanismos para que isso ocorresse foi a celebração dos contratos de refinanciamento das dívidas estaduais, a partir do marco normativo da Lei 9.496/1997, a lei de reestruturação das dívidas estaduais. A maior parte dos contratos celebrados entre União e estados tem prazo de vigência de 30 anos. E é possível imaginar que, tão logo esses contratos se aproximem do seu termo, a discussão sobre o modelo de controle das finanças públicas estaduais a ser adotado seja retomada.

No âmbito da separação de poderes, a relação entre Executivo e Legislativo não é estável. Como se espera que tenha ficado claro no último capítulo desta dissertação, a concentração de poderes fiscais no Executivo tem sido mecanismo central para que as metas fiscais estabelecidas sejam alcançadas, ou por meio do contingenciamento de recursos ou por meio do mecanismo da desvinculação das receitas da União. As 
recentes propostas a respeito do orçamento impositivo e da não renovação das emendas constitucionais sobre desvinculação das receitas da União, que têm ganhado força tanto doutrinariamente como institucionalmente, apontam para uma possibilidade real de substantiva modificação da lógica institucional orçamentária vigente no país.

No âmbito de regras que delimitam a discricionariedade dos gestores fiscais, diversas possibilidades de desenvolvimento institucional permanecem abertas. Os dois melhores exemplos foram dados no capítulo 4, quando se demonstrou que as metas iniciais previstas no acordo com o FMI se relacionavam às necessidades de financiamento do setor público e à discussão que ganhou força no governo federal em 2005, a respeito de uma regra explícita de déficit nominal zero para a política fiscal. Ambas as regras restringiriam mais significativamente a liberdade de gestão da política fiscal no país, ainda que essas possibilidades não pareçam estar na agenda política atual.

Ainda assim, as discussões sobre transparência da gestão fiscal demonstram que a mera previsão de regras numéricas ou fixas de política fiscal pode ser sabotada por meio de mecanismos criativos de contabilidade ou de mudanças sutis nas metodologias de cálculo. É até possível argumentar que a criação dessas regras estimula esse tipo de ação por parte do governo, independentemente da ideologia dos atores responsáveis pelas políticas. Nesse sentido, no âmbito dos mecanismos de prestação de contas e de transparência, identificaram-se duas possibilidades de desenvolvimento institucional da política fiscal: propostas de maior participação ou da ampliação de metas para a política fiscal para outras áreas, como metas sociais; e a previsão de deslocamento de parte das prerrogativas relacionadas à política fiscal para uma instituição fiscal independente, como, por exemplo, a instituição de um Conselho de Gestão Fiscal. Não parece ser impossível que os dois cenários convivam, de modo que a maior participação ou a ampliação de metas para a política físcal se dê com a transferência progressiva de prerrogativas fiscais para uma instituição fiscal independente.

Esta pesquisa tentou demonstrar que uma reflexão preocupada com a dimensão da legitimidade democrática das transformações do regime jurídico da política fiscal permite identificar interesses, disputas e atores que estão por trás das propostas das mudanças jurídicas apresentadas. Como se percebe, a dimensão funcional do direito da política fiscal não foi deixada de lado na análise, mas recolocada a partir de uma nova perspectiva: tentou-se demonstrar que os próprios objetivos da política fiscal estão em disputa democrática e que as instituições - regras e princípios jurídicos e/ou constitucionais - são inerentemente instáveis para determiná-las definitivamente. 
Desse modo, a possível vantagem de uma pesquisa de direito e macroeconomia que coloca a questão da legitimidade democrática como objeto central de reflexão é a de que ela não precisa estar conectada a nenhuma das agendas específicas sobre política fiscal. Uma pesquisa de direito e macroeconomia consciente dos seus limites entende que o papel das principais escolhas normativas quanto ao melhor caminho a ser seguido deve ser feito e refeito de modo democrático pela sociedade, a partir do amplo debate público que demonstre as diferentes alternativas, seus possíveis defeitos e vantagens. Outro estudo talvez permita explorar como a cultura política da sociedade brasileira se conecta ao regime jurídico da política fiscal vigente e como ela afetou e pode afetar o seu desenvolvimento. Ou tentar compreender se as concepções de democracia geralmente compartilhadas estão em conformidade com o regime jurídico da política fiscal. Ou, ainda, explorar como ocorreu o desenvolvimento do regime jurídico da política fiscal em outros países, não somente no Brasil. Apesar disso, não é possível imaginar que qualquer pesquisa possa definir, isoladamente, o rumo de políticas que podem e devem ser objeto de deliberações democráticas. Esse é o caso da política fiscal. 


\section{Bibliografia}

ABRUCIO, Fernando e ASAZU, Claudia, 2003. "A gênese da Lei de Responsabilidade Fiscal (LFR): a construção de uma agenda." In Anais do ENANPAD, 2003, ENANPAD, 2003, Atibaia.

ABRUCIO, Fernando e LOUREIRO, Maria Rita, 2002. "Incrementalismo, negociação e accountability: análise preliminar das reformas fiscais no Brasil". In LOUREIRO and ABRUCIO, O estado em uma era de reformas: os anos FHC (Parte II). Brasília: MP, Seges, p. 57-102.

AFONSO, José et al., 2000. "Principios y reglas para lasfinanzas publicas: lapropuesta de laley de laresponsabilidad fiscal del Brasil", CEPAL - SERIE Seminarios $y$ conferencias, $\mathrm{n}^{\mathrm{o}}$ 3. Santiago: Economic Commission for Latin America and the Caribbean. Disponível

em: <http://www.eclac.org/publicaciones/xml/4/7284/lcl1456e_IIIb.pdf>

ALESINA, Alberto e ARDAGNA, Silvia 2010. "Larges changes in fiscal policy: taxes versus spending”. In Tax Policy and the Economy, Volume 24 (2010). Chicago: The University of Chicago Press.

ALESINA, Alberto e PEROTTI, Roberto, 1995. "Fiscal expansions and fiscal adjustments in OECD Countries" in NBER Working Paper n ${ }^{\circ}$ 5214. Agosto, 1995.

ALESINA, Alberto e PEROTTI, Roberto, 1996. "Fiscal Adjustments in OECD Countries: Composition and Macroeconomic effects" in NBER Working Paper $n^{\circ} 5370$. Agosto, 1996.

ALESINA, Alberto e ROUBINI, Nouriel, 1997. Political cycles and the macroeconomy. Cambridge: The MIT Press.

ALESINA, Alberto, HAUSMANN, Ricardo, HOMMES, Rudolf e STEIN, Ernesto, 1999. "Budget institutions and fiscal performance in Latin America". InterAmerican Development Bank. Office of the Chief Economist. Working Paper Series 394.

ALVES, Romulo e MONTES, Gabriel, 2012. "O debate acerca dos objetivos e condução da política fiscal: uma abordagem crítica à visão convencional." In Economia e Sociedade, Campinas, v. 21, n.2 (45), pp. 363-385, agosto 2012.

ALVES, Tiago e SANTOS, Sandra, 2011. "O impacto da Lei de Responsabilidade Fiscal no desempenho financeiro e na execução orçamentária dos 
municípios no Rio Grande do Sul de 1997 a 2004." In Revista de Administração Pública, v. 45, n.1, pp. 181-208.

ARAUJO, Fernando e LOUREIRO, Maria Rita, 2005. "Por uma metodologia pluridimensional de avaliação da LRF”. In Revista da Administração Pública - RAP, vol. 39, num. 6, nov-dec. 2005, pp. 1231-1251.

ARAÚJO, Jorge, CHIEZA, Rosa, e JÚNIOR, Geraldo, 2009. "Impactos da lei de responsabilidade fiscal sobre os componentes da despesa dos municípios gaúchos: análise econométrica." In Ensaios FEE, v. 30, Special Edition, oct. 2009, p. 363-390, Porto Alegre.

ARROW, Kenneth, [1951] 1963. Social choice and individual values. New Haven: Yale University Press.

ASAZU, Claudia, 2003. Os caminhos da lei de responsabilidade fiscal (LRF): instituições, idéias e incrementalismo. Tese de Mestrado. São Paulo: Fundação Getúlio Vargas.

BACHA, Edmar e GOLDFAJN, Ilan, 2008. Como reagir à crise? Políticas econômicas para o Brasil. Rio de Janeiro: IEPE/Casa das Garças. Disponível em: <http://iepecdg.com.br/Arquivos/livro/LIVRO_CdGv1.7.pdf>

BACHA, Edmar e DE BOLLE, Monica, 2011. Novos Dilemas da Política Econômica - Ensaios em homenagem a Dionísio Dias Carneiro. Rio de Janeiro: LTC Editora.

BANCO CENTRAL, 2014. Política fiscal: nota para a imprensa de 30 de setembro de 2014. Brasília: Banco Central do Brasil.

BANCO MUNDIAL, 1999. World Development Report 1999/2000: entering the $21^{\text {st }}$ century - the changing development landscape. Oxford University Press: New York.

Disponível

em: <https://openknowledge.worldbank.org/bitstream/handle/10986/5982/WDR\%201999_2 000\%20-\%20English.pdf?sequence=1>

BANCO MUNDIAL, 2001. Implementation completion report on a loan in the amount of US\$ 506.06 million to the Federative Republic of Brazil for a fiscal and administrative reform special sector adjustment program. Disponível em: <http://wwwwds.worldbank.org/external/default/WDSContentServer/WDSP/IB/2002/02/09/000094 946_02012504075647/Rendered/PDF/multi0page.pdf>

BANCO MUNDIAL, 2014. World Development Report 2014: risk and opportunity. Managing risk for development. Washington: The World Bank. 
BARBOSA, Nelson e SOUZA, José, 2010. Inflexão do governo Lula: política econômica, crescimento e distribuição de renda. Disponível em: $<$ http://nodocuments.files.wordpress.com/2010/03/barbosa-nelson-souza-jose-antoniopereira-de-a-inflexao-do-governo-lula-politica-economica-crescimento-e-distribuicaode-renda.pdf>

BARBOSA, Samuel, 2013. "Constituição, democracia e indeterminação social do direito" in Revista Novos Estudos, n 96, Julho de 2013.

BARRO, Robert, 1979. "On the determination of the public debt". In The Journal of Political Economy, Chicago: University of Chicago Press, vol. 87 (5), nº 5, parte 1, Outubro de 1979, pp. 940-971.

BAYAR, Ali H. e SMEETS, Bram, 2009. "Economic, political and institutional determinants of budget deficits in the European Union" in CESIFO Working Paper $n^{o}$ 2611 .

BEGHIN, Nathalie e ZIGONI, Carmela, 2014. Avaliando os websites de transparência orçamentária nacionais e sub-nacionais e medindo impactos de dados abertos sobre direitos humanos no Brasil. Brasília: Instituto de Estudos Socioeconômicos (INESC).

BENASSI-QUÉRÉ, Agnès et al., 2010. Economic policy: theory and practice. New York: Oxford University Press.

BERCOVICI, Gilberto e MASSONETTO, Luis, 2007. "A constituição dirigente invertida: a blindagem da constituição financeira e a agonia da constituição econômica." In Revista Trimestral de DireitoPúblico, v. 45, p. 78-89, 2007.

BERNSTEIN, Steven e CASHORE, Benjamin, 2012. "Complex global governance and domestic policies: four pathways of influence". International Affairs 88, pp. 585-604.

BIASOTO Jr., Geraldo, 1995. A questão fiscal no contexto da crise do pacto desenvolvimentista, Campinas: Tese de Doutorado apresentada ao Instituto de Economia da UNICAMP.

BLANCHARD, Olivier, 2012. Macroeconomics. 6th Edition. New York: Pearson.

BLYTH, Mark, 2013. Austerity: the history of a dangerous idea. Oxford: Oxford University Press, 2013.

BORGES NETO, João Machado, 2003. "Um governo contraditório" in Revista da Sociedade Brasileira de Economia Política $n^{o}$ 12. São Paulo. Disponível em: <http://www.sep.org.br/revista> 
BRAGA, José, 1982. "Os orçamentos estatais e a política econômica" in BELlUZZO, Luiz e COUTINHO, Renata (orgs.), Desenvolvimento Capitalista no Brasil: Ensaios sobre a crise. São Paulo: Editora Brasiliense.

BRASIL, 1984. Relatório da Comissão Especial para discutir a reforma bancária criada pelo voto CMN n ${ }^{o}$ 283/1984. Publicado na Gazeta Mercantil de 30 de novembro de 1984.

BRASIL, 1993. Programa de ação imediata. Ministério da Fazenda: Gabinete do Ministro, Assessoria de Comunicação Social. Mimeografado.

BRASIL, 1998. Programa de estabilidade fiscal. Disponível em: <http://www.fazenda.gov.br/portugues/ajuste/pef98.asp>

BRASIL, 2001. Projeto de Lei do Senado $n^{o}$ 205, de 2001. Senado Federal: projeto de lei do senado de autoria da Senadora Marina Silva.

BRASIL, 2003. Política Econômica e Reformas Estruturais. Disponível em: <http://www.fazenda.gov.br/portugues/releases/2003/Politica\%20Economica.pdf>

BRASIL, 2004. Reformas microeconômicas e crescimento de longo prazo. Disponível em: <http://www.fazenda.gov.br/spe/publicacoes/reformasinstitucionais/estudos/Texto_Vers aoFinal5.pdf>

BRASIL, 2006. Sugestão $n^{o}$ 210/2006. Câmara dos Deputados: Comissão de Legislação Participativa. Sugestão de projeto de lei complementar do Fórum Brasil de Orçamento.

BRASIL, 2012. Estatísticas fiscais de estados, Brasília: Secretaria do Tesouro Nacional. Disponível

em: <http://www3.tesouro.gov.br/estados_municipios/download/Graficos_Acima_Linha.pdf $>$

BRASIL, 2013. Relatório sobre o projeto de lei complementar $n^{o} 353$, de 2006. Câmara dos Deputados: Deputado Julio Cesar. Brasília.

BRASIL, 2014a. Indicadores Fiscais com informações até março de 2014. Elaborado pelo Banco Central. Disponível em: <http://www4.bcb.gov.br/pec/gci/port/focus/faq\%204-indicadores\%20fiscais.pdf>

BRASIL, 2014b. Série histórica INPC/IBGE. Disponível em: $<$ http://www.ibge.gov.br/home/estatistica/indicadores/precos/inpc_ipca/defaultseriesHis t.shtm> 
BRENDER, Adi e DRAZEN, Allan, 2004. "Political Budget Cycles in New versus Established Democracies" in NBER Working Paper n ${ }^{\circ}$ 10539. Junho, 2004.

BRESSER-PEREIRA, Luiz Carlos, 2013. "O governo Dilma frente ao "tripé macroeconômico' e à direita liberal e dependente" in Revista Novos Estudos CEBRAP $\mathrm{n}^{\circ}$ 95, março de 2013.

BRIOTTI, Maria, 2005. "Economic reactions to public finance consolidation: a survey of the literature". In Occasional Paper Series $n^{\circ} 38$, European Central Bank, Germany, 2005.

BUCHANAN, James e WAGNER, Richard, [1977], 2000. Collected Works of James M. Buchanan, vol. 8: Democracy in Deficit: The political legacy of Lord Keynes. Edição de 1977: New York: Academic Press. Edição de 2000: Indianapolis: Liberty Fund.

CAMPOS, Ed e PRADHAN, Sanjay, 1996. "Budgetary institutions and expenditures outcomes: binding governments to fiscal performance". Policy Research Working Paper 1646, The World Bank. Disponível em: <http://elibrary.worldbank.org/content/workingpaper/10.1596/1813-9450-1646>

CASHORE, Benjamin e HOWLETT, Michael, 2009. "The dependent variable problem in the study of policy change" in Journal of Comparative Policy Analysis, vol. $11, \mathrm{n}^{\mathrm{o}} 1$, p. $29-42$.

CORBARI, Ely e MACEDO, Joel, 2009. "Efeitos da Lei de Responsabilidade Fiscal no endividamento dos Municípios Brasileiros: uma análise de dados em painéis", in Accounting and Finance Review, v. 20, n.51. São Paulo.

CORREA, Diego, 2007. Instiuições Orçamentárias e desempenho fiscal: um estudo de caso do Brasil, Chile e Argentina nos anos 1990 e 2000. Dissertação de Mestrado da Faculdade de Filosofia, Letras e Ciências Humanas da Universidade de São Paulo. Área de Conhecimento: Ciência Política. São Paulo: Universidade de São Paulo.

CYSNE, Rubens, 1994. "Imposto inflacionário e transferências inflacionárias no Brasil” in Revista de Economia Política, vol. 14, nº 3 (55), julho-setembro/1994.

DABLA-NORRIS, Era et al., 2010. Budget Institutions and Fiscal Performance in Low-Income countries. IMF: Working Paper. Disponível em: <http://www.imf.org/external/pubs/ft/wp/2010/wp1080.pdf>

DALLAVERDE, Aleksandra, 2009. A titularidade exercida pelo poder executivo sobre a gestão das finanças públicas e o desequilíbrio causado no quadro da separação 
de poderes. Dissertação de mestrado em direito: Faculdade de Direito da Universidade de São Paulo.

DA SILVA, Gerson Luiz Cardoso, PALMEIRA, Eduardo Mauch, QUINTANA, Alexandre Costa, 2007. "Sistema integrado de Administração Financeira do Governo Federal - SIAFI - Necessidade, criação e evolução" in Observatório de La Economia $\begin{array}{llll}\text { Latinoamericana } & n^{\circ} & 86 . & \text { Disponível }\end{array}$ <http://www.eumed.net/cursecon/ecolat/br/07/glcs.htm>

DCD, 1999 e 2000. Diário da Câmara dos Deputados, abril de 1999 a fevereiro de 2000 .

DCN, 1989. Diário do Congresso, 22 de março de 1989, seção I, p. 1356.

DE HAAN, Jakob e VOLVERINK, B., 2000. Fragmented government effects on fiscal policy: new evidence. Disponível em: <http://ccso.eldoc.ub.rug.nl/FILES/root/2000/200006/200006.pdf>

DE HAAN, Jakob e MINK, Mark, 2005. "Has the stability and growth pact impeded political budget cycles in the European Union"? in CESifo Working Paper Series $n^{\circ}$ 1532. Munich: Cesifo.

DE HAAN, Jakob e STURM, Jan-Egbert, 1994. "Political and institutional determinants of fiscal policy in the European Community" in Public Choice, v. 80, July, 1994, pp. 157-172.

DE PAULA, Luiz Fernando e MODENESI, André, 2013. "Consequências do Sr. Mantega" in Valor Econômico, de 12 de julho de 2013.

DIAS, Fernando Álvares, 2011. Desvinculação das receitas da União: ainda necessária?. Brasília: Senado Federal.

DSF, 2000. Diário do Senado Federal, fevereiro a maio de 2000.

DURAN, Camila Villard, 2012. "The economic crisis and the role of law in monetary policy: a study of the political and social accountability of the Brazilian Central Bank (Bacen), the European Central Bank (ECB) and the Federal Reserve (Fed)". Journal of International Banking Law and Regulation, v. 27, p. 306-317, 2012

FABRIZIO, Stefania e MODY, Ashoka, 2006. "Can budget institutions counteract political indiscipline?" in IMF Working Paper WP/06/123.

FANTI, Fabíola, 2009. Políticas de saúde em juízo: um estudo sobre o município de São Paulo. Dissertação de Mestrado em Ciência Política: Faculdade de Filosofia, Letras e Ciências Humanas da Universidade de São Paulo. 
FARIA, José Eduardo, 2011. O Estado e o Direito depois da crise. São Paulo, Saraiva.

FARIA, Rodrigo de Oliveira, 2009. Natureza jurídica e flexibilidade orçamentária. Tese de Mestrado em Direito: Faculdade de Direito da Universidade de São Paulo.

FERRAZ, Octavio, 2011. Harming the poor through social rights litigation: lessons from Brazil. Disponível em: 〈http://www.corteidh.or.cr/tablas/r27170.pdf>

FIGUEIREDO, Argelina e LIMONGI, Fernando, 2008. Política orçamentária no presidencialismo de coalizão. Rio de Janeiro: FGV Editora.

FILC, Gabriel e SCARTASCINI, Carlos, 2004. Budget institutions and fiscal outcomes. Ten years of inquiry on fiscal matters at the research department. Washington: Inter-American Development Bank.

FILC, Gabriel e SCARTASCINI, Carlos, 2007. "Budgetary institutions" in LORA, Eduardo (ed.) The State of State Reform in Latin America, Palo Alto: Stanford University Press.

FIORAVANTE, Dea, PINHEIRO, Maurício, e VIEIRA, Roberta, 2006. Lei de responsabilidade fiscal e finanças públicas municipais. Texto para discussão $\mathrm{n}^{\circ} 1223$. Brasília: IPEA. Disponível em: <http://www.ipea.gov.br/portal/index.php?option=com_content $\& v i e w=a r t i c l e \& i d=480>$

FMI e BRASIL: todos os documentos estão disponíveis em http://www.imf.org/external/country/BRA/

FMI, 2013. The functions and impact of fiscal councils. Disponível em: <http://www.imf.org/external/np/pp/eng/2013/071613.pdf>

FRANCO, Gustavo, [1996] 1998. A inserção externa e o desenvolvimento. Publicado pela Revista de Economia Política, vol. 18, $\mathrm{n}^{\circ} 3$ (71), julho-setembro de 1998.

Disponível

em: <http://geein.fclar.unesp.br/bibliografia/a_insercao_externa_e_o_desenvolvimento.pdf >

FRANZESE, Robert, 2002. "Electoral and partisan cycles in economic policies and outcomes" in Annual Review of Political Science, vol. 5, Junho. 2002, pp. 369-421.

FSP, 1999a. "Malan descarta plano de criar mais tributos" in Folha de São Paulo, 22 de junho de 1999. Disponível em: <http://www1.folha.uol.com.br/fsp/dinheiro/fi22069903.htm>

FSP, 1999b. "Medo da responsabilidade" in Folha de São Paulo, 8 de agosto de 1999. Disponível em: <http://www1.folha.uol.com.br/fsp/opiniao/inde080899.htm> 
GADELHA, Sérgio Ricardo, 2011. “Análise dos impactos da Lei de Responsabilidade Fiscal sobre a despesa de pessoal e a receita tributária nos municípios brasileiros: um estudo com modelo probit aplicado a dados em painel" in Revista Brasileira de Economia de Empresas, v. 11, nº 1, 2011.

GERARDO, José Carlos e NASCIMENTO, Edson R., 2012. Dois anos da Lei de Responsabilidade Fiscal. Disponível em: <http://www3.tesouro.fazenda.gov.br/hp/downloads/lrf2ed.pdf>

GIACOMONI, James, 2012. Orçamento público. 16 ${ }^{\mathrm{a}}$ edição. São Paulo: Editora Atlas.

GIAMBIAGI, Fábio, 2004. “A política fiscal do governo Lula em perspectiva histórica: qual é o limite para o aumento do gasto público?". In Planejamento e Políticas Públicas nº 27, jun/dez 2004, Brasília: IPEA.

GIAMBIAGI, Fábio 2008. “18 anos de política fiscal no Brasil: 1991/2008”. In Revista de Economia Aplicada, São Paulo, v.12, n.4, pp. 535-580, out-dez 2008.

GIAMBIAGI, Fábio e ALÉM, Ana Cláudia, 2011. Finanças públicas: teoria e prática no Brasil. Rio de Janeiro: Elsevier Campus.

GIAVAZZI, Francesco e MISSALE, Alessandro, 2004. "Public debt management in Brazil". NBER Working Paper Series. Working paper 10394. Cambridge: National Bureau of Economic Research, March 2004.

GIUBERTI, Ana Carolina, 2005. Efeitos da lei de responsabilidade fiscal sobre os gastos dos municípios brasileiros. Dissertação de Mestrado apresentada à Faculdade de Economia e Administração da São Paulo.

GIUBERTI, Ana Carolina, 2012. Instituições orçamentárias e política fiscal no Brasil: Governo Federal - 1965 a 2010. Tese de doutorado apresentada à Faculdade de Economia e Administração da São Paulo.

GLEICH, Holger, 2003. "Budget institutions and fiscal performance in central and eastern European countries" in Working Paper $n^{\circ} 215$, European Central Bank.

GOULD, Erica, 2003. "Money talks: supplementary financiers and International Monetary Fund Conditionality”. In International Organization 57, n 3, pp. 551-586.

GOUVEA, Gilda Portugal, 1994. Burocracia e elites burocráticas no Brasil. Universidade de Campinas: Tese de doutorado.

GUARDIA, Eduardo e GOLDFAJN, Ilan, 2003. "Regras fiscais e sustentabilidade da dívida no Brasil”. Notas técnicas do Banco Central do Brasil n 39, julho de 2003. Brasília: Banco Central do Brasil. 
GUARDIA, Eduardo, 1992. Orçamento público e política fiscal: aspectos institucionais e a experiência recente - 1985/1991. Dissertação de Mestrado: Universidade de Campinas.

GÜNTHER, Klaus, [2004], 2006. “Crítica da Pena I” in Revista Direito GV no 4, v. 2., n.2, p. 187-204.

GÜNTHER, Klaus, [2004], 2007. “Crítica da Pena II” in Revista Direito GV $n^{o} 5$, v.1, n. 3, p. 137-150.

GYÓRFFY, Dora, 2007. Democracy and deficits: the new political economy of fiscal management reforms in the European Union. Budapest: AkadémiaiKiadó.

HALL, Peter, 1993. "Policy Paradigms, Social Learning, and the State: the case of Economic Policymaking in Britain" in Comparative Politics, vol. 25, n 3, April 1993 , 275-296.

HALLERBERG, Mark, STRAUCH, Rolf Rainer e, VON HAGEN, Juergen, 2009. Fiscal Governance in Europe, Cambridge: Cambridge University Press

INESC, 2011. Transparência orçamentária nas capitais do Brasil. Brasília. Disponível em: <http://www.inesc.org.br/biblioteca/textos/livros/transparenciaorcamentaria-nas-capitais-do-brasil>

KNIGHT, Harold, 1959. “A monetary budget” in Staff papers, Fundo Monetário Internacional.

KOPITS, George, 2004. Rules Based Fiscal Policy in Emerging Countries. New York: Palgrave.

KRUGMAN, Paul e WELLS, Robin, 2012. Macroeconomics. 3rd Edition. New York: Worth Publishers.

KRUGMAN, Paul, 2013. "How the case for austerity has crumbled", in The New York Review of Books. New York. June 6, 2013.

KUGELMAS, Eduardo e SOLA, Lourdes, 1999. "Recentralização/descentralização: dinamica do regime federativo no Brasil dos anos 1990.” In Tempo Social, Revista de Sociologia da USP, 11(2), p. 63-81, outubro.

LEITE, Cristiane, 2005. O Processo de ordenamento fiscal no Brasil na década de 1990 e a Lei de Responsabilidade Fiscal. Tese de doutorado: Departamento de Ciência Política. São Paulo: USP.

LINHARES, Fabrício, PENNA, Cristiano e BORGES, Glenda, 2013. “Os efeitos da Lei de Responsabilidade Fiscal no endividamento dos municípios do Piauí", in Revista da Administração Pública, v. 47, n. 6, Rio de Janeiro, Nov. /Dec. 2013. 
LOCHAGIN, Gabriel, 2013. A flexibilidade na gestão orçamentária. Dissertação de Mestrado: Universidade de São Paulo.

LOPREATO, Francisco Luiz, 2002. O colapso das finanças estaduais e a crise da federação. São Paulo: Editora Unesp, IE - Unicamp.

LOPREATO, Francisco Luiz, 2004. "Novos tempos: política fiscal e condicionalidades pós-80”. Revista de Economia contemporânea. Rio de Janeiro, 8(1), pp. 125-154, jan/jun 2004.

LOPREATO, Francisco Luiz, 2006. "O papel da política fiscal: um exame da visão convencional". Texto para discussão, no 119. Campinas: IE/Unicamp.

LOPREATO, Francisco Luiz, 2007. “A política fiscal brasileira: limites e entraves ao crescimento." Texto para discussão, $\mathrm{n}^{\circ} 131$. Campinas: IE/Unicamp.

LOPREATO, Francisco Luiz, 2013. Caminhos da política fiscal no Brasil. São Paulo: Editora UNESP.

LOUREIRO, Maria Rita, 2001. "Instituições, política e ajuste fisscal - O Brasil em perspectiva comparada". Revista Brasileira de Ciencias Sociais. VOl. 16, $\mathrm{n}^{\mathrm{o}}$ 17, outubro. Pp. 75-96.

LOUREIRO, Maria Rita, TEIXEIRA, Marco Antônio Carvalho, PRADO, Otávio, 2008. "Construção de instituições democráticas no Brasil contemporâneo: transparência das contas públicas" in Revista Organizações \& Sociedade, v. 15, n. 47, p. 107-119, Outubro/Dezembro 2008.

LOUREIRO, Maria Rita, SANTOS, Fabio e GOMIDE, Alexandre, 2013. "Democracia, arenas decisórias e política econômica no Governo Lula". In Revista Brasileira de Ciências Sociais. Vol. 26, nº 76, pp. 63-76. São Paulo, 2013.

MACEDO, Leandro, 2007. O Fundo Monetário Internacional e seus acordos stand-by. Belo Horizonte: Editora Del Rey.

MACHADO, Marta, 2007. Do delito à imputação: a teoria da imputação de Günther Jakobs na dogmática penal contemporânea. Tese de doutorado: Universidade de São Paulo.

MANKIW, N. Gregory, 2010. Macroeconomics. $7^{\text {th }}$ Edition. New York, Worth Publishers.

MAXFIELD, Sylvia, 1997. Gatekeepers of growth. New Jersey: Princeton University Press.

MAZZUOLI, Valerio e SILVA, Roberto, 2003. O Brasil e os acordos econômicos internacionais. São Paulo: Editora Revista dos Tribunais. 
MAZZUOLI, Valerio, 2005. Natureza jurídica e eficácia dos acordos stand-by com o FMI. São Paulo: Editora Revista dos Tribunais.

MENDONÇA, Eduardo Bastos F., 2010. A constitutionalização das finanças públicas no Brasil. Rio de Janeiro: Renovar.

MENEGUIN, Fernando B. e BUGARIN, Maurício S, 2001. "Reeleição e política fiscal: um estudo dos efeitos nos gastos públicos." Economia Aplicada, V. 5, n. 3, p. 600-22, jul./set. 2001.

MENEZES, Rafael, 2006. Efeitos da Lei de Responsabilidade Fiscal sobre as categorias e as funções de despesas dos municípios brasileiros (1998-2004). Dissertação de Mestrado: Universidade de São Paulo.

MONTEIRO, Jorge Vianna, 1998. Economia política da crise: o Programa de Estabilidade Fiscal. Disponível em: <http://bibliotecadigital.fgv.br/ojs/index.php/rap/article/view/7772/6371>

MORA, Monica, 2002. Federalismo e Dívida Estadual no Brasil. Texto para discussão no 866. Rio de Janeiro, IPEA, Março de 2002.

MULAS-GRANADOS, Carlos, 2003. "The political and economic determinants of budgetary consolidation in Europe" in European Political Economy Review, vol. 1, n. 1, Spring, 2003, pp. 15-39.

MULAS-GRANADOS, Carlos, ONRUBIA, Jorge e JIMENEZ, Javier Salinas, 2009. "Do budget institutions matter?: Fiscal Consolidation in the New EU Member States", in Eastern European Economic, M.E. Sharpe, vol. 47(1), pp. 60-91.

NAKAGUMA, Marcos Y. e BENDER, Siegfried, 2006. “A Emenda da Reeleição e a Lei de Responsabilidade Fiscal: Impactos sobre Ciclos Políticos e Performance Fiscal dos Estados (1986-2002).” inEconomia Aplicada (Impresso), v. 10, p. 377-397.

NEUMANN, Franz. The Democratic and The Authoritarian State: essays in political and legal theory. Ed. Herbert Marcuse. Illinois: Free Press, 1957.

NEUMANN, Franz, The Rule of Law. Political theory and the legal system in modern society. Leamington: Berg, 1986.

NOBRE, Marcos, 2003. "Apontamentos sobre a pesquisa em direito no Brasil”, in Novos Estudos, n 66, Julho/2003, pp. 145-154.

NOBRE, Marcos, 2013. Imobilismo em movimento: da redemocratização ao governo Dilma. São Paulo: Companhia das Letras.

NÓBREGA, Maílson da, 2005. O futuro chegou: instituições e desenvolvimento no Brasil. São Paulo: Globo. 
NOVELLI, José Marcos, 2001. Instituições, política e ideias econômicas: o caso do Banco Central do Brasil (1965-1998), São Paulo: Annablume.

NUNES, Selene P.; NUNES Ricardo C, 2003. Dois anos de responsabilidade fiscal no Brasil: uma avaliação dos resultados à luz do modelo do fundo comum. Brasília: Universidade de Brasília. Working paper n. 5.

OCDE, 1997. Modern budgeting. Disponível em: <http://www.oecd.org/france/36233618.pdf>

OLIVEIRA, Regis, 2013. Curso de direito financeiro. 5a Edição. São Paulo: Editora Revista dos Tribunais.

OREIRO, José Luiz, SICSÚ, João e DE PAULA, Luis F., 2004. "Controle da dívida pública e política fiscal: uma alternativa para um crescimento auto-sustentado da Economia Brasileira". In: Agenda Brasil: políticas econômicas para o crescimento com estabilidade de preços. São Paulo: Manole, v. 1, p. 117-152

OREIRO, José Luiz, 2014. "Muito Além do Tripé”. Texto apresentado no seminário Indústria e Desenvolvimento Produtivo do Brasil. São Paulo: Escola de Economia de São Paulo da Fundação Getúlio Vargas. Disponível em: <http://jlcoreiro.files.wordpress.com/2014/05/seminc3a1rio-industria-2014.pdf>

PAULANI, Leda, 2008. Brasil delivery. São Paulo: Editora Boitempo.

PER MOLANDER, 2001. "Budgeting procedures and democratic ideals: an evaluation of Swedish reforms" in Journal of Public Policy, $\mathrm{n}^{\circ}$ 21. Cambridge: Cambridge University Press, pp. 23-52.

PEROTTI, Roberto e KONTOPOULOS, Yiano, 2002. "Fragmented fiscal policy" in Journal of Public Economics, nº 86, Elsevier Science, pp. 191-222.

PERRY, Guillermo, 2002. "Can fiscal rules help reduce macroeconomic volatility in the Latin America and Caribbean Region?" In Policy Research Working Paper 3080, jun. 2002.

PERSSON, Torsten e TABELLINI, Guido, 2002. "Do electoral cycles differ across political systems?". Paper apresentado em Seminário na London School of Economics. Disponível em: 〈http://cep.lse.ac.uk/seminarpapers/12-11-02-PE2.pdf>

PRAKASH, Tej e CABEZON, Ezequiel, 2008. "Public financial management and fiscal outcomes in sub-Saharan African Heavily-Indebted Poor Countries" in Working Papers IMF $\mathrm{n}^{\circ} 8 / 217$.

REINHART, Carmen and ROGOFF, Kenneth, 2010. "Growth in a time of debt" In American Economic Review, v. 100 (2), pp. 573-78, May. 
REZENDE, F. e CUNHA, A. (coordenadores). 2003. O orçamento público e a transição do poder. Rio de Janeiro: Fundação Getúlio Vargas.

ROCHA, Bruno P. e ROCHA, Fabiana F., 2008. "Consolidação fiscal nos Estados brasileiros: uma análise de duração." In Nova Economia, v. 18, p. 193-223.

ROCHA, Fabiana F. e GIUBERTI, Ana Carolina, 2008. "Assimetria cíclica na política fiscal dos Estados brasileiros." inPesquisa e Planejamento Econômico (Rio de Janeiro), v. 38, p. 253-275, 2008.

RODRIGUEZ, José Rodrigo, 2013. “A desintegração do status quo: direito e lutas sociais" in Revista Novos Estudos, n 96, Julho de 2013.

ROUBINI, Nouriel e SACHS, Jeffrey, 1989a. "Government spending and budget deficits in the industrial countries", in Economic Policy, vol. 4, n. 8, pp. 100-132, New York: Blackwell Publishing.

ROUBINI, N. e SACHS, J., 1989b. "Political and economic determinants of budget deficits in the industrial democracies" in European Economic Review no 33. North-Holland: Elsevier Science Publishers, pp. 903-938.

SAAD-FILHO, Alfredo e MORAIS, Lécio, 2011. "Da economia política à política econômica: o novo-desenvolvimentismo e o governo Lula" in Revista de Economia Política, vol. 31, nº4 (124), pp. 507-527, out/dez 2011.

SAKURAI, Sergio. "Déficit e ajuste fiscal nos Municípios Paulistas: uma análise para o período 1989 - 2001 via dados em painel" in Revista Economia, jul. 2005, v. 6, n. 2, p. 463-488.

SALAMA, Bruno Meyerhof, 2013. "The Art of Law \& Macroeconomics". University of Pittsburgh Law Review, v. 74, p. 1, 2013

SANTOLIN, Roberto, JAYME JR., Frederico, e REIS, Julio César, 2009. "Lei de responsabilidade fiscal e implicações na despesa de pessoal e de investimento nos municípios mineiros: um estudo com dados em painel dinâmico". Textos para discussão CEDEPLAR - UFMG. Belo Horizonte: Universidade Federal de Minas Gerais.

SCHAFER, Armin e STREECK, Wolfgang, 2013. Politics in the Age of Austerity. Cambridge: Polity Press, 2013.

SCHUI, Florian, 2014. Austerity: the great failure. New Haven: Yale University Press, 2014.

SCHUKNECHT, Ludger, 2000. "Fiscal policy cycles and public expenditure in developing countries" in Public Choice, v. 102. Netherlands: Kluwer Academic Publishers, pp. 115-130. 
SICSU, João, 2007. Arrecadação (de onde vem?) e gastos públicos (para onde vão?). São Paulo: Boitempo editorial.

SILVA, Virgílio Afonso da, 2003. "Princípios e regras: mitos e equívocos acerca de uma distinção", in Revista Latino-Americana de Estudos Constitucionais 1, Belo Horizonte: Del Rey, 2003, pp. 607-630.

SILVEIRA, Ricardo e JORDÃO, Rafael, 2002. O comportamento das despesas estaduais com pessoal após a LRF. Rio de Janeiro: BNDES. Disponível em: <http://www.bndes.gov.br/SiteBNDES/export/sites/default/bndes_pt/Galerias/Arquivos/ conhecimento/informesf/inf_44.pdf>

SIMONASSI, A. G.; CANDIDO JUNIOR, J. O, 2008. Desempenho fiscal e os impactos sobre as responsabilidades fiscal e social nos Estados e regioes brasileiras. Brasilia: IPEA.

SINGER, Andre, 2012. Sentidos do lulismo. São Paulo: Companhia das Letras.

SOARES, Cristiano, CERETTA, Paulo, CORONEL, Daniel, VIEIRA, Kelmara, 2012. "A lei de reponsabilidade fiscal e o comportamento do endividamento dos Estados brasileiros: uma análise de dados em painel de 2000 a 2010", trabalho apresentado em Encontro de Administração, Política e Governo, nov. 2012. Disponível em:

<http://www.anpad.org.br/diversos/trabalhos/EnAPG/enapg_2012/2012_EnAPG507.pd f>

SOLA, Lourdes e WHITEHEAD, Lawrence, 2006. Statecrafting monetary authority: democracy and financial order in Brazil. Oxford: Centre for Brazilian Studies.

TAVARES, Martus, 2005. "Vinte anos de política fiscal no Brasil: dos fundamentos do novo regime à Lei de Responsabilidade Fiscal.” Revista de Economia e Relações Internacionais, vol. 4, nº 7, Julho de 2005, pp. 79-101.

TAYLOR, Matthew M., 2009. "Institutional development through policy-making: a case study of the Brazilian Central Bank", in World Politics, volume 61, Number 3, pp. 487-515.

TEIXEIRA, Anderson e VELOSO, Gilberto, 2007. “A Lei de Responsabilidade Fiscal e as microrregiões do Estado do Rio Grande do Sul: uma análise empírica" in Ensaios FEE, v. 28, n. 2, oct. 2007, pp. 443-470. Porto Alegre.

TEUBNER, Gunther, 2011. "A constitutional moment? The logics of 'hitting the bottom'”, in Gunther Teubner, Alberto Febbrajo and Poul F. Kjaer, The financial crisis 
in constitutional perspective: the dark side of functional differentiation, Oxford, Hart Publishing, $\quad$ p. 3-42. Disponível em: $<$ http://www.jura.unifrankfurt.de/1_Personal/em_profs/teubner/Person_englisch/Publika Engl/index.html>

TCU, 2014. Relatório das contas do Governo da República. Brasília: Tribunal de $\begin{array}{llll}\text { Contas da } & \text { União. }\end{array}$ $<$ http://portal2.tcu.gov.br/portal/page/portal/TCU/comunidades/contas/contas_governo/ Contas2013/index.html>

UNGER, Roberto Mangabeira; LOTHIAN, Tamara, 2011. Crisis, Slump, Superstition and Recovery Thinking and acting beyond vulgar Keynesianism, disponível em: 〈http://www.law.harvard.edu/faculty/unger/economics.php\#1>

VASCONCELOS, Natália Pires de, 2010. O supremo tribunal federal e o orçamento: uma análise do controle concentrado de leis orçamentárias. São Paulo: Sociedade Brasileira de Direito Público. Disponível em: <http://www.sbdp.org.br/arquivos/monografia/161_Monografia\%20Natalia\%20Pires.pd f>

VEIGA DA ROCHA, Jean-Paul, 2011. “Autonomia e accountability no sistema financeiro: notas para uma agenda de pesquisa jurídica" in Revista de Direito Público da Economia, v. 33, p. 95-112, 2011

VON HAGEN, Jurgen e HARDEN, Ian, 1996. "Budgeting processes and Commitment to Fiscal Discipline" IMF Working Paper.

VON HAGEN, Jurgen, 1992. "Budgeting Procedures and Fiscal Performance in the European Communities", in European Economy Economic Papers $n^{\circ} 96$. Comission of European Communities.

VREELAND, James, 2004. "The international and domestic politics of IMF Programs". Artigo apresentado na conferência: Reinventing Bretton Woods Committee and World Economic Forum on the Fund's Role in Emerging Markets: reassessing the adequacy of its resources and lending facilities. Amsterdam: Novembro de 2004.

VREELAND, James, 2007. The International Monetary Fund: politics of conditional lending. New York: Routledge.

WILLIAMSON, John, 1990. "What Washington means by policyreform" in J. Williamson, ed., Latin American Adjustment: How Much Has Happened? Washington: Institute for International Economics. 
WOO, Jaejoon, 2001. Economic, political, and institutional determinants of public debt. Disponível em: <http://ssrn.com/abstract=326520> ou <http://dx.doi.org/10.2139/ssrn.326520>

\section{Decisões Judiciais}

BRASIL, 1984. $5^{\text {a }}$ Vara da Justiça Federal de Brasília. Ação Popular. Número original: 230-AD184. Atual número do processo: 0001274-78.1984.4.01.3400.

BRASIL, 2003. Supremo Tribunal Federal. Ação Direta de Inconstitucionalidade $\mathrm{n}^{\circ}$ 2250. Julgamento da medida cautelar na Ação Direta de Inconstitucionalidade. Publicado no DJ de 01 de agosto de 2003.

BRASIL, 2008. Supremo Tribunal Federal. Ação Direta de Inconstitucionalidade $n^{\circ}$ 2238. Julgamento da medida cautelar na Ação Direta de Inconstitucionalidade. Publicado no DJe de 12 de setembro de 2008. Processos apensados: Ações Diretas de Inconstitucionalidade n 2256, 2241, 2261 e 2365.

BRASIL, 2009. Supremo Tribunal Federal. Recurso Extraordinário nº 537.610. Publicado no DJe de 18 de dezembro de 2009. 


\section{Anexo I - Metodologia das pesquisas utilizadas na seção 4.1.}

Corbari e Macedo (2009) empregam dois modelos econométricos para testar a seguinte hipótese: “o endividamento dos municípios brasileiros com mais de 100 mil habitantes foi influenciado pela Lei de Responsabilidade Fiscal". Os autores usam os dados disponibilizados pelo banco de dados Finanças do Brasil (FINBRA) a respeito de 248 municípios, excluídos 124 municípios que não tinham dados orçamentários, financeiros e/ou patrimoniais para todo o período e 13 municípios com mais de um milhão de pessoas, no período entre 1998 e 2006. Os autores tentam capturar o efeito da Lei nos seguintes indicadores da gestão financeira sobre o endividamento municipal ${ }^{189}$, antes e depois de 2001, ano no qual se supõe que a Lei de Responsabilidade Fiscal tenha passado a surtir efeito nesses indicadores: (i) estrutura de capital - parcela do passivo total proveniente de terceiros; (ii) liquidez - parcela das obrigações que se pode saldar com as disponibilidades; (iii) grau de dependência - relação entre as receitas de transferência (do Estado e da União) e a receita total do município; (iv) despesa de pessoal - parcela das receitas correntes comprometidas com despesa de pessoal; (v) despesa de investimento - em relação à receita corrente líquida; (vi) endividamento defasado - endividamento do exercício anterior como variável explicativa do endividamento corrente; (vii) variáveis dummies de tempo.

Linhares, Penna e Borges (2013) usam a mesma metodologia de Corbari e Macedo (2009) para analisar os dados de 83 municípios do estado do Piauí no período entre 1998 e 2007, disponibilizados pelo FINBRA.

Alves e Santos (2011) utilizam um modelo de regressão para testar a hipótese de que a Lei de Responsabilidade Fiscal impactou os indicadores de: (i) créditos adicionais - alterações anuais orçamentárias em relação ao orçamento inicialmente aprovado; (ii) realização da receita orçamentária - que corresponde à receita total realizada pela receita total orçada; (iii) execução orçamentária corrente - capacidade de manter despesas correntes por meio das receitas correntes do mesmo período; (iv) realização da receita tributária - pressão tributária exercida sobre a riqueza econômica dos municípios; (v) investimentos - capacidade de realizar investimentos em relação ao PIB local; (vi) resultado primário - capacidade de pagamento do estoque da dívida; (vii) operações de crédito - montante das operações na composição das despesas de

\footnotetext{
${ }^{189}$ Mensurado pela quantidade de Receita Corrente Líquida necessária para quitar o montante das dívidas de curto e longo prazo.
} 
capital. O PIB municipal foi a variável de controle, uma vez que os indicadores se relacionam com o PIB. Os autores tiveram como universo de pesquisa os dados de 419 dos 496 municípios do estado do Rio Grande do Sul, no período entre 1997 e 2004, excluídos aqueles que tiveram alteração territorial. Os dados usados provieram do banco de dados do Tribunal de Contas do Estado do Rio Grande do Sul e do IBGE.

Gadelha (2011) também usa modelo econométrico para testar o impacto da Lei de Responsabilidade Fiscal no comportamento fiscal dos municípios brasileiros por meio de dois indicadores: despesa de pessoal em relação à receita corrente e receita tributária em relação à receita corrente. O universo analisado são os dados de 5.592 municípios brasileiros, no período entre 1995 e 2009, disponibilizados pelo FINBRA.

Santolin, Jayme Jr. e Reis (2009) buscam identificar os efeitos da Lei de Responsabilidade Fiscal em diferentes categorias de despesas de municípios mineiros. O universo de análise foi composto por dados de 853 municípios mineiros entre o período de 1995 e 2005, disponibilizados pelo FINBRA, excluídos os municípios de Belo Horizonte, Contagem, Uberlândia, Juiz de Fora, Betim e Montes Claros por serem os únicos com estimativas populacionais acima de 300.000 mil habitantes. Os autores realizaram regressões econométricas para dois grupos de municípios: com população abaixo de 50 mil habitantes (790 municípios); com população entre 50 e 300 mil habitantes (57 municípios).

Sakurai (2005) testa duas variáveis fiscais e três variáveis políticas para avaliar como elas impactam a capacidade de os municípios paulistas obterem resultado primário positivo ou negativo. As variáveis fiscais são as razões entre despesa de pessoal/receita corrente e receita tributária/receita corrente. As variáveis políticas são os índices de fracionalização das preferências do eleitorado; o partido do prefeito ou da prefeita municipal; e a similaridade entre o partido do prefeito e do governador. Variáveis dummies de tempo também foram adotadas. O universo de análise corresponde aos dados de 572 municípios do estado de São Paulo no período entre 1989 e 2001, obtidos junto à Fundação Seade e junto ao Tribunal Regional Eleitoral de São Paulo.

Fioravante, Pinheiro e Vieira (2006) analisam o impacto da Lei de Responsabilidade Fiscal em duas variáveis: dívida consolidada líquida e despesa com pessoal. Os autores também usam os dados municipais disponibilizados pelo FINBRA, entre o período de 1998 e 2004, excluídos os municípios que não possuíam dados para pelo menos um daqueles anos. 
Menezes (2006) testa os efeitos da Lei de Responsabilidade Fiscal sobre as categorias e funções de despesas dos municípios brasileiros entre 1998 e 2004. Para isso, Menezes usa diferentes modelos econométricos e combina a variável da Lei de Responsabilidade Fiscal com as seguintes variáveis políticas: partido da União e partido estadual - diz respeito à eventual correspondência entre o partido do prefeito e dos chefes do executivo estadual e federal; partido de esquerda ou direita - partidos de esquerda tenderiam a gastar mais segundo o modelo; partidos efetivos - grau de diversificação de partidos nas Assembleias; competição - número de candidatos por número de vagas na Câmara; e população. $\mathrm{O}$ autor segue a classificação por funções de destinação por despesas em (i) social, (ii) overhead - despesas administrativas -, (iii) infraestrutura e (iv) outras, enquanto as categorias de despesas seguiram a estrutura contábil (despesa corrente e despesa de capital) adotada pelos municípios. O universo de análise são os dados provenientes do FINBRA e do Tribunal Superior Eleitoral, no caso de algumas variáveis políticas.

De modo semelhante, Araújo, Chieza e Silva Jr. (2009) testam os efeitos da Lei de Responsabilidade Fiscal sobre as categorias e funções das despesas dos municípios no período entre 1997 e 2004, mas limitando-se aos municípios do Rio Grande do Sul. Os dados fiscais analisados, contudo, provêm do Tribunal de Contas do Estado, e os dados populacionais e de natureza política, da Fundação de Economia e Estatística e do Tribunal Regional Eleitoral, respectivamente. As categorias e as funções das despesas são as mesmas que foram adotadas por Menezes. As variáveis fiscais para a construção do modelo são: despesa total, despesa com pessoal, outras despesas correntes, despesas de capital, superávit/déficit e receita total. As variáveis políticas são: competição por vagas no Legislativo, de acordo com a proporção entre número de candidatos e número de vagas; índice de participação dos eleitores, que corresponde à divisão entre o número de votantes e o número de eleitores; e o índice de fragmentação partidária, que mede a dispersão/concentração de vagas por partido no Legislativo municipal.

Giuberti (2005) se foca no impacto da Lei de Responsabilidade Fiscal sobre o gasto com pessoal e busca averiguar se a lei impactou o número de municípios que, no período entre 1997 e 2003, desrespeitavam o teto estabelecido pela lei de $60 \%$ de despesa com pessoal em relação à receita líquida corrente. A pesquisa também utiliza os dados do FINBRA. As demais variáveis utilizadas no modelo foram: parcela da receita corrente oriunda de transferências da União e do município; número de pessoas residentes no município; taxa de inflação; número de partidos efetivos com 
representação; fracionalização das preferências dos eleitores; grau de polarização da Câmara Municipal e ideologia do partido.

Ceretta, Coronel, Soares e Vieira (2012) apresentam um modelo econométrico que busca mensurar o impacto da Lei de Responsabilidade Fiscal sobre o endividamento dos estados. O universo de pesquisa foram os dados de 26 estados brasileiros disponibilizados no portal da STN pelo período de 2000 a 2010. Os dados relativos ao Distrito Federal não foram computados. O modelo tenta compreender se a razão entre dívida consolidada líquida e receita corrente líquida foi alterada pelas seguintes variáveis: Lei de Responsabilidade Fiscal, PIB per capita, taxa de juros, despesas de investimento, inflação (medida pelo IPCA), eleições, grau de dependência financeira dos estados (mensurada pela razão entre os recursos transferidos pela União e a receita total dos Estados) e resultado primário anual.

Rocha e Rocha (2008) tentam compreender quais variáveis podem explicar a duração de ajustes fiscais estaduais acima de $0,5 \%$ do PIB estadual no período entre 1986 e 2001. Os autores usaram dois conjuntos de variáveis para fazer seus estudos: variáveis estruturais, que são econômicas e institucionais; variáveis políticas. No primeiro conjunto de variáveis, encontram-se: despesa de pessoal/ receita corrente líquida; grau de dependência dos Estados de transferências de receitas da União; força da consolidação fiscal (mudança no saldo fiscal); número de falhas em tentativas de ajustes fiscais anteriores; qualidade do ajustamento, que mede a importância da redução dos gastos e do aumento de impostos para a consolidação (redução de despesas representa situação de melhora); variável dummy para a Constituição Federal de 1988; variável dummy para a Lei 9.496/97, a lei que reestruturou as dívidas estaduais; variável dummy para anos eleitorais. As variáveis políticas do modelo são: fracionalização das preferências; polarização da coligação; partidos efetivos na composição da Assembleia Legislativa; partidos de esquerda; indicador de permanência no poder como uma proxy para a probabilidade de reeleição (de acordo com o argumento de que se o partido não tiver a perspectiva de ser reeleito ele provavelmente gastará mais).

Cândido Júnior e Simonassi (2008) também fazem uso de modelo econométrico para descrever os impactos de ciclos políticos e regras jurídicas sobre os níveis de gasto público com pessoal/receita líquida estadual, no período entre 1985 e $2002 .{ }^{190}$ Os

\footnotetext{
${ }^{190}$ A pesquisa também investiga uma possível existência de um trade-off entre responsabilidade fiscal, mensurada por meio dos níveis de gasto público com pessoal/receita líquida estadual, e responsabilidade social, mensurados como investimentos em três grandes áreas: educação e saúde; segurança pública;
} 
autores excluíram Roraima, Tocantins e Distrito Federal da análise. As variáveis analisadas foram: dummies para anos eleitorais e pré-eleitorais; dummies para o processo de renegociação das dívidas estaduais, para a emenda da reeleição e para a Lei de Responsabilidade Fiscal. Os autores usaram os dados disponibilizados pela Secretaria do Tesouro Nacional.

Rocha e Giuberti (2008) estudam se a política fiscal dos estados brasileiros foi anticíclica e simétrica (ou seja, aumentos de déficit em período de depressão são compensados em períodos de expansão econômica) no período entre 1997 e 2004 e como a Lei de Responsabilidade Fiscal atuou nesses dois âmbitos. Todos os dados foram obtidos junto à Secretaria do Tesouro Nacional. No modelo econométrico das autoras, para explicar o resultado primário estadual, testam-se as seguintes variáveis: resultado positivo do PIB estadual; resultado negativo do PIB; comportamento do PIB nacional; dívida consolidada defasada; saldo primário defasado; e a Lei de Responsabilidade Fiscal como variável dummy.

Nakaguma e Bender (2006) apresentam estudo sobre os efeitos da Lei de Responsabilidade Fiscal e da Emenda da Reeleição sobre diversas variáveis fiscais. Para isso, as variáveis independentes do modelo foram: defasagens da variável dependente; ciclo eleitoral, composto por um conjunto de três variáveis dummies - ano pré-eleitoral; ano eleitoral; ano pós-eleitoral; variável a emenda da reeleição; variável para a Lei de Responsabilidade Fiscal; taxa de variação do PIB nacional; variável de ideologia partidária; variável para identificar onde houve eleições de segundo turno. Os dados das variáveis fiscais foram obtidos na Secretaria do Tesouro Nacional e os dados das variáveis políticas no Laboratório de Estudos Experimentais (LEEX) do Instituto Universitário de Pesquisas do Rio de Janeiro.

Silveira e Jordão (2002) realizam pesquisa mensurando a evolução dos gastos de pessoal em todos os poderes de 14 estados da União que tinham dados para os anos de 1998 e 2001. Os dados utilizados foram apresentados pelas secretarias estaduais da fazenda em 1998, à época da propositura da Lei de Responsabilidade Fiscal para o Congresso pelo Executivo, e coletados junto a tribunais de conta estaduais. Os autores ainda usaram informações de seis estados que tinham dados disponibilizados em 2001 junto aos tribunais de contas estaduais.

infraestrutura. $\mathrm{O}$ argumento dos autores é o de que se há o trade-off, um maior esforço fiscal reduziria os gastos nessas áreas de "responsabilidade social". Os autores não encontram a existência do referido tradeoff. 


\section{Anexo II - Pedidos de acesso à informação}

\section{Pedido I - Banco Nacional de Desenvolvimento Econômico e Social}

Dados do Pedido

Protocolo

Solicitante

Data de abertura

Orgão Superior Destinatário

Orgão Vinculado Destinatário

Prazo de atendimento

Situação

Status da Situação

Forma de recebimento da resposta Pelo sistema (com avisos por email)

Resumo

Detalhamento

\section{Dados da Resposta}

Data de resposta

$10 / 03 / 201417: 48$
99903000103201477

Flavio Marques Prol

14/02/2014 14:06

BNDES - Banco Nacional de Desenvolvimento Econômico e Social

$10 / 03 / 2014$

Respondido

Acesso Concedido (Informações enviadas por e-mail)

\section{Prezada/o,}

Meu nome é Flávio Marques Prol e estou realizando uma pesquisa de Mestrado sobre a aprovação da Lei de Responsabilidade Fiscal. Sabe-se que entre 1998 e 1999 o BNDES foi um dos responsáveis por publicar e organizar uma discussão pública do anteprojeto de Lei Complementar da Responsabilidade Fiscal.

Segundo informações públicas, o anteprojeto contou com mais de 5000 comentários enviados pela internet no período, além de terem sido realizadas reuniões entre órgãos do governo federal e dos governos estaduais e municipais, entre outros.

Até 2006/2007, algumas dessas informações podiam ser encontradas no portal http://federativo.bndes.gov.br . Contudo, o portal não está mais ativo e não temos mais acesso a essas informações.

Nesse sentido, venho por meio desse pedido requerer os seguintes documentos:

(i) íntegra do anteprojeto de Lei Complementar da Responsabilidade Fiscal publicada e disponibilizada para consulta pública;

(ii) quantidade e data das reuniões/encontros organizadas pelo BNDES para discussão do anteprojeto e para consolidação dos comentários;

(iii) membros que participaram dessas reuniões;

(iv) se possível, as atas dessas reuniões;

(v) todos os documentos que estavam disponíveis no portal de internet supra referido.

Muito obrigado pela atenção,

Flávio 
Tipo de resposta

Classificação do Tipo de resposta

Resposta

\section{Classificação do Pedido}

Categoria do pedido

Economia e Finanças

Subcategoria do pedido

Economia

Acesso Concedido

Número de perguntas

Informações enviadas por e-mail

Prezado Flavio Marques Prol,

Em atenção ao seu pedido de informação n ${ }^{\circ} 99903000103201477$, esclarecemos que é possível consultar o site do Banco Federativo, através do link ao lado, e que não foram encontrados outros registros sobre o tema, além dos disponíveis no link indicado.

Informamos que esta demanda será encerrada no e-SIC e que, no caso de negativa de acesso à informação ou de não fornecimento das razões da negativa de acesso, poderá ser apresentado recurso ao Comitê da Lei de Acesso à Informação do BNDES, no prazo de dez dias, contados da ciência da decisão.

Atenciosamente

Serviço de Informação ao Cidadão

BNDES

\section{Pedido II - Ministério da Fazenda}

\section{Dados do Pedido}

Protocolo

Solicitante

Data de abertura

Orgão Superior Destinatário

Orgão Vinculado

Destinatário

Prazo de atendimento

Situação

Status da Situação

Forma de recebimento da resposta

Resumo

Detalhamento
16853000194201456

Flavio Marques Prol

31/01/2014 18:07

MF - Ministério da Fazenda

$24 / 02 / 2014$

Respondido

Acesso Parcialmente Concedido (Parte do pedido é genérico)

Pelo sistema (com avisos por email)

Prezada/o,

Meu nome é Flávio Prol e estou realizando uma pesquisa de mestrado sobre reformas legais que ocorreram no final da década de 1990 no 
que diz respeito à administração das finanças públicas.

Até o ano passado, o site do Ministério da Fazenda disponibilizava eletronicamente os documentos do Programa de Estabilidade Fiscal, no seguinte endereço:

http://www.fazenda.gov.br/portugues/ajuste/pef98.asp

Contudo, os documentos não estão mais disponíveis. Gostaria, por gentileza, de ter acesso a tais documentos.

Também gostaria de ter acesso aos arquivos que o Ministério possui relativos às reuniões que ocorreram entre 1997 e 1999 entre Fundo Monetário Internacional e as autoridades do Ministério da Fazenda. Até o ano passado o site também disponibilizava alguns desses documentos.

Em particular, gostaria de ter acesso a todas as cartas enviadas pelo então Ministro Pedro Malan ao FMI, além da confirmação da quantidade de reuniões realizadas entre Ministério da Fazenda e FMI e, se possível, as atas das respectivas reuniões.

Muito obrigado pela atenção, Flávio

\section{Dados da Resposta}

Data de resposta

Tipo de resposta

Classificação do Tipo de resposta

Resposta

Anexo

\section{$21 / 02 / 201409: 34$}

Acesso Parcialmente Concedido

Parte do pedido é genérico

Prezado Senhor,

Encaminhamos em anexo resposta ao pedido de informação.

Considerando o disposto no art. 19, inc. II, c/c o art. 21, caput, do Decreto n. ${ }^{\circ} 7.724$, de 2012, informa-se que poderá ser apresentado recurso, no prazo de 10 dias, contado da ciência da decisão.

Autoridade responsável pela apreciação do recurso: Chefe da Assessoria Técnica e Administrativa do GMF.

Atenciosamente,

Serviço de Informação ao Cidadão

Ministério da Fazenda

Memorando ${ }^{\circ}$ 9/201 4/COATI/ASTEC/GMF/MF-DF

Em 18 de fevereiro de 2014.

Ao Senhor Ouvidor-Geral do Ministério da Fazenda

Carlos Augusto Moreira Araujo

Assunto: Pedido de Informação - Órgãos Singulares - Resposta ao SIC 16853000194201456

1. Em atenção ao Pedido de Informação SIC-MF, protocolo ${ }^{\circ}$ 6853000194201456 ,

de autoria do cidadão Flávio Marques Prol, esclareço:

a) quanto ao acesso aos documentos disponibilizados por meio do endereço eletrônico 
http://www.fazenda.gov.br/portugues/ajuste/peJ98.asp, informa-se que não há previsão de o referido link ser reativado; porém, informações sobre política fiscal estão disponíveis no sítio da Secretaria do Tesouro Nacional (https://www.tesouro.fazenda.gov.br);

b) quanto aos demais itens do pedido: acesso aos arquivos relativos às reuniões que ocorreram entre 1997 a 1999 entre o FMI e as autoridades do MF, acesso a todas as cartas enviadas pelo então Ministro Pedro Malan ao FMI, além da confirmação da quantidade de reuniões realizadas entre MF e FMI e, se possível, as atas das respectivas reuniões, informa-se sobre a impossibilidade de atendimento do pedido nos termos do inciso 1 do artigo 13 do Decreto $\mathrm{n}^{\circ} 7.724 / 2012$, por se tratar de pedido genérico.

Atenciosamente,

\section{Classificação do Pedido}

Categoria do pedido

Subcategoria do pedido

Número de perguntas
Economia e Finanças

Finanças

\section{Histórico do Pedido}

\begin{tabular}{|l|l|l|}
\hline Data do evento & Descrição do evento & Responsável \\
\hline 31/01/2014 18:07 & $\begin{array}{l}\text { Pedido Registrado para o Órgão MF - } \\
\text { Ministério da Fazenda }\end{array}$ & SOLICITANTE \\
\hline 03/02/2014 14:44 & Pedido em Atendimento & MF - Ministério da Fazenda \\
\hline 21/02/2014 09:34 & Pedido Respondido & MF - Ministério da Fazenda \\
\hline 24/02/2014 13:55 & Recurso de 1a. instância registrado & SOLICITANTE \\
\hline 06/03/2014 18:01 & Recurso de 1a. instância respondido & MF - Ministério da Fazenda \\
\hline
\end{tabular}

\section{Dados do Recurso de $\mathbf{1}^{\text {a }}$ Instância}

Órgão Superior Destinatário

Órgão Vinculado Destinatário

Data de Abertura

Prazo de Atendimento

Tipo de Recurso
MF - Ministério da Fazenda

24/02/2014 13:55

$06 / 03 / 2014$

Grau de classificação inexistente

\section{Justificativa}

Prezada/o,

Em resposta ao pedido de informações por mim solicitado, o senhor Abrahão Medeiros de Alencar, Coordenador de Análise Técnica e Informação do GMF respondeu:

"1. [...] a) quanto ao acesso aos documentos disponibilizados por meio de endereço eletrônico http://www.fazenda.gov.br/portugues/ajuste/pef98.asp, informa-se que não há previsão de o referido link ser reativado; porém, informações sobre política fiscal estão disponíveis no sítio da Secretaria 
do Tesouro Nacional (https://www.tesouro.fazenda.gov.br)

b) quanto aos demais itens do pedido: [...], informa-se sobre a impossibilidade de atendimento do pedido nos termos do inciso I do artigo 13 do Decreto $\mathrm{n}^{\circ} 7.724 / 2012$, por se tratar de pedido genérico".

Ambas as alegadas justificativas são improcedentes, senão vejamos.

a) Sobre o pedido de acesso aos documentos disponibilizados por meio de endereço eletrônico:

Em primeiro lugar, o fato de não haver previsão de o link ser reativado não implica a inexistência dos documentos e das informações solicitadas. Pelo contrário, espera-se que documentos que até recentemente estavam disponibilizados eletronicamente pelo governo tenham sua contraparte real, até porque se tratavam de documentos públicos sobre política pública criada e gerida por este Ministério da Fazenda. Nesse sentido, não há justificativa para negativa de acesso aos documentos.

Em segundo lugar, é de conhecimento público que o referido sítio existiu - como a própria resposta o afirma - e que os documentos estavam disponíveis. Basta a realização de uma busca na base de dados da homepage do Ministério para (i) reativar o site com as informações de interesse público ou (ii) ao menos enviar para o cidadão que solicita as informações até então disponibilizadas.

Por fim, o fato de o sítio da Secretaria do Tesouro Nacional disponibilizar certas informações sobre política fiscal não guarda qualquer relação com o conteúdo do pedido de acesso, a não ser que as informações ainda estivessem disponibilizadas, o que não ocorre.

Por fim, as informações até então disponibilizadas não têm caráter sigiloso e, portanto, não podem ser negadas ao cidadão, sob pena das sanções legais cabíveis.

b) Sobre o pedido de acesso aos arquivos relativos às reuniões que ocorreram entre 1997 a 1999 entre o FMI e as autoridades do MF, acesso a todas as cartas enviadas pelo então Ministro Pedro Malan ao FMI, além da confirmação da quantidade de reuniões realizadas entre MF e FMI e, se possível, as atas das respectivas reuniões:

Em primeiro lugar, a resposta a esse pedido depende da definição de pedido genérico. O senhor Abrahao afirma que o pedido de acesso foi genérico, nos termos do decreto que sanciona a lei. $\mathrm{Na}$ definição encontrada no dicionário Priberam, genérico é "o que é tratado na generalidade, sem especificidades ou pormenores".

De acordo com a linguagem denotativa, portanto, o pedido definitivamente não é genérico. Pelo contrário, é um pedido específico em relação a três fatores: tempo, espaço e agentes. No que diz respeito às reuniões e às cartas, as especificidades são: (i) no tempo - entre os anos de 1997 e 1999; (ii) no espaço - reuniões efetivamente realizadas entre determinados agentes; (iii) quanto aos agentes - entre FMI (e seus representantes) e o então ministro da Fazenda (ou pessoas representando-o).

Dentre as informações públicas disponíveis, o pedido foi o mais específico que se poderia ser.

Ademais, a construção do que se entende por genérico depende de como o agente responsável pela implementação da norma interpreta o comando normativo. Nesse caso, a justificação é completamente inexistente. Simplesmente se afirma: "é impossível, porque é genérico." Ora, isso não é justificativa. A não ser que tivéssemos algum conceito de "genérico" auto evidente e imediato, esse tipo de resposta seria possível. Mas esse claramente não é o caso aqui.

Não se trata de pedido impossível ou de difícil verificação: o que um cidadão dessa República Federativa do Brasil solicita são informações existentes de autoridades que o representam (eleitas ou não). Essas informações, no presente caso, estão disponíveis na agenda oficial do Ministro (que se espera que o Ministério esteja arquivando, para conferência posterior de qualquer cidadão interessado) e de atas de reuniões realizadas pela autoridade máxima do órgão com uma determinada entidade supranacional.

Mais uma vez, por evidente, a informação não foi classificada como sigilosa, o que demonstra o 
cabimento e a procedência do pedido.

\section{Conclusão}

A lei de acesso à informação foi criada para garantir acesso a um direito fundamental de todas cidadãs e de todos cidadãos: o direito a informação. Em um caso como esse, a autoridade administrativa não pode tratar o caso como se estivesse falando com um inferior ou com qualquer subordinado. Devem existir justificativas fortes o suficiente para efetivamente determinar um resultado favorável ou não ao pedido de acesso. As razões, no Estado Democrático de Direito, vinculam. E, nesse caso, as razões da autoridade para a negativa de acesso são insuficientes, quando não inexistentes.

As informações às quais se requer acesso existem. A própria resposta confirma sua existência. Considerando que elas são de fácil acesso pelas autoridades, presentes em banco de dados do sítio do ministério ou sendo possível de serem recuperadas a partir da disponibilização da agenda de um ex-ministro durante um determinado período de tempo e das eventuais atas das reuniões das quais participou, além das cartas oficialmente enviadas pelo mesmo período a determinado organismo internacional, exige-se a sua disponibilização.

O exercício desse direito fundamental faz parte da construção de uma democracia na qual os cidadãos efetivamente participam do controle das deliberações que dizem respeito ao interesse público.

Nesse sentido, com base nos artigos $7^{\circ}$ e 15 da Lei 12.527/2011, requer-se a reforma da decisão tomada sem justificativa substantiva, para determinar o acesso às seguintes informações:

(i) documentos até recentemente disponibilizados por meio do endereço eletrônico http://www.fazenda.gov.br/portugues/ajuste/peJ98.asp. Como se sabe, esses documentos reproduziam eletronicamente os documentos produzidos no âmbito do Programa de Estabilidade Fiscal anunciado pelo Ministério da Fazenda e pelo governo federal no dia 28 de outubro de 1998 e contemplam, dentre outros, a justificativa do programa, os discursos feitos pelo Presidente e pelo então Ministro da Fazenda para justificar o programa, um documento explicando os diversos níveis do Programa.

(ii) acesso aos arquivos relativos às reuniões que ocorreram entre 1997 a 1999 entre o FMI e as autoridades do MF, acesso a todas as cartas enviadas pelo então Ministro Pedro Malan ao FMI no período, além da confirmação da quantidade de reuniões realizadas entre MF e FMI e, se possível, as atas das respectivas reuniões.

Negar acesso a tais documentos públicos é um desserviço à democracia brasileira e ao conhecimento histórico de fatos relevantes para a construção da democracia no país.

Att.,

Flávio Marques Prol

Resposta Recurso

Data da Resposta

06/03/2014 18:01

Prazo Limite para Recurso

$17 / 03 / 2014$

Prazo para Disponibilizar

Informação

Tipo Resposta

Parcialmente deferido

Justificativa

Prezado Senhor,

Encaminhamos em anexo resposta ao recurso interposto ao Gabinete do Ministro da Fazenda 
Considerando o disposto no art. 19, inc. II, c/c o art. 21, caput, do Decreto n. ${ }^{\text {o }}$ 7.724, de 2012, informa-se que poderá ser apresentado recurso, no prazo de 10 dias, contado da ciência da decisão. Autoridade responsável pela apreciação do recurso:Chefe de Gabinete Substituto Ernani César e Silva Cabral.

Atenciosamente,

Serviço de Informação ao Cidadão

Ministério da Fazenda

Anexo

RESPOSTA AO RECURSO DE V INSTÂNCIA

SIC n2 16853000194201456

O Sr. Flávio Marques Prol interpôs recurso em face da decisão emanada do Coordenador de Análise Técnica e Informação do Gabinete do Ministério da Fazenda, nos termos do art. 15 da Lei n2 12.527/2011 e do art. 21 do Decreto no 7.724/2012. O recorrente alega que as justificativas apontadas pela autoridade "a quo" são improcedentes, razão pela qual requer a reforma da decisão para que tenha acesso (i) aos documentos até recentemente disponibilizados por meio do endereço eletrônico http://www.fazenda.gov.br/portugues/aiuste/pef98.asp e (ii) aos arquivos relativos às reuniões que ocorreram entre 1997 a 1999 entre o FMI e as autoridades do Ministério da Fazenda.

Em relação ao pedido "i” do recurso, comunico que as informações do Programa de Estabilidade Fiscal foram recuperadas da base de dados do Ministério da Fazenda e seguem anexas.

No que tange ao pedido "ii" da peça recursal, reitero a fundamentação da decisão recorrida e esclareço que o pleito carece de especificidade que permita à Administração Pública a correta identificação da informação a ser disponibilizada, assumindo, portanto, caráter de pedido genérico.

A Controladoria-Geral da União, em casos análogos ao ora examinado (cf. processos n $16853.0076172012-05 ; 16853.0076152012-16$; $16853.0076182012-41 ; 16853.0076162012-52$ ) e à luz do Decreto 7.724/2012, abordou o conceito de pedido genérico determinando expressamente a obrigatoriedade do demandante em delimitar de forma clara e precisa seu requerimento de informação, para que seja possível sua apreciação, de modo que "a imprecisão do pedido genérico impossibilita que a Administração Pública diligencie no sentido de satisfazer a demanda do requerente, tornando impossível, do ponto de vista fático, o atendimento ao pedido".

Assim, o pedido deve ser específico e, de acordo com o entendimento extraído da Administração Pública e da experiência internacional, deverá conter principalmente o assunto do registro solicitado de forma individualizada e, de forma complementar, a listagem dos documentos que sirvam de suporte à informação, o que não se verificou no caso concreto. Portanto, defiro o pedido contido no item "i" e encaminho as informações do Programa de Estabilidade Fiscal recuperadas da base de dados do Ministério da Fazenda, assim como julgo que os pedidos contidos no item "ii" do recurso não são específicos, seja porque não fornecem o assunto objeto das solicitações, seja porque não indicam a listagem dos documentos que servem de suporte à informação pleiteada, motivo pelo qual incide o óbice previsto no inciso 1 do art. 13 do Decreto n2 7.724/2012.

\section{Pedido III - Casa Civil/posteriormente encaminhado ao Ministério da Fazenda


Protocolo

Solicitante

Data de abertura

Orgão Superior Destinatário

Orgão Vinculado Destinatário

Prazo de atendimento

Situação

Status da Situação

Forma de recebimento da resposta

Resumo

Detalhamento

\section{Dados da Resposta}

Data de resposta

28/03/2014 15:29

Tipo de resposta

Classificação do Tipo de resposta

Resposta

07/04/2014

Respondido

Prezada/o, documentos: comentários;

Flávio
00077000173201448

Flavio Marques Prol

14/02/2014 14:02

MF - Ministério da Fazenda

Acesso Concedido (Resposta solicitada inserida no e-SIC)

Pelo sistema (com avisos por email)

Meu nome é Flávio Marques Prol e estou realizando uma pesquisa de Mestrado sobre a aprovação da Lei de Responsabilidade Fiscal. Sabe-se que entre 1998 e 1999 a Casa Civil foi responsável por publicar e organizar uma discussão pública do anteprojeto de Lei Complementar da Responsabilidade Fiscal.

Segundo informações públicas, o anteprojeto contou com mais de 5000 comentários enviados pela internet no período, além de terem sido realizadas reuniões entre órgãos do governo federal e dos governos estaduais e municipais, entre outros.

Até 2006/2007, algumas dessas informações podiam ser encontradas no portal http://federativo.bndes.gov.br . Contudo, o portal não está mais ativo e não temos mais acesso a essas informações.

Nesse sentido, venho por meio desse pedido requerer os seguintes

(i) íntegra do anteprojeto de Lei Complementar da Responsabilidade Fiscal publicada e disponibilizada para consulta pública;

(ii) quantidade e data das reuniões/encontros organizadas pela Casa Civil para discussão do anteprojeto e para consolidação dos

(iii) membros que participaram dessas reuniões;

(iv) se possível, as atas dessas reuniões;

(v) parecer jurídico do dr. Cid Heráclito de Queiroz, Procurador da Fazenda Nacional aposentado, que à época fundamentou a defesa da constitucionalidade do anteprojeto.

Muito obrigado pela atenção,

\section{Acesso Concedido}

Resposta solicitada inserida no e-SIC

Prezado Senhor, 
Em atenção ao requerimento formulado, cumpre-nos informar que a demanda foi encaminhada à Secretaria do Tesouro Nacional, que se pronunciou conforme abaixo:

"Informamos que a Secretaria do Tesouro Nacional não dispõe das informações solicitadas. As reuniões realizadas sobre o tema foram organizadas pela Casa Civil que provavelmente terá informações quanto aos participantes, atas das reuniões e o texto do anteprojeto. A discussão sobre a Lei de Responsabilidade fiscal também teve participação do Ministério do Planejamento. Quando à tramitação do Projeto no Congresso Nacional melhor seria uma consulta aos anais da Câmara dos Deputados e do Senado Federal e em relação às informações que constavam do sítio do BNDES estas poderão ser solicitadas ao Órgão. E por fim, no que se refere a parecer da PGFN seria o caso de solicitar diretamente àquela Procuradoria."

Atenciosamente,

Serviço de Informação ao Cidadão

Ministério da Fazenda

\section{Classificação do Pedido}

Categoria do pedido

Subcategoria do pedido

Número de perguntas
Economia e Finanças

Finanças

\section{Histórico do Pedido}

\begin{tabular}{|c|c|c|}
\hline Data do evento & Descrição do evento & Responsável \\
\hline $14 / 02 / 201414: 02$ & $\begin{array}{l}\text { Pedido Registrado para o Órgão CC-PR - } \\
\text { Casa Civil da Presidência da República }\end{array}$ & SOLICITANTE \\
\hline 17/02/2014 10:31 & Pedido em Atendimento & PR - Palácio do Planalto \\
\hline $10 / 03 / 201411: 55$ & Pedido Prorrogado & $\begin{array}{l}\text { PR - Palácio do Planalto/CC-PR - } \\
\text { Casa Civil da Presidência da } \\
\text { República }\end{array}$ \\
\hline 17/03/2014 18:41 & $\begin{array}{l}\text { Pedido Reencaminhado para o Órgão MF - } \\
\text { Ministério da Fazenda }\end{array}$ & $\begin{array}{l}\text { PR - Palácio do Planalto/CC-PR - } \\
\text { Casa Civil da Presidência da } \\
\text { República }\end{array}$ \\
\hline 28/03/2014 15:29 & Pedido Respondido & MF - Ministério da Fazenda \\
\hline
\end{tabular}




\section{Anexo III - Dados que geraram os gráficos}

\section{Gráfico 1: Comparação entre Dívida Consolidada Líquida e Receita Corrente Líquida}

\begin{tabular}{|c|c|c|c|c|c|c|c|c|c|c|c|c|c|c|}
\hline UF & & & & & & & Relação I & L/RCL & & & & & & \\
\hline & $31 / 12 / 00$ & $31 / 12 / 01$ & $31 / 12 / 02$ & $31 / 12 / 03$ & $31 / 12 / 04$ & $31 / 12 / 05$ & $31 / 12 / 06$ & $31 / 12 / 07$ & $31 / 12 / 08$ & $31 / 12 / 09$ & $31 / 12 / 10$ & $31 / 12 / 11$ & $31 / 12 / 12$ & $31 / 12 / 13$ \\
\hline $\mathrm{AC}$ & 1,04 & 0,83 & 0,73 & 0,68 & 0,62 & 0,45 & 0,52 & 0,41 & 0,28 & 0,37 & 0,54 & 0,5 & 0,58 & 0,69 \\
\hline $\mathrm{AL}$ & 2,23 & 1,78 & 2,36 & 2,77 & 2,64 & 2,25 & 2,22 & 2 & 1,97 & 1,81 & 1,62 & 1,48 & 1,5 & 1,46 \\
\hline $\mathrm{AM}$ & 1 & 0,69 & 0,67 & 0,56 & 0,45 & 0,37 & 0,33 & 0,19 & 0,13 & 0,24 & 0,27 & 0,19 & 0,15 & 0,22 \\
\hline $\mathrm{AP}$ & 0,05 & 0,05 & 0,28 & 0,28 & 0,23 & 0,11 & 0,11 & 0,1 & 0,04 & 0,11 & 0,18 & 0,12 & 0,18 & 0,26 \\
\hline $\mathrm{BA}$ & 1,64 & 1,71 & 1,82 & 1,63 & 1,42 & 1,17 & 1,02 & 0,82 & 0,72 & 0,63 & 0,52 & 0,46 & 0,49 & 0,47 \\
\hline $\mathrm{CE}$ & 0,87 & 0,94 & 1,18 & 1,06 & 0,92 & 0,73 & 0,6 & 0,38 & 0,24 & 0,17 & 0,28 & 0,29 & 0,28 & 0,29 \\
\hline $\mathrm{DF}$ & 0,36 & 0,35 & 0,4 & 0,36 & 0,28 & 0,35 & 0,33 & 0,19 & 0,16 & 0,17 & 0,18 & 0,16 & 0,1 & 0,16 \\
\hline ES & 0,98 & 0,83 & 1,16 & 1,02 & 0,73 & 0,44 & 0,34 & 0,19 & 0,1 & 0,08 & 0,17 & 0,14 & 0,15 & 0,21 \\
\hline GO & 3,13 & 2,81 & 2,77 & 2,4 & 2,21 & 1,85 & 1,82 & 1,61 & 1,4 & 1,28 & 1,3 & 1,01 & 1,02 & 0,92 \\
\hline MA & 2,58 & 2,1 & 2,73 & 2,22 & 1,74 & 1,33 & 1,15 & 0,91 & 0,74 & 0,68 & 0,64 & 0,47 & 0,41 & 0,38 \\
\hline MG & 1,41 & 2,34 & 2,63 & 2,43 & 2,24 & 2,03 & 1,89 & 1,88 & 1,76 & 1,79 & 1,82 & 1,82 & 1,75 & 1,83 \\
\hline MS & 3,1 & 2,94 & 3,1 & 2,67 & 2,33 & 2,01 & 1,81 & 1,48 & 1,15 & 1,15 & 1,2 & 1,13 & 1,05 & 1,02 \\
\hline MT & 2,5 & 1,97 & 1,59 & 1,76 & 1,3 & 1,11 & 1,1 & 0,94 & 0,7 & 0,54 & 0,55 & 0,4 & 0,3 & 0,35 \\
\hline PA & 0,57 & 0,63 & 0,67 & 0,61 & 0,6 & 0,46 & 0,44 & 0,35 & 0,28 & 0,24 & 0,29 & 0,19 & 0,11 & 0,1 \\
\hline PB & 1,53 & 1,1 & 1,42 & 1,17 & 1,08 & 0,89 & 0,76 & 0,6 & 0,48 & 0,34 & 0,36 & 0,25 & 0,26 & 0,27 \\
\hline $\mathrm{PE}$ & 0,86 & 1,12 & 1,25 & 1,17 & 1,04 & 0,83 & 0,67 & 0,53 & 0,42 & 0,43 & 0,38 & 0,39 & 0,46 & 0,53 \\
\hline PI & 1,73 & 1,74 & 1,64 & 1,52 & 1,42 & 1,09 & 0,85 & 0,78 & 0,6 & 0,6 & 0,54 & 0,57 & 0,5 & 0,59 \\
\hline PR & 1,29 & 1,34 & 1,24 & 1,05 & 1,08 & 1,29 & 1,26 & 1,16 & 1,19 & 1,12 & 0,89 & 0,76 & 0,6 & 0,6 \\
\hline RJ & 2,07 & 1,9 & 2,35 & 2,01 & 2,04 & 1,9 & 1,72 & 1,73 & 1,6 & 1,63 & 1,56 & 1,46 & 1,65 & 1,54 \\
\hline $\mathrm{RN}$ & 0,71 & 0,54 & 0,65 & 0,53 & 0,38 & 0,32 & 0,26 & 0,22 & 0,19 & 0,17 & 0,2 & 0,13 & 0,11 & 0,15 \\
\hline RO & 1,11 & 1,05 & 1,45 & 1,21 & 1,03 & 0,85 & 0,72 & 0,64 & 0,5 & 0,53 & 0,54 & 0,5 & 0,45 & 0,62 \\
\hline $\mathrm{RR}$ & 0,31 & 0,28 & 0,35 & 0,43 & 0,04 & 0,15 & 0,1 & $-0,13$ & $-0,13$ & 0,31 & 0,04 & $-0,1$ & 0,2 & 0,37 \\
\hline $\mathrm{RS}$ & 2,66 & 2,51 & 2,79 & 2,8 & 2,83 & 2,58 & 2,53 & 2,54 & 2,34 & 2,2 & 2,14 & 2,14 & 2,18 & 2,09 \\
\hline $\mathrm{SC}$ & 1,83 & 1,45 & 1,95 & 1,67 & 1,64 & 1,19 & 1,09 & 0,9 & 0,77 & 0,61 & 0,63 & 0,46 & 0,41 & 0,48 \\
\hline SE & 0,88 & 0,78 & 0,73 & 0,68 & 0,65 & 0,45 & 0,57 & 0,42 & 0,22 & 0,27 & 0,33 & 0,43 & 0,53 & 0,55 \\
\hline SP & 1,93 & 1,97 & 2,27 & 2,24 & 2,23 & 1,97 & 1,89 & 1,71 & 1,63 & 1,5 & 1,53 & 1,46 & 1,54 & 1,42 \\
\hline TO & 0,35 & 0,27 & 0,37 & 0,26 & 0,35 & 0,14 & 0,13 & 0,08 & 0,1 & 0,11 & 0,16 & 0,21 & 0,21 & 0,26 \\
\hline Tot & 1,7 & 1,73 & 1,95 & 1,83 & 1,74 & 1,53 & 1,43 & 1,3 & 1,19 & 1,13 & 1,12 & 1,04 & 1,05 & 1,05 \\
\hline
\end{tabular}

Fonte: http://www.tesouro.fazenda.gov.br/divida-consolidada-liquida (último acesso em 12 de outubro de 2010). A Secretaria do Tesouro Nacional esclarece que "todas as informações são coletadas e divulgadas por meio do Sistema de Coleta de Dados Contábeis dos Entes da Federação (SISTN), instituído em parceria com a Caixa Econômica Federal (CAIXA). Os procedimentos de coleta de dados e homologação encontram-se definidos na Portaria STN n ${ }^{\circ}$ 109/2002." 
Gráfico 2: Superávit Primário e Metas de Superávit: 1991-2013

\begin{tabular}{|c|c|c|c|}
\hline & $\begin{array}{l}\text { Superávit Primário } \\
(\% \mathrm{PIB})\end{array}$ & $\begin{array}{l}\text { Meta de } \\
\text { Superávit }\end{array}$ & $\begin{array}{l}\text { Meta (com as } \\
\text { reduções) }\end{array}$ \\
\hline 1991 & 2,71 & & \\
\hline 1992 & 1,57 & & \\
\hline 1993 & 2,26 & & \\
\hline 1994 & 5,21 & & \\
\hline 1995 & 0,25 & & \\
\hline 1996 & $-0,09$ & & \\
\hline 1997 & $-0,92$ & & \\
\hline 1998 & 0,01 & & \\
\hline 1999 & 2,93 & 2,7 & 2,7 \\
\hline 2000 & 3,22 & 2,6 & 2,6 \\
\hline 2001 & 3,35 & 3,5 & 3,5 \\
\hline 2002 & 3,55 & 3,75 & 3,75 \\
\hline 2003 & 3,89 & 4,25 & 4,25 \\
\hline 2004 & 4,18 & 4,25 & 4,25 \\
\hline 2005 & 4,35 & 4,25 & 4,25 \\
\hline 2006 & 3,86 & 4,25 & 4,25 \\
\hline 2007 & 3,31 & 3,8 & 3,8 \\
\hline 2008 & 3,42 & 2,5 & 2,5 \\
\hline 2009 & 2,03 & 3,1 & 3,1 \\
\hline 2010 & 2,77 & 3 & 3 \\
\hline 2011 & 3,11 & 3,1 & 3,1 \\
\hline 2012 & 2,38 & 3,1 & 3,1 \\
\hline 2013 & 1,89 & 3,1 & 3,1 \\
\hline
\end{tabular}

Fonte: Para os dados do superávit primário entre 1991 e 2007 a pesquisa se utilizou dos dados apresentados por Giambiagi (2008, pp. 542-543). Para os dados do superávit primário entre 2008 e 2013, a pesquisa se utilizou dos dados disponibilizados pelo Banco Central no documento Indicadores Fiscais (BRASIL, 2014a, p. 6). As metas de superávit com as reduções foram retiradas das LDOs. 
Gráfico 3: Exceções ao cálculo do superávit em bilhões de reais

\begin{tabular}{|l|r|r|}
\hline & & \multicolumn{2}{|c|}{$\begin{array}{c}\text { Reduções (em R\$ } \\
\text { LDO }\end{array}$} & \% PIB \\
\hline 2006 & 0,2 & 3 \\
\hline 2007 & 0,49 & 11,283 \\
\hline 2008 & 0,49 & 13,825 \\
\hline 2009 & 0,84 & 28,5 \\
\hline 2010 & 0,5 & 29,8 \\
\hline 2011 & 0,68 & 32 \\
\hline 2012 & 0,87 & 40,6 \\
\hline 2013 & 1,25 & 65,2 \\
\hline
\end{tabular}

Fonte: LDOs de 2006 a 2013. As LDOs têm dispositivo que prevê: "o superávit será reduzido em até (valor) para atendimento de programação constante desta Lei”.

Gráfico 4: Dívida externa líquida do setor público em milhões de reais

\begin{tabular}{|r|r|}
\hline & \multicolumn{2}{|l|}{$\begin{array}{l}\text { Lívida Externa } \\
\text { Líquida }\end{array}$} \\
\hline 1991 & 36 \\
\hline 1992 & 342 \\
\hline 1993 & 7.754 \\
\hline 1994 & 44.357 \\
\hline 1995 & 38.132 \\
\hline 1996 & 31.593 \\
\hline 1997 & 38.580 \\
\hline 1998 & 57.177 \\
\hline 1999 & 108.769 \\
\hline 2000 & 111.322 \\
\hline 2001 & 125.162 \\
\hline 2002 & 231.744 \\
\hline 2003 & 189.728 \\
\hline 2004 & 153.229 \\
\hline 2005 & 67.906 \\
\hline 2006 & -27.816 \\
\hline 2007 & -198.360 \\
\hline 2008 & -332.440 \\
\hline 2009 & -292.532 \\
\hline 2010 & -359.692 \\
\hline 2011 & -538.468 \\
\hline 2012 & -619.419 \\
\hline 2013 & -714.676 \\
\hline & \\
\hline
\end{tabular}


Fonte: Secretaria do Tesouro Nacional. Mensurado a partir do dia 1/12 de cada um dos anos, a partir da série histórica disponibilizada pela Secretaria. Segundo a Secretaria do Tesouro Nacional: “A Dívida Externa Líquida do Setor Público refere-se ao total das obrigações externas do setor público não financeiro, deduzido dos seus ativos financeiros, junto aos agentes privados não financeiros e aos agentes financeiros, públicos e privados. Os saldos dos componentes da dívida externa líquida são apurados por competência, ou seja, pela apropriação mensal ao estoque do período anterior dos encargos relativos a cada obrigação ou haver, deduzidos eventuais pagamentos/recebimentos." E, ainda: "Os indicadores da dívida externa líquida do setor público abrangem as administrações diretas e indiretas nos níveis federal, estadual e municipal, bem como suas respectivas empresas estatais não-financeiras. Também integram a dívida externa líquida os saldos dos fundos públicos de natureza nãofinanceira, do regime geral de previdência social (RGPS) e das contas da autoridade monetária. Todos os valores são obtidos a partir dos balanços das instituições financeiras." 191 